$$
\begin{aligned}
& \text { الهمــزة واستعمـالاتهــا } \\
& \text { في الــتراث اللخـــوي } \\
& \text { "دراسة تحليلية لغوية" }
\end{aligned}
$$

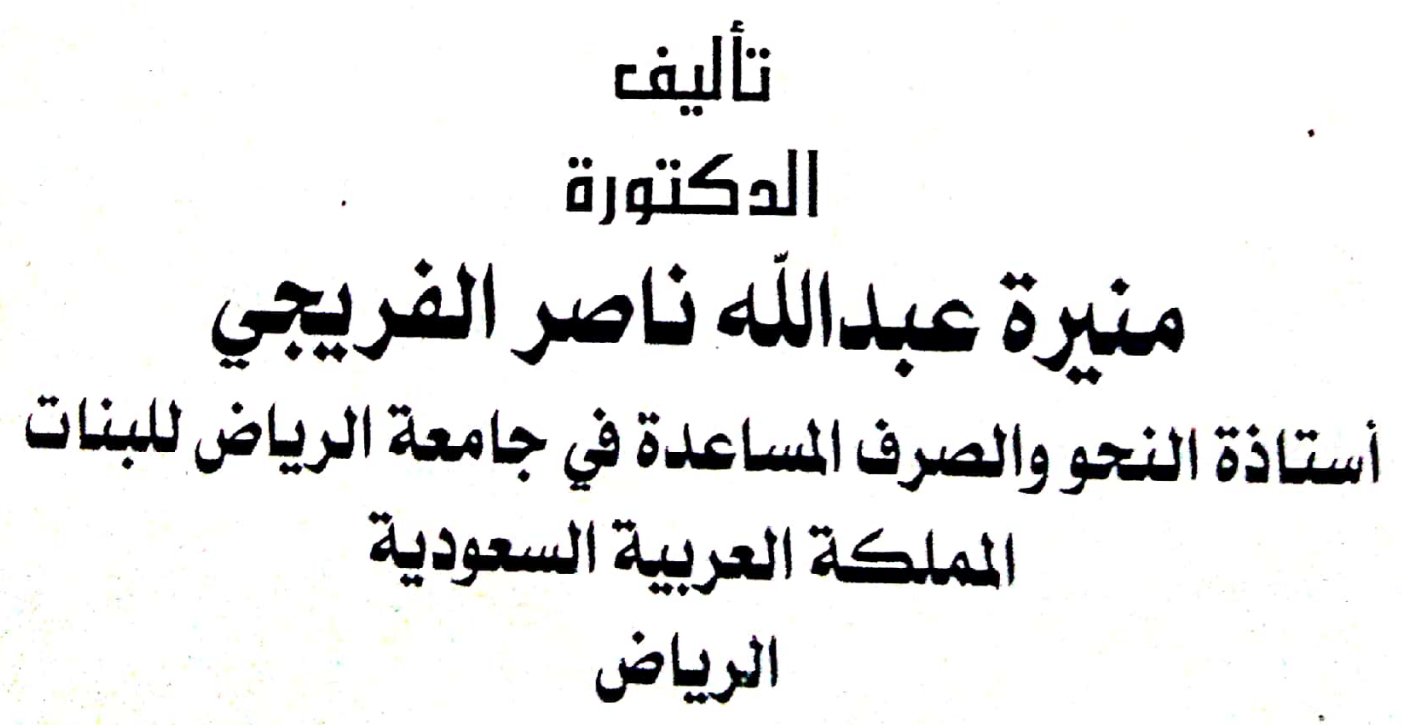




\section{الهمـزةز واستعمـالاتهـا}

\section{في الستراث اللغــوي}

\section{"دراسة تحليلية لغوية" فية"}

د/ منيرة عبدالله ناصر الفريجي

أستاذة النحو والصرف المساعدة في جامعة الرياض للبنات

$$
\text { المملكة العربية السعودية - الرياض ولف }
$$

مقدمة : مقدة

الحمد له وحده، والصلاة و السلام على من لا نبي بعده، سيدنا محمد بن

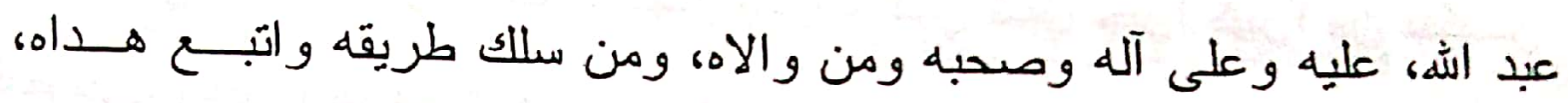
أفضل سلام و أنتم صلاة، وبعد:

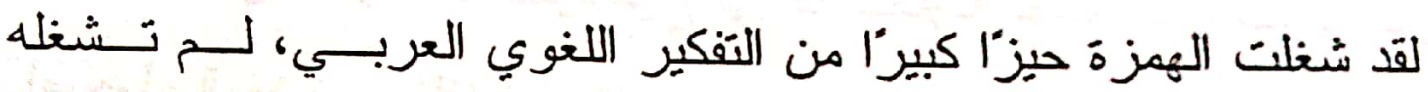
غير ها من الحروف والأدوات العربية، ودار حولها خلاف كبير بين النحــوبين و القزاء، وتعددت اسنعمالاتها ودلالاتها، كما تعددت صور ها التي وردت عليها، فطور"ا تكون أصلية، و آخر تكون زائدة، واستعملت محققة مرة، وبالتسهيل مرة أخرى، وتجاوز العرب فيها فحذقوها أحيانا، و أبدلو ها من غيرها أحيانًا أخرى،

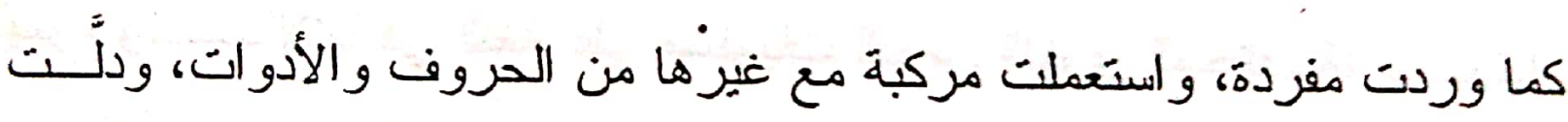
على العديذ من المعاني و الوظائف النحوية في حال إفرادها أو نزكبها؛ بل تعدد رنسميا الإملائي حسب الموضع الأي تزد فيها في بنية الكلمة العربيــة منقدمسة ومنتونسطة ومتأخرة. 


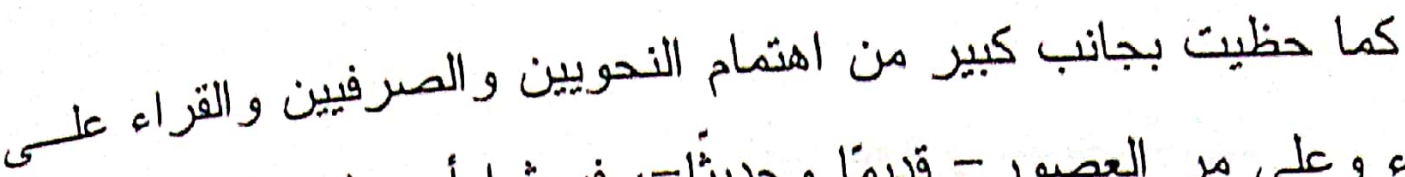

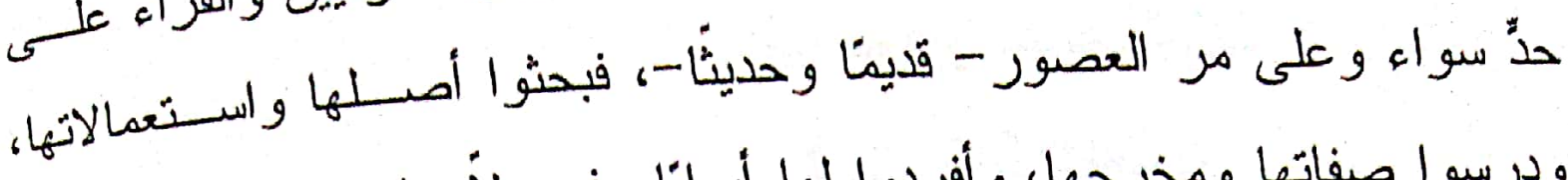
ودرسو ا صفاتها ومخرجها، و أفردوا لها أبو ابتا وفصو لأ خاصنة فــي مؤلفسانهم النحوية والصرفية، على نحو ما فعل ابن هشام في المغني، ونظرْا لهذا السـور الذي شغلته الهمزة في الدرس اللغوي، وما تثميز به من خصائص فقد عتـدت العزم على كتابة هذا البحث، لبيان بعـض المسـكلات التـي نــدور حولهــا، و اختلافات النحويين فيها.

وقد دفعني لاختيار هذا الموضوع و الكتابة فيه إلى جانب ذلــك كلــه، الرغبة في ثقديم صورة منكاملة لهذا الحرف الذي شغل حيز"ا كبير"ا من تفكيــر اللغويين، وكثز الخلاف النحوي حوله.

وتكمن أهمية هذا الموضوع في أنه محاولة جادة للمّ شتات ما تقرق من

آر اء حول الهززة، ومناقشتها وتثديم صورة و اضحة لما دار حولها من خلاف.

فعلى الرغم مما قدم من در اسات حول الهمزة قديمًا وحديثًا، إلا أن هذه

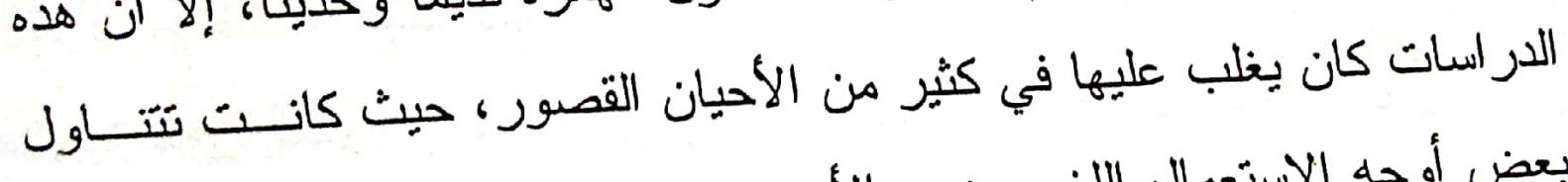

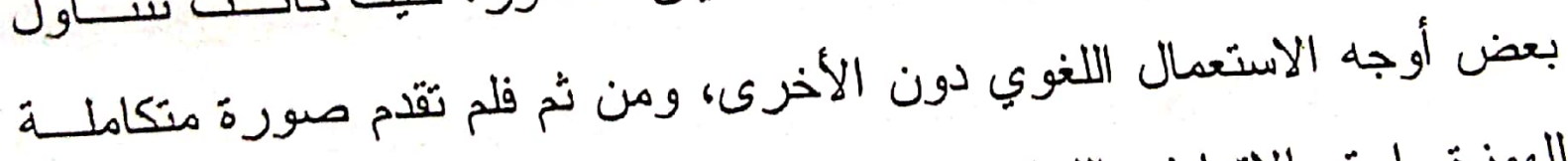

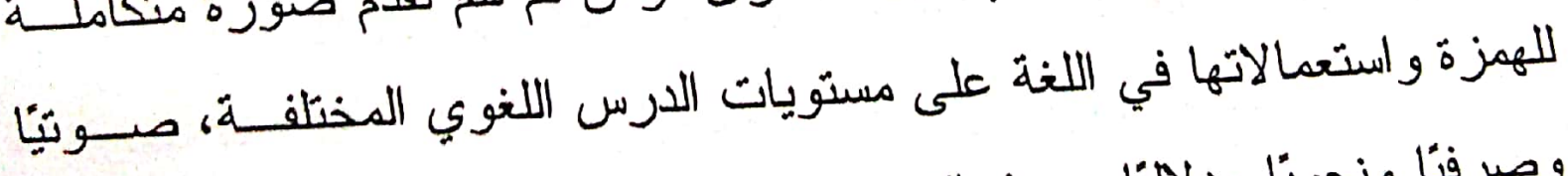

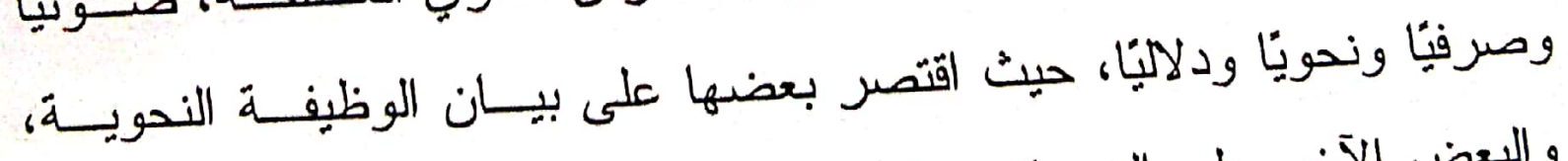
و البعض الآخر على الخصائص الصوثية، وركز بعضها على الرسم الإملاني،

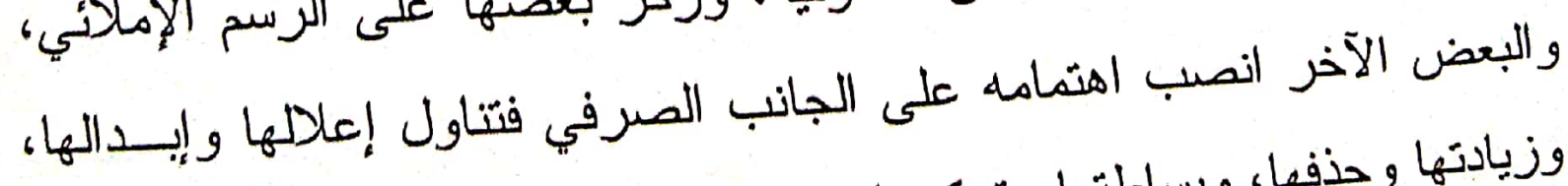
وزيادتها وحذفها، وبساطنها ونزكيبها... ونحو ذلك. 
وقد فسمت مادة هذا البحث : مقدمة، وتشئيد، ومبحثن، وخاتثة المتملت

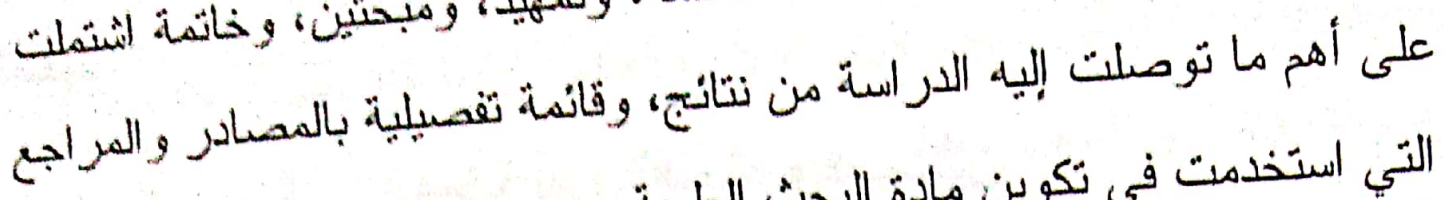
التي استخدمت في تكوين مادة البحث العلمية.

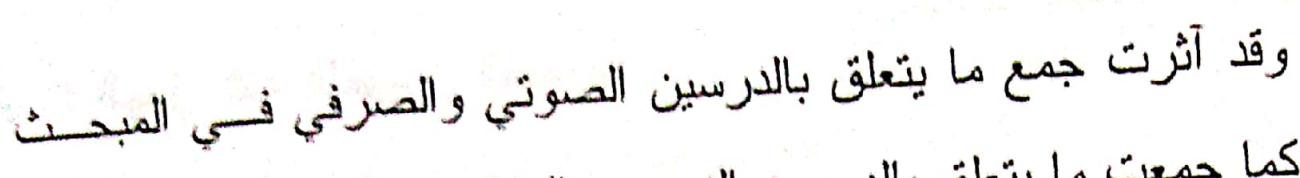

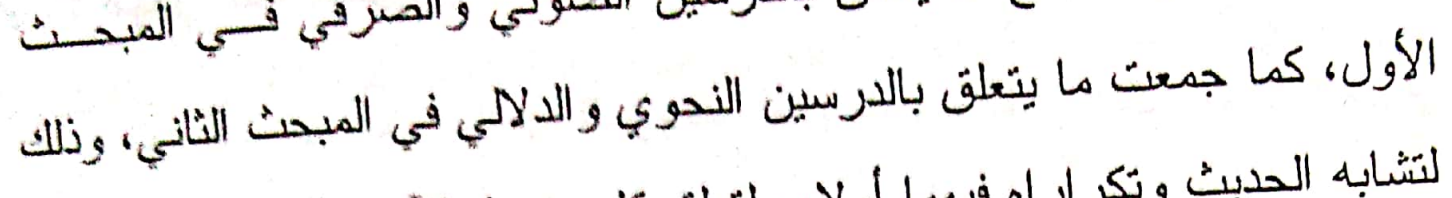

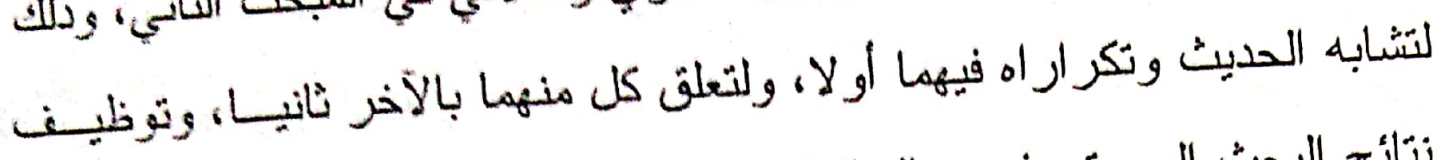

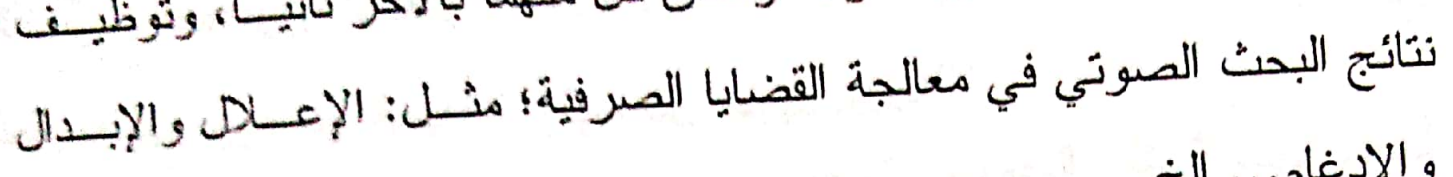
و الإدغام... (إلخ.

و الله تعالى أسأل أن يجعل في هذا العمل النفع و الفائدة وأن بجعله خالصنا لوجهه الكريم، وما توفيقي إلا باله عليه نوكلت و إليه أنيب. 


\section{الهمزة بين القدماء و المحدثين}

\section{أولا: الهمز عند اللغويين القدماء:}

توصف الهمزة بأنها من الحروف الشديدة، وقد لمس ذلك علماء اللغـــة

القدامى و المحدثون(")، فقالوا: " إنها نبرة تخرج من أقصى الحلق، وتفتقر فـي تحقيقها إلى شيء من الجهذ(r)، ولهذا ثقل عليهم نطقه"(r).

ويكاد يتقق اللغويون القدامى على أن الهززة حرف شديد مجهور ، بخرج

من أول مخارج الحلق (من آخر الحلق) مما يلي الصدر (๕). فقا نقل ابن منظور عن الخليل قوله: "الهمزة صوت مهنوت في أقصى الحلق يصبر همزة، فإذا رفه عن الهمز، كان نفسًا يحول إلى مخرج الهاء، فلذلك استخفت العرب إدخال الهاء على الألف المقطو عة نحو أر اق وهراق...."(•).

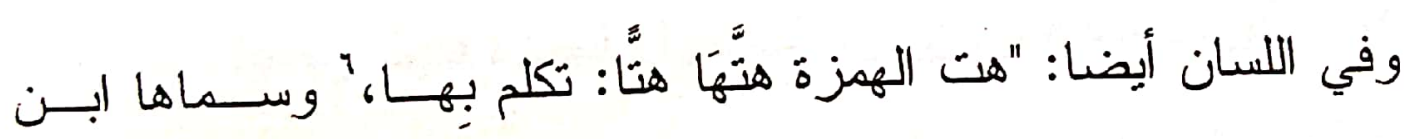
الجزري الحرف المهنوف، حيث قال: "سميت بذلك لخروجهــا مــن الـصدر

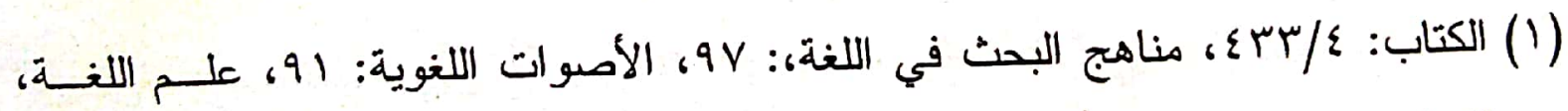

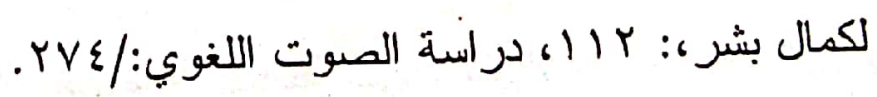
( ) ( الكتاب:

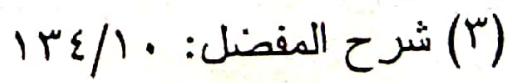
ع

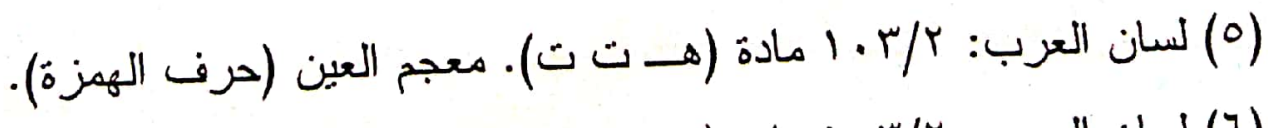

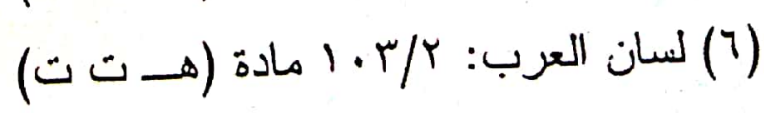




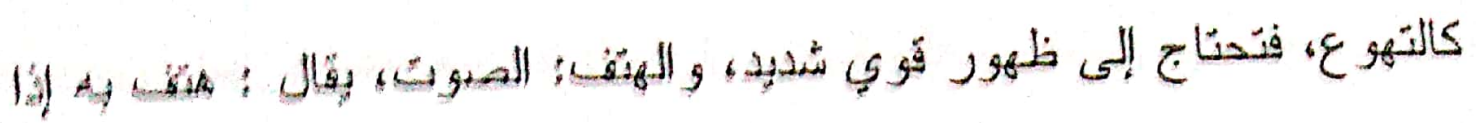

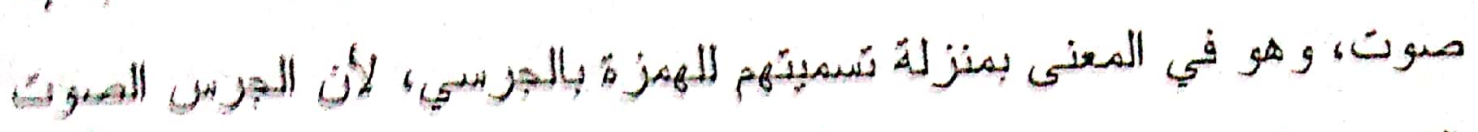
الشُديد، و اللهنف: الصوت الثشديد" (1)

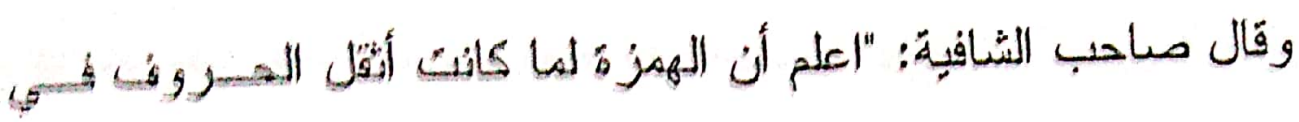

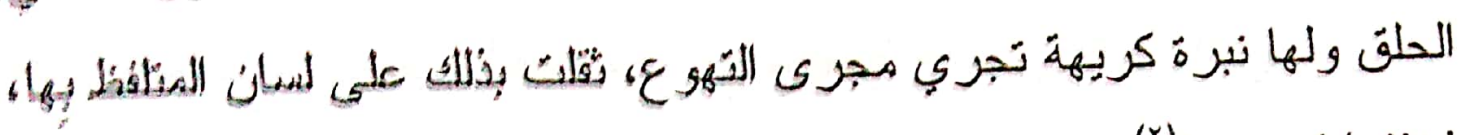

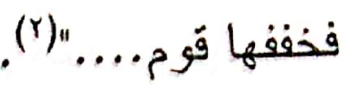
تثانيا: الههزة عند اللغويين المحدثين:

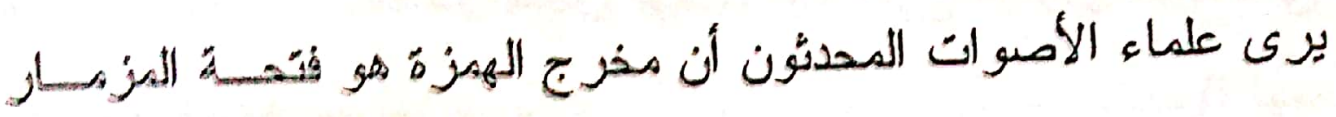
الني تنطبق عند النطق بها، ثم تنفتح فجأة فتصدر الههزة الدحتقة (").

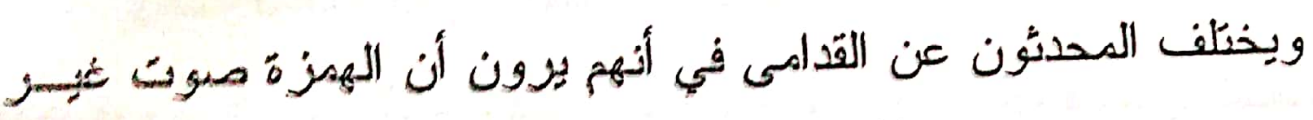

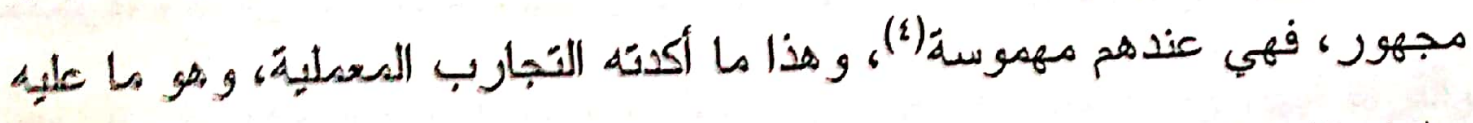
علماء اللغة الغربيون، وإن اختلفت تعبيز اتهم في وصفيه. ويمكن إرجاع الخلاف بين المتقدمين و المتأخرين في وصف الئززة اللى

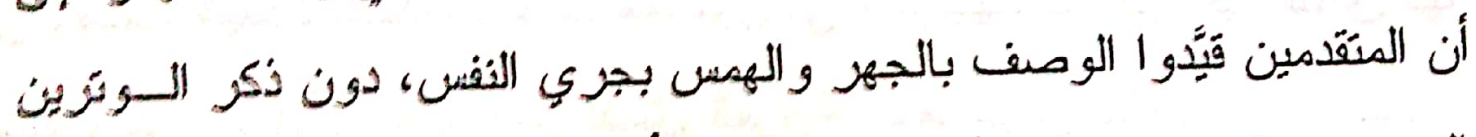

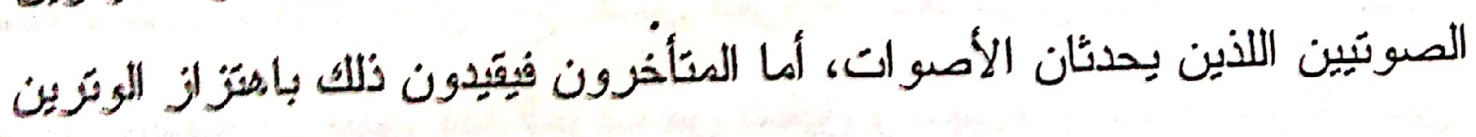

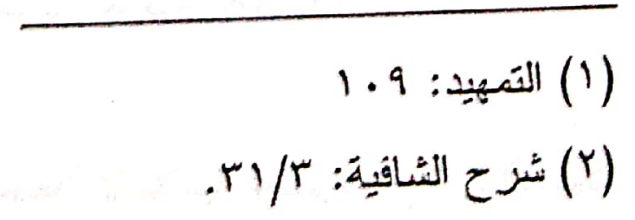

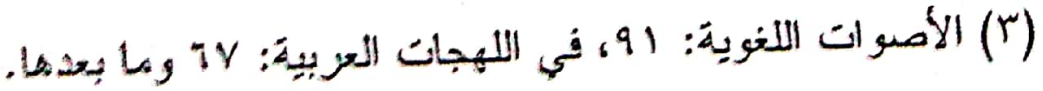

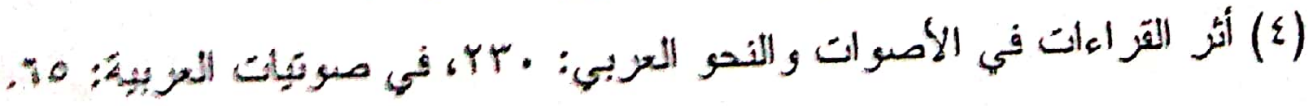


الصوتيين و استرخائهما، فما اهتز الوثران عند حدوثه من الأصسـوات وصــف

بالجهر ، وما لم بهتز وصف بالهمس (1).

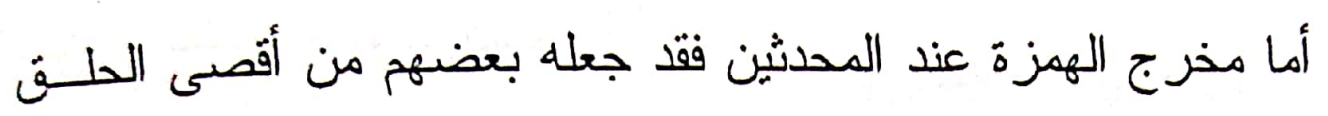

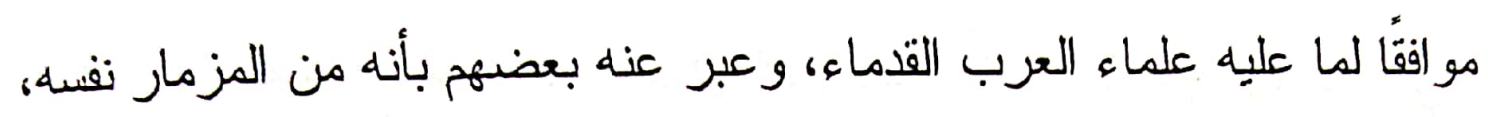
وذهب بعضهم إلى أنه من الحنجرة، وهي موضع انحباس النفس الذي يحدثها،

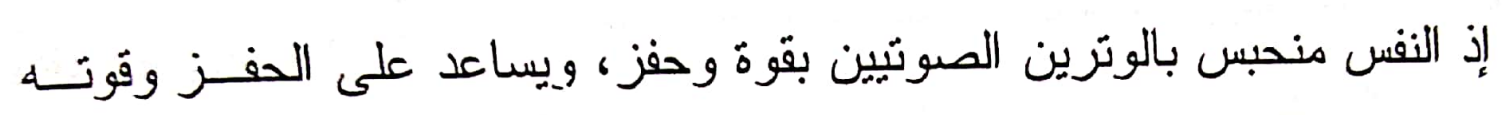

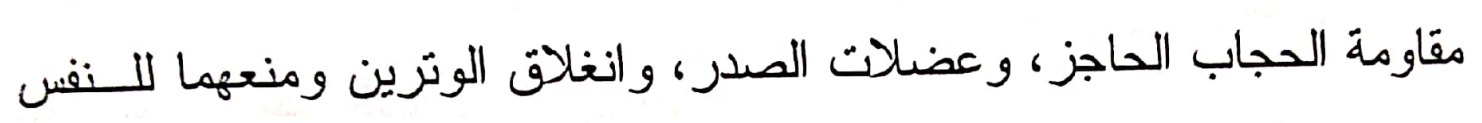

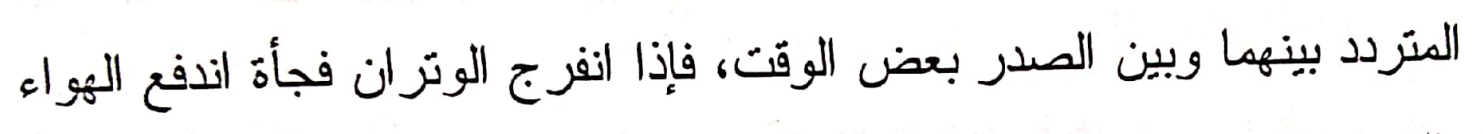
بالصوت، وسمع صوتها شديدًا قويًا (Y). ولذلك فعلماء الغرب المحدثون بسمونها الوقفة الحنجرية أعلى الحنجرة، و الحلق عند القدماء يشمل الحنجرة، و عليه فلا خلاف بين القدماء و المحدثين في وصف مخرج الهمزة (r).

ومن خلال ما سبق ينبين أن علماء الصوتيات القدامى و المحثين منفقون في وصف الهمزة بالثدة، ولكنهم مختلفون في مخرجها، لذا كان في النطق بها

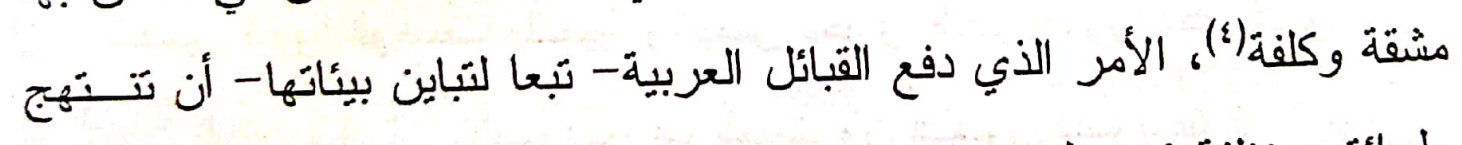
طرائق مختلفة في نطق هذا الحرف من تحقيق وتسهيل، أو جعله بمنزلة بـينين

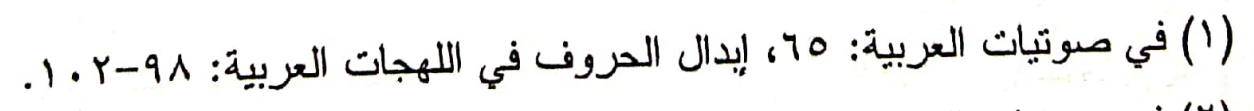

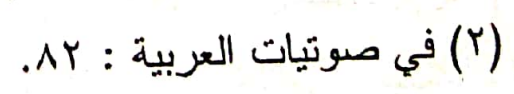

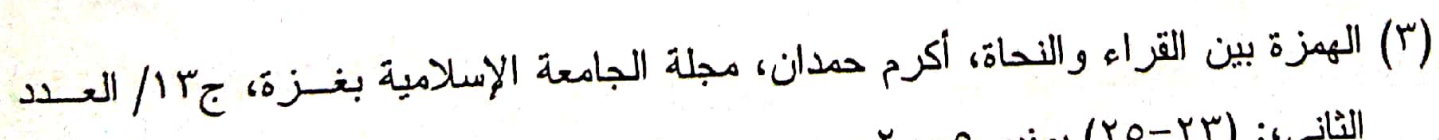

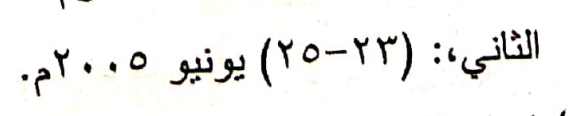

(؛) إيراز المعاني: ؟ 9. 
التُقثيق و التنسينيل (بين بين)، أو التصرف فيه بإنباته أو حذفه، أو إبـدالا مسن

ويمكن القول إن المهزة قَد وردت في الارس اللغوي على صور شنى،

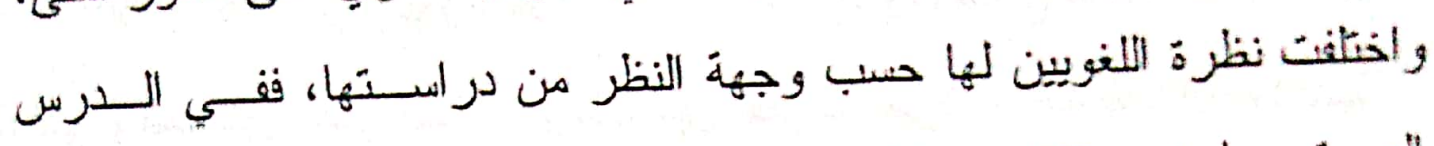

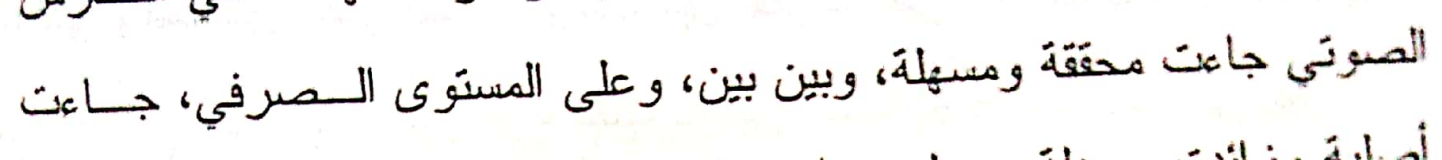

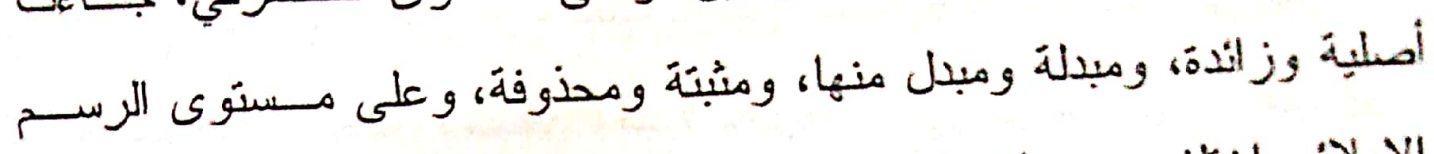

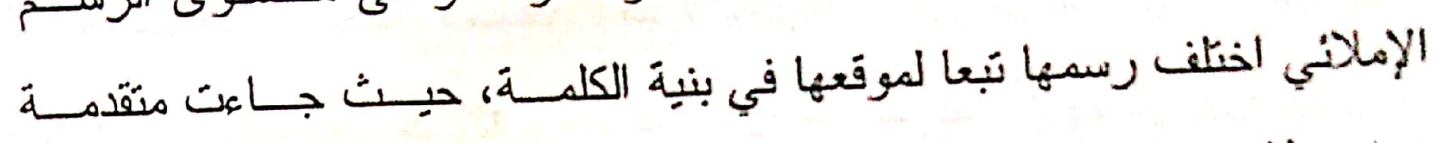
ومتوسطة ومنطرفة، وتبعاً للحركة التي تحملها وحركة ما قبلها من حروف كان

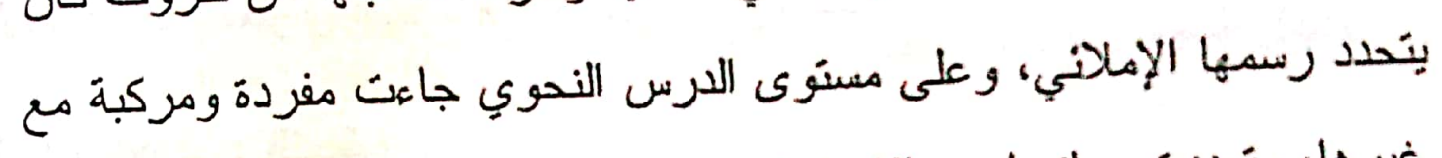
غير ها، وتعددت معانيها بين الاستقهام، و النداء، و التسوية،..... و غير ذلك. وفي المباحث الآتيةَ نتتاول بعض هذه الحالات، ونبين أراء النحـــيين

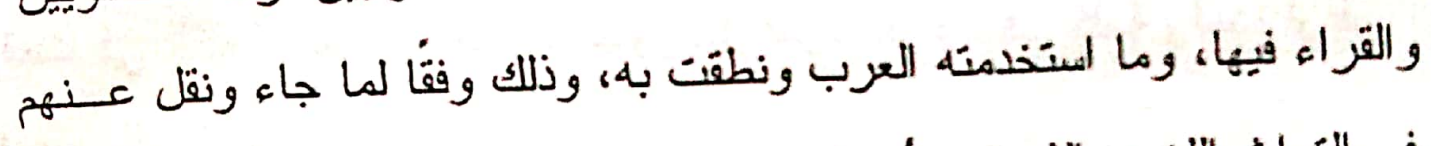
في التزات اللغوي الذي بين أيدينا. 


\section{المبحث الأول}

\section{استعمالات الهمزة في الارس الصوتي والصرفي}

نببق القول إن الهمزة حرف بعيد المخرج؛ والإجماع منعقد عند العلداه.

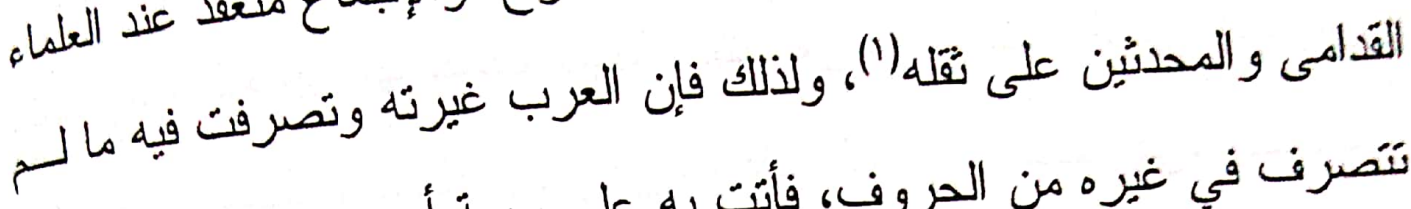
تنصرف في غيره من الحروف، فأتت به على سبعة أوجه مستعملة في القزآن

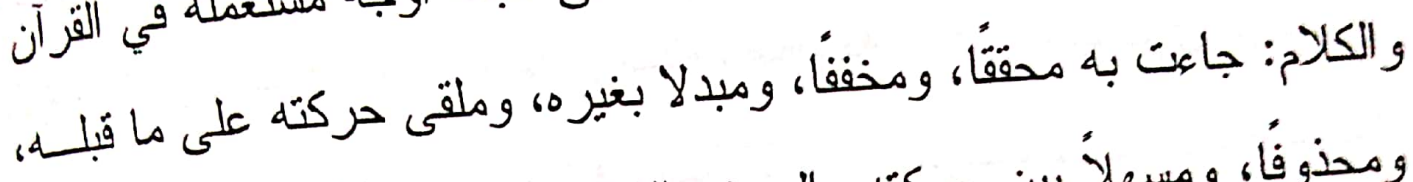

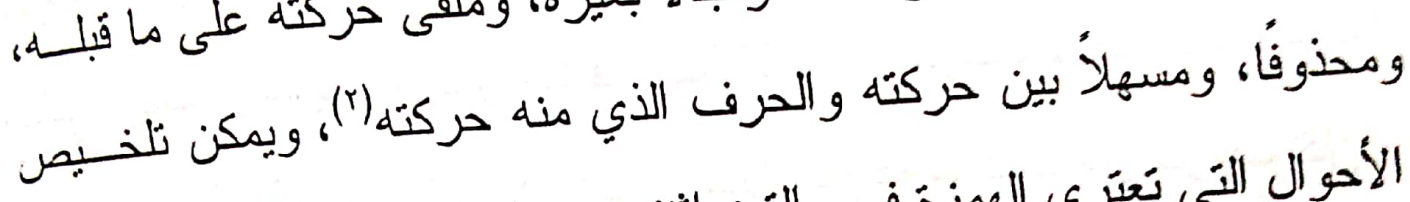

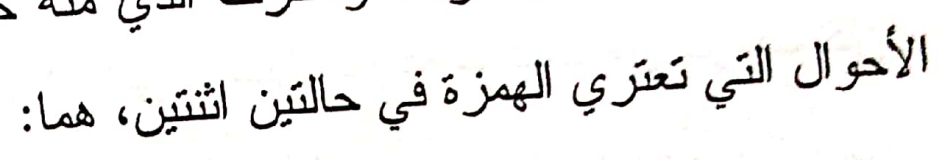
الحالة الأولى: التحقيق:

وهو إخر اج الهمزة بكل صفاتها من مخرجها من أقصى الحلق أينمسا

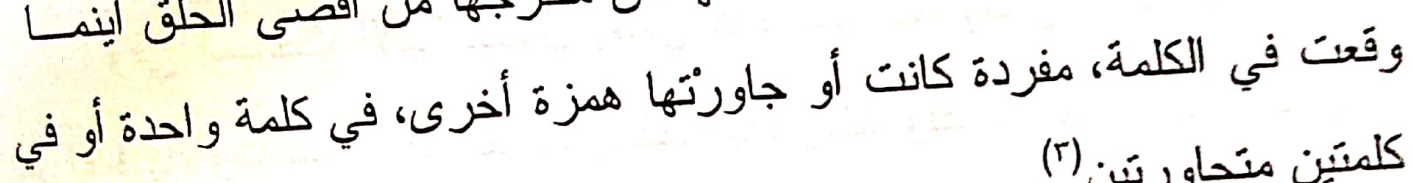
كلمنَن منتجاورتين (r). الحالة الثانية:ة التسهيل:

بِقصد بالتسهيل التخفيف، أي تخفيف النطق بالهمزة، ومن صوره ما يلي:

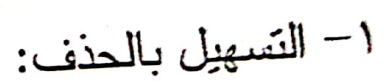

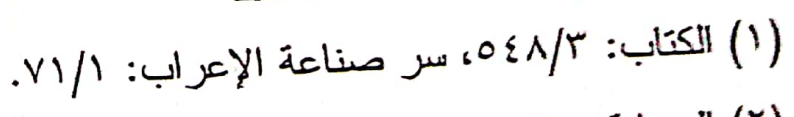

$$
\begin{aligned}
& \text { (Y) الترعايَة: }
\end{aligned}
$$

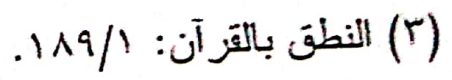




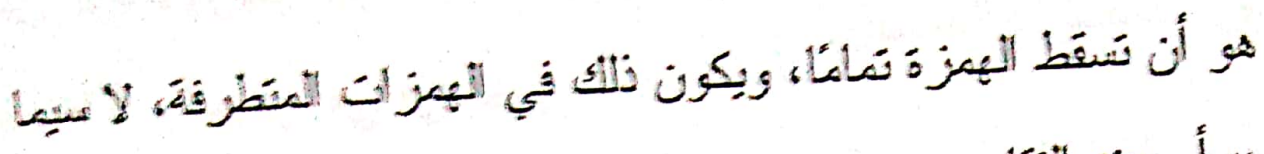

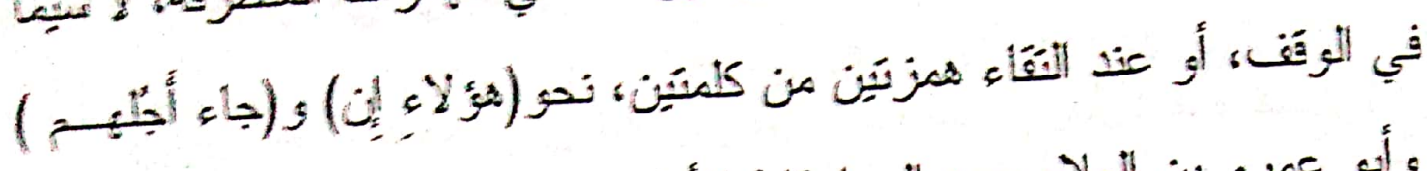

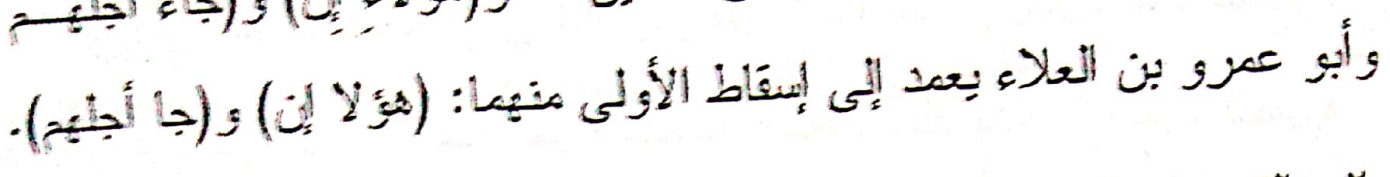

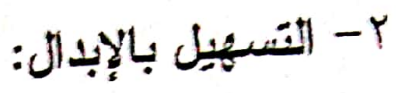

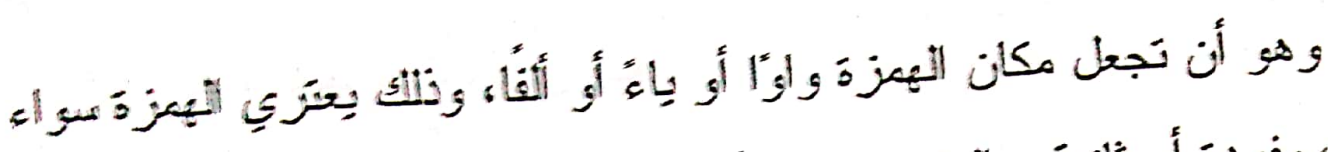

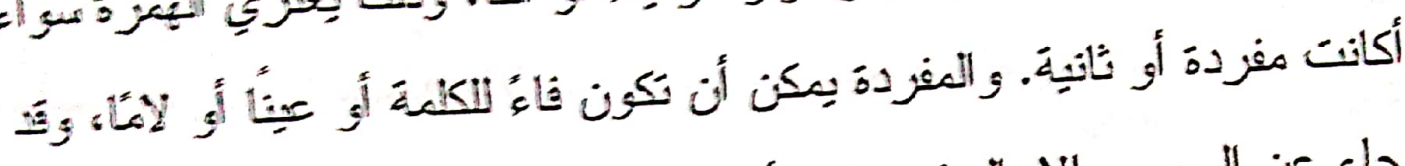

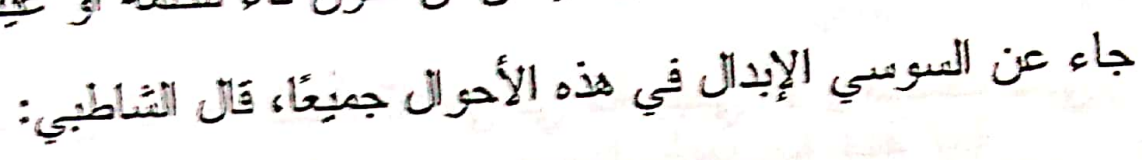

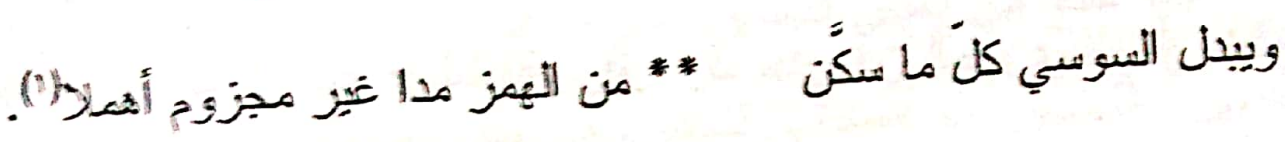

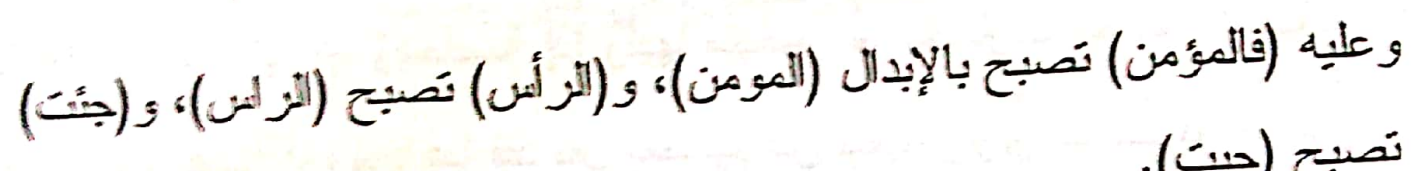
تصبح (جيت)).

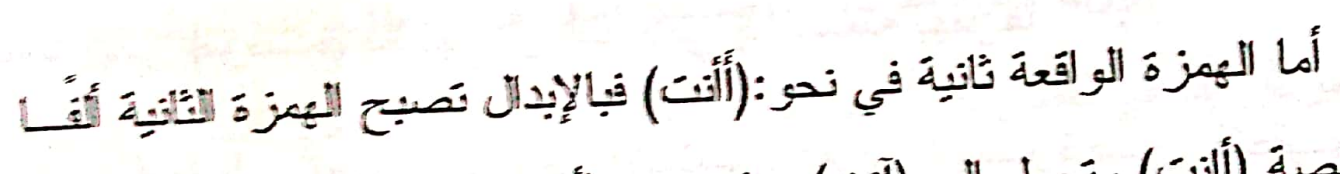

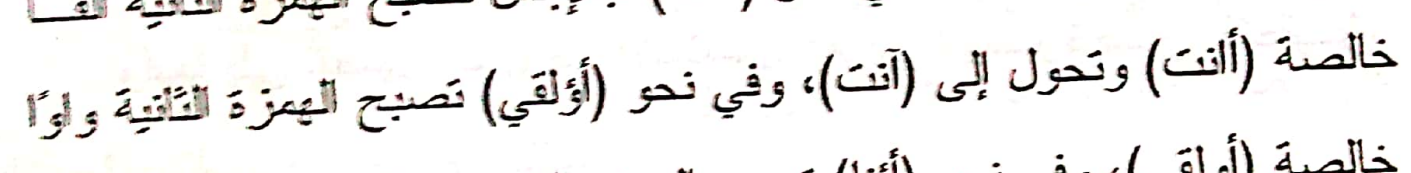

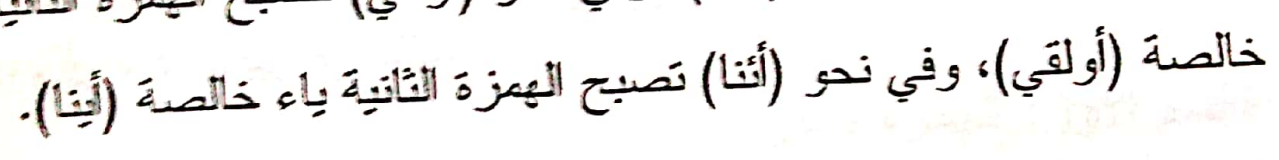
r- التسهيل بين بين:

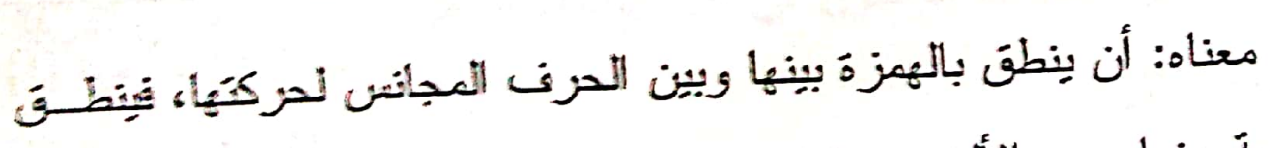

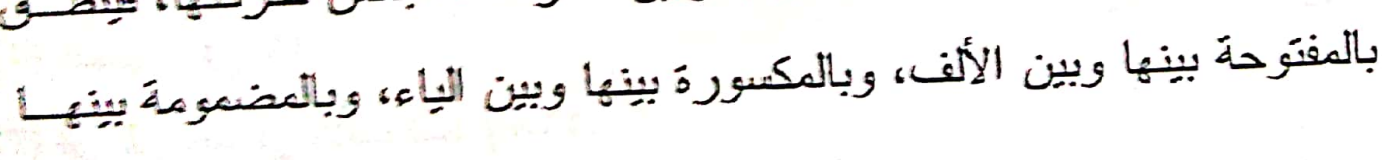

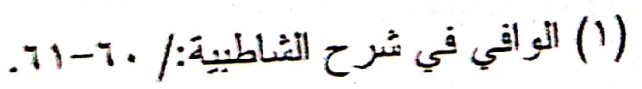




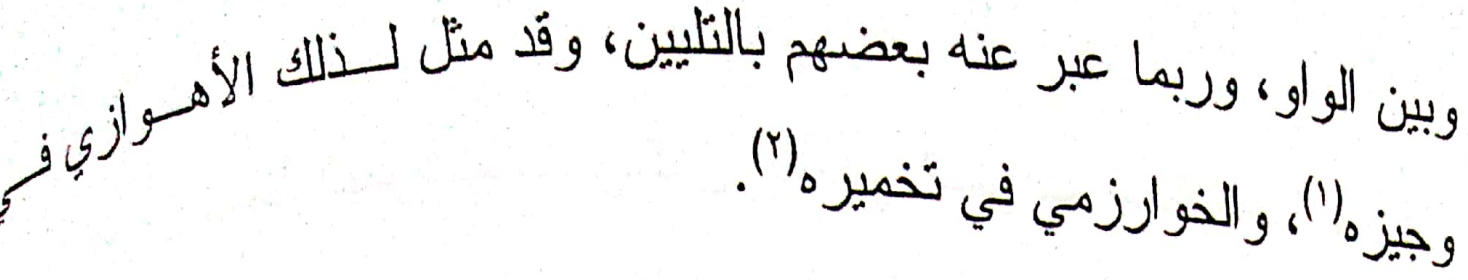

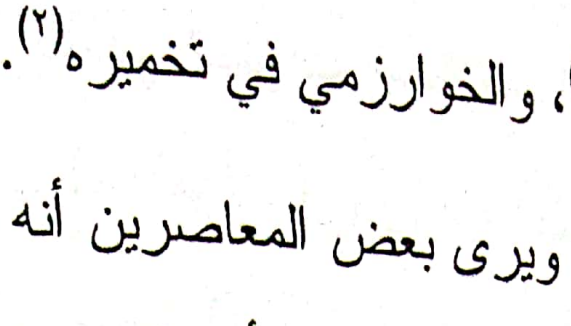
فسهلة، أو هذه بين بين، أو هذه همزة المعاصرين أنه ليس من الصواب أن بقال: هذاه هـهزة في هذه الحالات؛ لأن وضع الحنجرة لدى النطق بهذه الحالات بتنغبر إلى وضع آخر غبر وضع الهمزة(r)، ويرى البعض أنه لا غضاضة في النسسمية، فسان وصفهم الهمزة بأنَّا مسهلة مثلا خروج بها عن الهمزة الأصلية(؟). ولا خلاف بين القراء و النحاة القدامى في أنه ينبغي ألا بنعسف في إخراجها، بل يجب أن تخرج بلطافة ورفق، وقد حذر ابن الجزري من أن بنطن

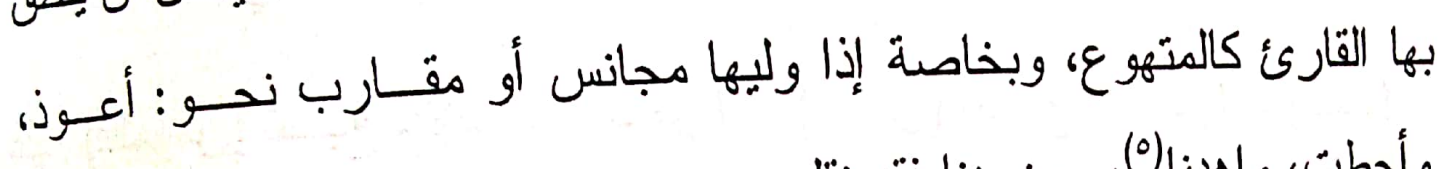

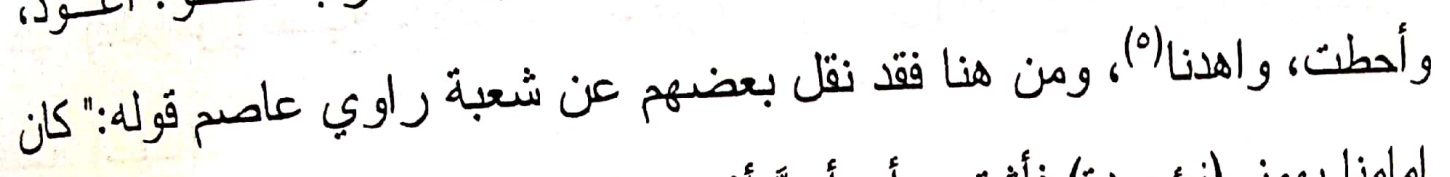

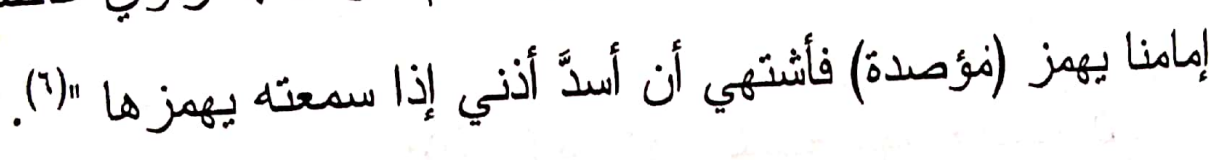

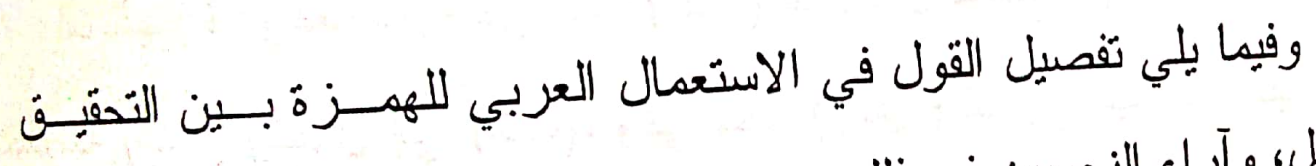

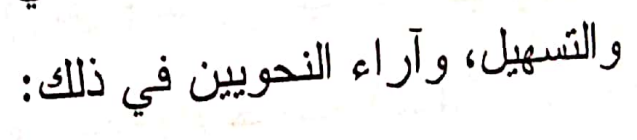

$$
\begin{aligned}
& \text { (1) الوجيز: الوح-quو } \\
& \text { (r) }
\end{aligned}
$$

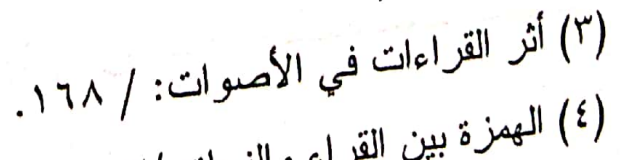

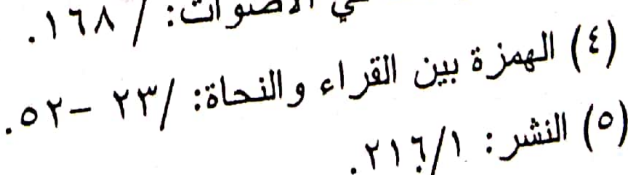

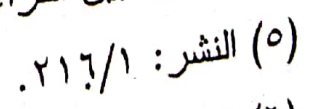

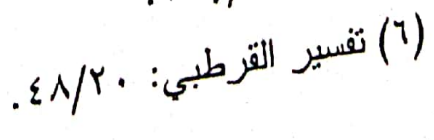




\section{الهمزة بين التحقيق و التسهيل:}

سبق القول إن القبائل العربية كان لها في نطق الهمزة مــهبان: الأول

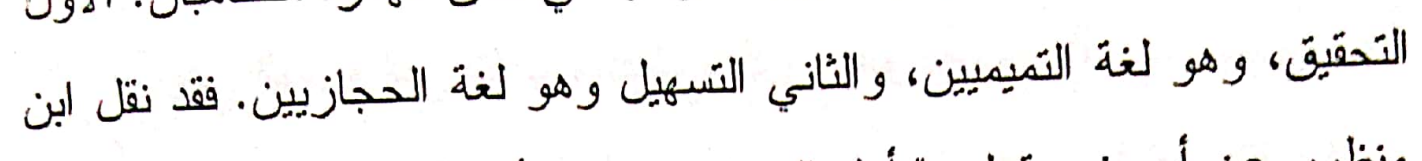

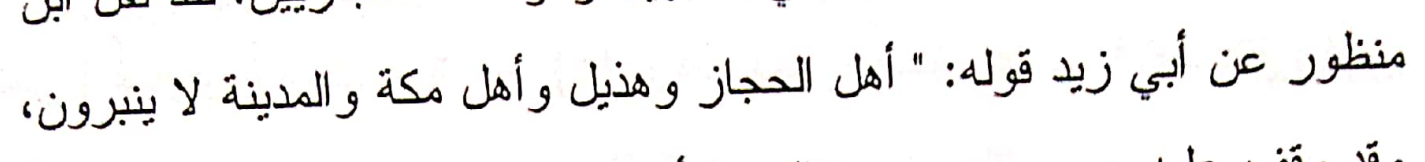

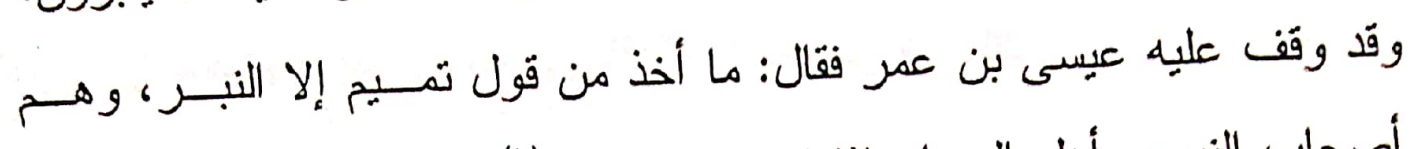

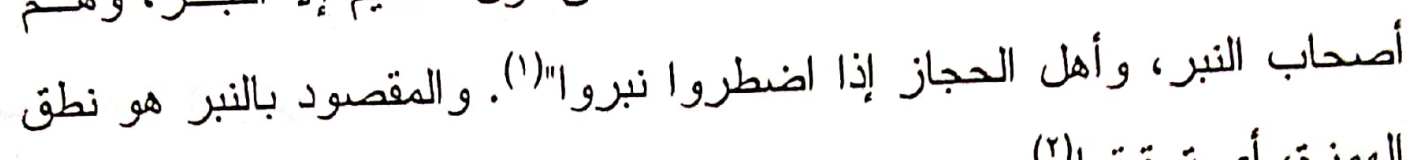
الهمزة، أي تحقيقها(").

كما حدد ابن يعيش التحقيق (النبر) و التخفيــف (التسعهيل) فـذكر أن

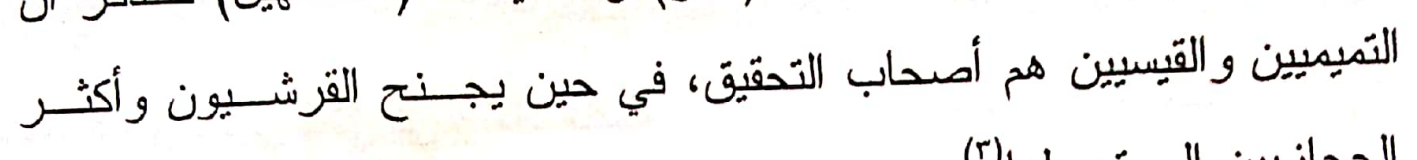
الحجازيين إلى تسهيلها (r).

وقَد تكون الهمزة مفردة، أو مجتمعة مع غيرها، وفي هذه الحالة تكــون

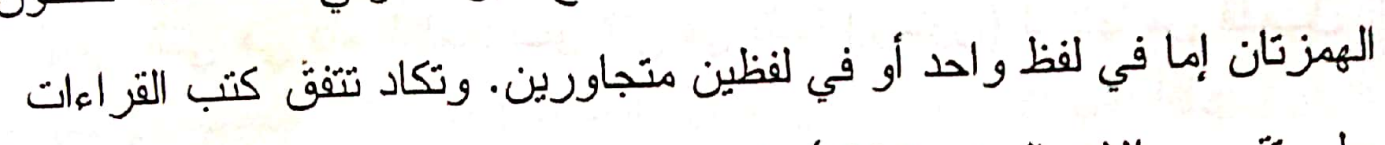

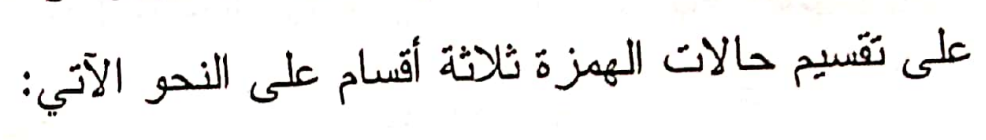

\section{القسم الأول: الهمزة المفردة:}

و الهمزة المفردة قد نكون في أول الكلمة، أو في وسطها، أو في آخرها على النحو الآتي: - ملي

$$
\begin{aligned}
& \text { (1) لسان العرب: }
\end{aligned}
$$

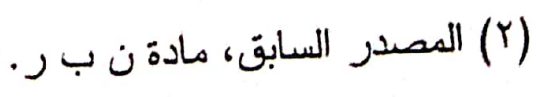

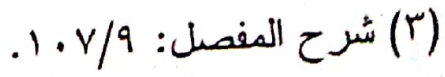




\section{أولا: المهزة التي تأتي في أول الكلمة نوعان كما يلي:

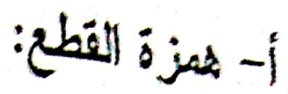

وهي اليهزة التي تكتب وتلفظ، وتكون مفتوحة نحو (أَخذ)، ومضومة

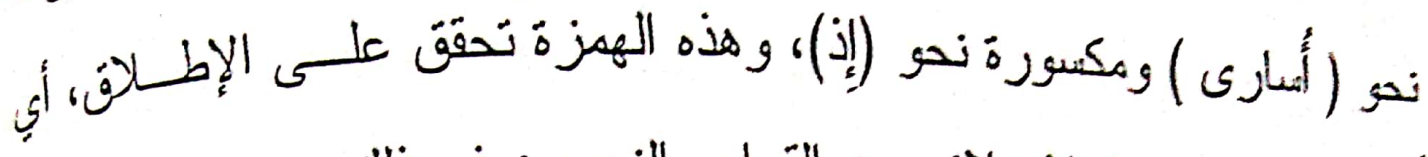

نُنزرج من مخرجها بلا خلاف بين القراء و النحويين في ذللك.

ب- ثمزة اللوصل:

وهي الهمزة التي تسقط في درج الكلام، وتحقق لـدى الابتــداء بهـا،

وتسنتخم توصلاً للنطق بالساكن بعدها.

ثانيا: العهزة التي تأئي في وسط الكلمة:

وهذه اللهزة قَّ تككن فاء الكلمة، أو عينها، أو لامها، على النحو الآتي:

أ-فاللهزة التي هي.فاء الكلمة: نحو التي في كلمة (يؤمنون) إذ إنها من الفهـل

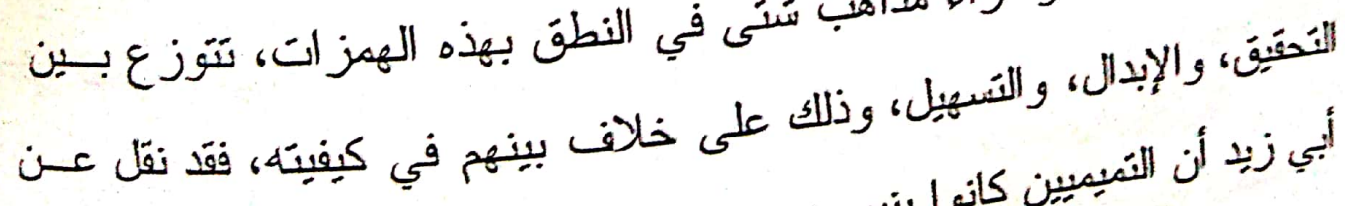

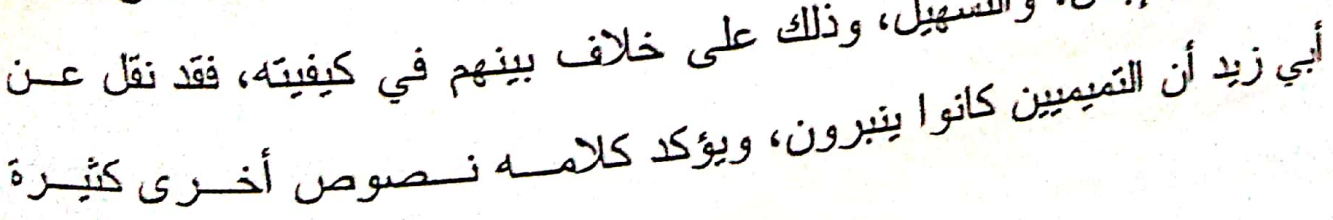


عرضت لألفاظ مفردة، منها ما ذكره يونس من أن الحجازيين يقولون (جونسـة) بلا همز، وبني تميحم تهمز فنتقول (جؤنة) (1). ونتل أبو عمرو بن العلاء أن أهل الحجاز لا ينبرون (رؤيا)، والتميميُّون يحققونها(').

كما ورد عن أبي جعفر النحاس قوله: "لغة الحجـازيين (جبريـلـ)، ولغــة التميميين (جبر ائيل) (r).

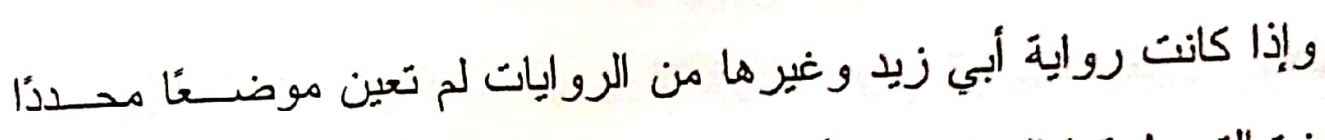

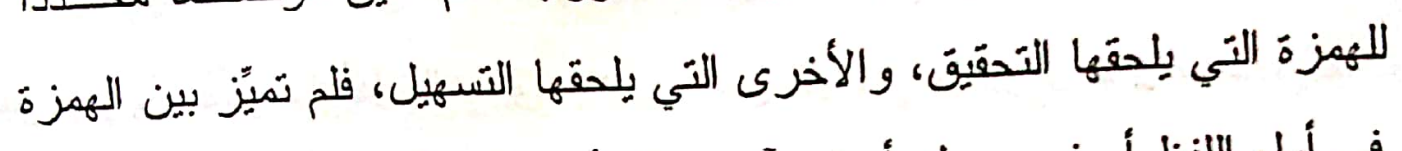

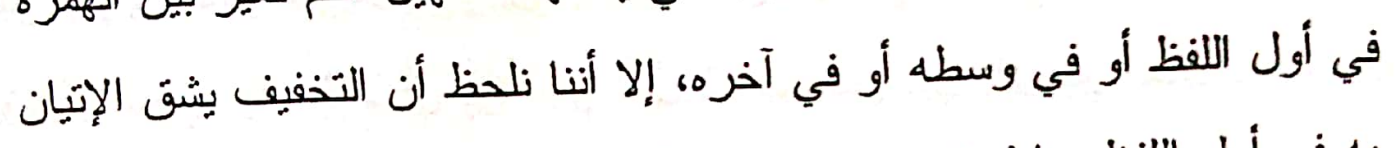

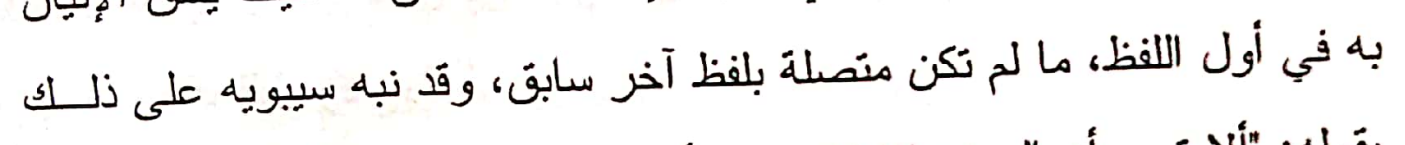

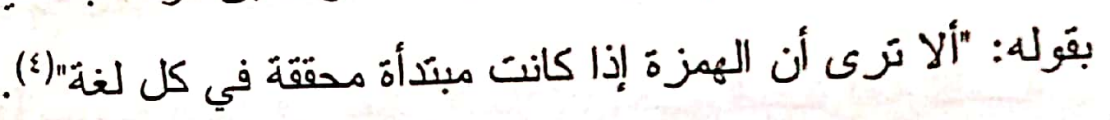

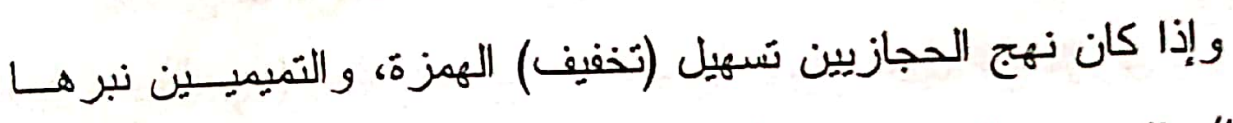

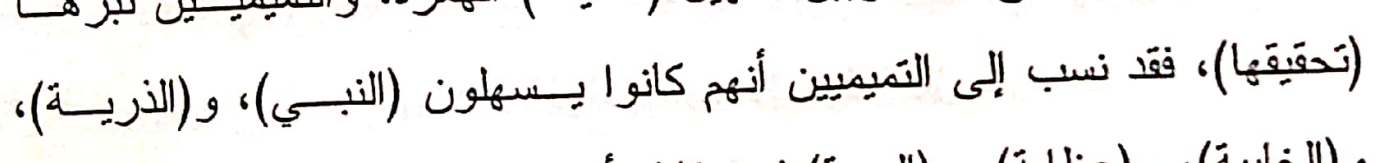

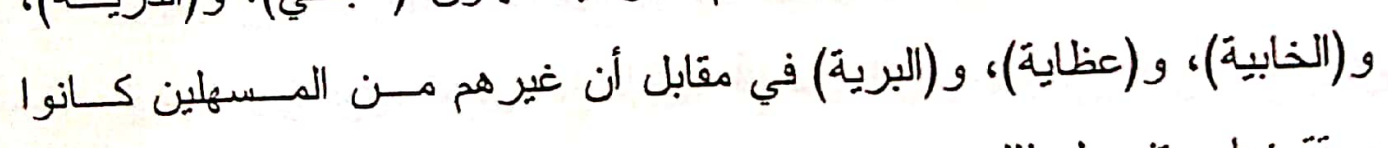
يحقق نها، وتفصيل ذلك:

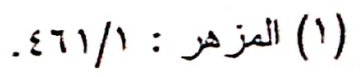

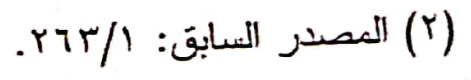

$$
\begin{aligned}
& \text { (r) إعراب القرآن: } \\
& \text { (؛) الكتاب: "ro }
\end{aligned}
$$


أن القبائل العربية قد خالفت مذهبها في النبر و التسهيل في أربعة ألفاظط هي:

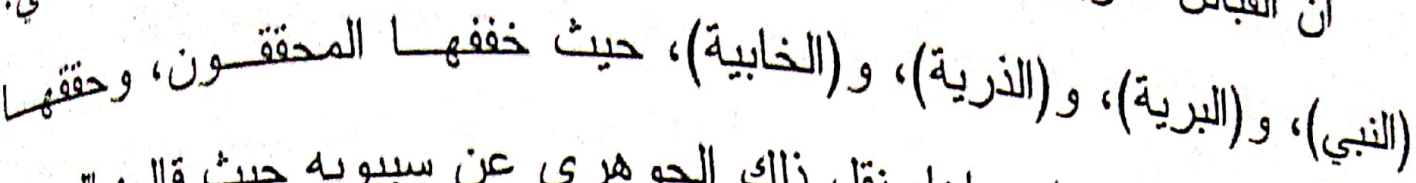

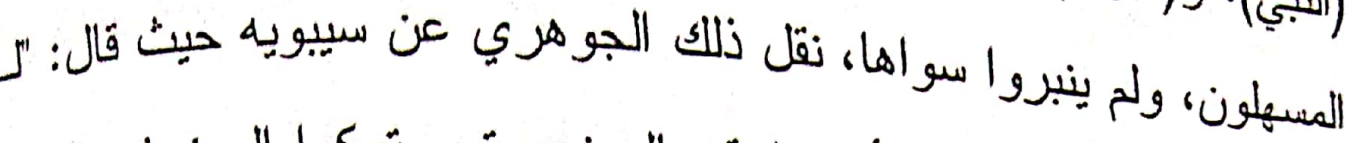
أحد في مكة إلا ويقول: تتبأ مسيلمة، بالهمز ، وتميم تركوا الهمز في النبي، كما

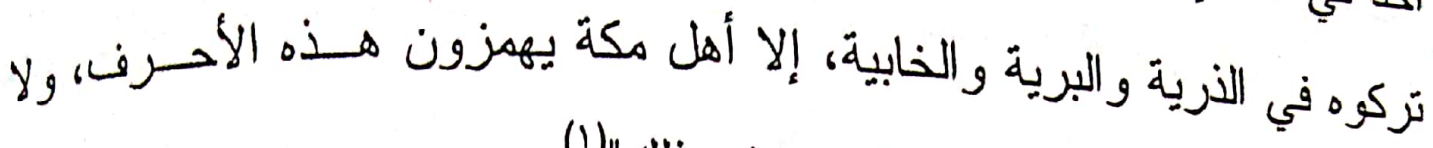

يهمزون في غير ها، ويخالفون العرب في ذلك" (1).

كما نقل ابن السكيت عن يونس أنه قال بمثل هذا الر أي. (r)

و إذا ما عدنا إلى كتاب سيويه لتحقيق ما عزي إليه نجده يقول: " وقالوا

نبي وبرية، فألزمها أهل التحقيق البدل، وليس كل شيء نحوها يفعل به ذا، إنما يؤخذ بالسمع، وقد بلغنا أن قومتا من أهل الحجاز من أهل التحقيق يحققون نبيء

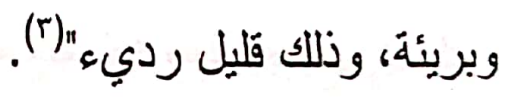

وقد استردأ سيليويه الهمز في بعض الكلمات، نحــو اســتردائه كلمـة

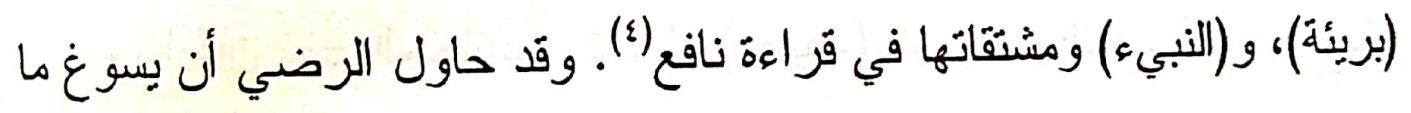
وقع فيه سيبويه من وصف هذه القر اءة بالرداءة بقوله" لعل القراءات السبع عنده لكِّت متواترة، و إلا لم يحكم برداءة ما ثبت أنه من القر آن الكريم" (o).

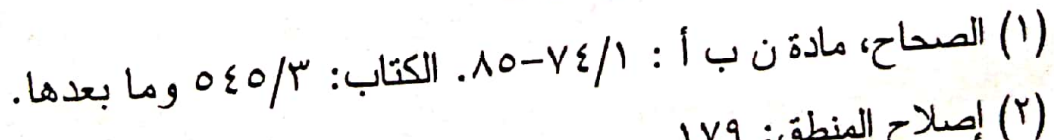

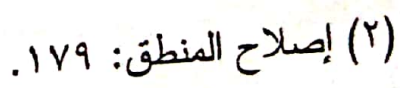

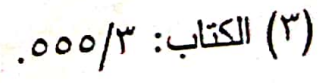

$$
\begin{aligned}
& \text { () (乡) المصدر السابق. }
\end{aligned}
$$

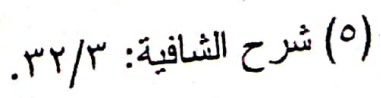


أما أبو علي الفارسي فيرى أن سيبويه إنما استردأ ذلك؛ لأن الغالب في

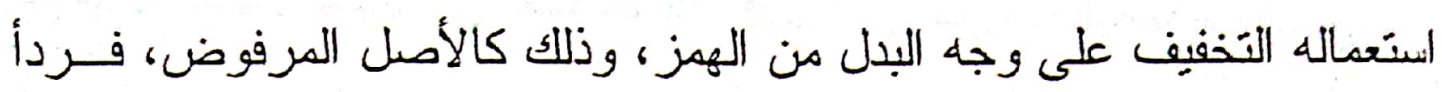
عنده ذللك لاستعمالهم فيه الأصل الأي قد تركه سائرهم، لا لأن النبي الهمز فيه لهيه غير الأصل، و لا لأنه بحتمل وجهين كما احتمل عضدة، وسنَة" (1). وندن لا ننفي هذا الاحتمال الذي افترضه الرضي، و لا سيما أن عصر

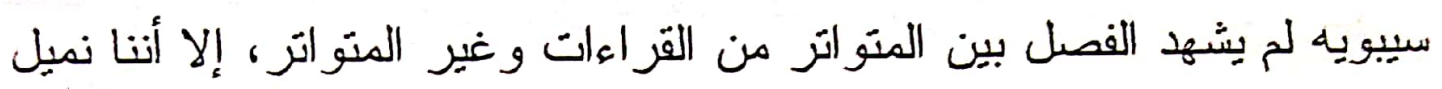

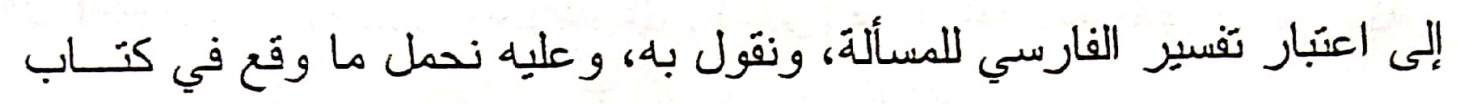
سيايوبه من وصف بعض القر اءات بالقلة أو بالرداءة، وقد مضى أن وصف لغة ولة ما بالرداءة لا يقتضي عدم صحتها، ونكرر مرة أخرى بأن اللغة القليلة لا ترد

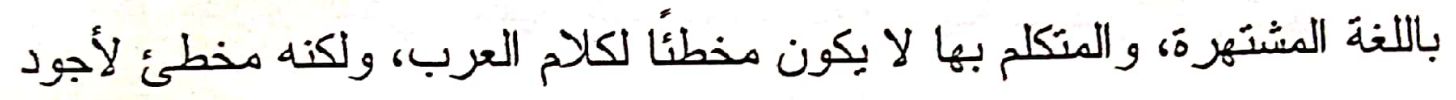
اللغتيّن، و القر آن الكريم نزل بلغات العرب صحيحها وشاذها (r). على أن من الجدير ملاحظتها أن الفارسي لم يكن مطردًا فـي مسسألة

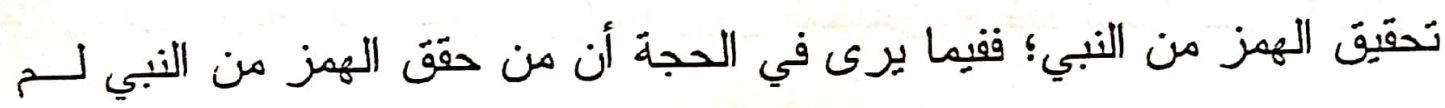

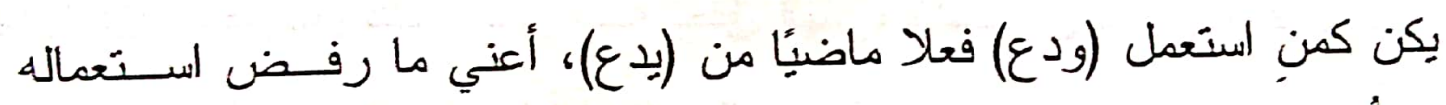

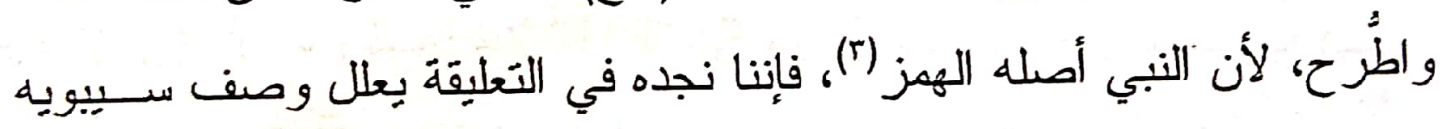

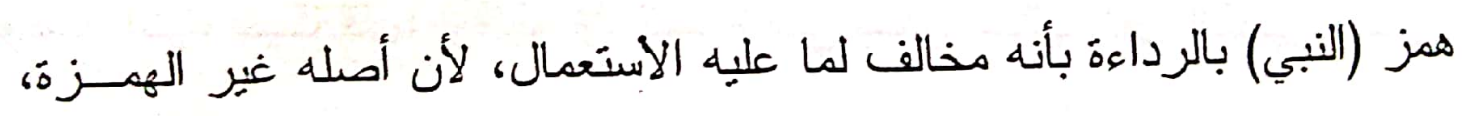

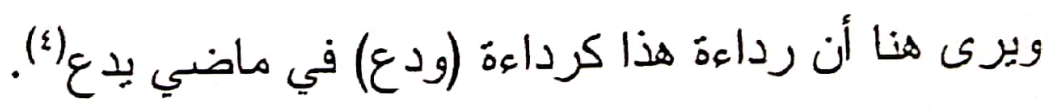

(1) الحجة للفارسي: $91 /$ (1).

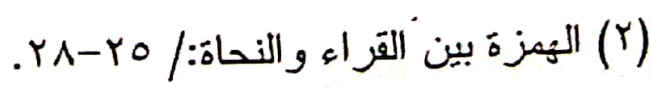

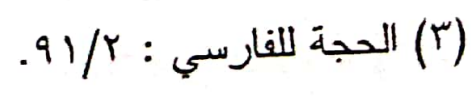

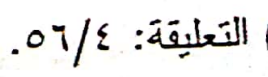


ولعل الذي دعا بعضهم إلى استبعاد قَ اعة نافع بهمز (النبيء) أن نافكا.

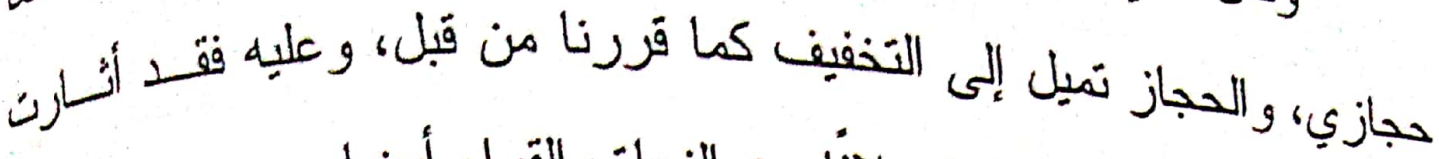
قراعته بالهمز في هذه الكلمة خلافا بين النحاة و القز اء أيضا.

وقد حاول أحد المحدثين تفسير ما وقَع من تُحقيق الهمز في قَرَاهُ نساقع وغيره ممن هم من أهل التخفيف، ولكن الاضطر اب في هــــه المحاولسة كسان واضخًا؛ فهو تارة يقول بأن الهمز قَ ملك على الناس شعور ههم، وبذلك فسسر همز (النبيين)، و (النبيون)، و(النبوة)، و (النبي) في قز اعة نافع الذي هو من بيئة

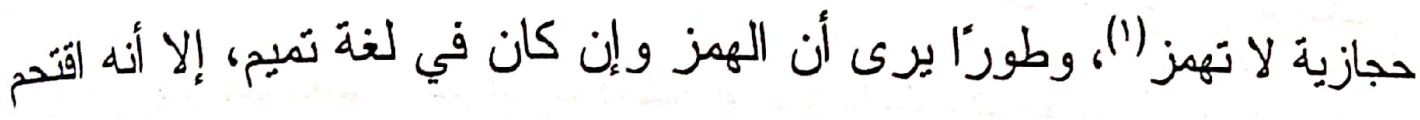

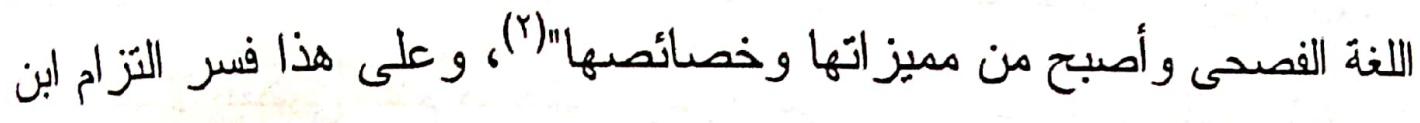
كثير، وهو القارئ المكي، تحقيق الهززة، مع أنه في بيئة الحجاز التي تسهله. ومن ثم يمكن القول إن سيبويه لم يـــص إلا علــى كلمتــي (نبــيء)

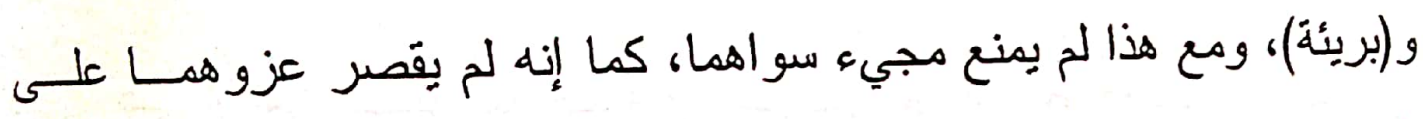

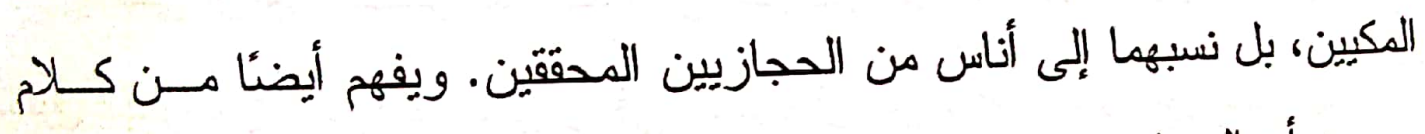

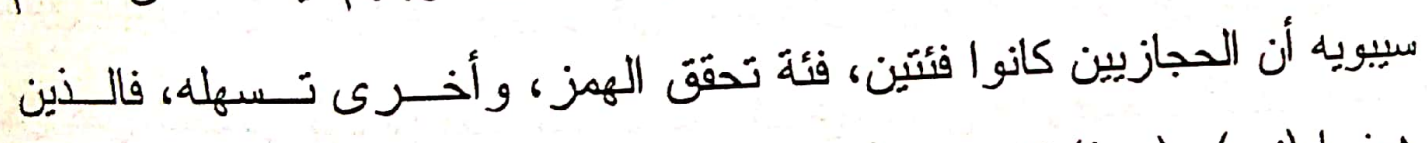

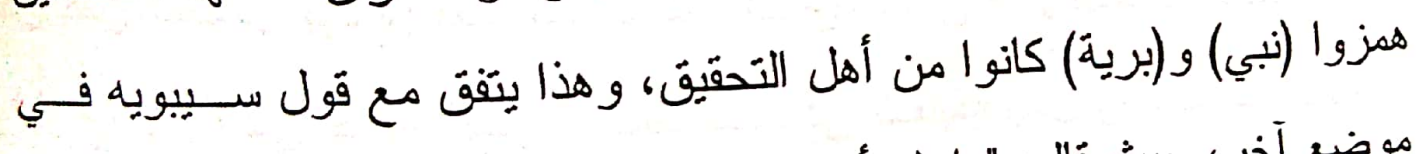

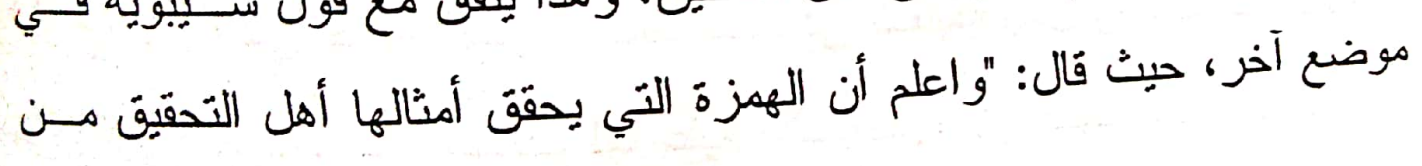

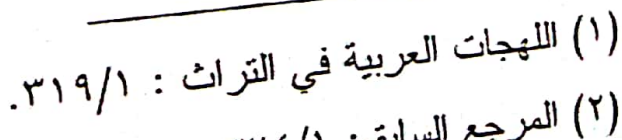

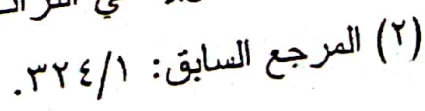




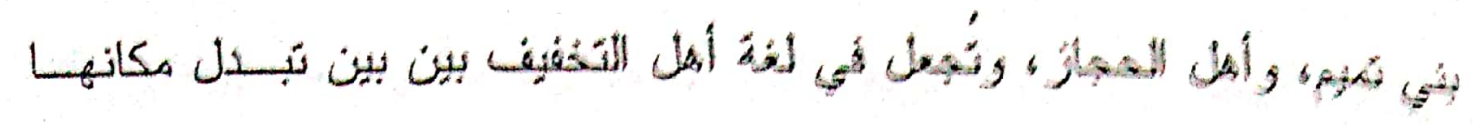
(1)

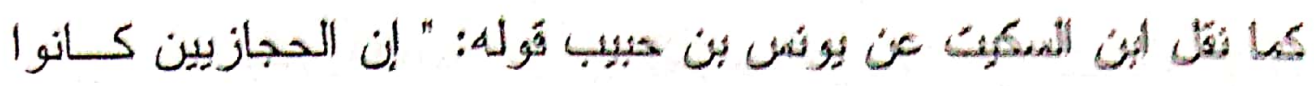

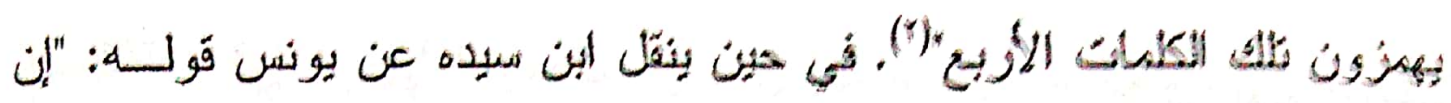

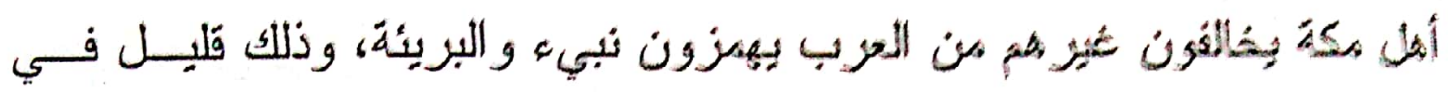

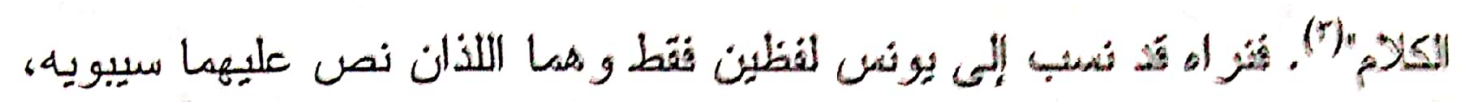

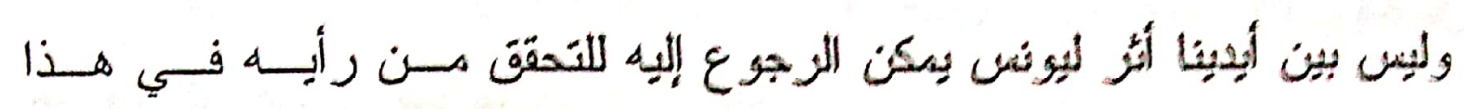
الإموضون

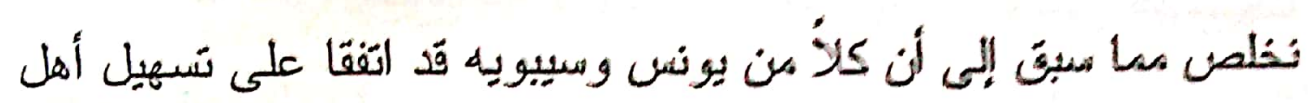

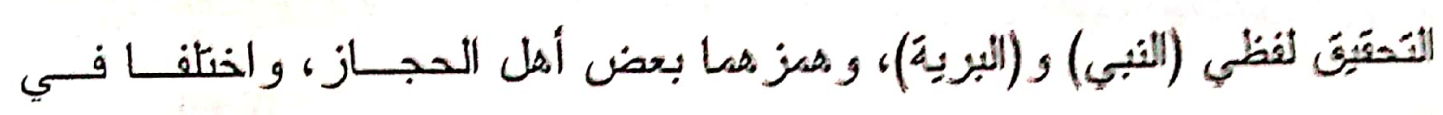

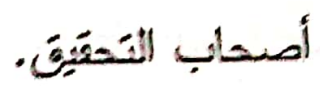

وإذا ما نظزنا نظزة تاريخية في الصيخ التميمية نجدها المنطورة، ودليل

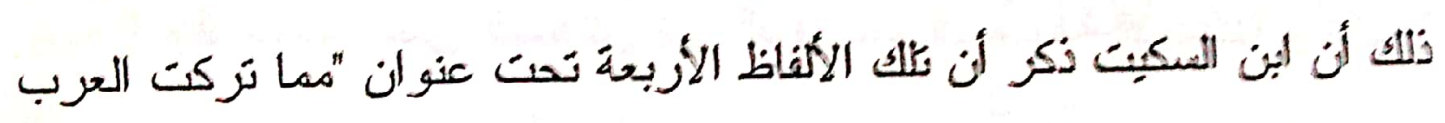

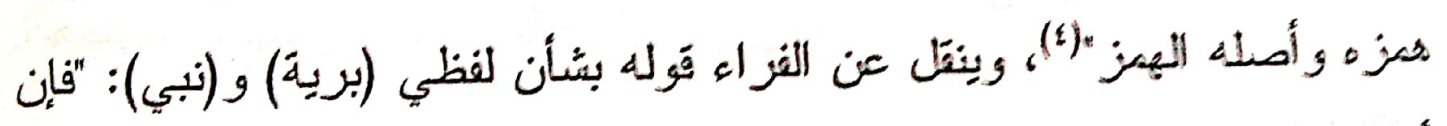

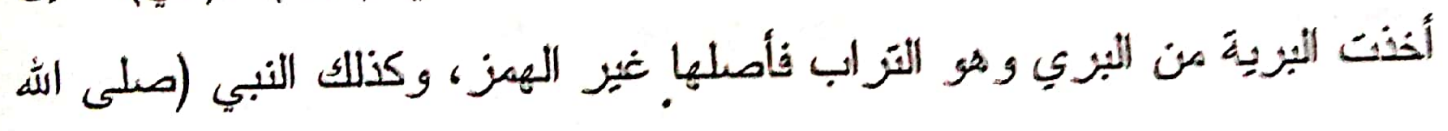

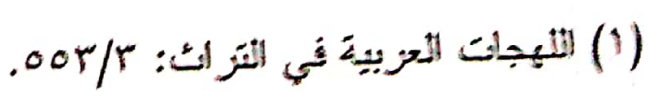

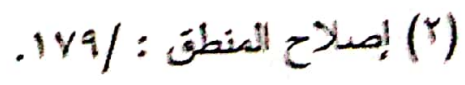

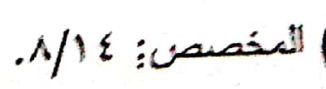

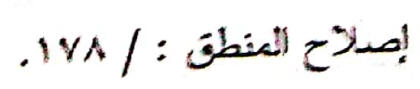


عليه وسلم)، هو من أنبأ عن اله عز وجل، فترك همز م، و إن أخذته هن النبوة،

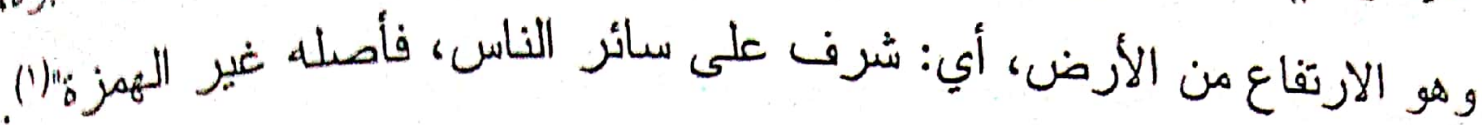

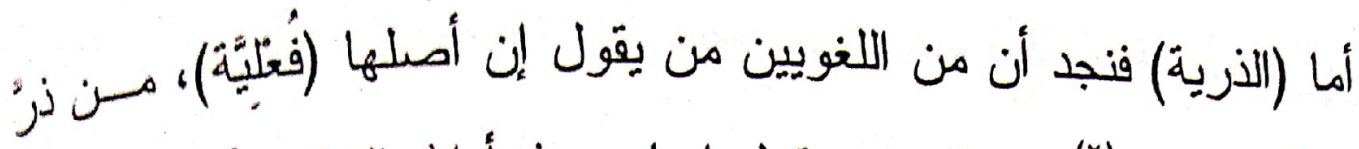
اله الخلق، أي: فرقهم (Y)، و هناك من يقول إنها من ذرأ اله الخلق، أي: خلقهـي، وهي لغة في ذرى(r). و إذا ما انتقلنا إلى اللفظ الرابع و هو (الخابية) فسنجد أنهم يقولون إنه من

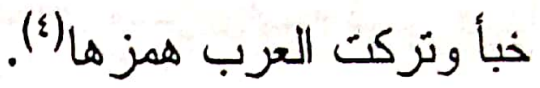

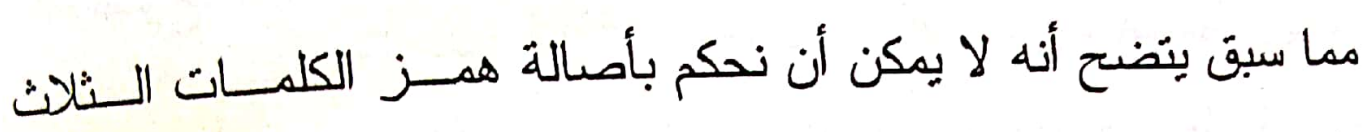

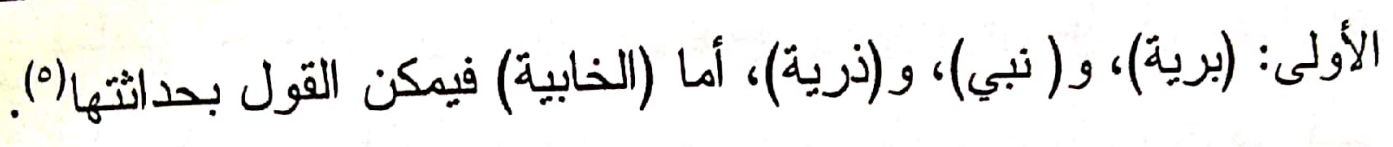
أما (ذوي) فقد نسب الأصمعي استعمالها دون همز إلى النجديين، فـي

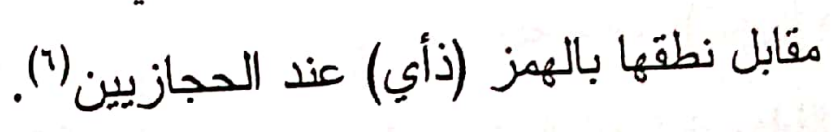
وقَّ ذهب بعض المحدثين إلى القول بقدم الــصيغة النجديــة ونطــــور الحجازية عنها، واستتد في ذلك إلى أمرين:

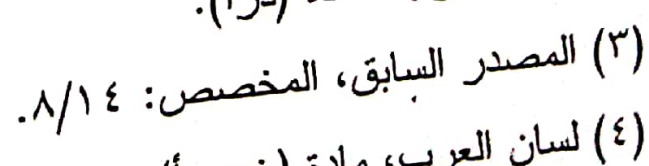

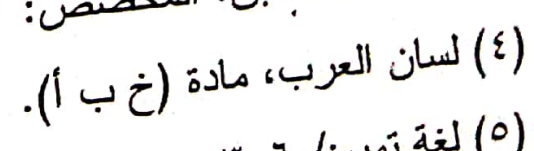

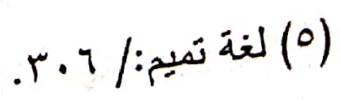

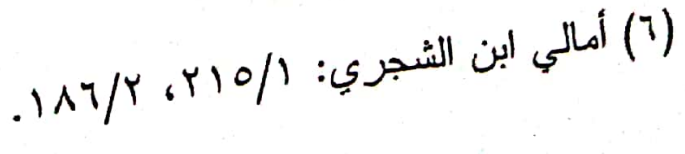




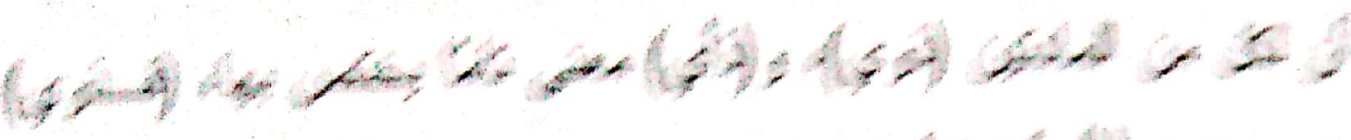

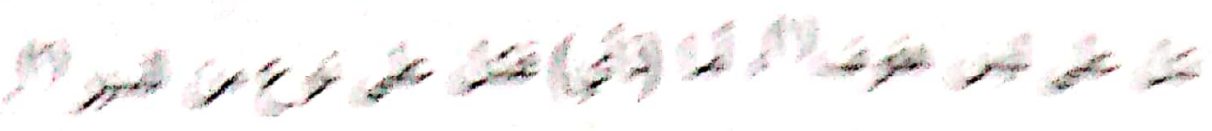

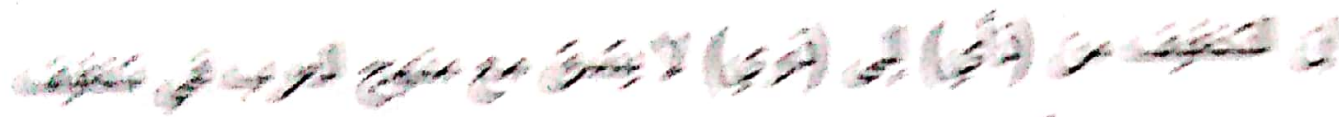

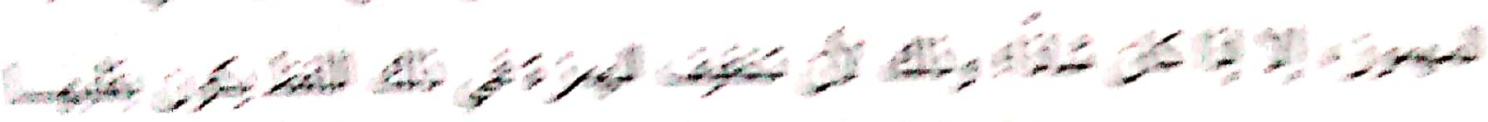

$$
\text { (n) }
$$

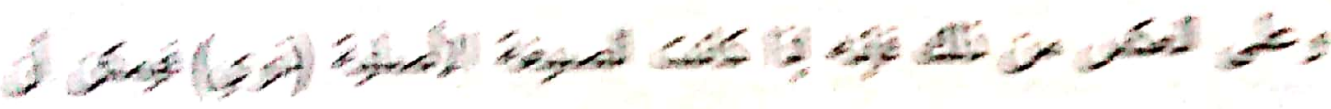

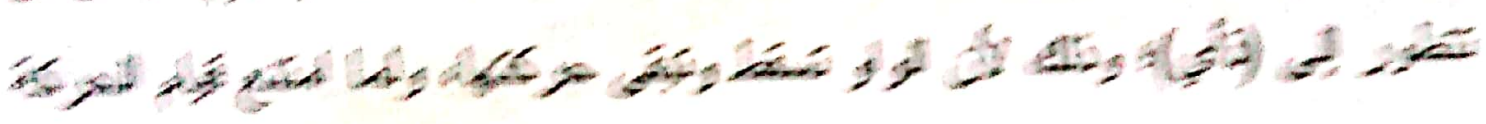

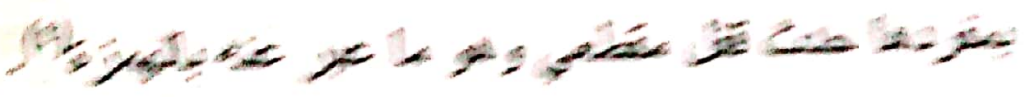

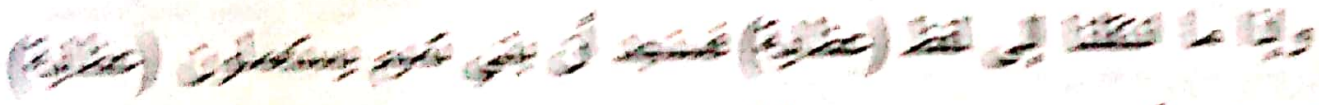
, ب p)

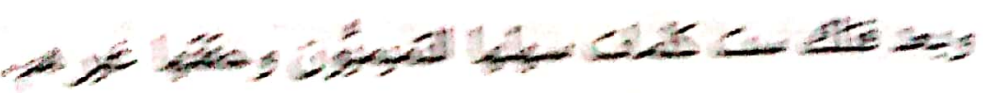

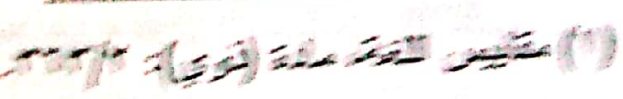

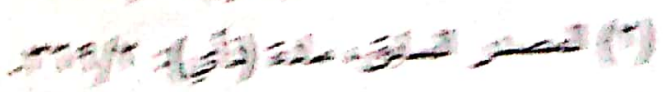

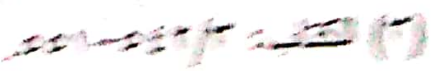

$$
\begin{aligned}
& \text {-xwas }
\end{aligned}
$$

God

$$
x-x=2 x=0
$$


ومما يرتبط بهذه المسألة وأود أن أعرض له في هذا المقــام، النطـــور الذي حدث في الصيغة اللغوية لبعض تصاريف الفعل (رأى) -إذا كانت الرؤية

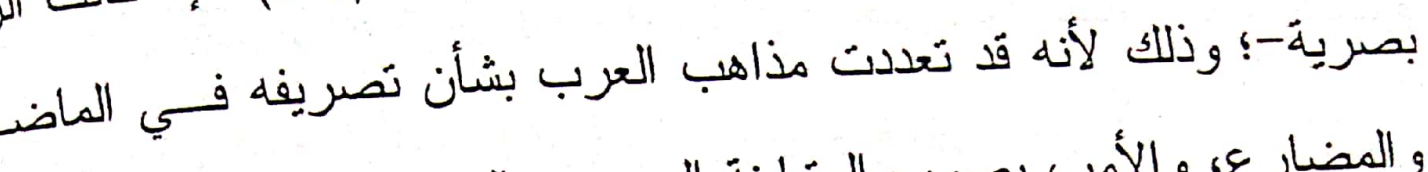

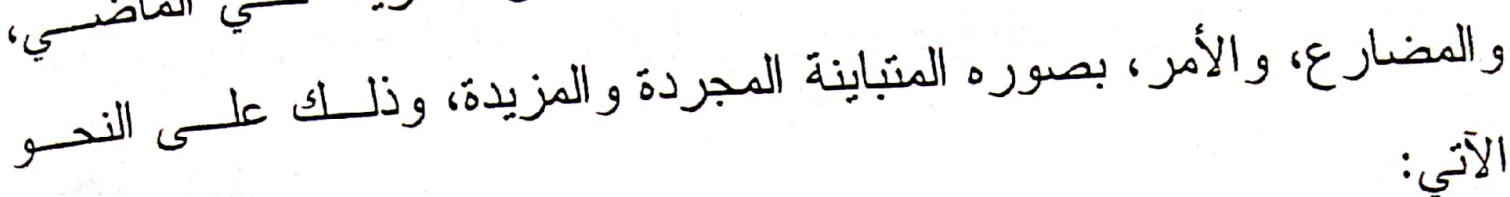
الآتي:

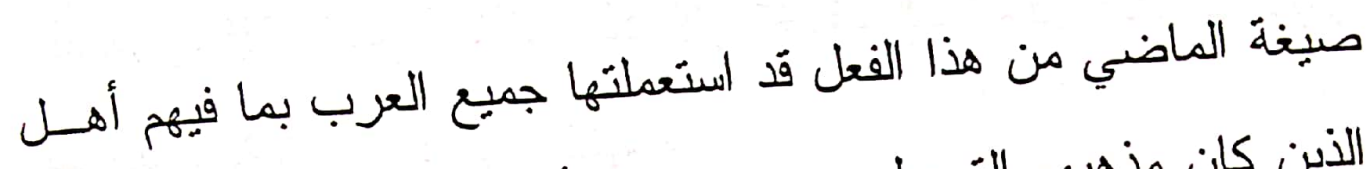

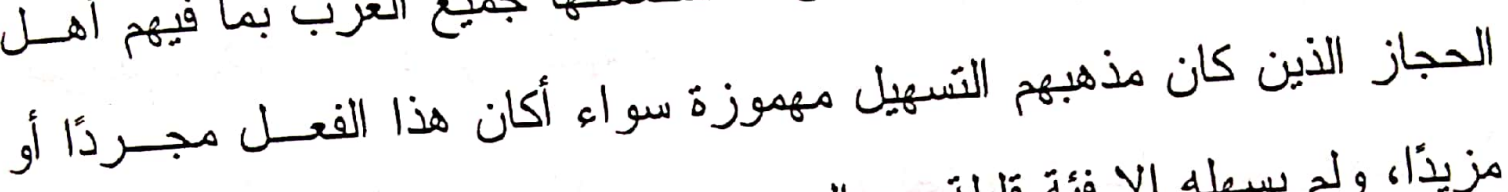

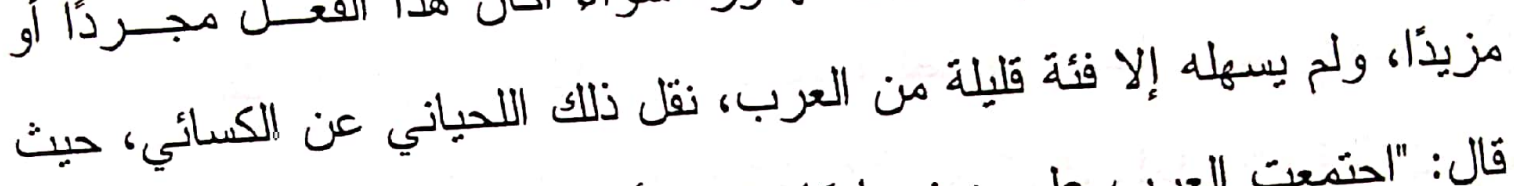

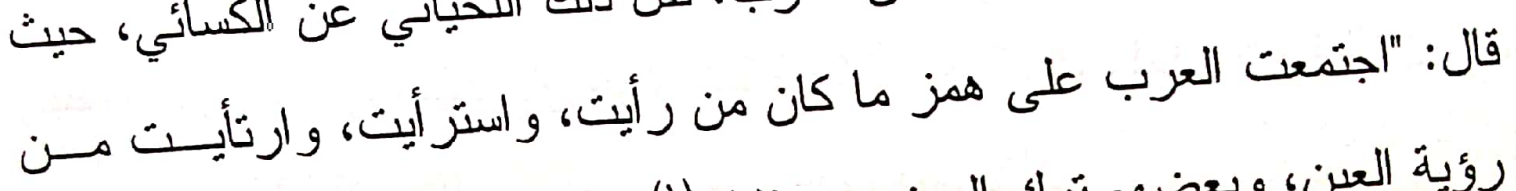

رؤية العين، وبعضهم نرك الهمز وهو قليل"(1).

ولم أقف على أحد من اللغويين عين هؤلاء البعض الذين نركوا الهمز .

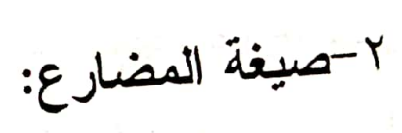

أما صبغة المضار ع، فقد اتفق جميع العرب على ترك همز ها، فقالوا: "

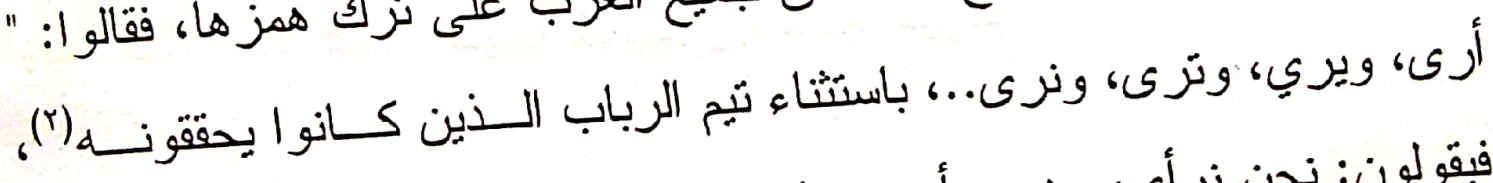

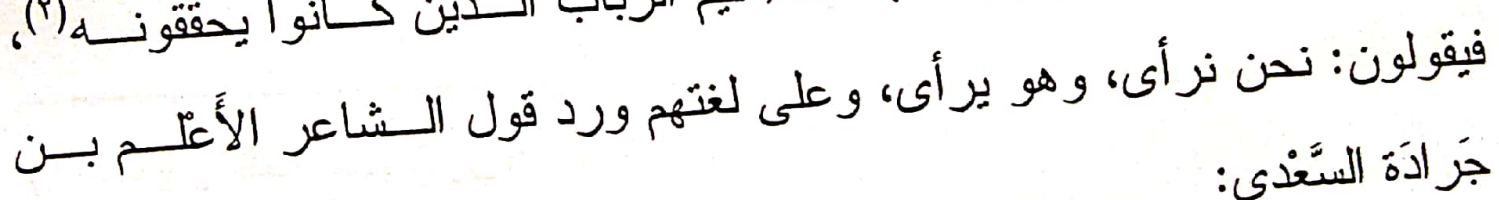

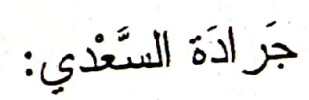

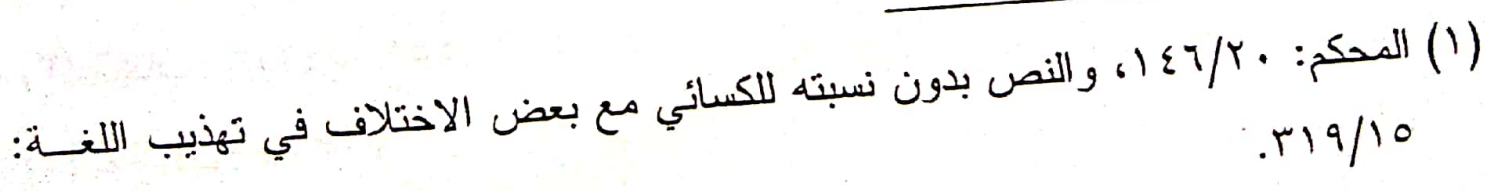

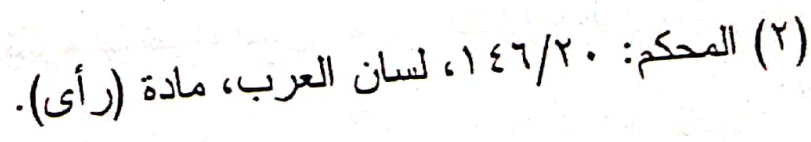




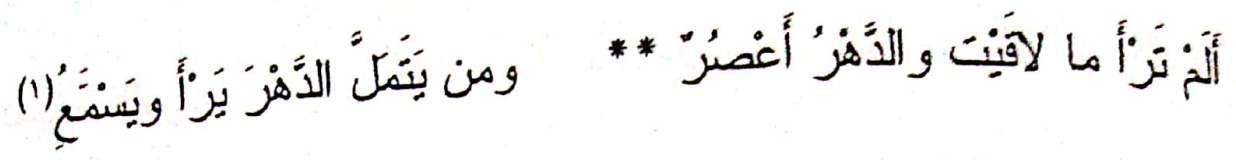
وقَّل الآخر:

أرى عيني ما لم تر أياه *** كلانا عالم بالترهات(r)

و انفزد أبو حيان بأنه عزا إلى التميميين تحقيق هذه الصيخ فنتل عنهم أنهم كانوا

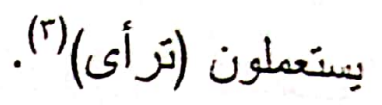

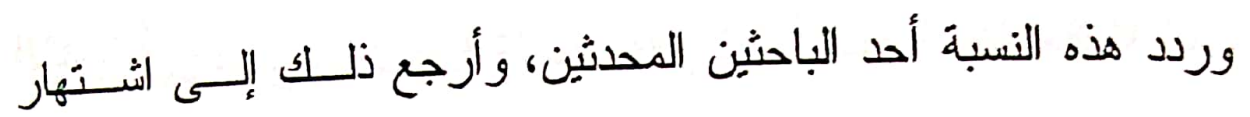

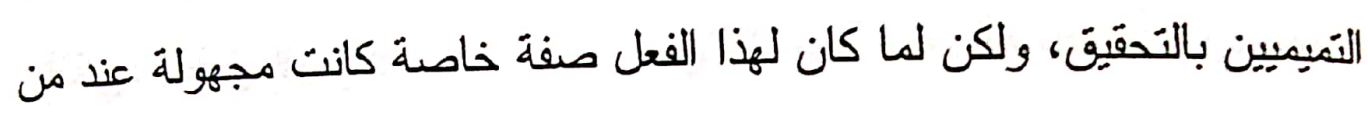
نسبه وحسب أنه مثل غيره من الألفاظ المهوزة فنسب تحقيقها إلى التميميسين. كما قال باحتمال حدوث تصحيف في تيم لنكون تعيم (\&). ولهييويه نص صريح يعضد رأيه في عزو تسهيل مضار ع هذا الفتسل

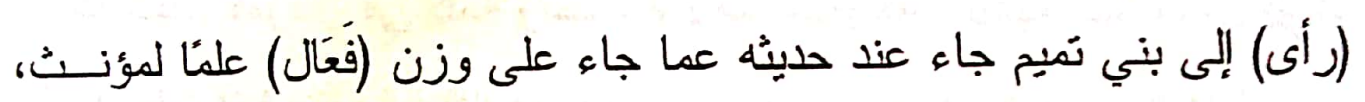

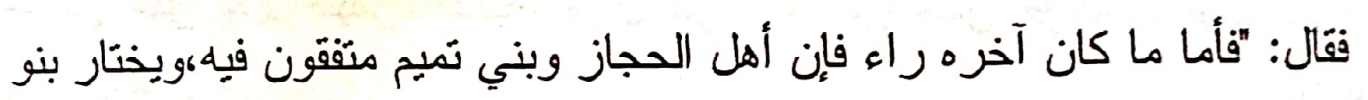

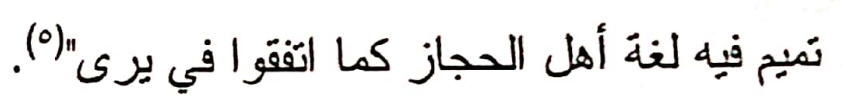

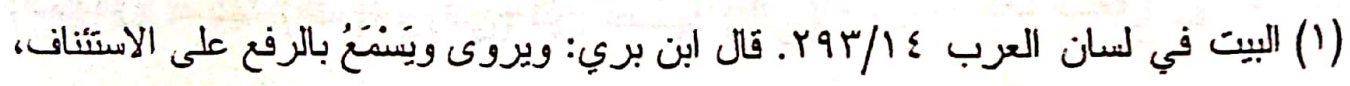
لأَنْ القصيدة مرفو عة وبعده:

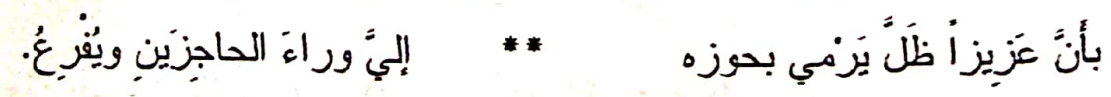

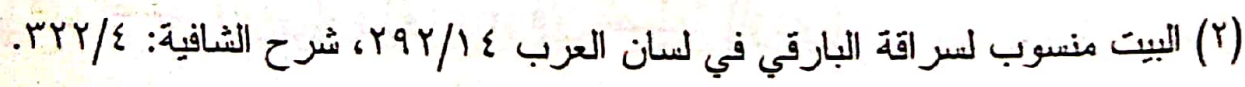

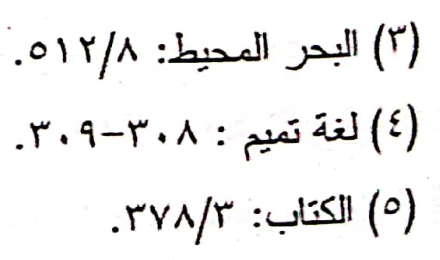




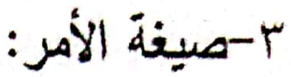

أما صيغة الأمر، فقد كان للقبائل العربية في استخدامها مذهبان:

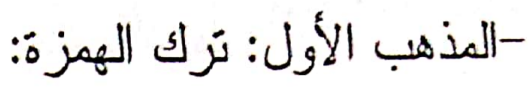

و هذا نهج أهل الحجاز ، فكانوا يقولون: (رِ) للمفـرد، و (ِرِيّ) للمفـــدة

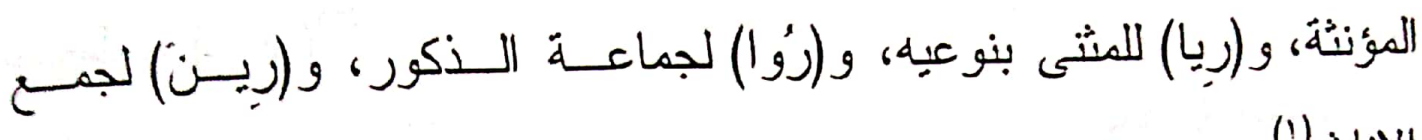

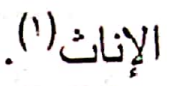

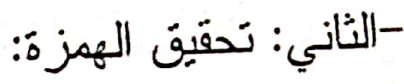

وهو مذهب التميميين، فكانو ا يقولون مثلا: (ارأ)، و (ارأيا)(r).

القسم الثاني: الهمزتان المجتمعتان في كلمة واحدة:

إذا التقَت همزتان في كلمة واحدة، أو لاهما منحركة و الثانية ساكنة، فـالقر اء

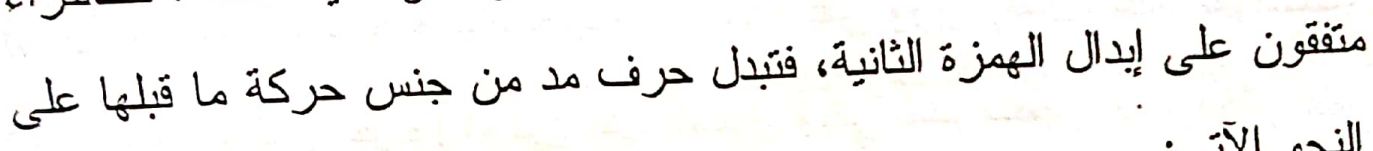
النحو الآتي:

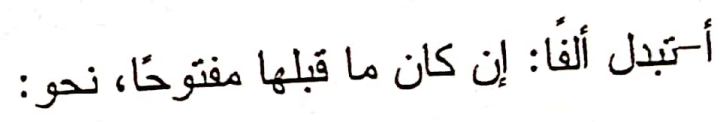

(آدم) فإن أصلها (ألَّم)، و (آتى) فإن أصلها (ألنّى).

ب- بتبّل واوًا، إذا كان ما قَبلها مضمومئا، نحو:

(أُوتي) فإن أصلها (أُؤنَ)، و (أوذي)، فإن أصلها (أؤذي).

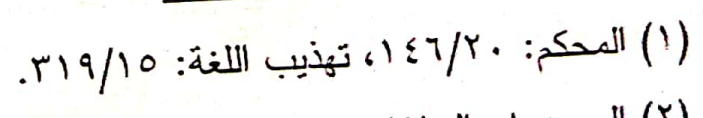

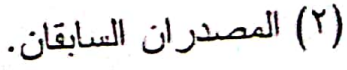




\section{جمتبل ياء، إذا كان ما قبلها مكسورزا، نحو:}

(إيعانا) فإن أصلها (إِمْاناً)، و لا نعلم خلافا بين القراء و النحاة في هذه القاعدة.

أما إذا تحركت الهمزتان المجتمعتان في كلمة واحدة مئــا فلههــا خمسسة

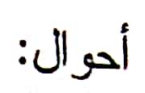

\section{ا- إبدال الثانية وجوبًا ياءُ أو واوًا:}

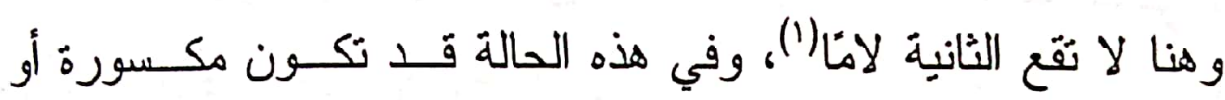

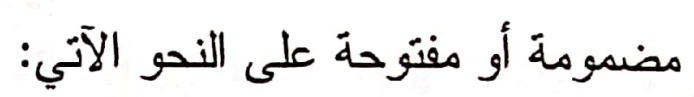

أ- فإذا كانت مكسورةً أبدلت باء بقطع النظر عن حركة الأولى، ندو: (أبِّمة).

ب-و إذا كانت مضمومة نطقت واؤا، فمضارع (يؤم) للمـنـلم (أَوُم)، و (أوم)،

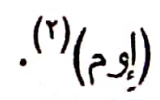

ج- و إذا جاءيت مفتوحة فإنها تبل باءً إذا كانت بعد هزة مكسورة، نحو : (إِِم) من أَمَ.

$$
\text { د-و إنن جاءت بعد همزة مضمومة تبدل واوَّا، نحو : (أُوْم). }
$$

هـ- أما إن وقعت بعد همزة مفتوحة فقد اختلف فيها، فبعضهم يبلها واوّا عند

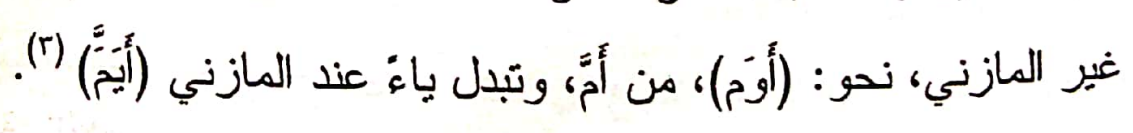

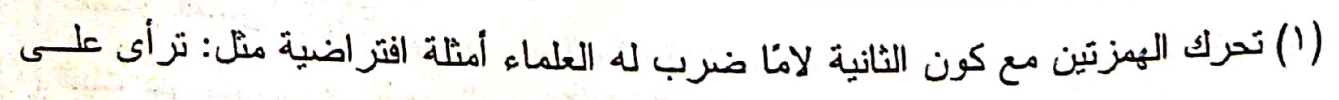

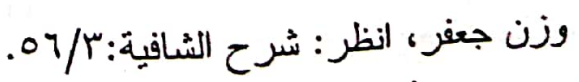

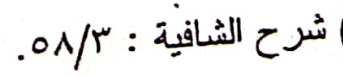

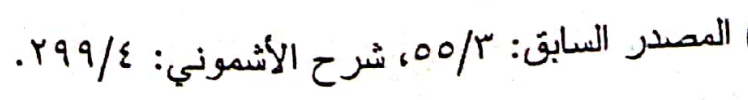




\section{r- تحفيني النيززتان المتحركتن ("):}

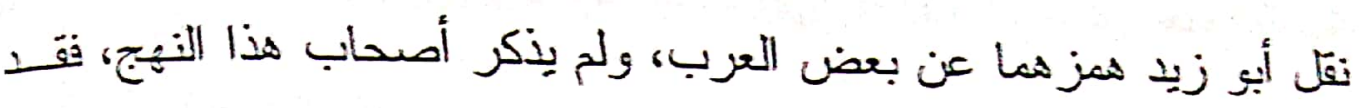

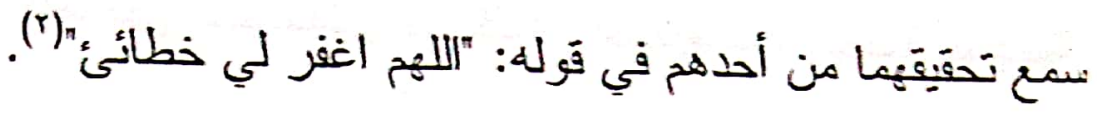

$$
\begin{aligned}
& \text { كما وردئا محقَتين في قَّل النشاعر: }
\end{aligned}
$$

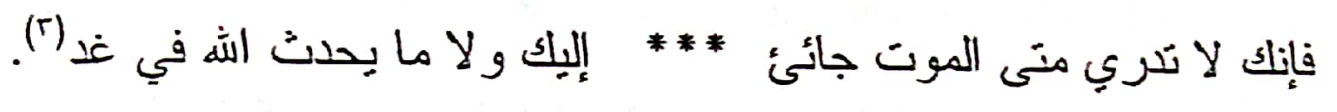

r- تحقيق الأولى ونسهيل الهمزة الثانية:

فمنهم من بيسهل الهمزة الثانية، نحو : (أيمة)، وهذا التسهيل شبيه بتخفيف

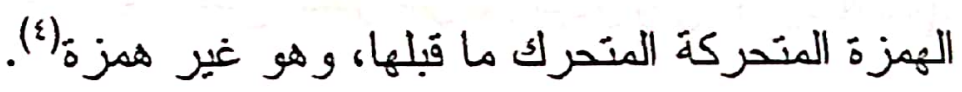

؛- تحقيقهما وزيادة ألف بينهما:

فيقال : أائمة (آئمة) (०)

0- تحقيق الأولى وتسهيل الثانية وزيادة ألف بينهما:

وذلك نحو : (أيمة) (آيمة) (").

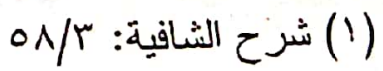

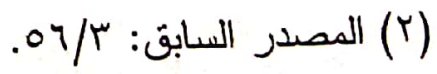

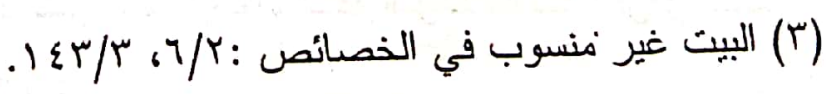

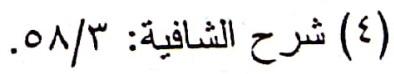

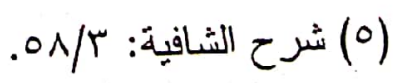

$$
\begin{aligned}
& \text { (7) المصدر السابق. }
\end{aligned}
$$


وقد قر أ القز اء كلمة (أئمة) وفق المذاهب المختلفة التي نسبت للمحفقين ('). القسم الثالث: الهمزتان المجتمعتان في كلمتين متجاورتين: أما إذا اجتمعت همزتان في لفظين فلا تكون الثانية إلا منحركة، لأنها فـي ألمي أول اللفظ، أما الأولى فهي إما استفهامية أو غيرها. أو لا: إذا كانت الأولى استفهاميةًة):

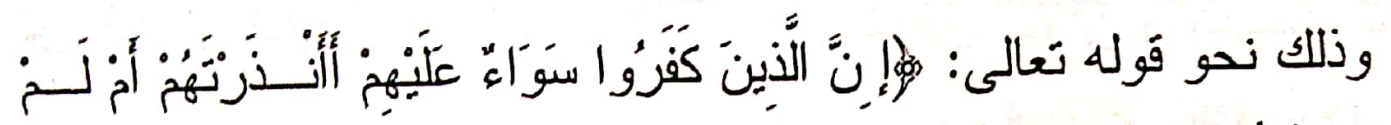

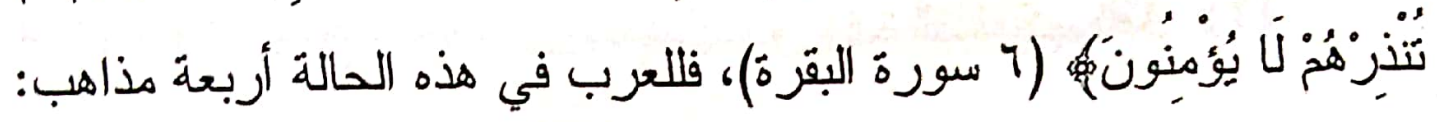

- الأول: تحقيق الأولى وتسهيل الثانية)("). - الثاني: تحقَقِهماً(). ولم أقف على أصحاب هذا الدذهب. - الثالث: تحقيق الأولى وتسهيل الثانية وزيادة ألف بينهما(') ونسب إلى أهـل الحجاز (i).

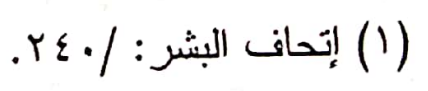

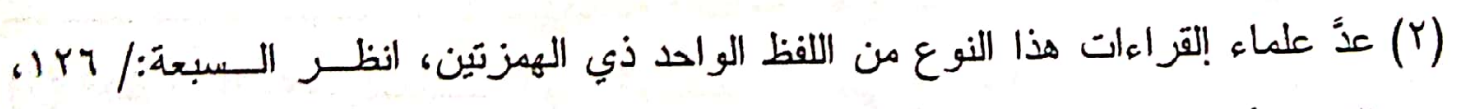

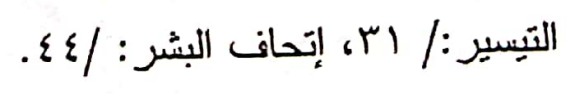

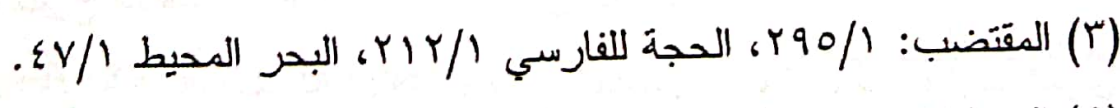

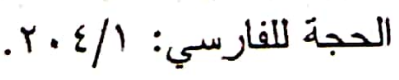

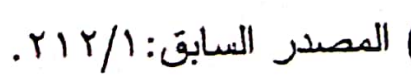

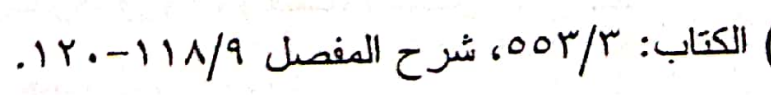




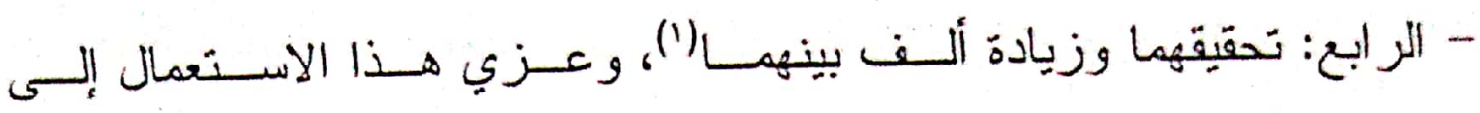

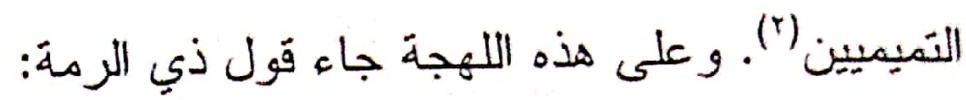

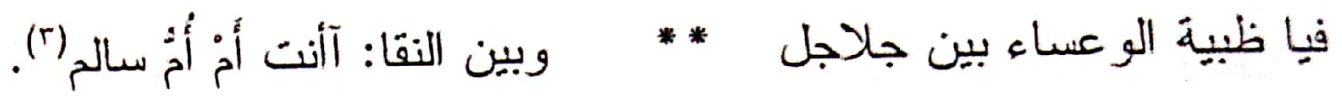
و إذا وقفنا على موقف القراء من الآية القرآنية التي سبق التشثيل بهــا مـنـ

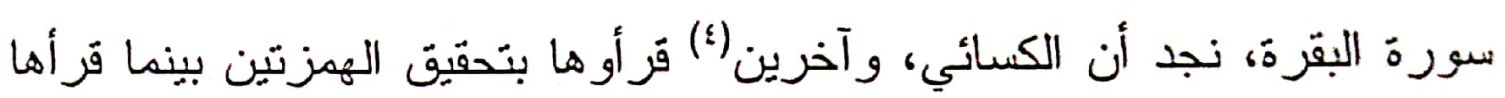

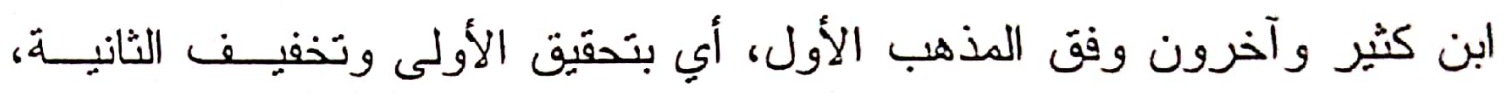
وقر أها هشام وفقا لمذهب التميميين بتحقيقهما وزيادة ألف بينهما (ه). ثانيا: إذا كانت الأولى غير استفهامية: فهي إما متحركة أو ساكنة، أما الثانية فلا تأتي إلا متحركة لأنها بداية كلمة كما قلنا سابقا، وتفصيل هذه المسألة على النحو الآتي: أ- فإذا كانت الهمزتان متحركتين: فإن ذلك بِأتي على وجهين: - الوجه الأول: أن تكون الهمزتان متفقتين في الحركة:

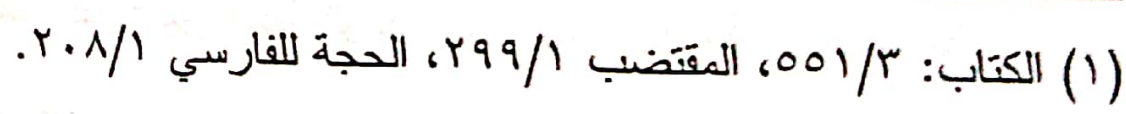

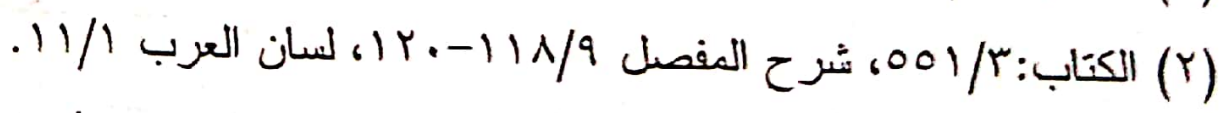

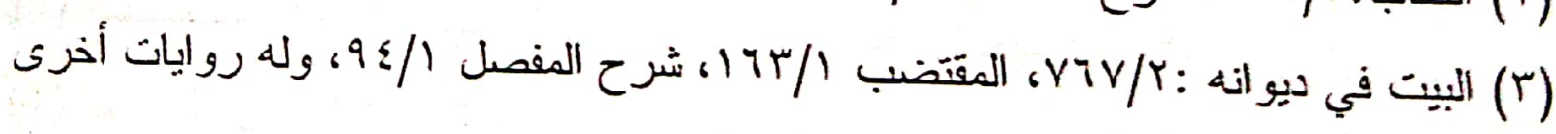

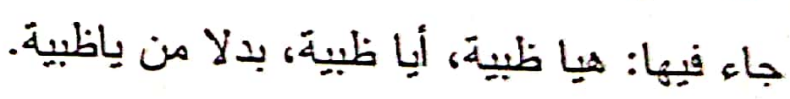

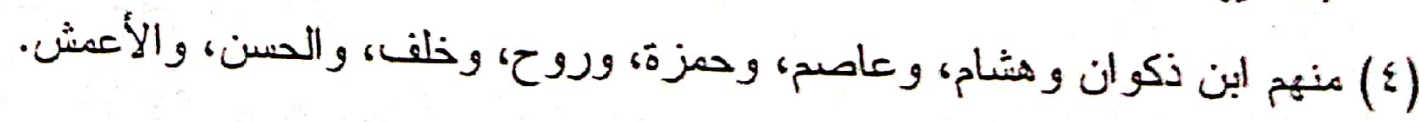

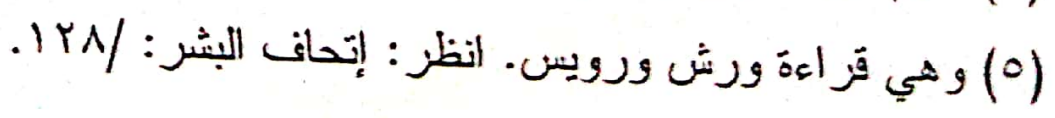




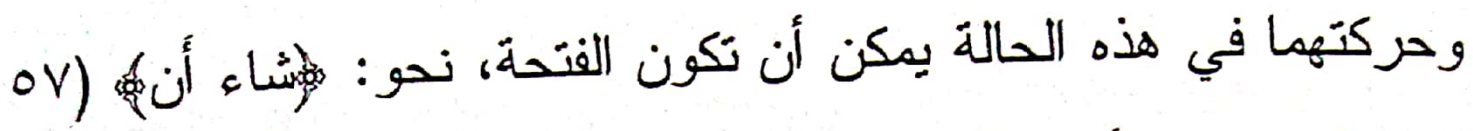

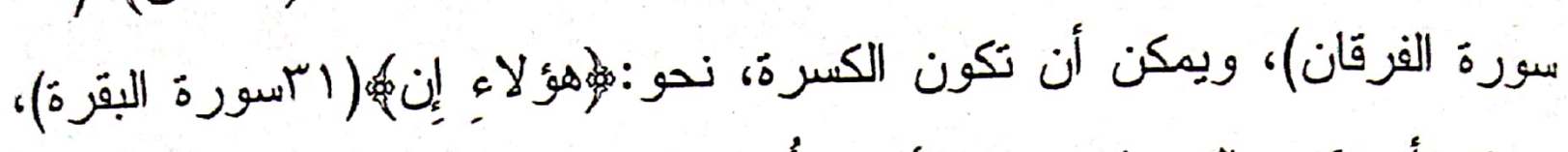

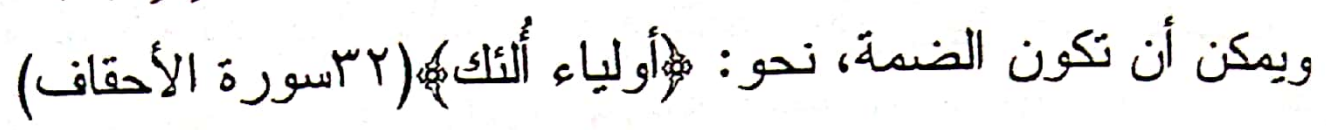
- الوجه الثاني: أن تكون الهمزتان مختلفتين في الحركة: وقد وقع منها في القرآن خمسة نماذج على النحو الآتي:

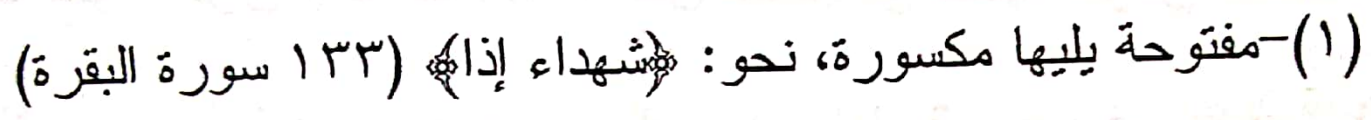

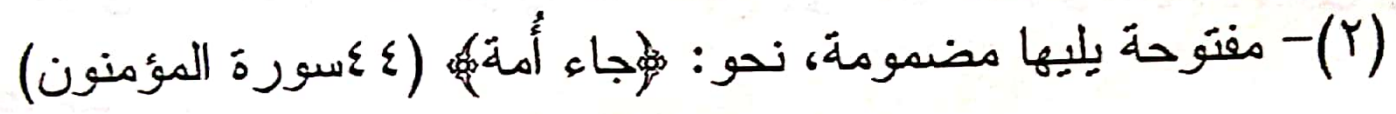

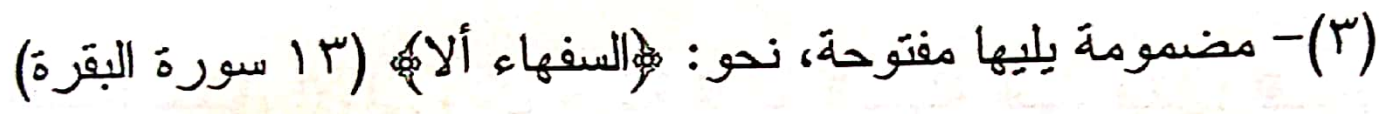

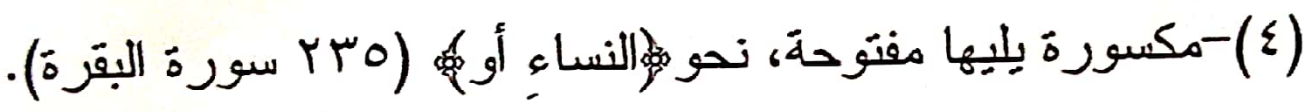

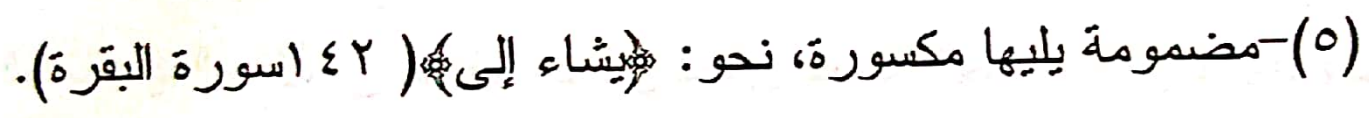
وقَل تتوع أداء القراء في هذه الأوضاع أيضنا، فقرأ نافع وابن كثير وأبو

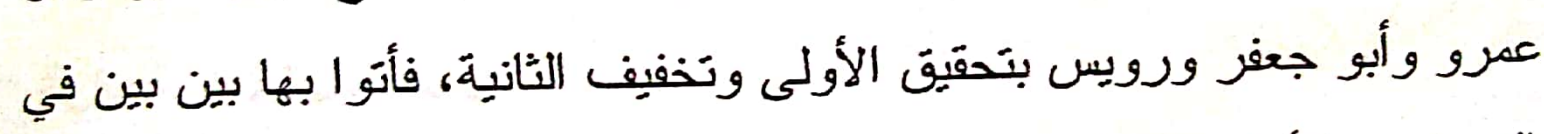

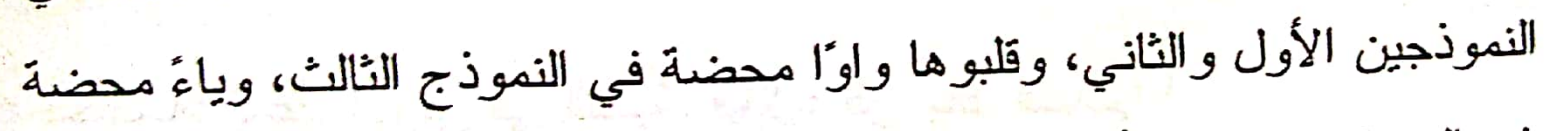

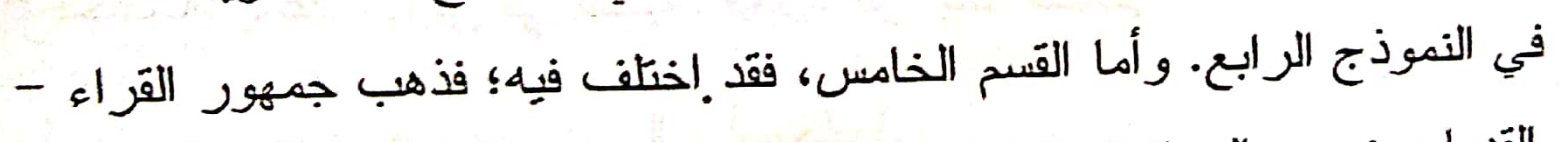

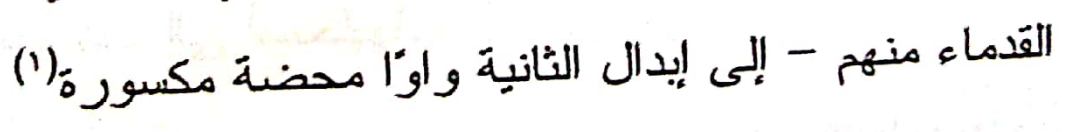

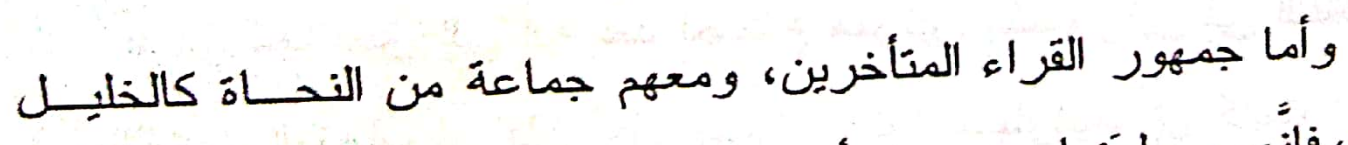

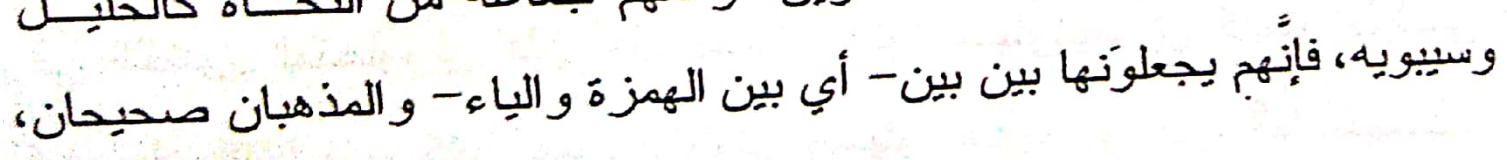

(1) الهمزة بين القراء والنحاة:/ rr-10 
إلا أن الأول آثر في النقل، والثاني أوجه في القياس، وقر أ باقي القراء، وهم ابن

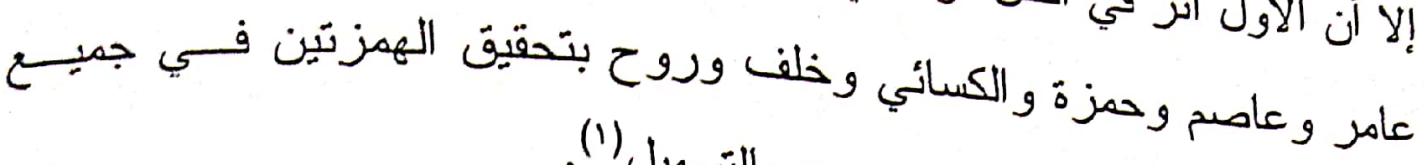
النماذج، وانفرد ابن مهران عن روح باهن والتسهيل (1). ب- أما إذا كاتت الأولى ساكنة والثانية متحركة: وذلك ندو: (اقرئ أباك السلام) فقد كان للقبائل في نطقها طر ائق مختلفة: - الأولى: التسهيل: وقد عزي هذا النهج إلى أهل الحجاز، فهم يقولون (اقــري أباك السلام). - الثانية: تحقيق الأولى ونقل حركة الثانية الدسهلة إليها، فيقال: اقـرئَ بــاك السلام. - الثالثة: إبدال الأولى حرف دد من جنس حركة الحرف الذي قَبلها، وتحقِــن

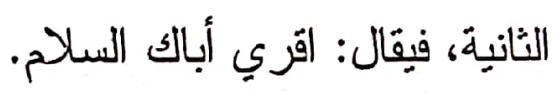
- الر ابعة: تحقَقهما جميعًا.

- الخامسة: إدغام الأولى في الثانية، فيقال: اقر أبَاك السلام (r). ولم أجد من بعزي هذه الدذاهب إلى أصحابها.

ننتهي مما سبق إلى أنه عند اجتماع همزتين متجاورتين في اللفظ الواحد

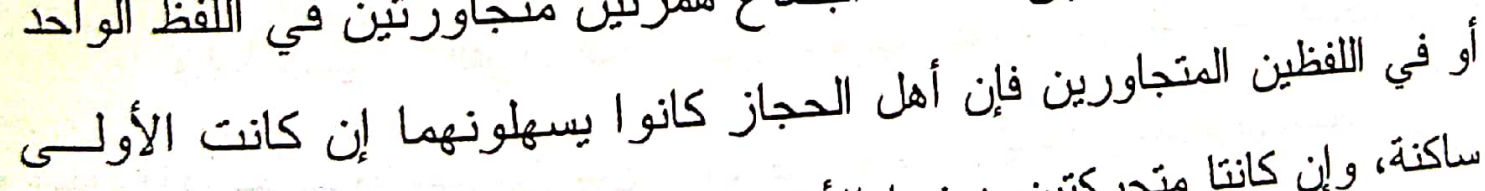

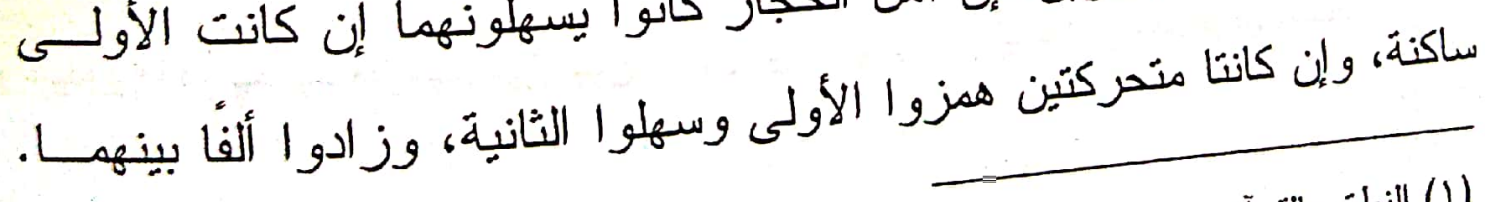

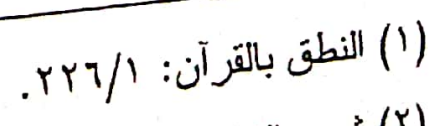

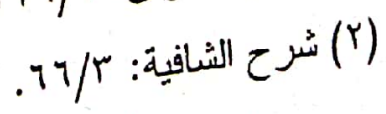




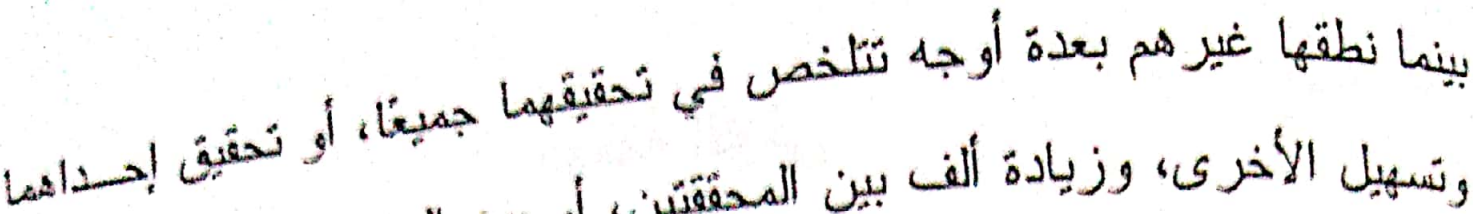

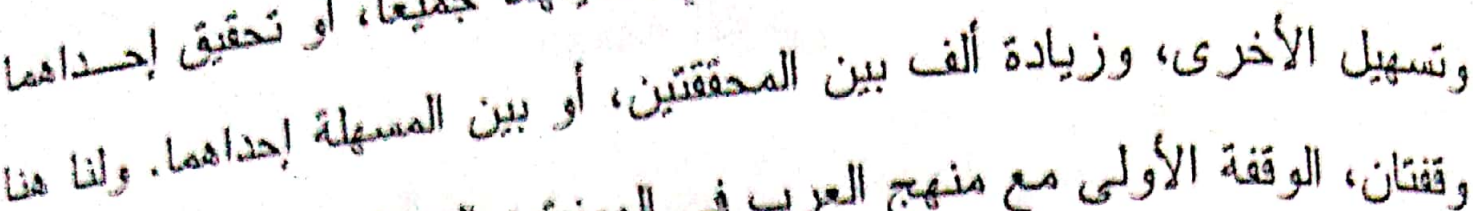

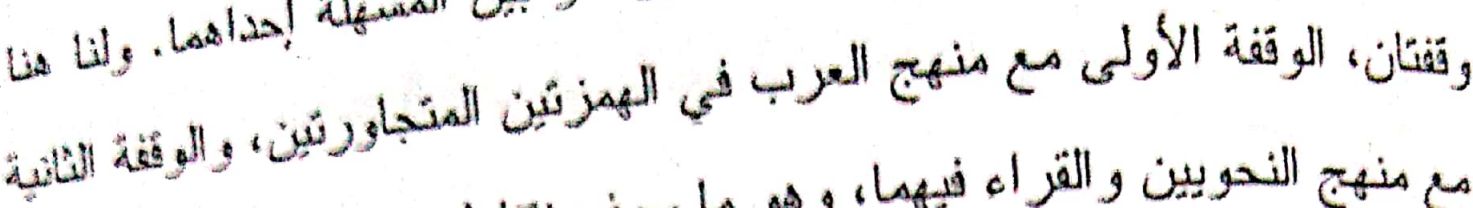

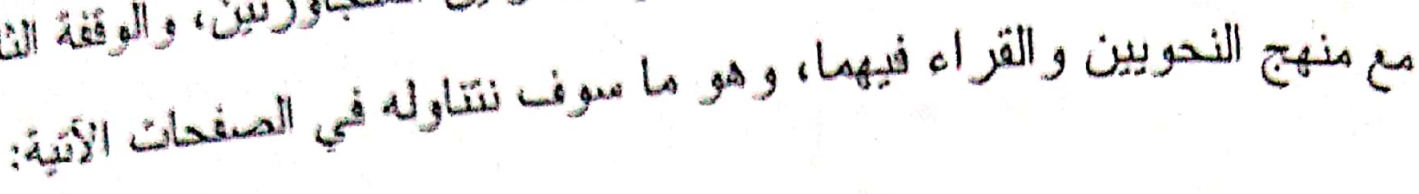




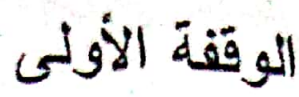

\section{منهج العرب في الهنزتين المتجاورتين}

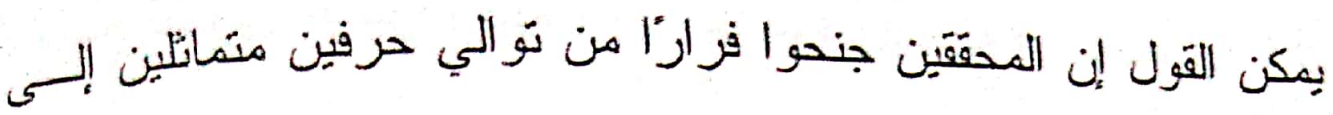
طر ائق خم، هي: الحذن، والإبدال، والتخفيف، و التحقيق، و الزيسـادة (زيسـادة ألف بين الهمزتين)، وفيما يلي بيان ذلك:

1-الحذف:

ويقصد به حذف إحدى الهمزتين، وقَ بحل مكانها صوت آخر ، أو دون

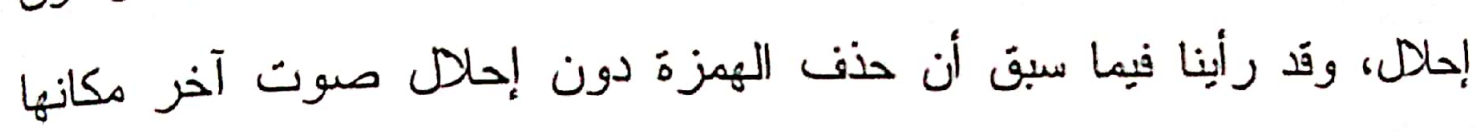
يكون عند المحققين في اللفظين المتجاورين، إذا كانت الهمزتان متفقتسين في

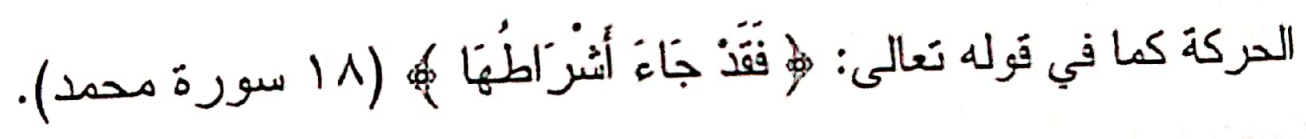

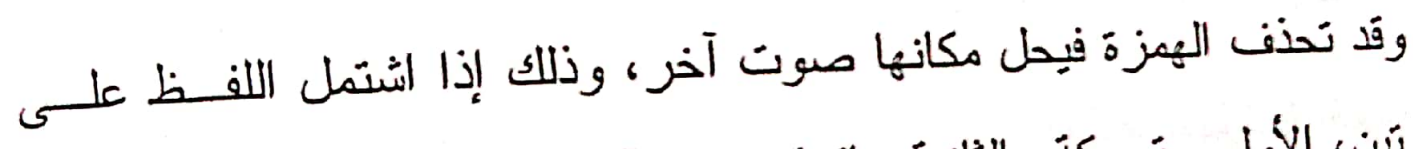

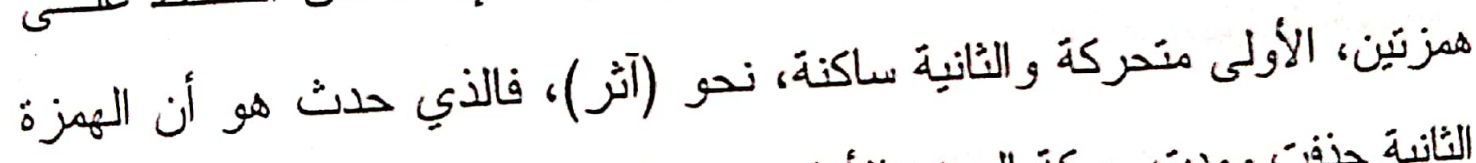
الثانية حذفت ومدت حركة الهمزة الأولى.

كما أندا إذا اجتمعت همزتان في لفظين فإنه تحذف أولى المتفقتين، وتمد

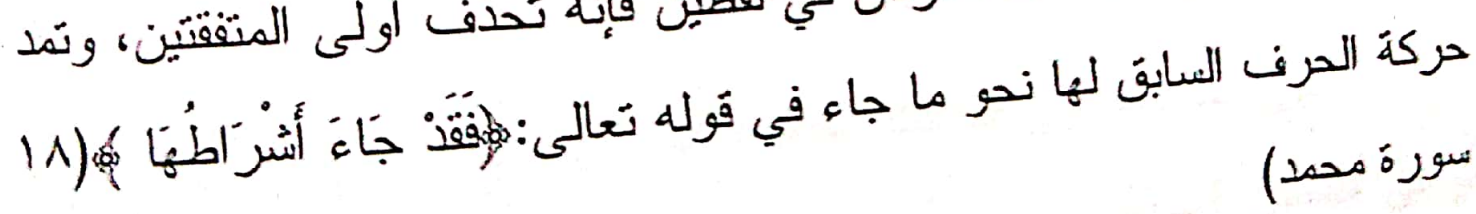
سورة محمدان

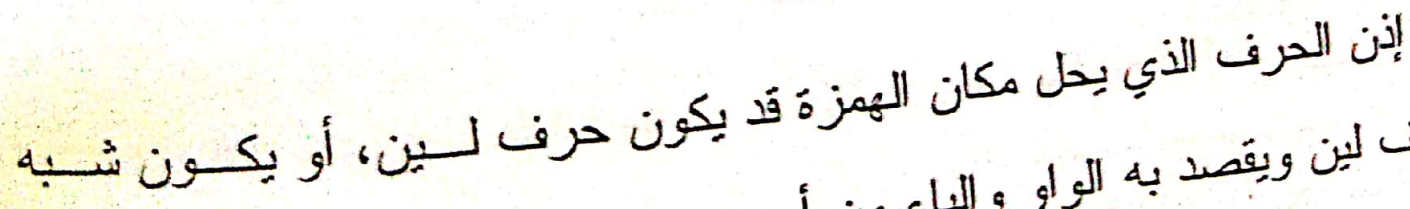

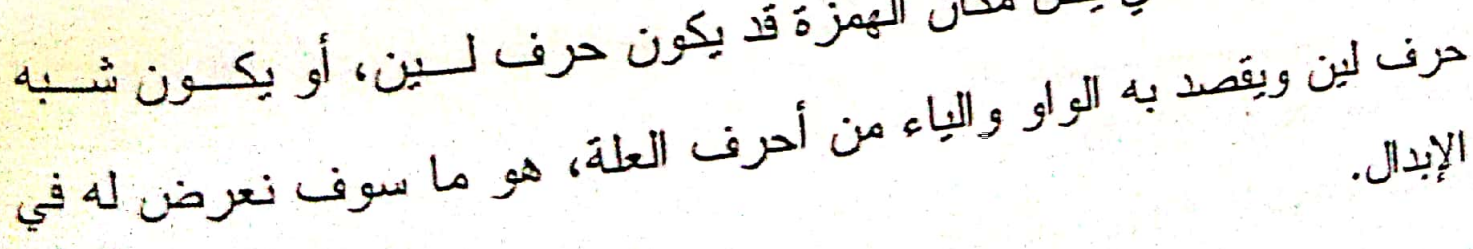


عند تو الي همزتين فإن الثانية منهما تبدل باءة أو واو"ا فرارأ من اجنماع

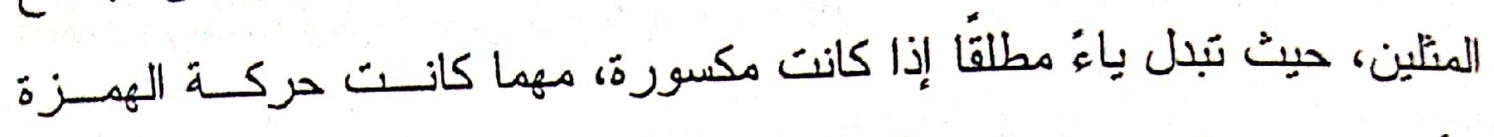

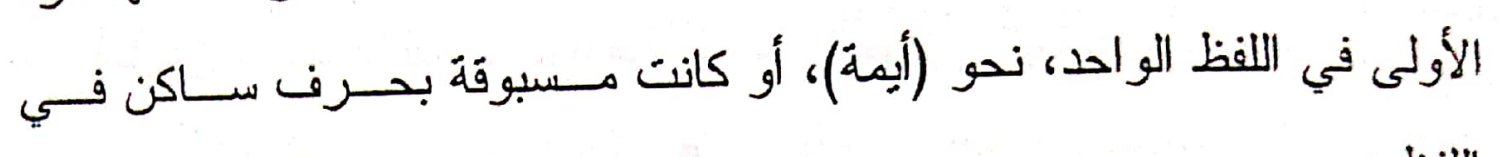
اللفظين.

وتبدل الهمزة الثانية المضمومة و المفتوحة ياء إذا كانت الأولى مكسورة، إنها نحو (إيم)، أما إذا كانت الهمزة الثانية مضمومة فتبدل واؤا سواء أكانت مسبوقة

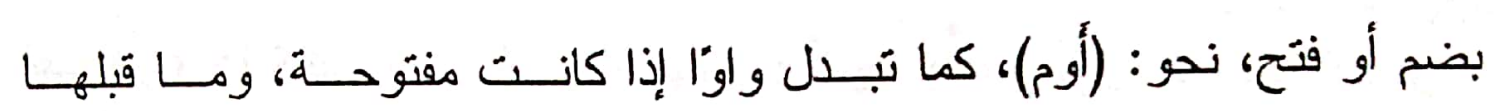

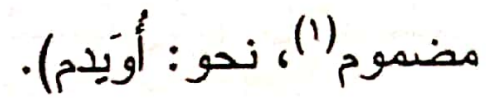
الإبدال لغير التخفيف:

يرى بعض العرب إيدال الهمزة حرفا آخر لغير التخفيف، و على ذلك أبدلها

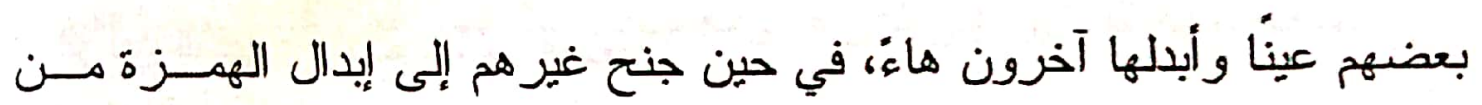

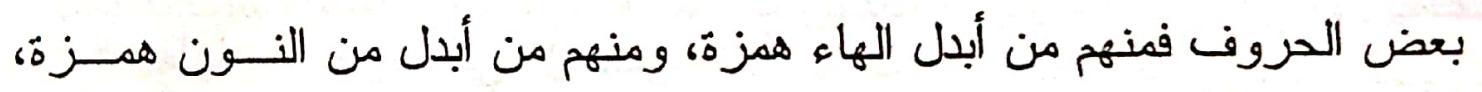
وبعضهم أبدل الواو همزة. أولا: إبدال الهمزة عينًا (العنعنة):

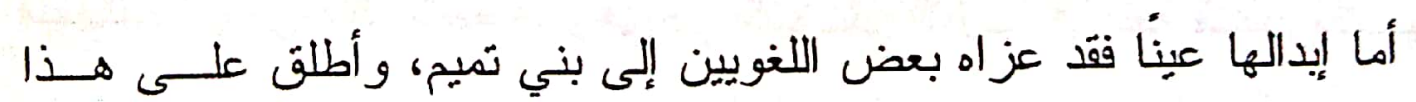
النوع من الإبدال (العنعنة). (1) شرح الثافية: ك/ 


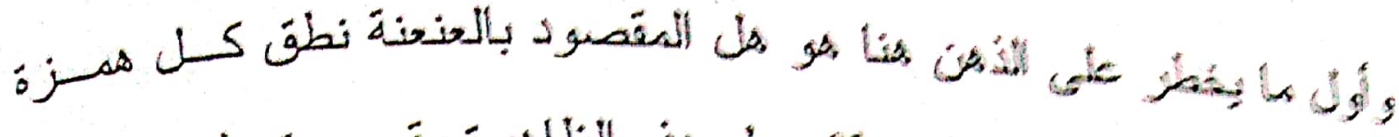

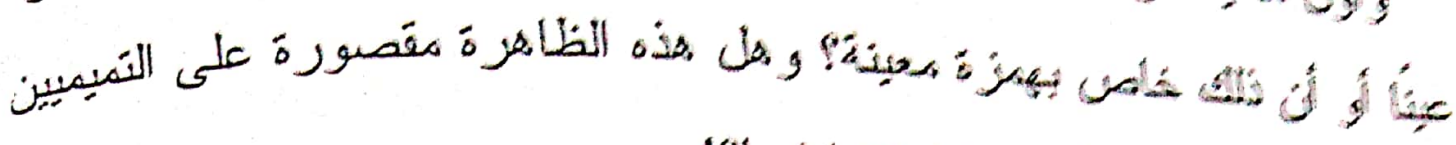

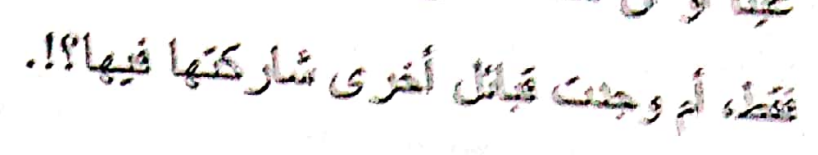

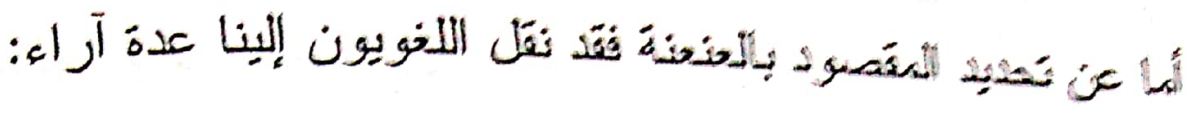

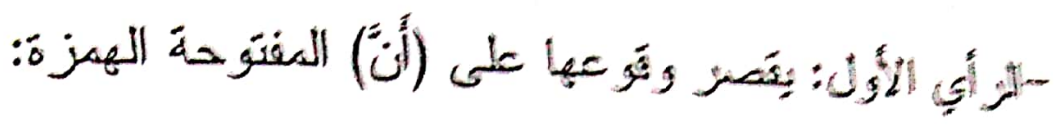

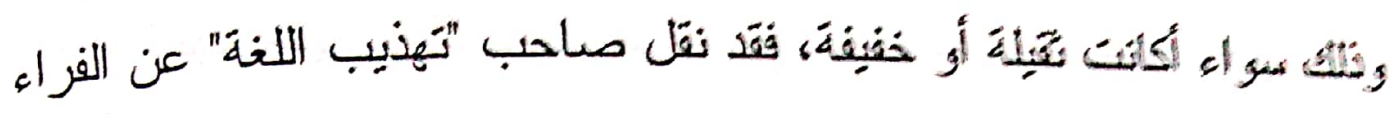

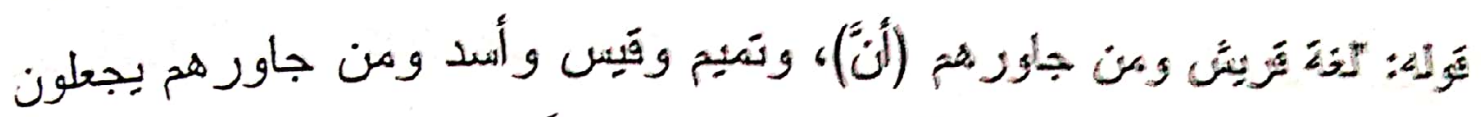

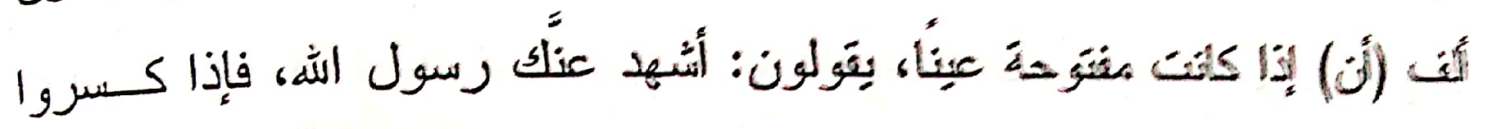
(1)

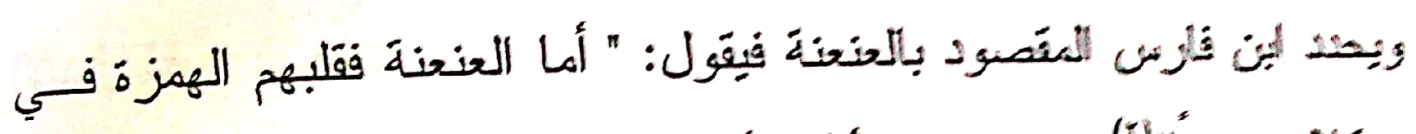

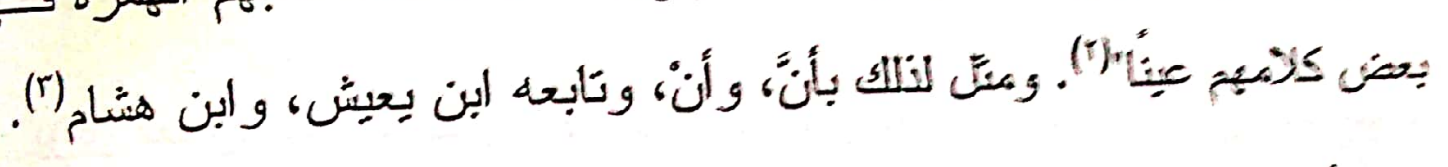

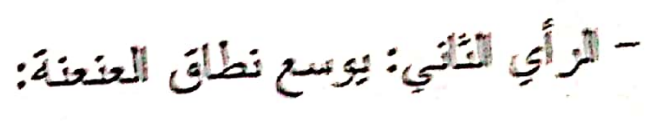

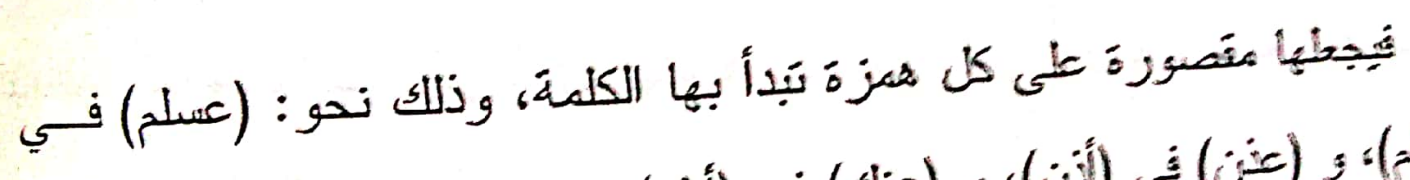

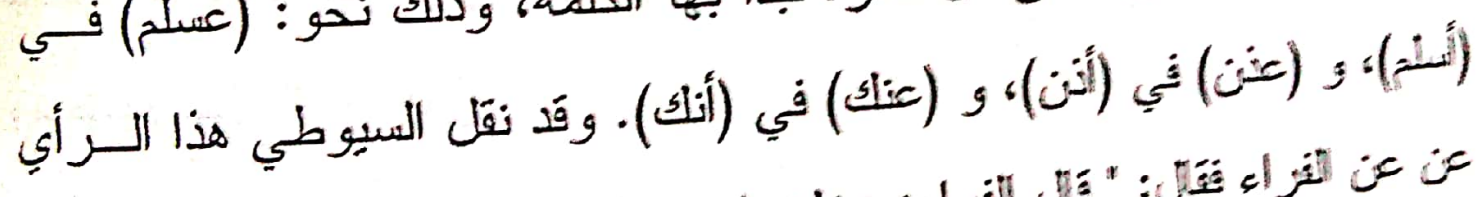

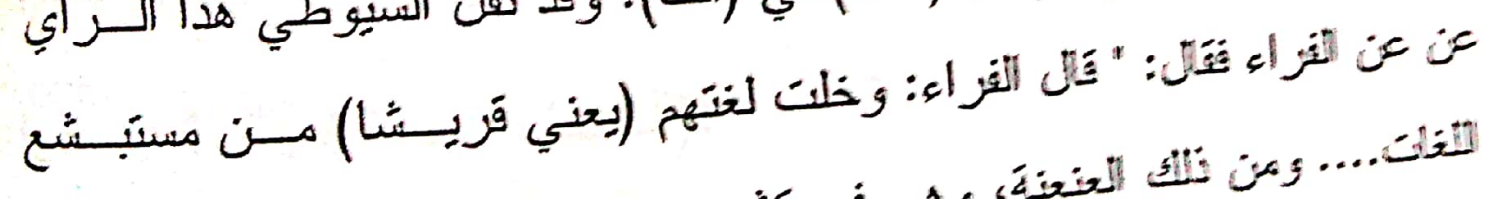

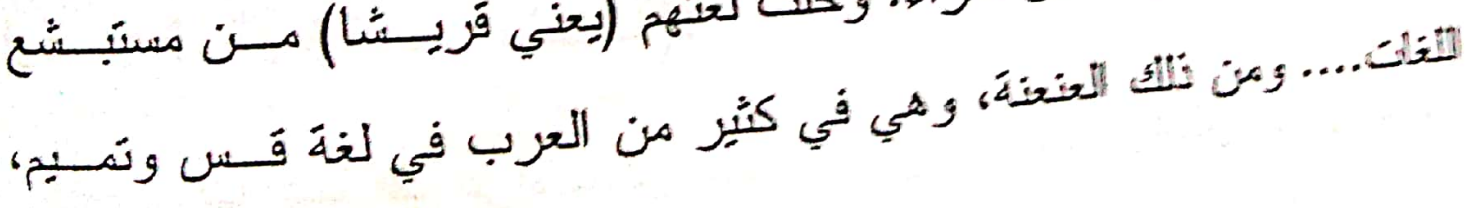

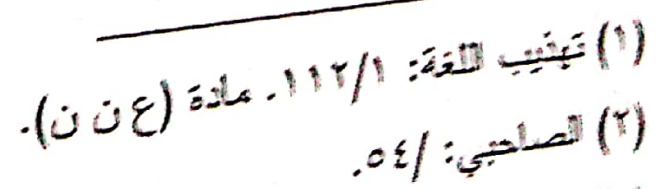
شا 

رتبعل الههزة المبدوء بها عينا فيقولون في أنك عنك، وفي أسلم عسلم، وفـي

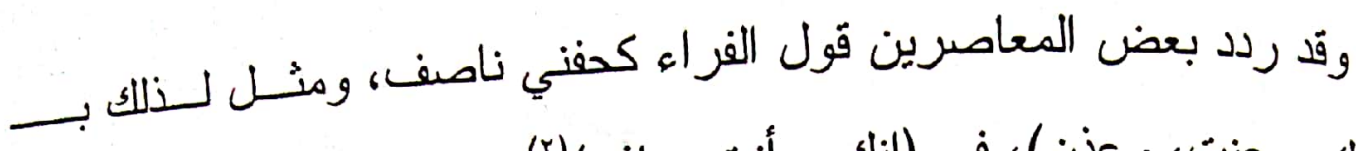

$$
\text { (عنك،، وعنت، و عذن)، في (إنك، و أنت، و إذن) (r). }
$$

وبالنظر إلى النصين السابقين المنقولين عن الفراء نجـــد بينهمـــا تناقـضـا و اضخا في تحديد المقصود بالعنعنة، فالنص الأول يقصر ها على( أن) المفتوحة الهمزة ثقيلة كانت أو خفيفة، بينما يوسعها النص الثاني فتشمل كل همزة مبلوء

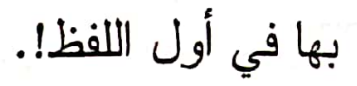

وقد حاول بعض المحدثين تفسير هذا التتاقض، حبث ذهب ضـــاحي عبـــ

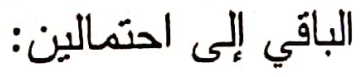

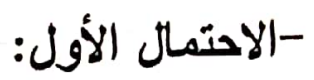

صحة نسبة النصين إلى الفراء، و أنه سجل كلا الــر أيين فــي مــؤلفين مختلفين وفي فترتين زمنيتين مختلفتين من حياته، فرجع في الثانية مصوبًا مــا دوَّنه في المرة الأولى، وليس ثمة دليل على نزجيح أحدها.

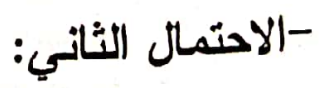

أن يكون أحد الناقلين: الأزهري أو السيوطي لم يتحر الاقة في النقـلـ، وفي هذه الحالة ربما بكون تحديد العنعنة الــذي ورد فـي كتــابي الـسيوطي

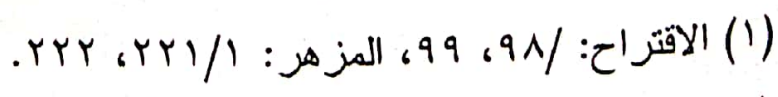

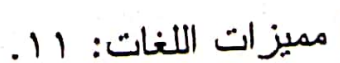


(الاقتز اح، والمزهر) هو للسيوطي نفسه ذكره بعد أن نقل كـلام الفـــرأ دون

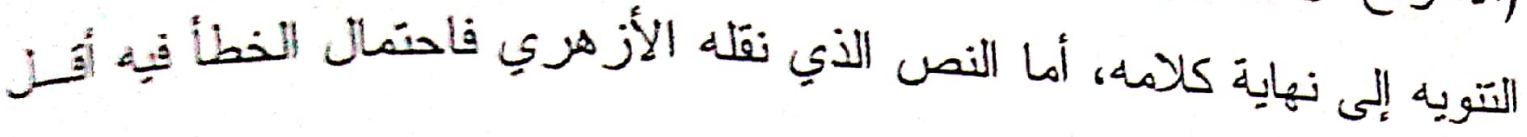

من الثاني (') - الرأي الثالث: قلب الهمزة عينًا مطلقا:

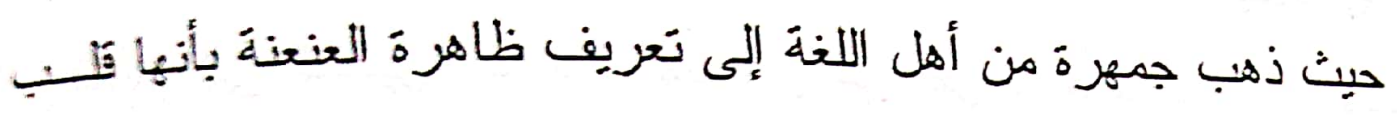

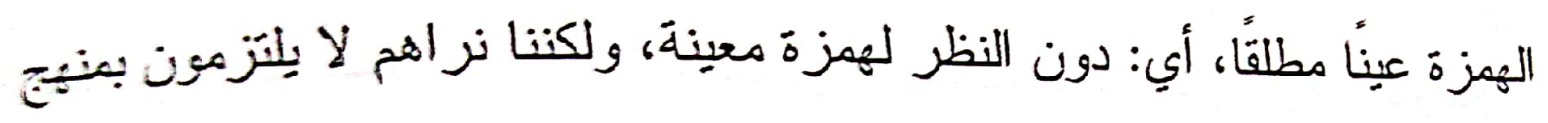
في الاسنكلال على رأيهم. ويمكن تقسيم أصحاب هذا الاتجاه إلى طائفتين: - الطائفة الأولى: تكتفي بالاستكلال بشو اهد تشتمل على (أن)، سواء أكانتَت تهبلة أو خفِفة فقط، وهو ما نجده عند الخليل في معجمه، حيث أورد قَول شاعز بيني تميَم:

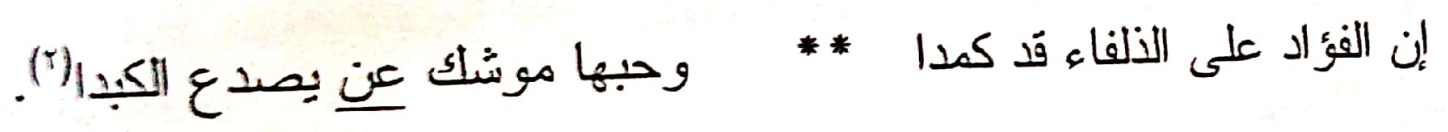

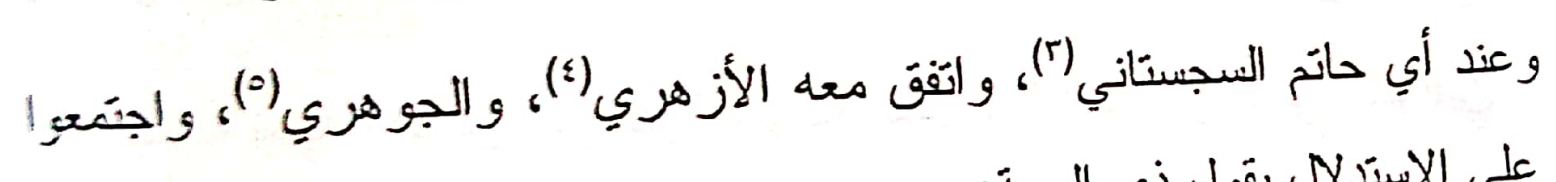

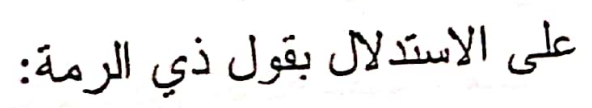

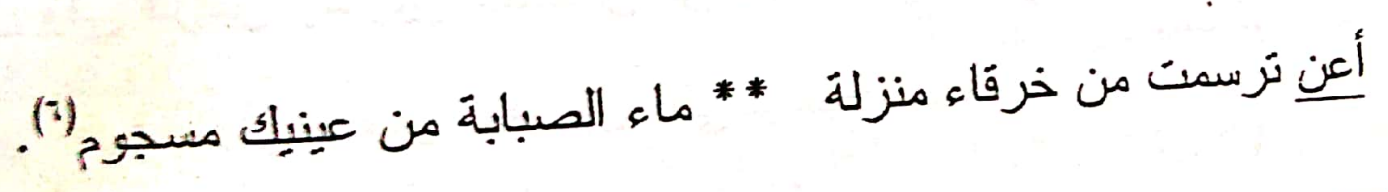

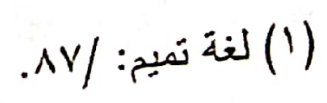

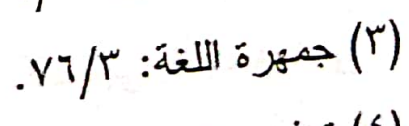

$$
\begin{aligned}
& \text { ( ) نهذيب اللغة: }
\end{aligned}
$$

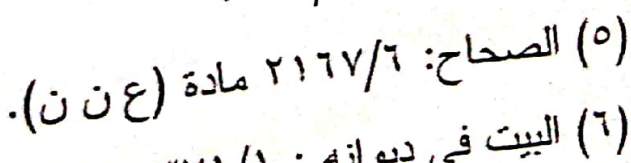

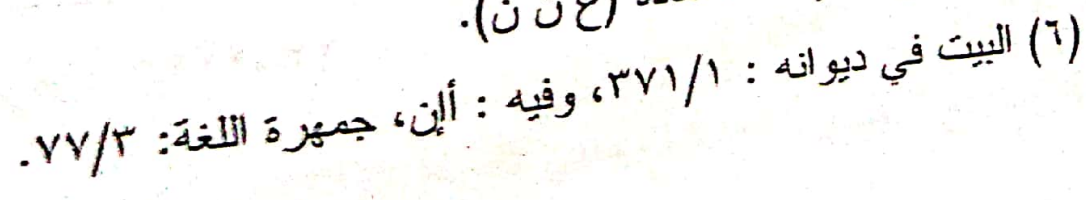


كا نجد ذلك عند ابن سيده الذي استشهد بقول الشاعر:

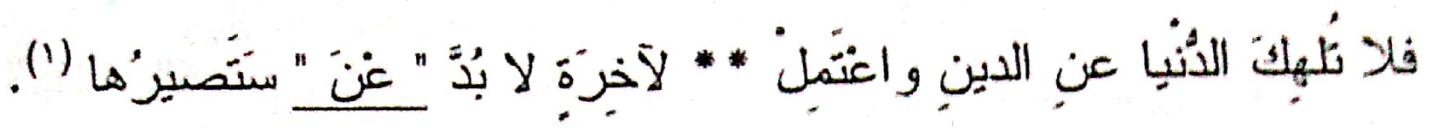

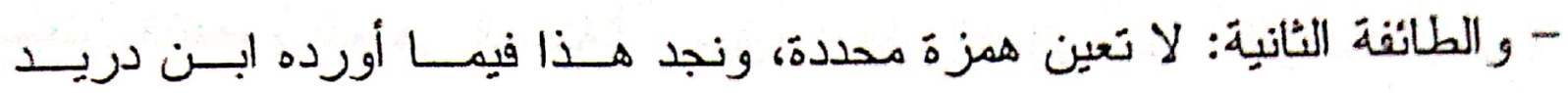
و الزبيدي، فابن دريد يقول: "العنعنة حكابة كلام نحو قولهم عنعنة تميم، لأنهـ

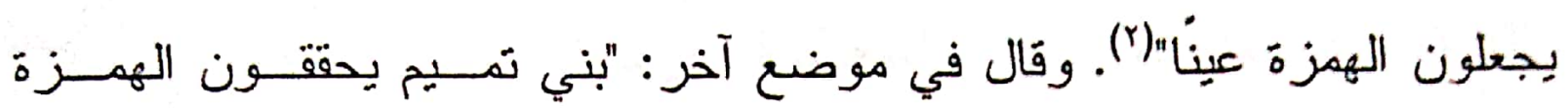

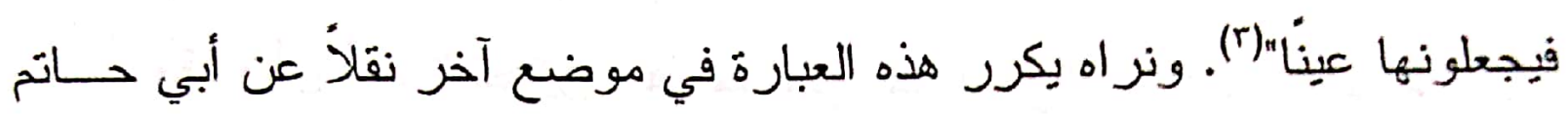

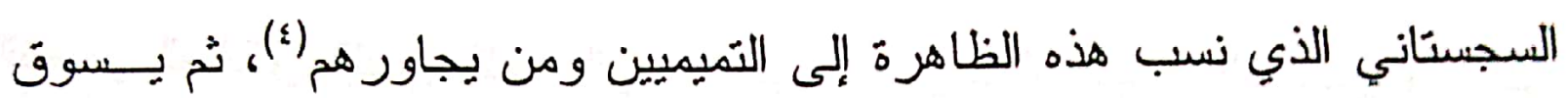

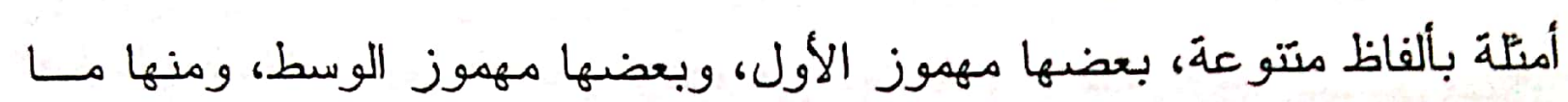

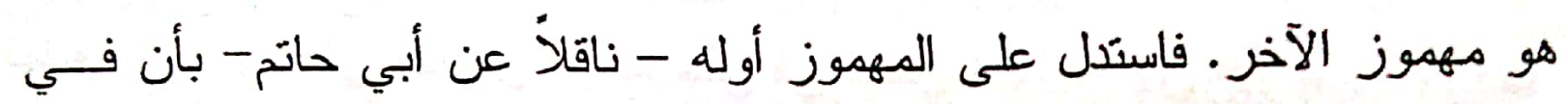
قول الشّاعر:

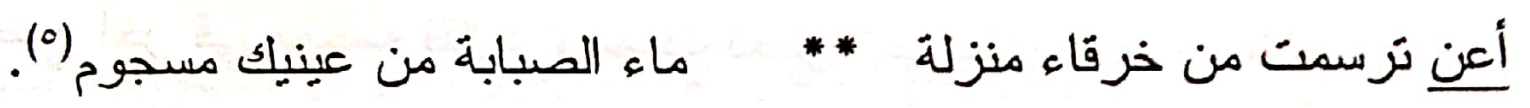

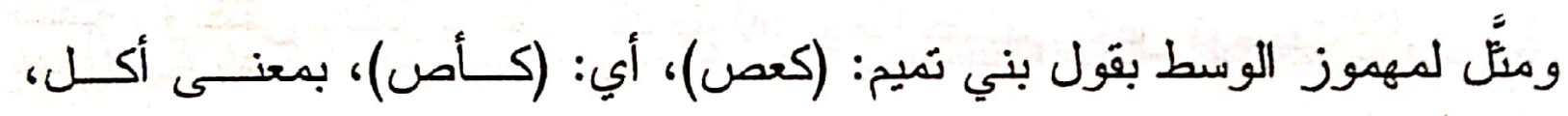
و استشهد للمهوز الآخر بما نقله عن بني تميم من قولهم: "هذه خباعنا، بريدون

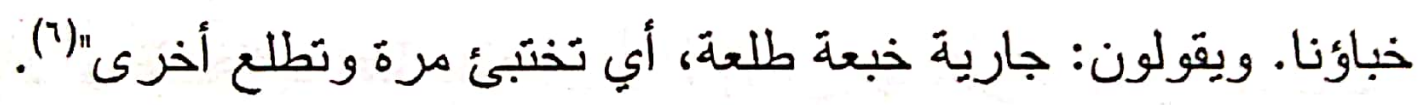

$$
\begin{aligned}
& \text { (1) البيت في المحكم: /9/ ع. }
\end{aligned}
$$

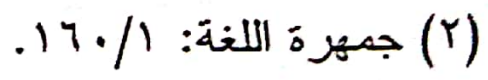

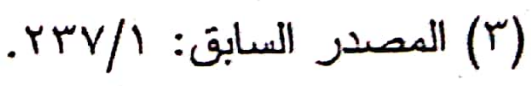

$$
\begin{aligned}
& \text { (ع) المصدر السابق: ب/ } \\
& \text { (0) سبق الاستدلال به. } \\
& \text { (T) جمهزة اللغة: }
\end{aligned}
$$




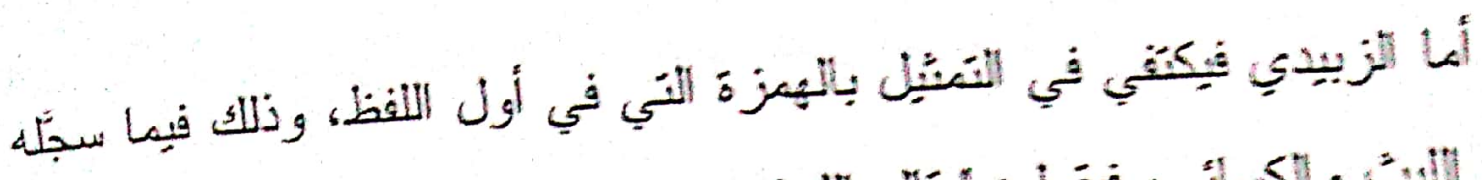

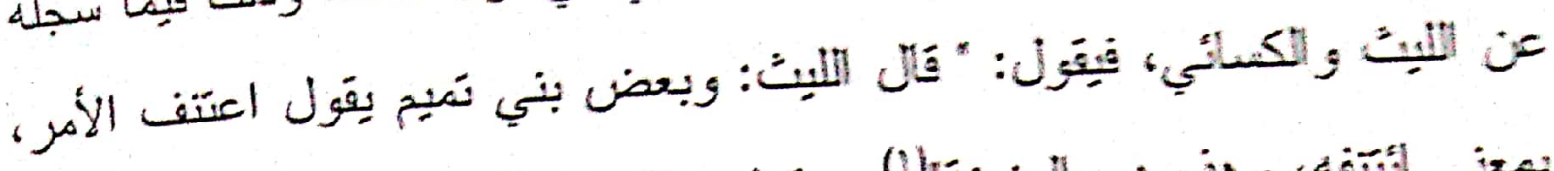

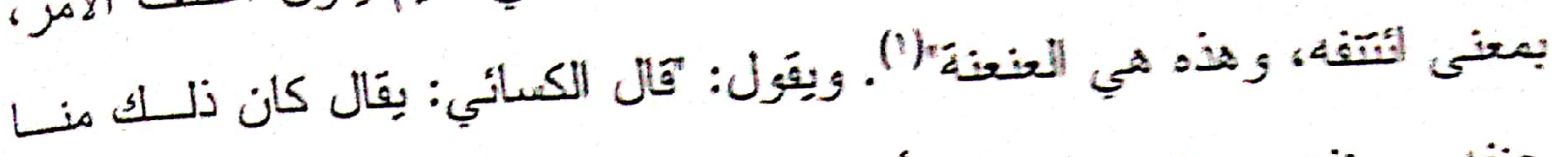

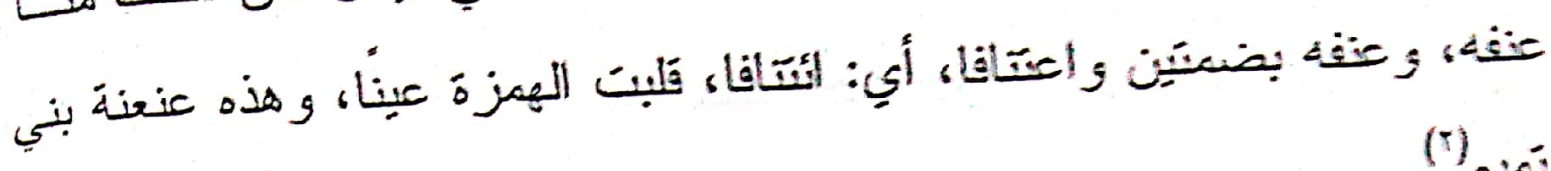
تصنيخ (1)

وقدَ رأى أحد المحثين وهو ضاحي عبد الباقي (م) أن كلمة العنعنة فـي

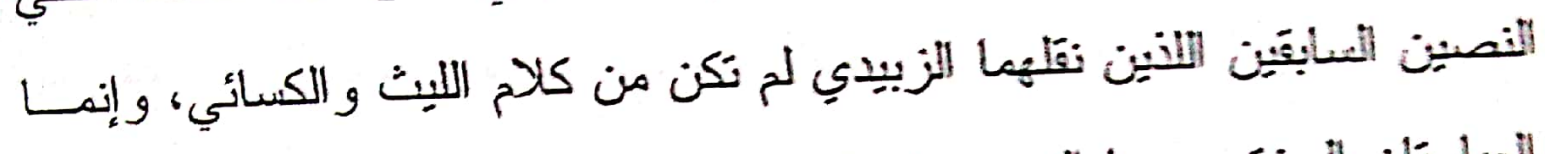

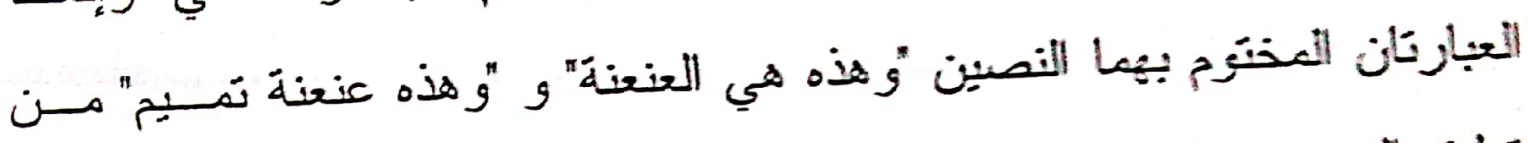

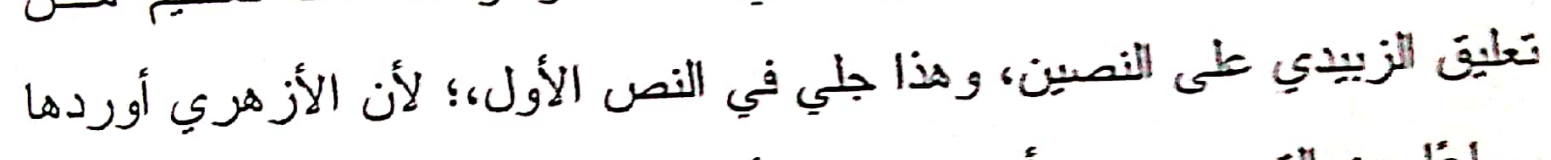

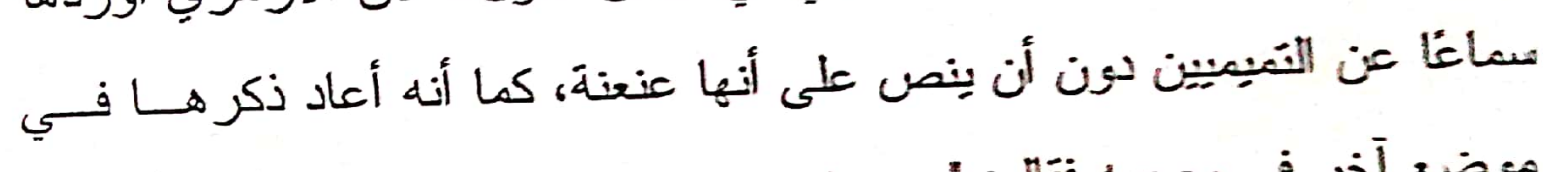

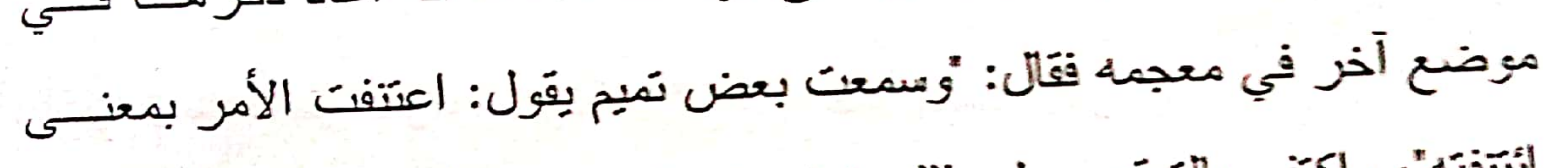

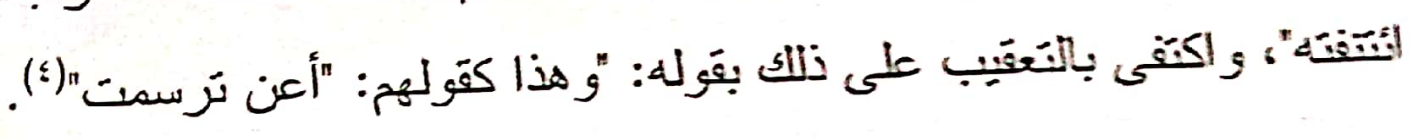

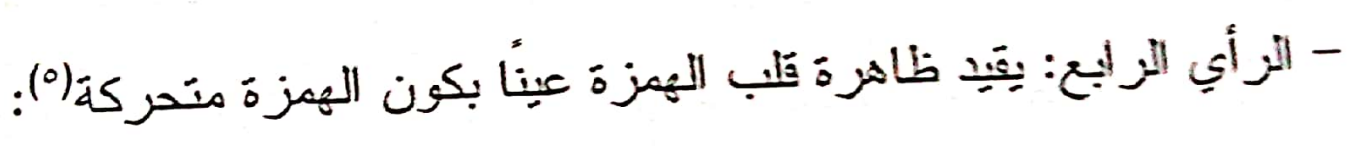

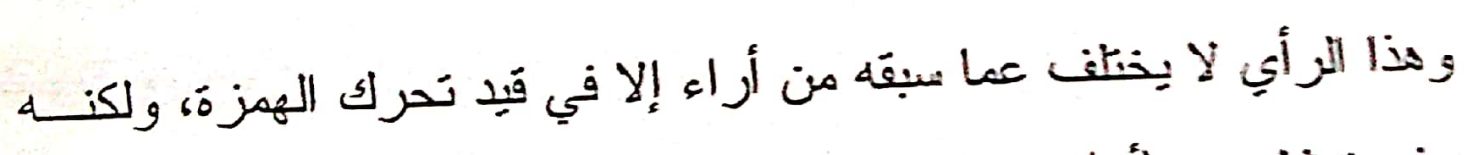

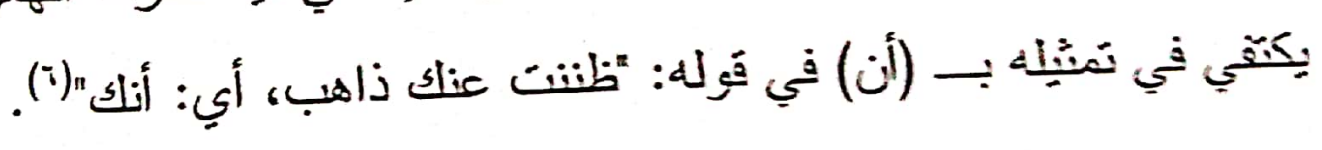

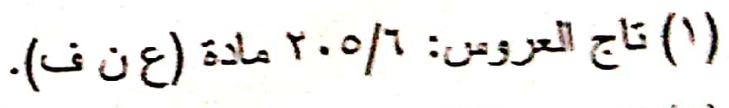

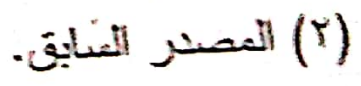

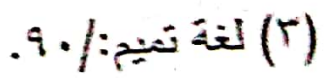

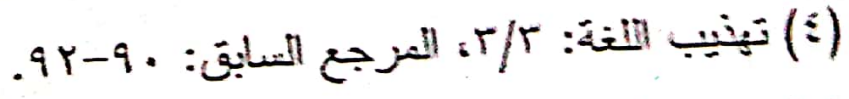

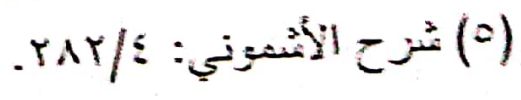

$$
\begin{aligned}
& \text { الأصنر المسائ. }
\end{aligned}
$$




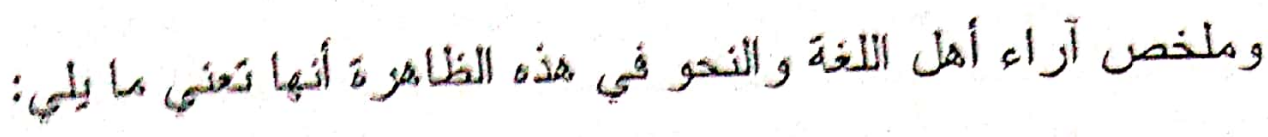
1- قلب همزة أنَّ، وأن المفتوحتبن عينًا. Y- قلب الهمزة المبدوء بها سو اء أكانت مفتوحة أو مكسورة. r- قلب كل همزة دون اعتبار لهوقحها أو حركتها. ع - علب الهمزة المتحركة، عينًا.

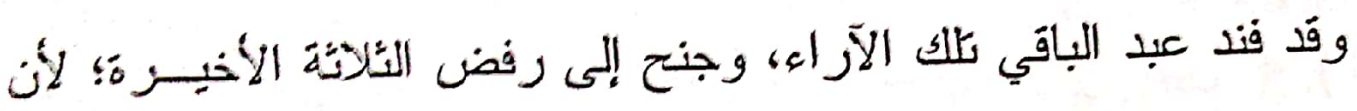

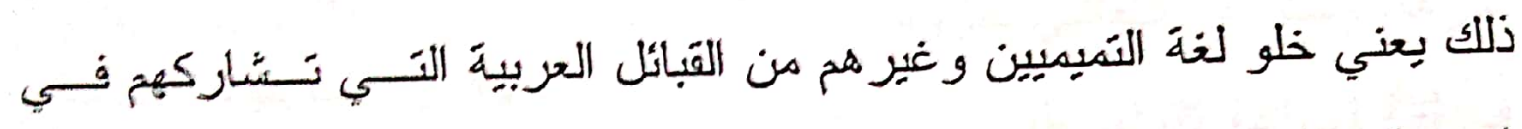

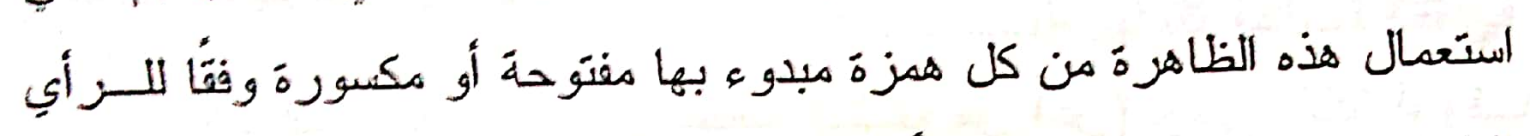

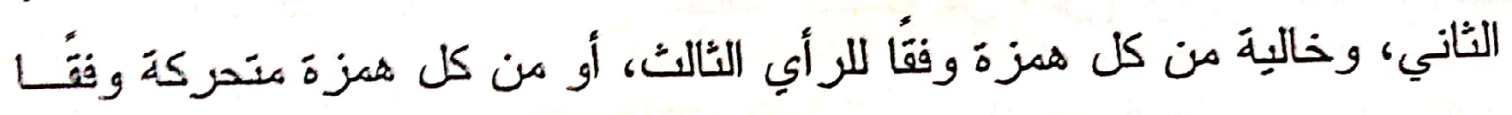

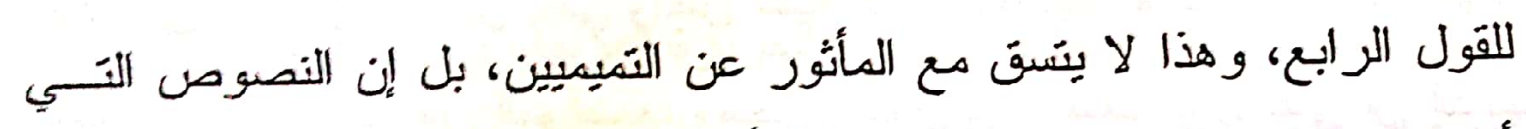

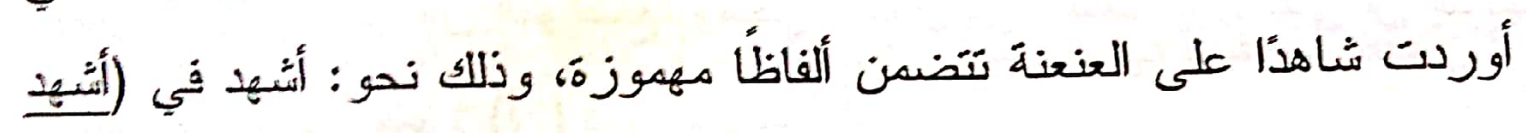
عنك رسول الله)، وخرقاء وماء في قول الشَاعر:

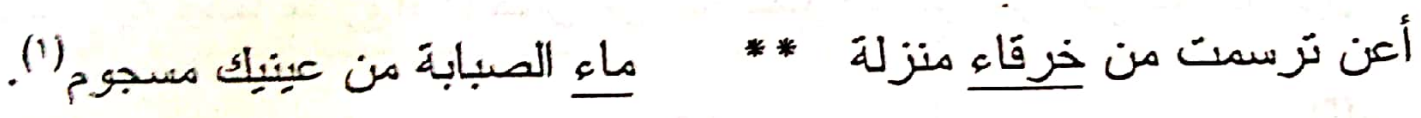
وكذلك الألفاء في قَول الآخر:

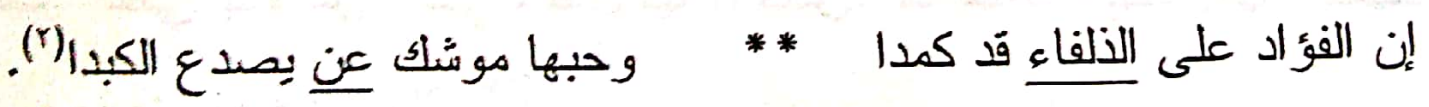




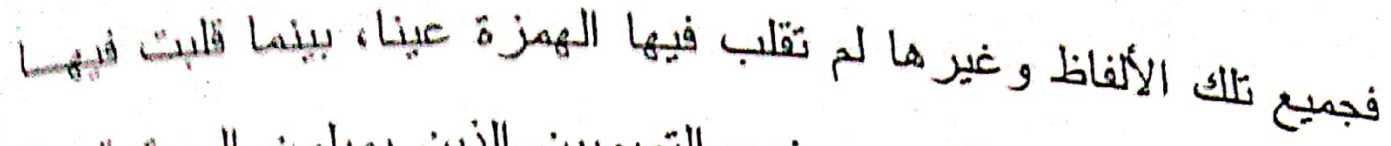

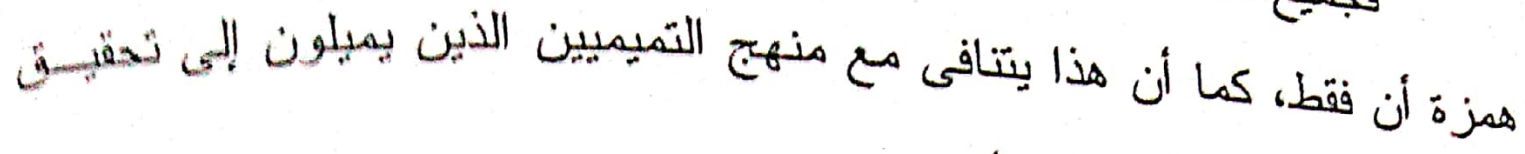

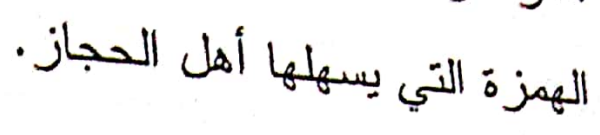

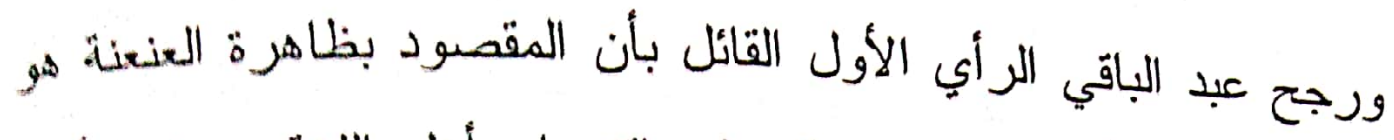

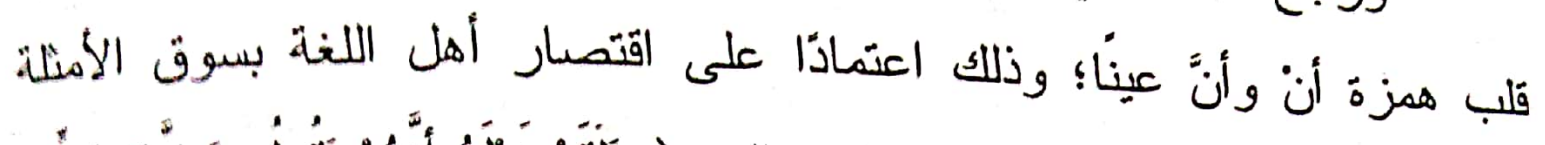

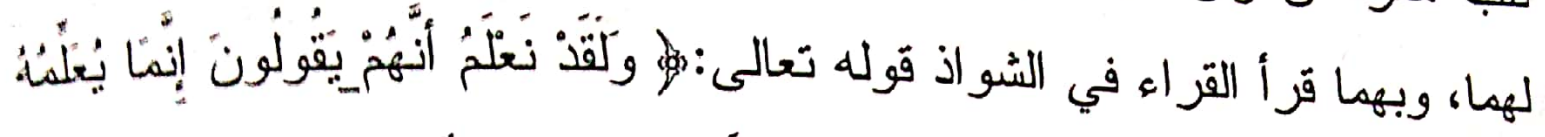

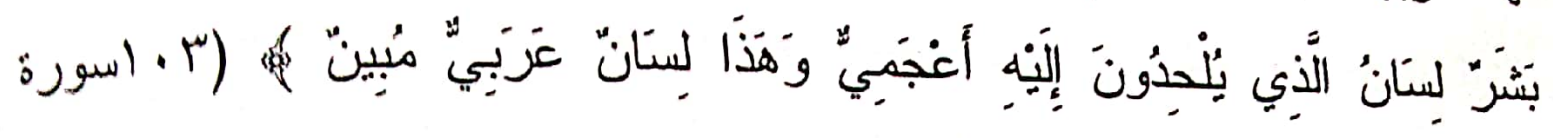

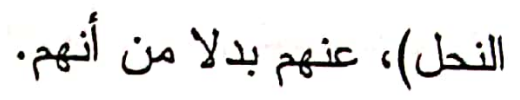

كما أيد ترجيح رأيه بأن العنعنة المشتقة من (عن) توحي بذلك (1)، وفــــ تتبه إلى ذلك من قَبل ابن جني ونص عليه فقال: "وقولهم عنعنة مشتق من قولهم (عن عن) في كثير من المواضع، ومجيء النون في العنعنة يدل على أن إيدالهم

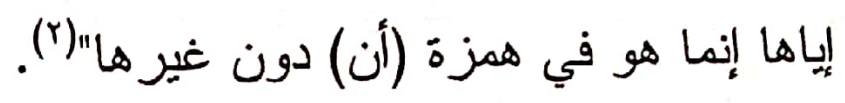
ويدعم رأيه أيضنا ما رواه الأخفش من أنه سمع أعر ابية من بني كلاب ثقول:

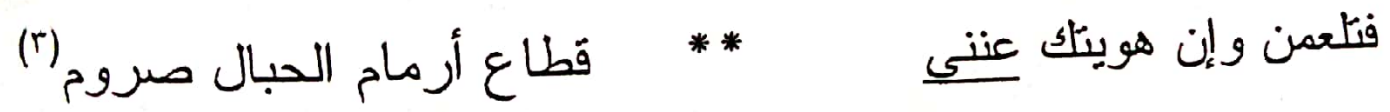
فقالت: "عنني" بدلا من " أنني"، فقال لها الأخفش: "ما هذا؟! فقالت: هذه عنعنتا، وفي رواية: عنعنة بني فلان"(\{).

$$
\begin{aligned}
& \text { (1) لغة تميح:| • (1) }
\end{aligned}
$$

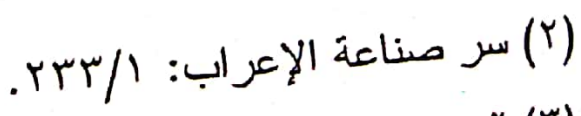

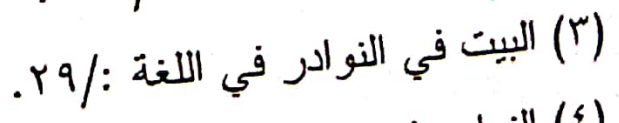

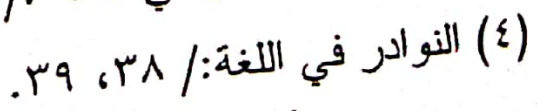




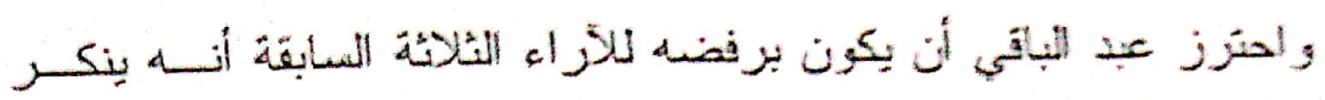

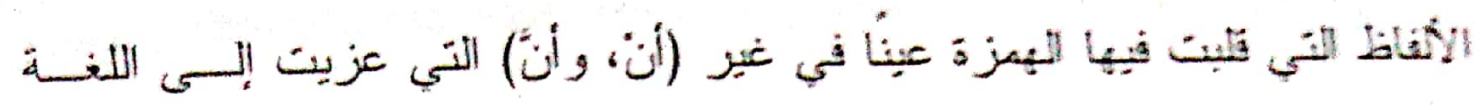

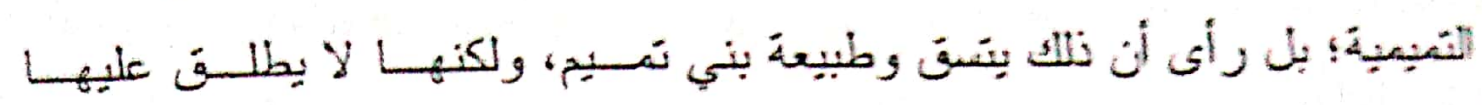

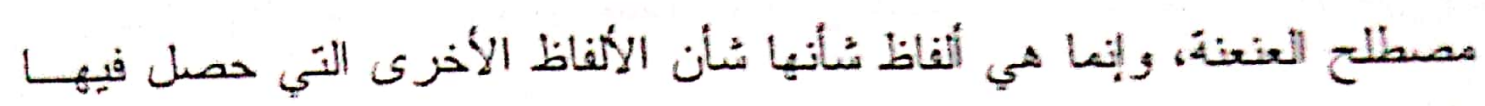

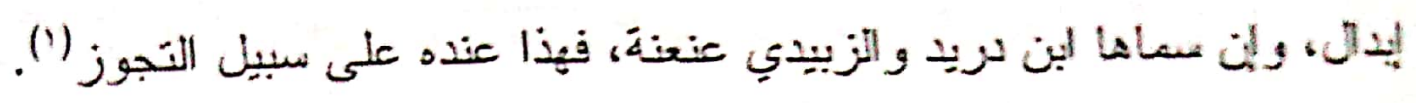

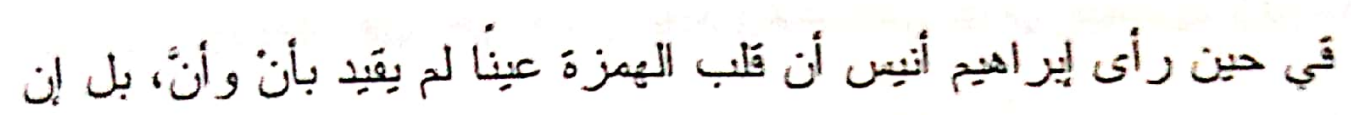

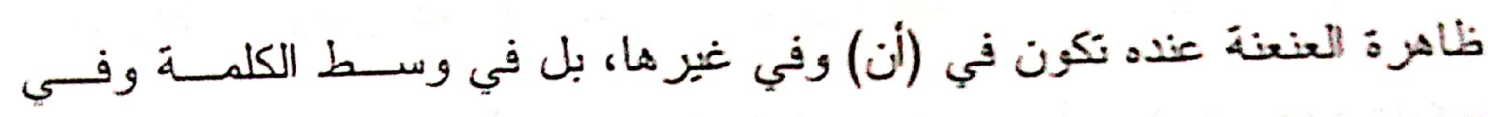

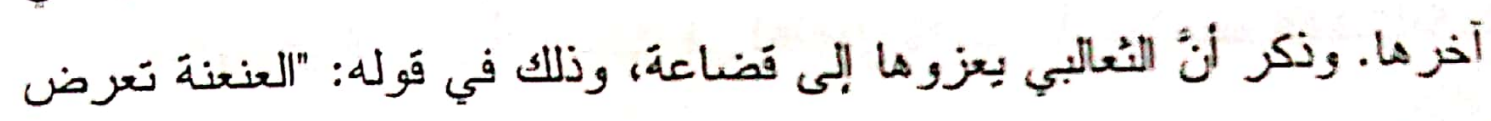

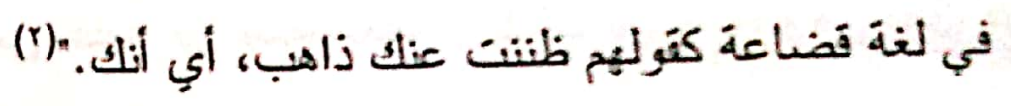

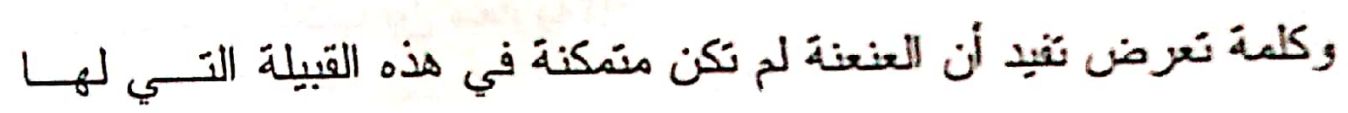

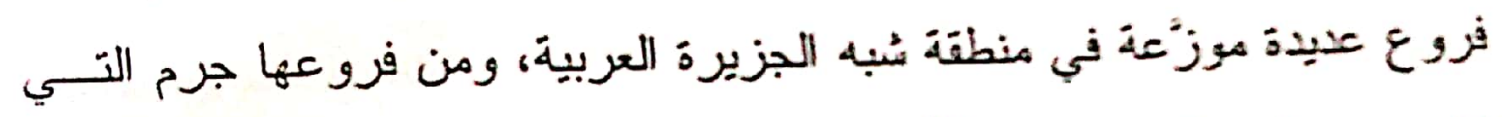

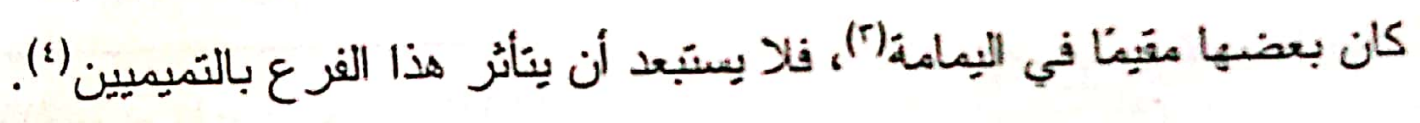

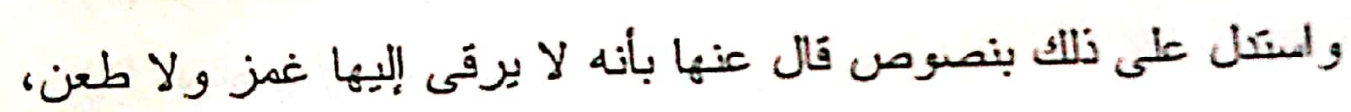

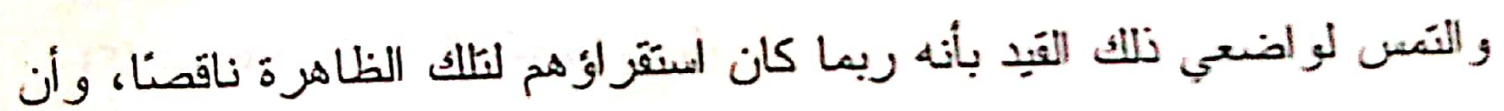

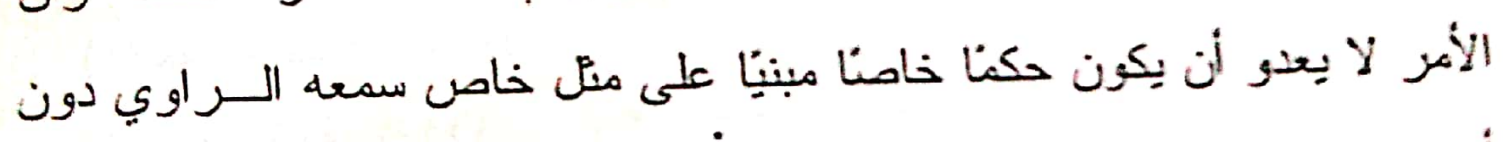

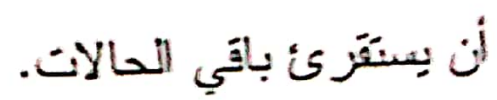

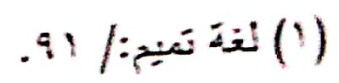

$$
\begin{aligned}
& \text { A. V | (Y) }
\end{aligned}
$$

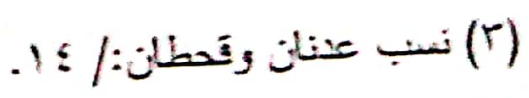

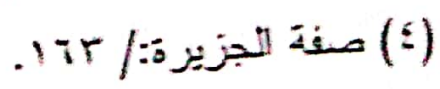


أما عمن نطق بهذه اللغة فنجد أن معظم أهل اللغة اقتصروا على نسبنها

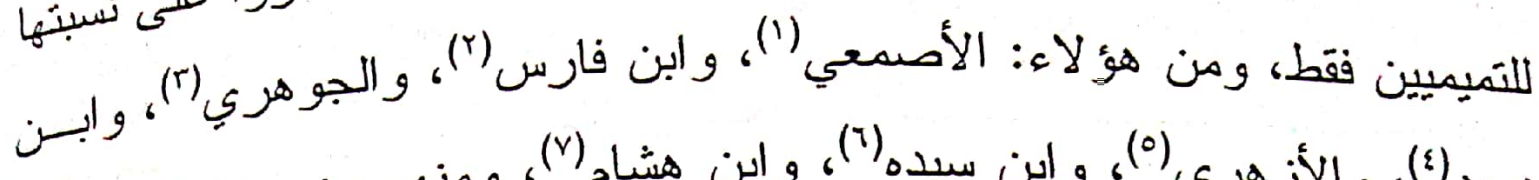

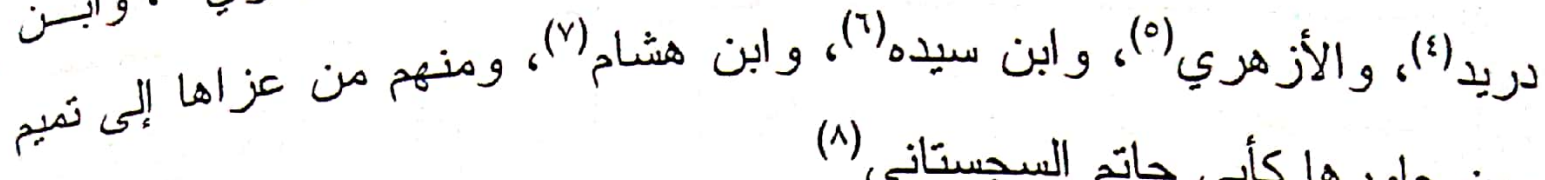
ومن جاور ها كأبي حاتم السجستاني (^ان

ومنهم من عز اها إلى تميم وأسد كأبي جعفر النحاس، و الزمخشري(9).

و عزاها السيوطي نقلا عن الفر اء إلى قِيس وتميم (·").

وزعم البعض أنها كانت في لغة بني كلاب(")'، و لا نعلم إذا مسـا كسان المقصود بكلاب بطن من عامر بن صعصعة، أو كلاب بن مرة، وهي بطن من قريش، أو كلاب بن معاوية؟!|(IY)

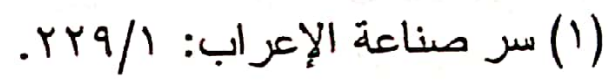

$$
\begin{aligned}
& \text { (Y) }
\end{aligned}
$$

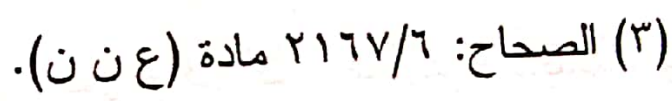

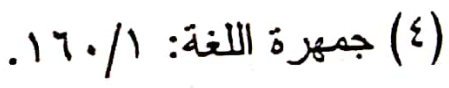

$$
\begin{aligned}
& \text { (0) تهزيب اللغة: 111/1) } \\
& \text { (7) (7) (7) المحكم: (1) } \\
& \text { r مغني اللبيب: (V) }
\end{aligned}
$$

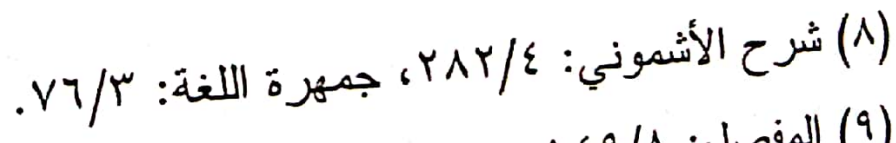

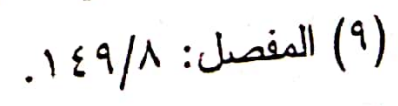

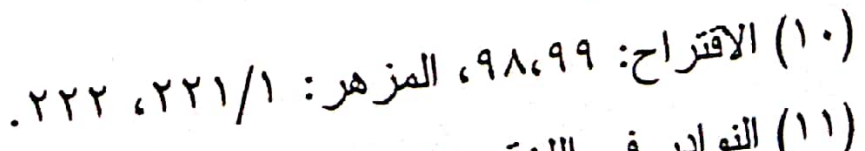

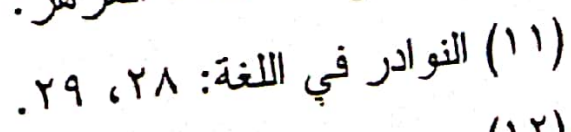

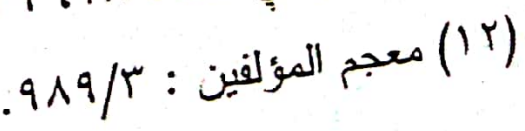




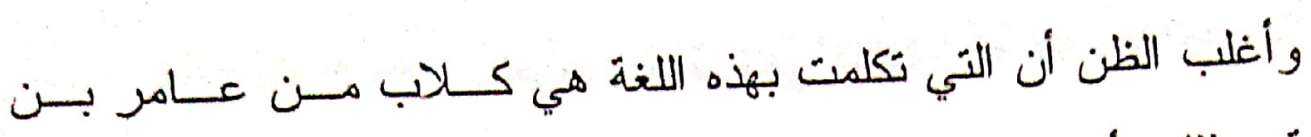

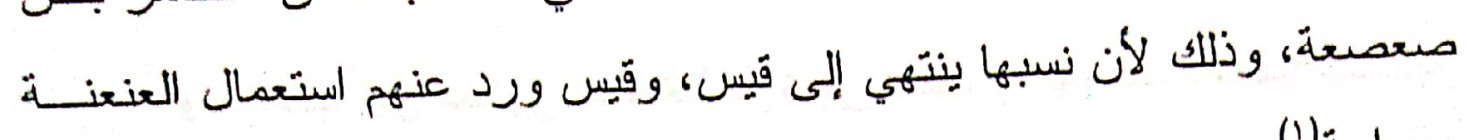
صر احة')

وتشير النصوص التي تم الاستشهاد بها على هذه الظاهرة أن بعضصها

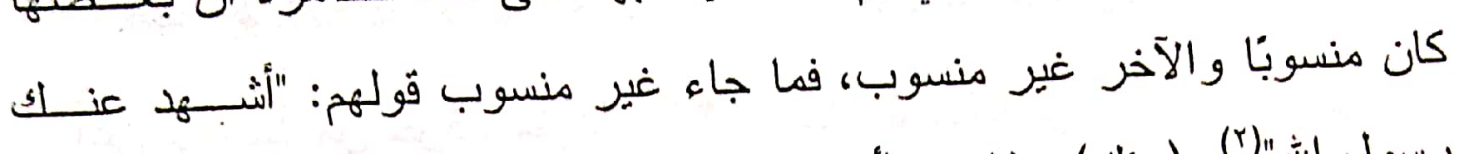

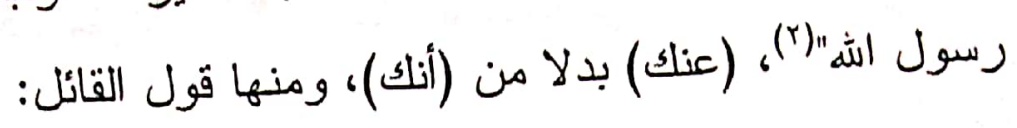

فلا تلهاك الدنيا عن الدين واعتمل ** لآخرة لابد عن ستصير ها(ت).

$$
\text { باستخدام (عن) بدلا من (أن). }
$$

وقد استّل ابن سيده بهذا البيت على نسبة العنعنة إلى التميميين، إلا أنه

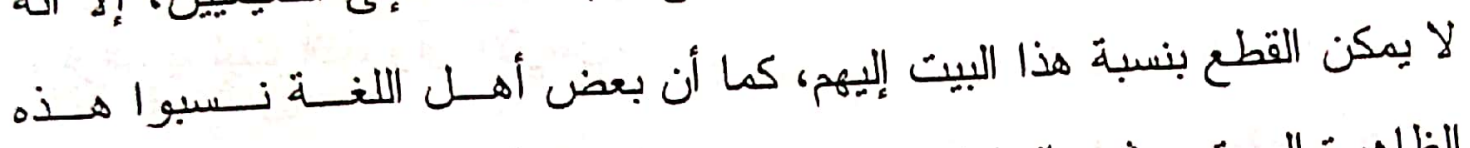

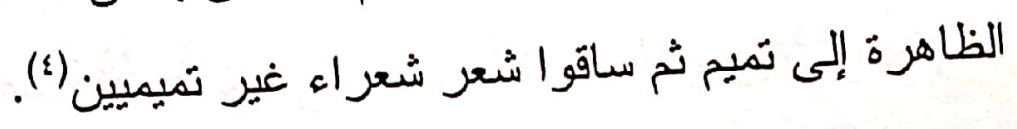

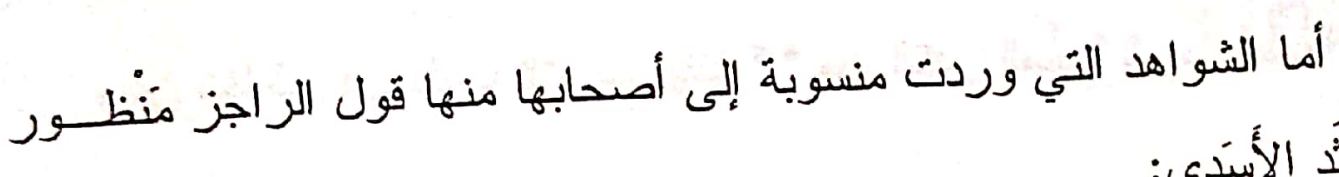
بن مرَتَّْ الأسَدَي:

$$
\begin{aligned}
& \text { نَعْرَضَتَتْ لِي بمكَانِ حِلِّ }
\end{aligned}
$$

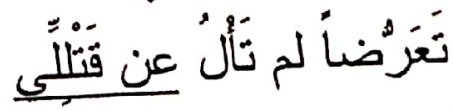

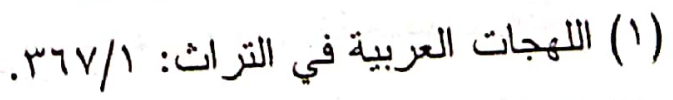

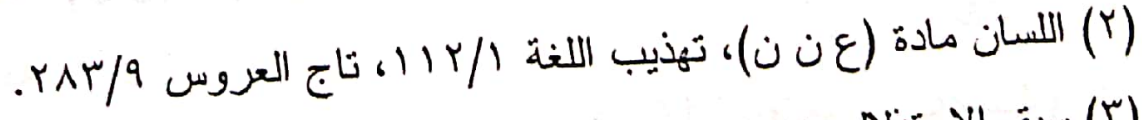

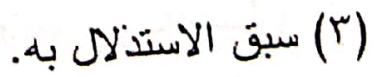

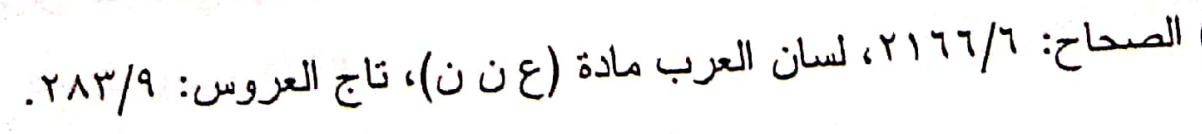




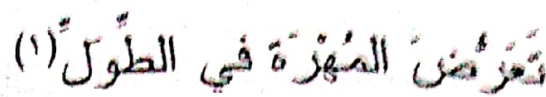

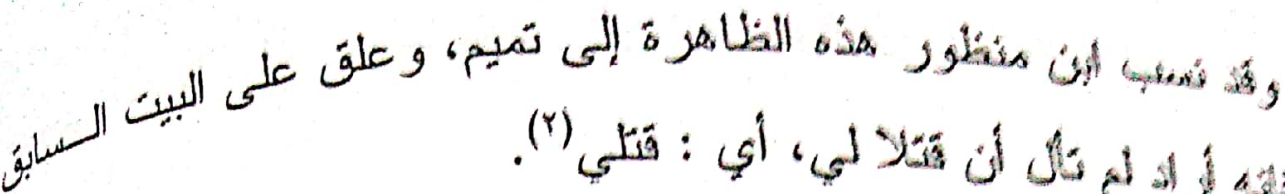

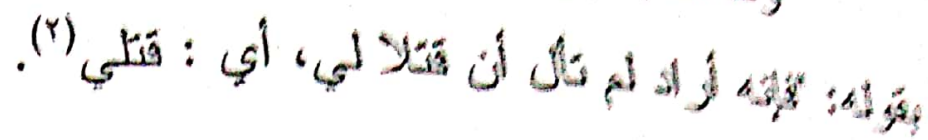

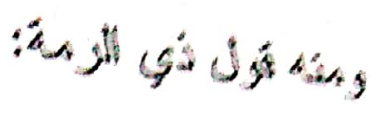

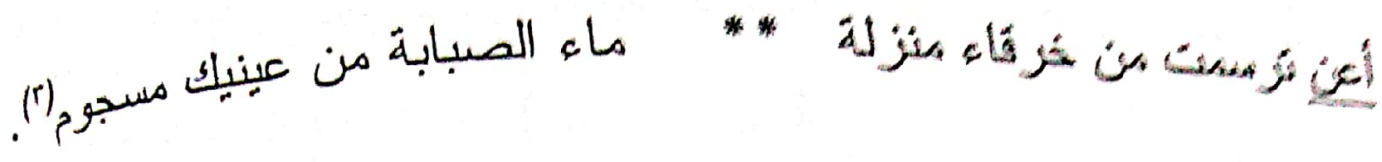

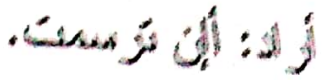

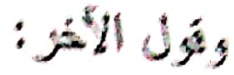

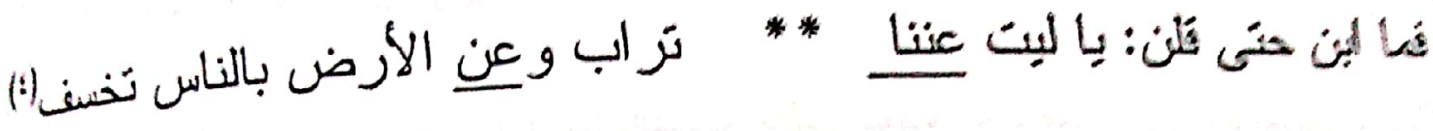

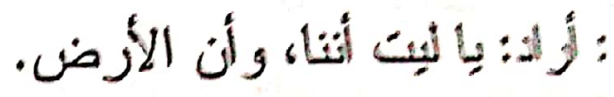

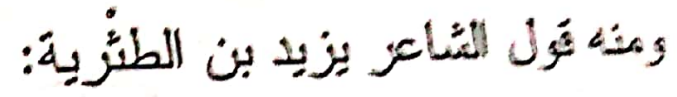

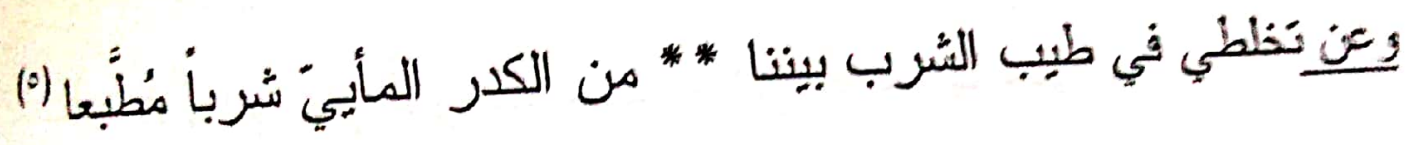
ألا: والن تخلطي.

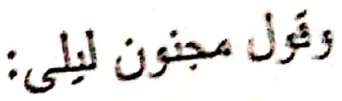

$$
\begin{aligned}
& \text { (1) الزرجز في الصاحبي:| ع ب، لسان العرب، مادة (أن ن)، و. (ط ول). }
\end{aligned}
$$

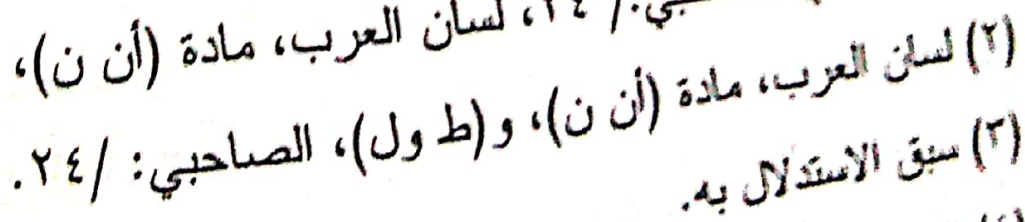

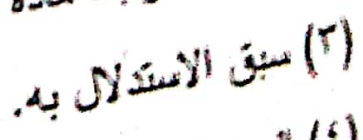

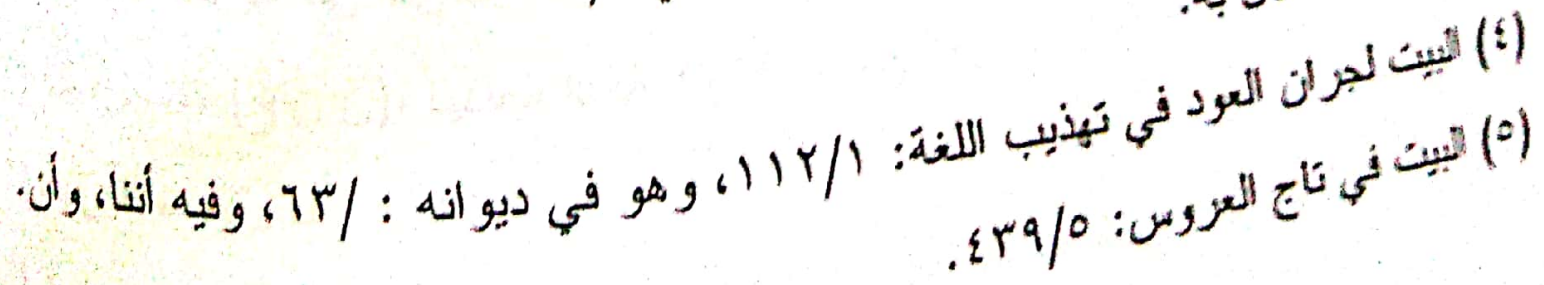


سوى عن عظم الساق منش دقيق (1)

** فيناش عيناها وجيدش جيدها

$$
\text { وقول أراد: سوى أن، }
$$

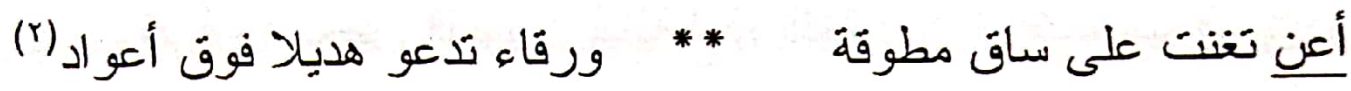

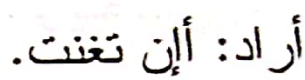

و إذا كانت بعض هذه الشواهد قد جاءت منسوبة لأسد وبعضها لتميح أو

لقيس فإن هذا يؤكد أن هذه الظاهرة ليست مقصورة على قبيلة تمـيم وحــدها،

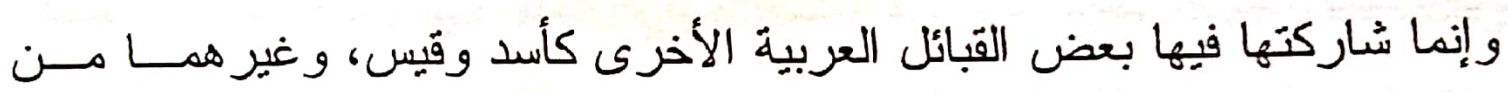

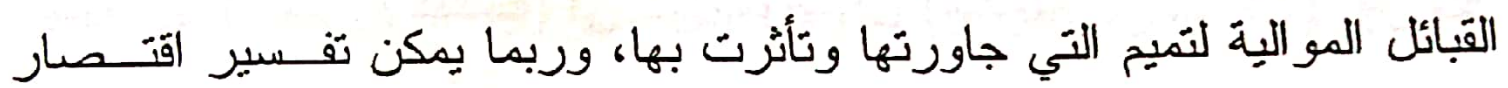
بعض أهل اللغنة نسبة العنعنة إلى تَميم فقط مرده إلى أن التميميين كانوا يشكلون

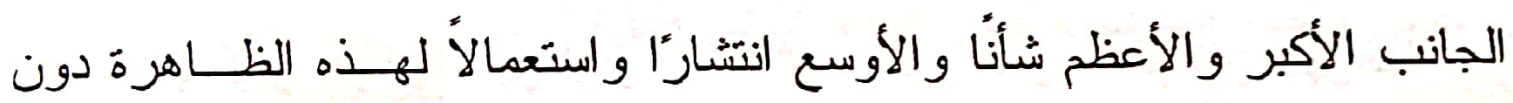
غير هم (r)

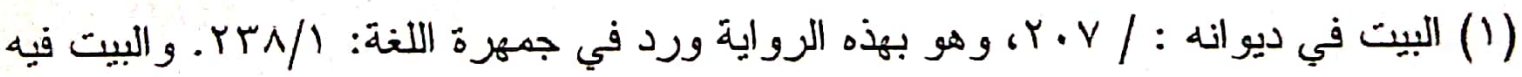

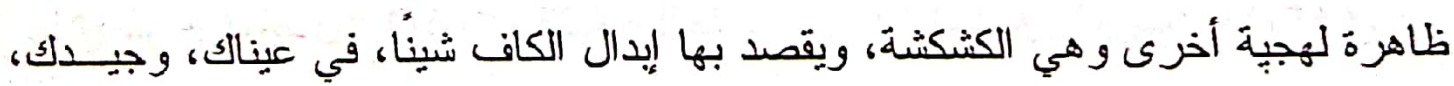
ومناك.

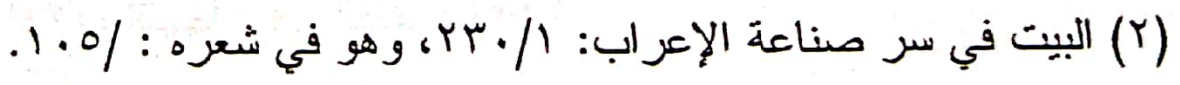

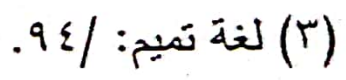




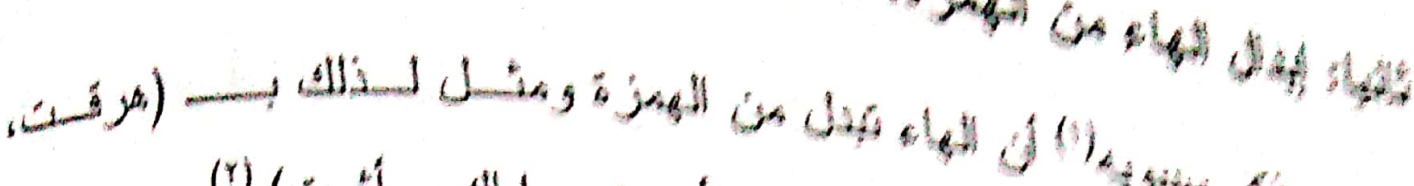

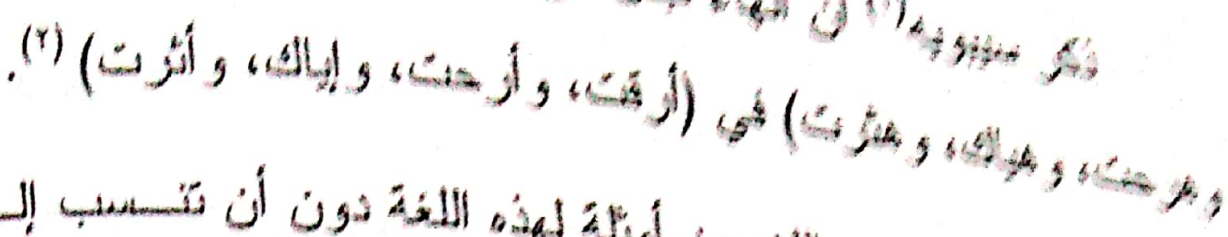

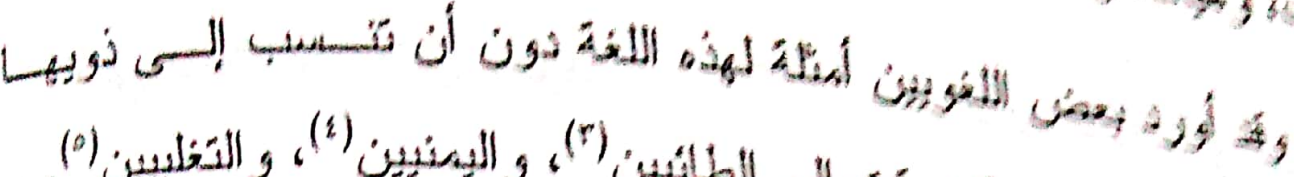

,

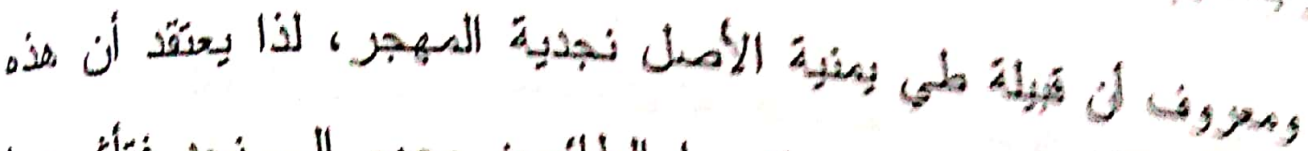

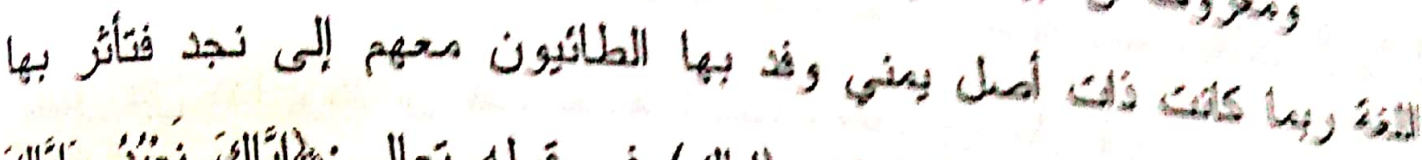

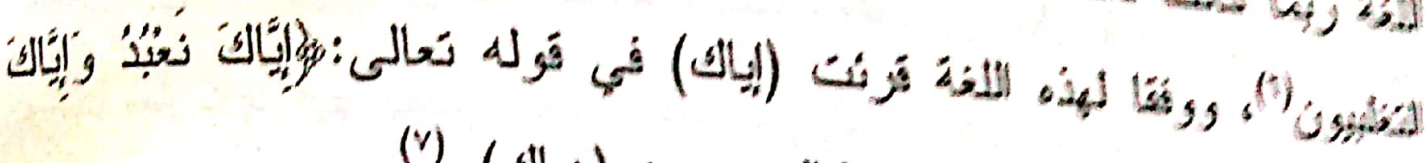

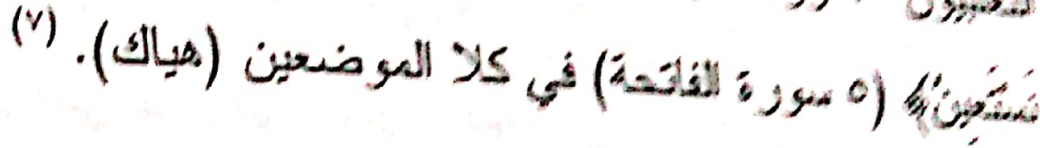

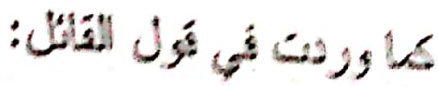

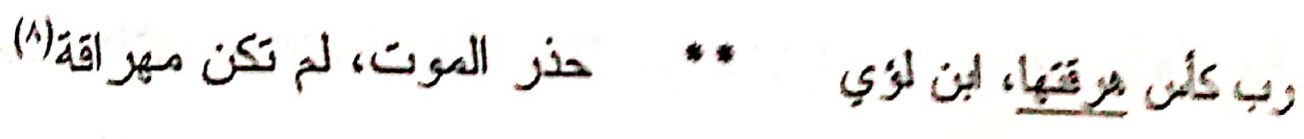

$$
\begin{aligned}
& \text { YTN/0, \&/T: }
\end{aligned}
$$

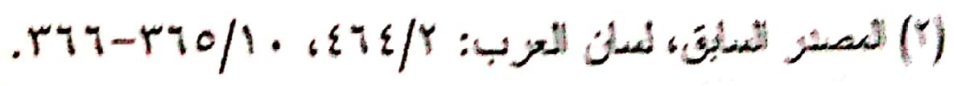

$$
\begin{aligned}
& \text { (1) }
\end{aligned}
$$

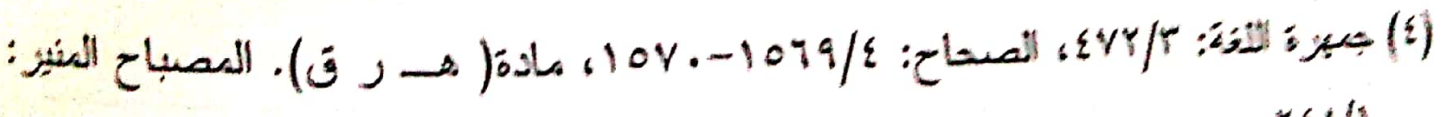

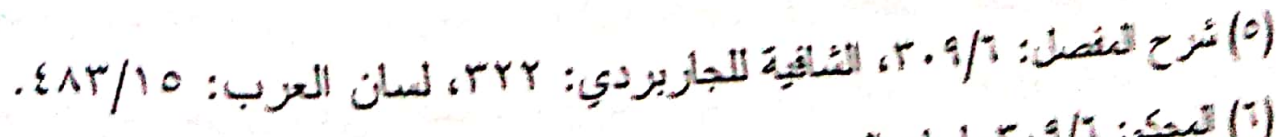

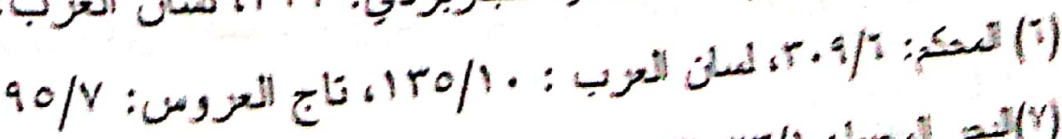

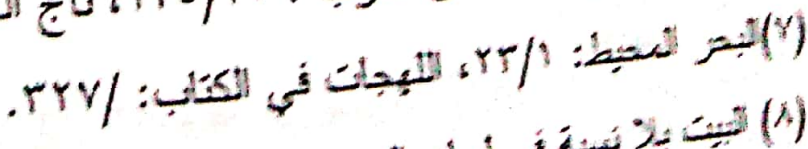

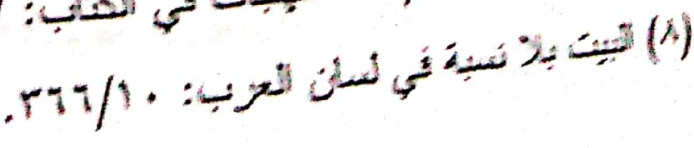




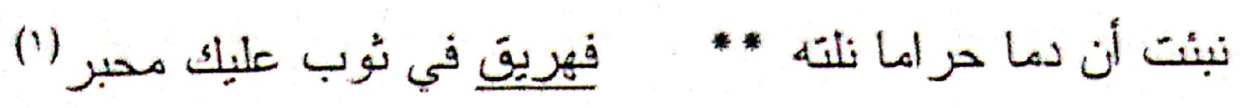

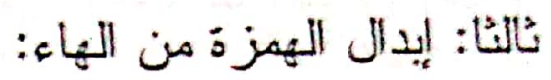

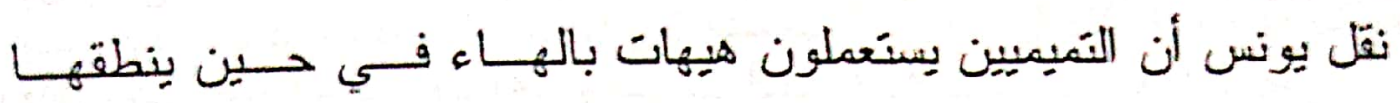

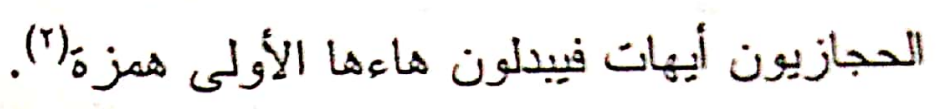

و إذا كان بنو تميم آثروا الهاء في هذا اللفظ على الهمزة التي اختار ها أهل الحجاز ، إلا أن الصيغة النميمية هي التي شاعت في اللغة النموذجية بدليل

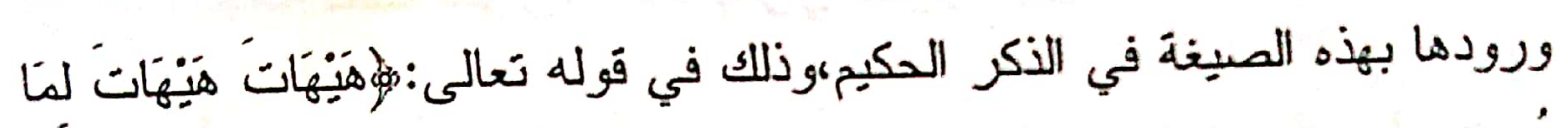

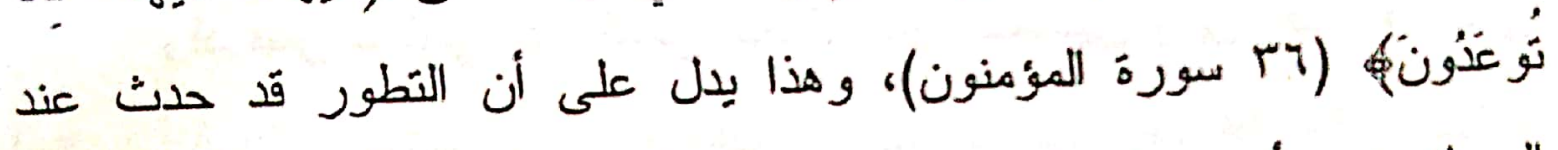
الحجازيبن، وأنه حدث بطريق التغاير، فبعد أن كان اللفظ بشتمل على حرفين من جنس واحد، هما الهاء أبدلوا الهاء الأولى همزة (r). رابعا: إيدال النون من الهمزة:

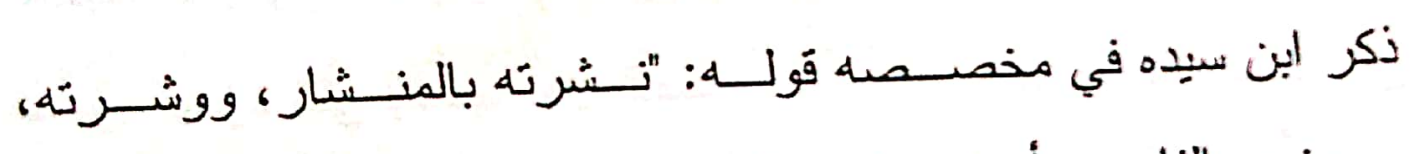

و أثنرته.... وزعم الفارني أن تميم تَهز المنشار وغيرهم لا يهمز "(؛).

$$
\begin{aligned}
& \text { (1) البيبَ بلا نسبة في المصدر السابق. }
\end{aligned}
$$

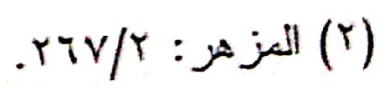

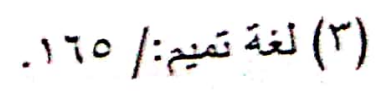

$$
\begin{aligned}
& .1 \wedge \mathrm{V} / \mathrm{IT}:
\end{aligned}
$$




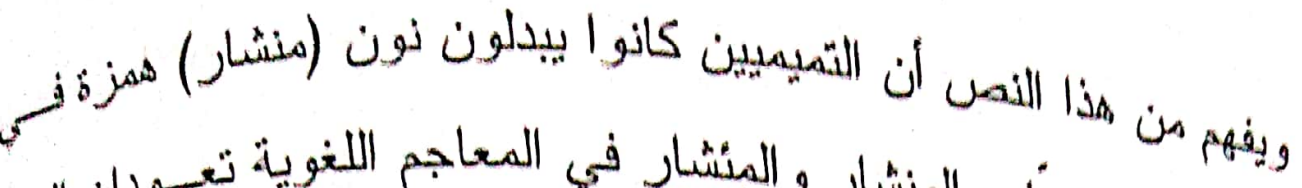

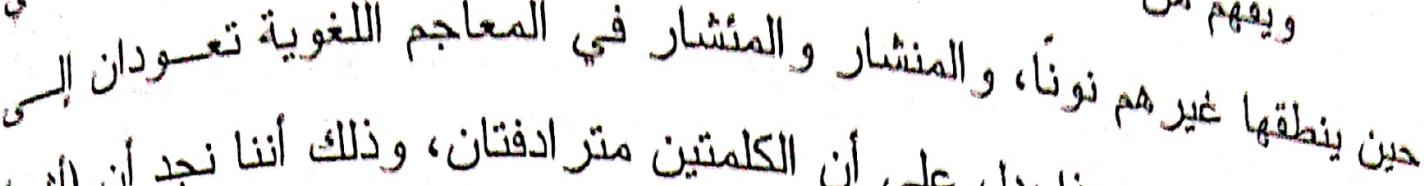

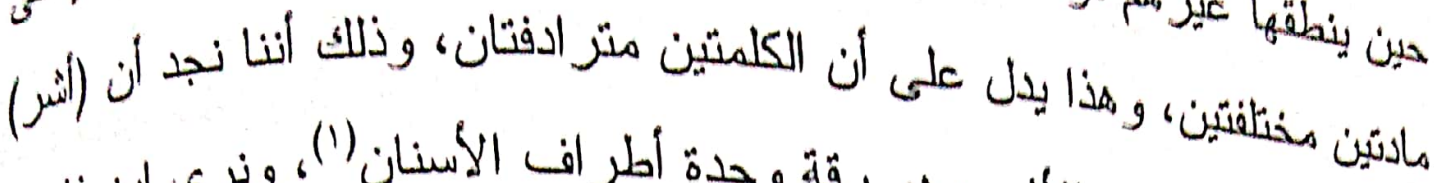

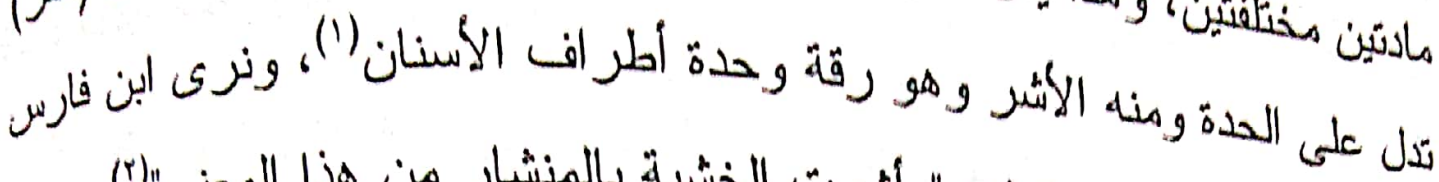
يعلق على هذا الهنفى بقوله: "و أشرت الختبة بالمنشار من هذا المعنى"(").

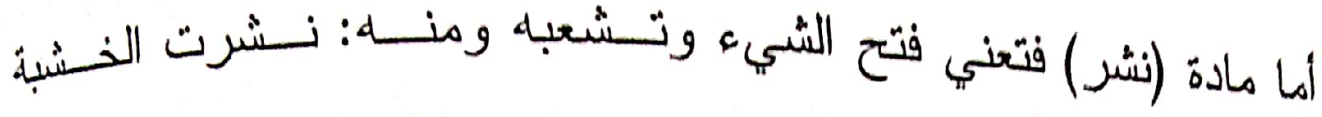
بالمنشار (r). ونلدظ أن الصلة بعيدة بين الهمزة و النون وقد تنبها إلى ذلك من فيل ابن سيده فجعله تحت عنوان: "ومما يجري مجرى البدل"("). وقد فسر ضاحي عبد الباقي الخلاف بين التميميين وبين غيــرهم فـي إبدال نون منشار همزة بقوله: " إن العربي اشتقق من نشر اسم آلة فقال: منشار، ثم طر أ على هذه اللفظة نطور فأصبحت (ميشار) بإيدال الياء من النون، والصلة

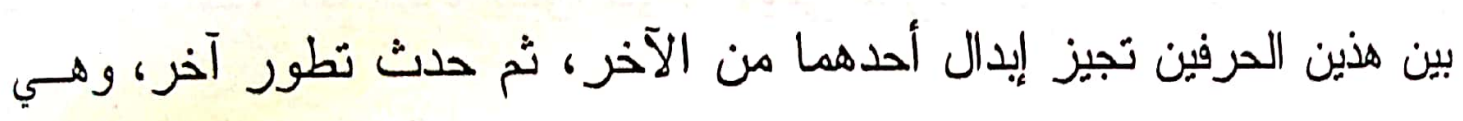
الصيغة المهوزة التميمية (مئشار) وتفسير ذلك أنه لما كان من دأب التميمبيسن

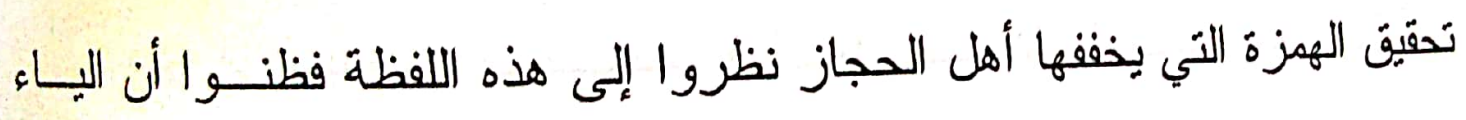
مبلة من الهمزة فحققو ها بقو لهم (مئشار) "(o).

$$
\begin{aligned}
& \text { (1) الهصدر السنابق. }
\end{aligned}
$$

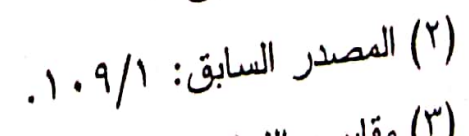

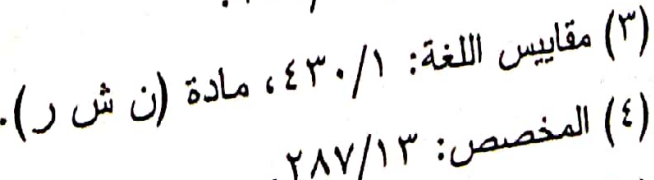

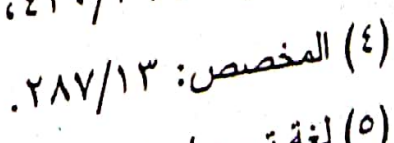

$$
\begin{aligned}
& \text { ) }
\end{aligned}
$$




\section{خامسا: إبدال الثواو المو اقعة فاء همزة:}

نقل جماءة من أهل اللغة منهم ابن بريد أن المينليين كانوا يبذلون التواو

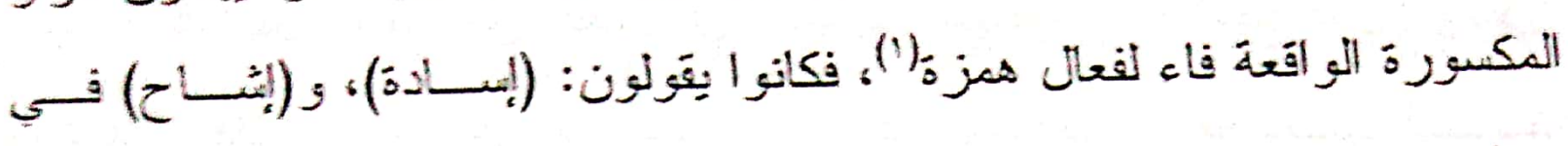

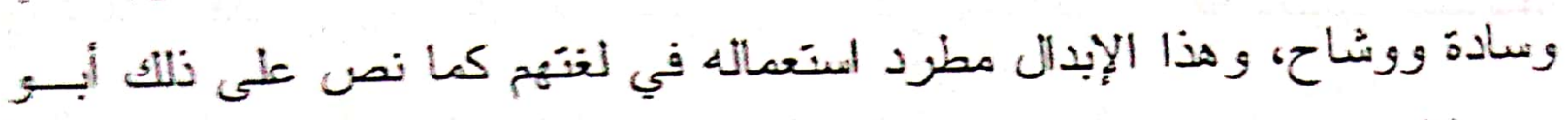

وقَّ ورد هذا الانستحمال في لغَتهم في منل قَل شاعز هم:

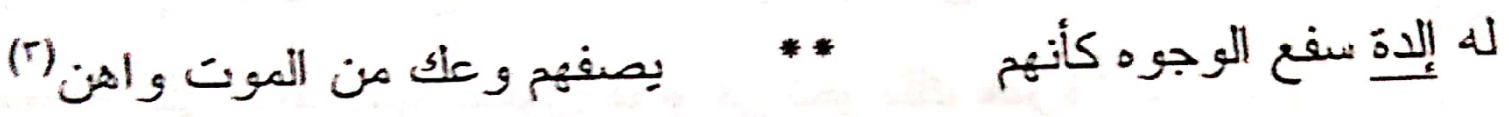

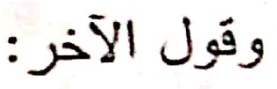

لإلدك أصدابي فلا تزدهيهُ * * بسابة إذا مدت عليك الحلائب(ء)

$$
\text { وقول الآخر: }
$$

هو اء منل بعلاك مسنميت على ما في إعائك كالخيال(م)

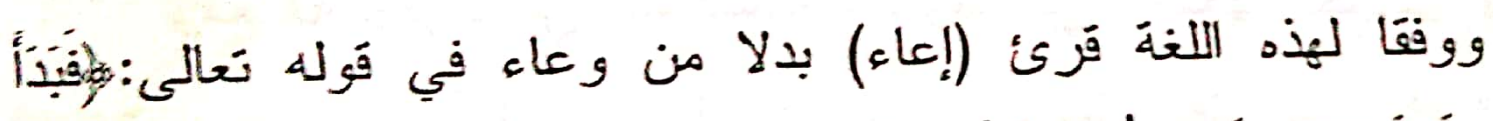

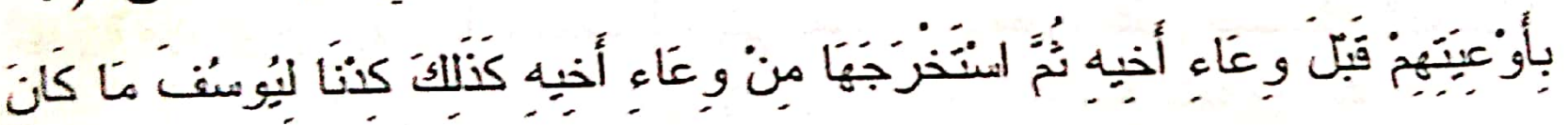

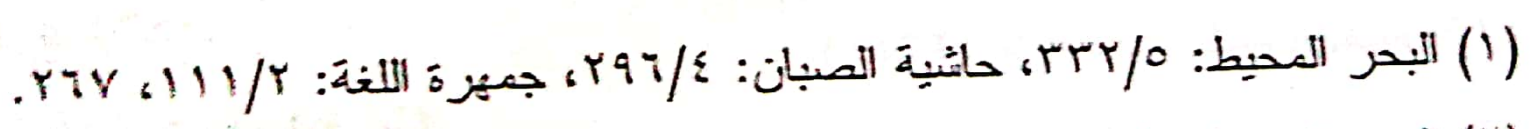

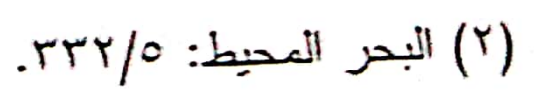

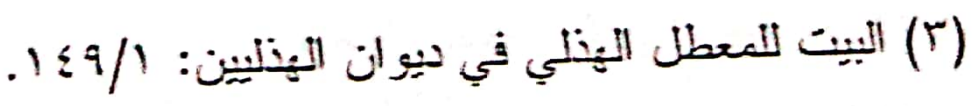

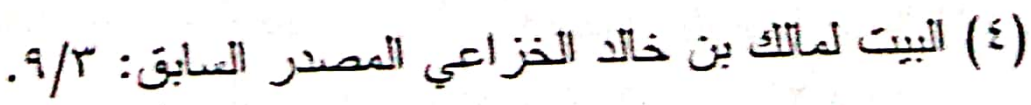

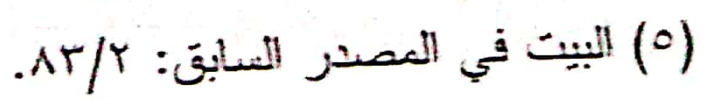




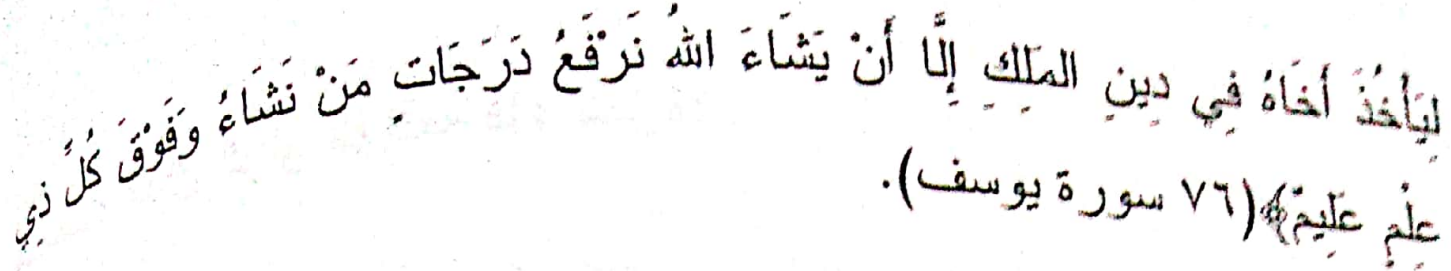

كما نقل القالي عن الخليل أن التميميين بنهجون هذا النهج فقال : ولثرل

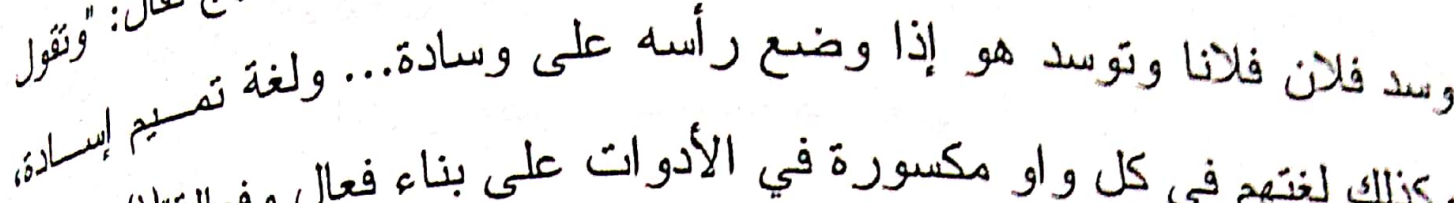
وكذلك لنتهم في كل و او مكسورة في الأدو ات على بناء فِعال وفِعلةَ"(') و أكد ابن منظور كلام الخليل ونقل عن ابن سيده: "أن الوقط والسوئط

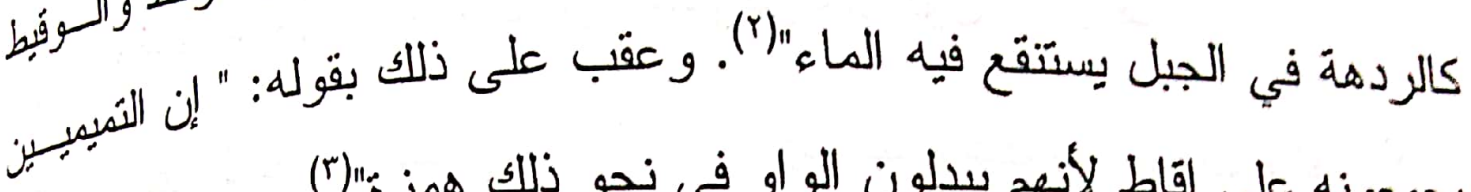
يجمعونه على إقاط لأنهم يبدلون الو او في نحو ذلك همزة"("). ومع هذا نجد أن بني تميم قد خالفو ا نهجهم السابق فأبقو اعلى الهزةةفي لفظ (الإكاف) (؛)، بينما استعماها أهل الحجاز بإبدال الههـزة واوا (الوكساف)،

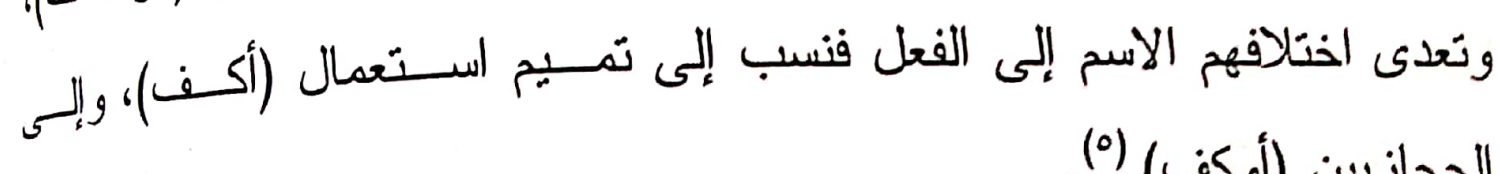
الحجازيين (أوكف) (०)

ومع أنه توفرت في هذه اللفظة الشروط التي وضعها الخليـل لإبـال

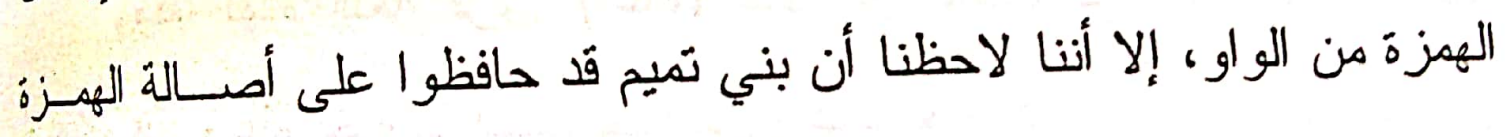

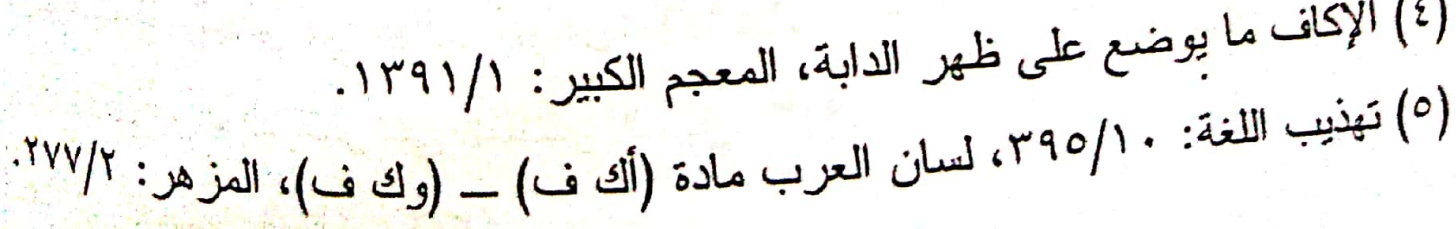


فيها. وقَ شاعت الصنية التميمية (إكاف) واستعملثها اللغة النموذجية، فقد روي

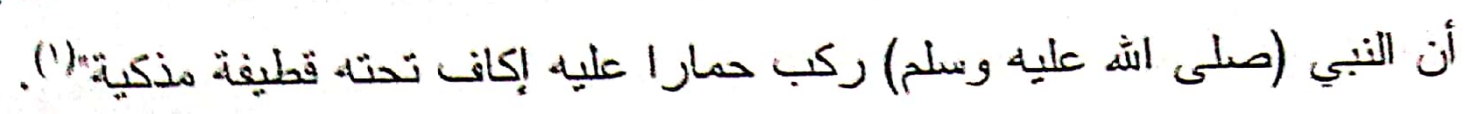
كما وردت بهذه الصنيغة في قَول الراجز التميمي:

\section{كالكرون المشدود بالإكان (r)}

وكما آثرت هنيل إيدال الواو المكسورة الواقعة فاء للكلمة هزة، أبدلت

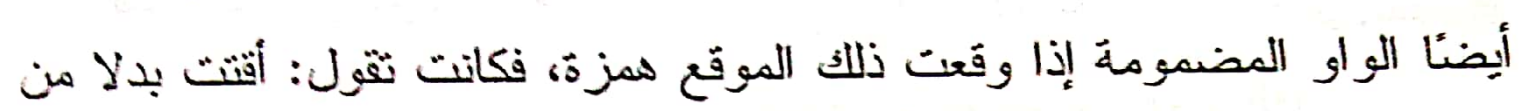

gr)

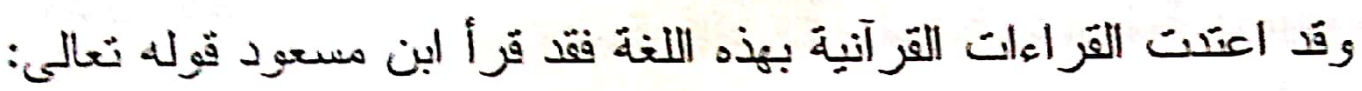

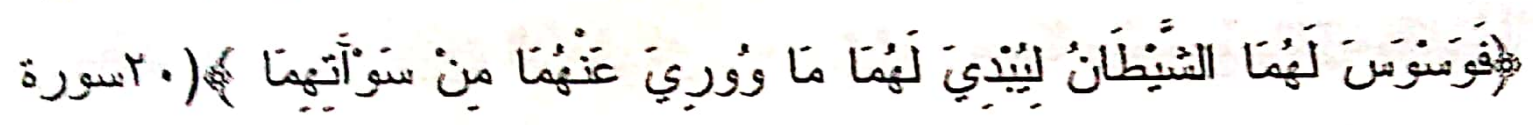

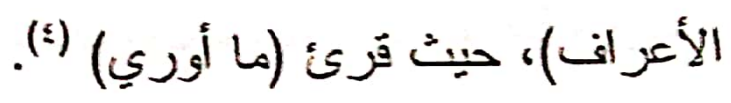

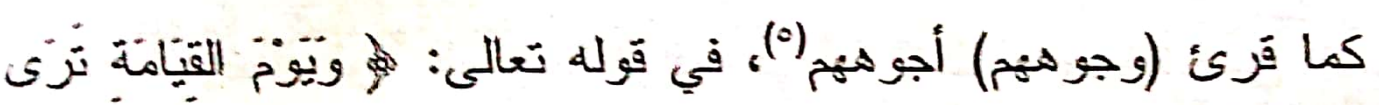

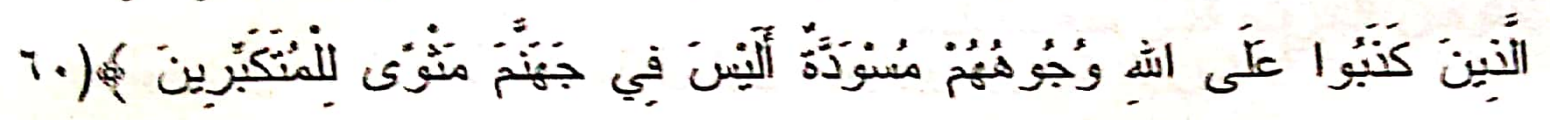
سنورة الزئمر

كما وردت هذه اللغة في ترانهم الشعري، وذلاك نحو قول الشاعر:

$$
\begin{aligned}
& \text { (1) صحيح مشلم حديبد رةم (YY (1) ). } \\
& \text { (Y) التزجز في لهان اللعرب. مادة (وك ن). }
\end{aligned}
$$

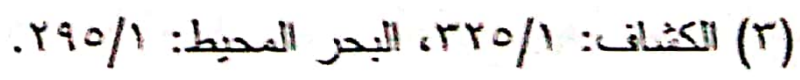

$$
\begin{aligned}
& \text { (5) البحر المحيط: 10\% } \\
& \text { (0) المصنر العابي: (1) }
\end{aligned}
$$


أبا معقل فانظر بنبلك من ترمي)(1)

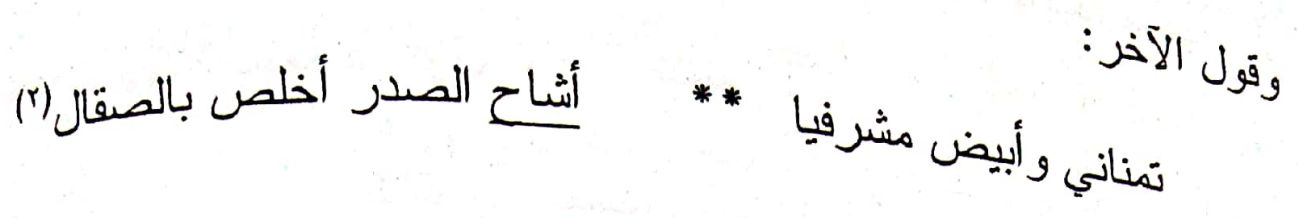
أبا معقل إن كنت أشهت وقد عقب ابن جني على هذا البيت بقوله: "يريد ودي و هي لغته."(؛)

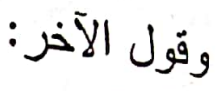

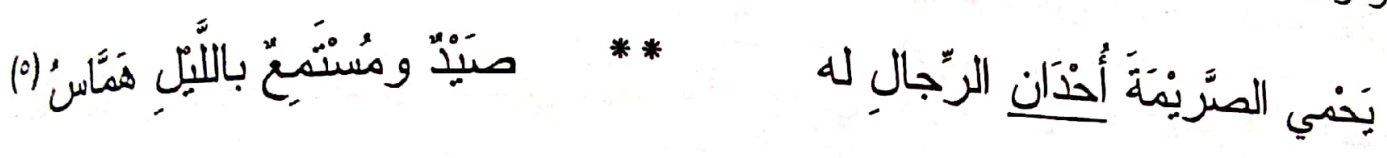

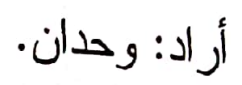

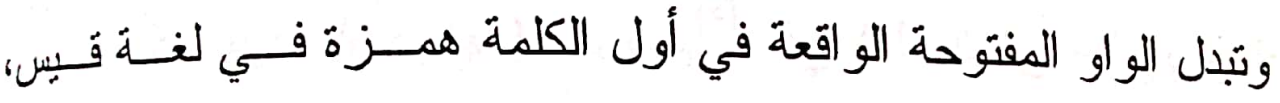
فيقولون: أرخته تاريخا، في مقابل قول التميميين ورخت توريخا.(")

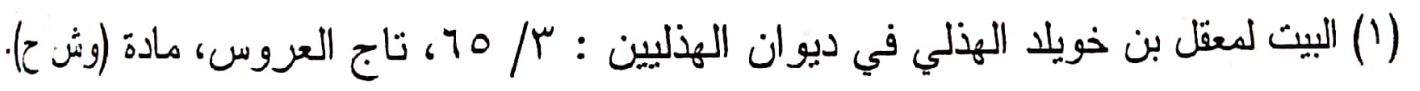

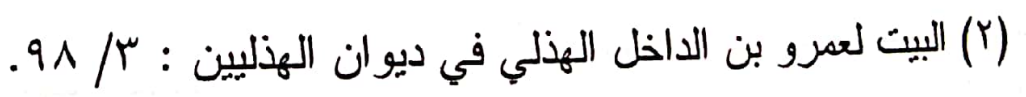

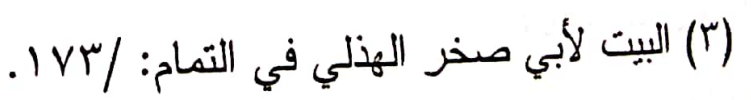

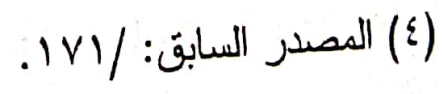

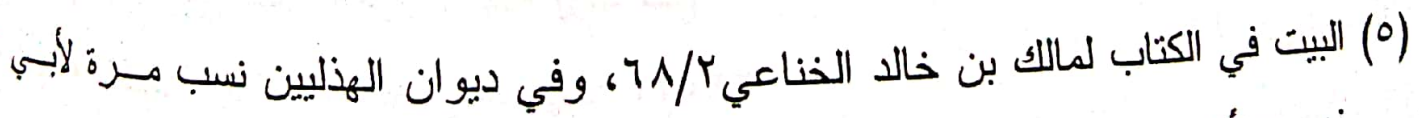

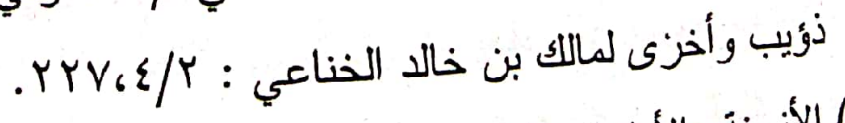

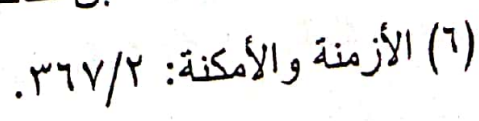

$$
0.1
$$




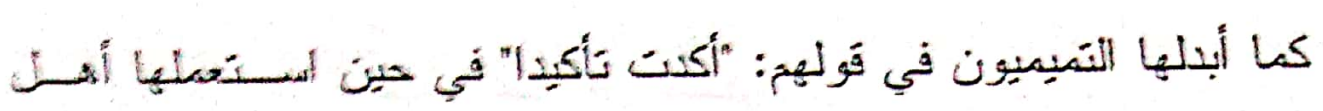

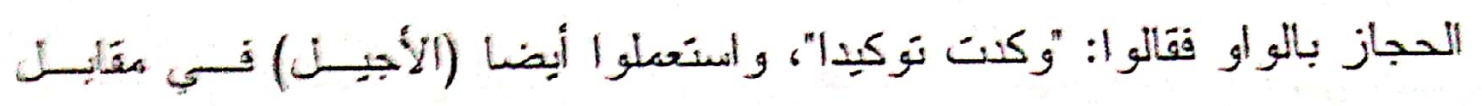
أسنعمال الحجازيين (الوجيل) (")

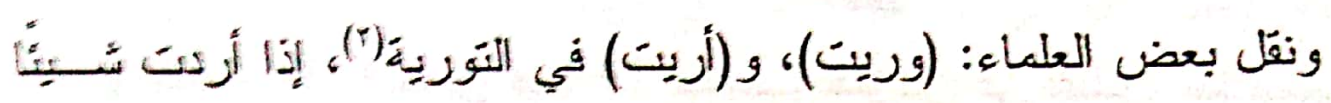

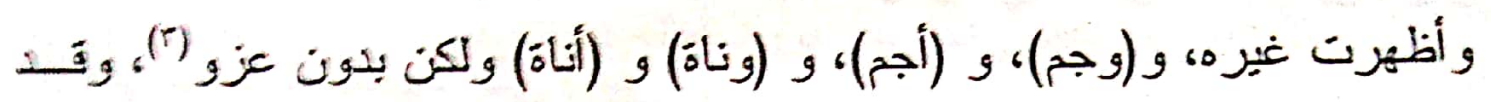

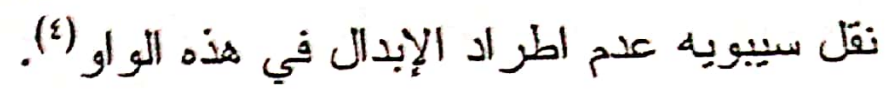

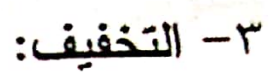

حدد سييوِيه المقصود بالتخفيف أنه نطق الههزة بين بين (م)، وذلك بأن يكون

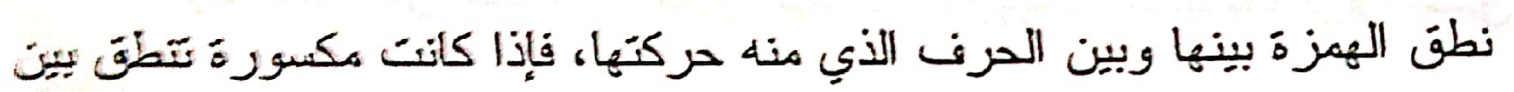

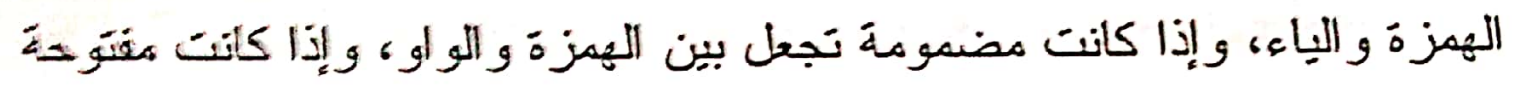

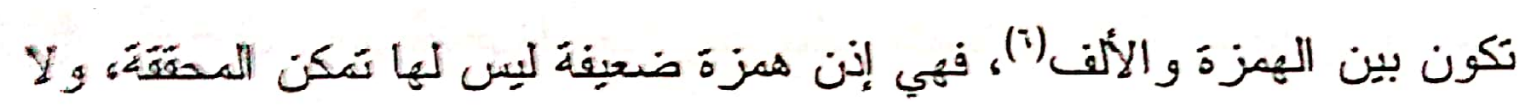
خلوص الحرف الذي منه حركتها(").

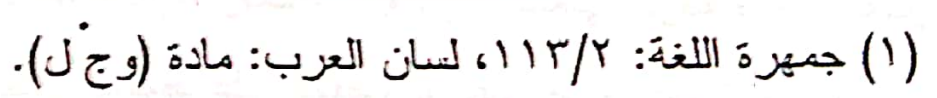
(Y) (ب) لسان العرب :مادة (وري).

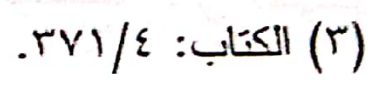
( ) ( المصدر النبابق.

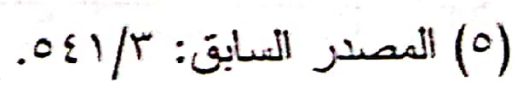

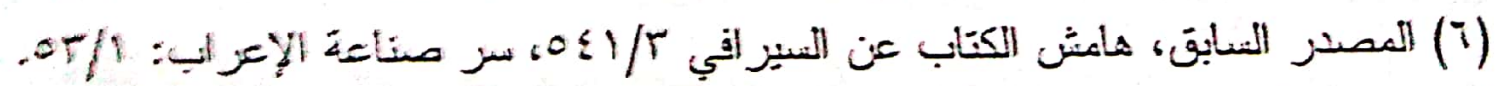
سز (V) 


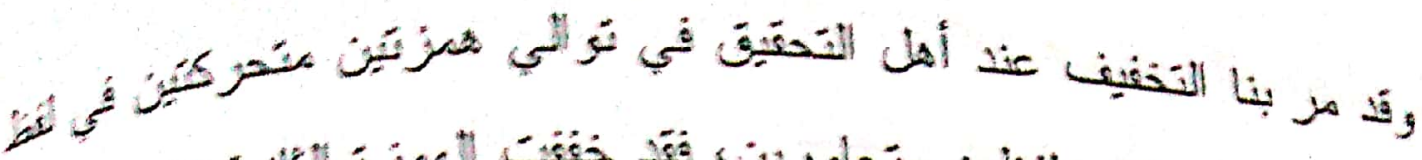

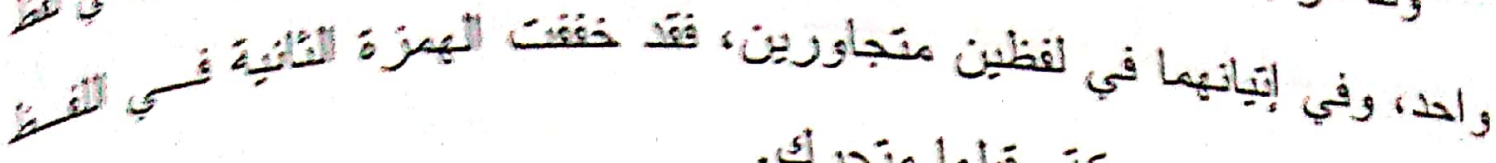

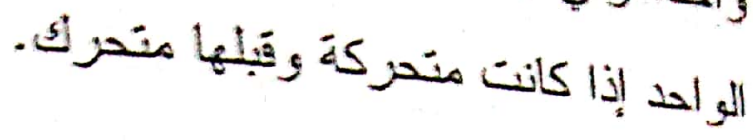

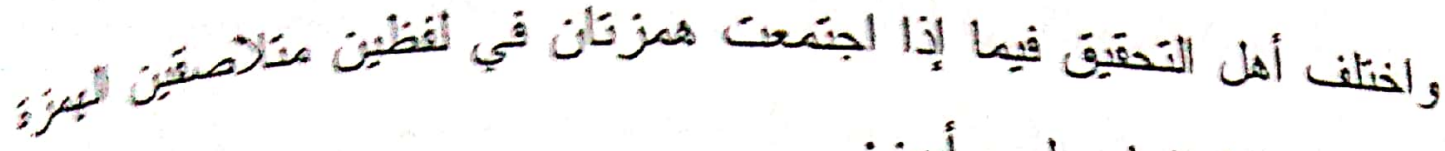

$$
\text { الأولى ليست للاصنفهاج على رأيبين: }
$$

- الأول: تخفيف الأولى وتحقيق لالثانيةَ.

- الأني: تحقيقَ الأولى وتخفيف الثانتية:

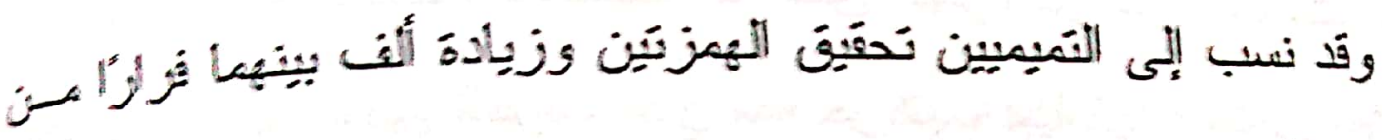

اجنماع منماتلتين.

\section{؛ - التحقيق (نبر الاهمزة)(')}

عمد العكليون وبنو تمِيم إلى همز الألف إذا جاء بعنها حرن مسضقة

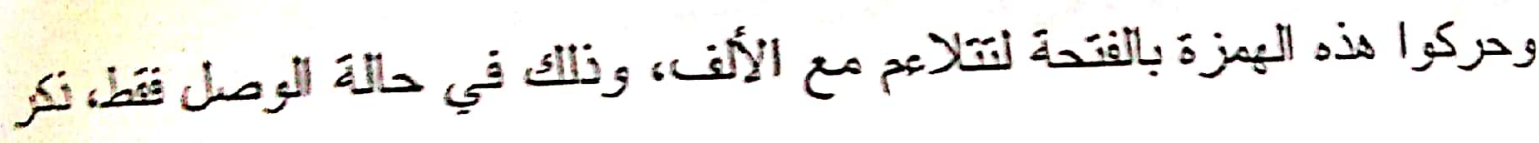

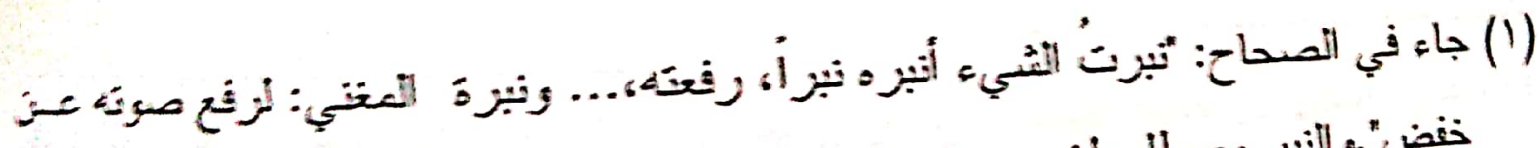

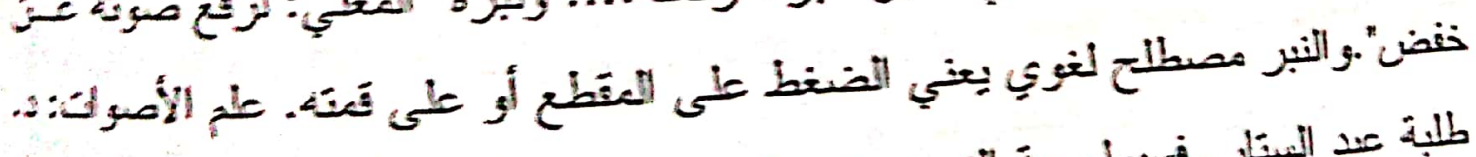

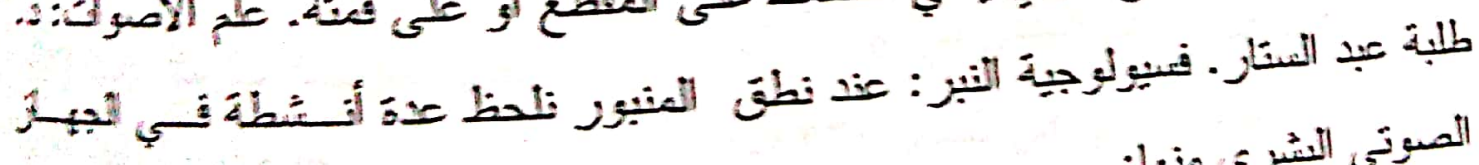
الصوني البشزبي منبا:

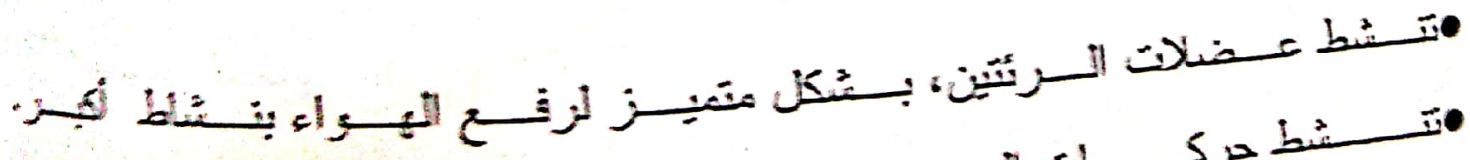

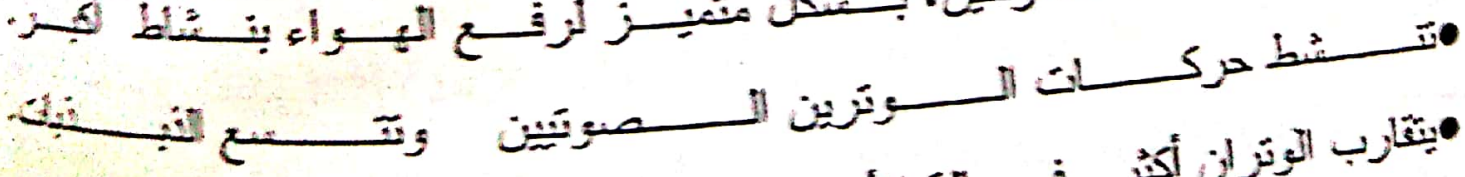

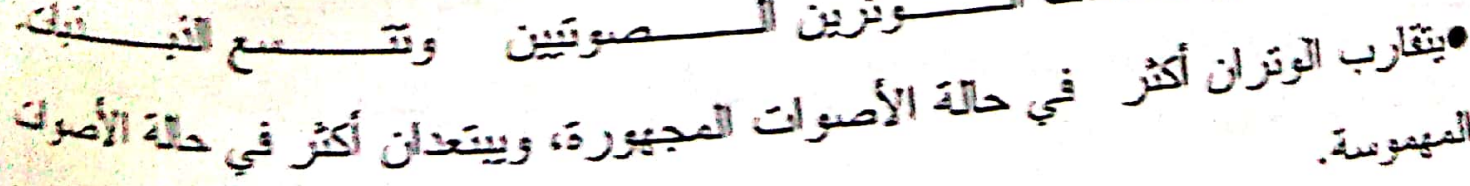


ذلك الشنقِطي حيث قال: "ربما فُرَ" من التقاء الساكنين في المنصل بإبدال همزة

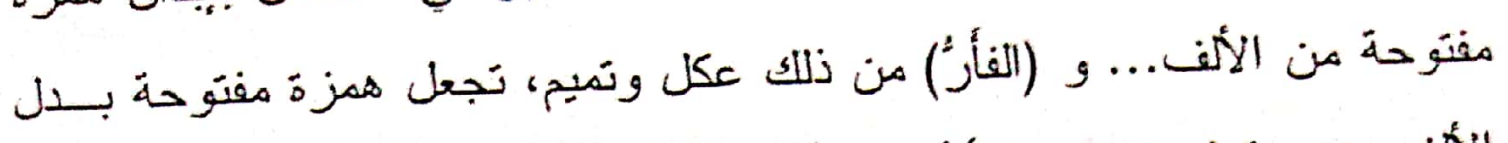

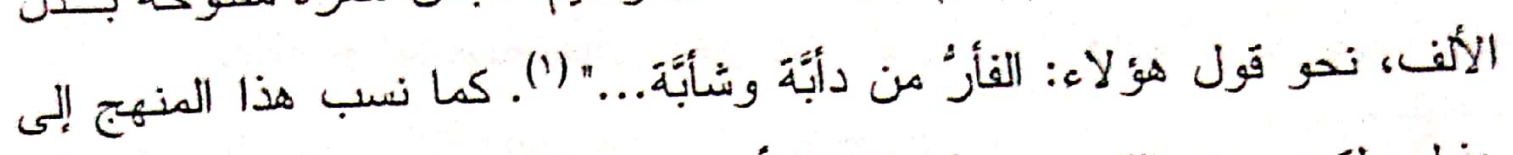
هذيل ولكن بعض اللغوبين عدً هذا شَذوذا في لغنهم (r).

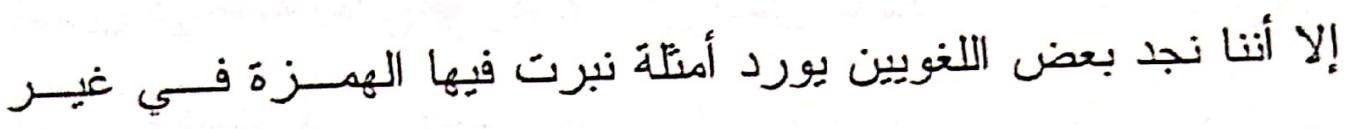
الموضع الذي حدده النص السابق، فذكر أن العقيليين كانوا بِهزون (الجؤنة) و (المؤسي) و (الحؤت)، و الثشائع استحمالها بدون همز (r).

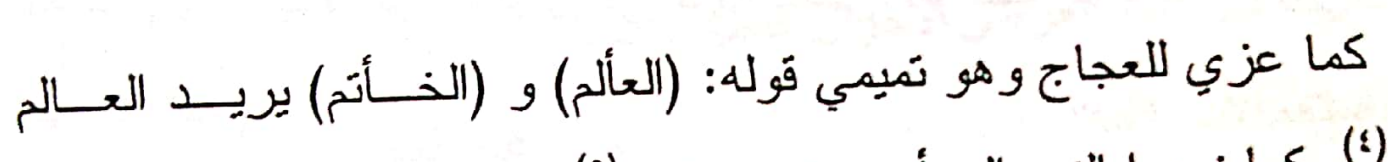
والخاتم (؛). كما نسبوا النبر إلى أسد و غني وقِيس(0).

كما ورد النبر في القراءات القرآنية الشاذة حيث قرئ (و الضألين) من

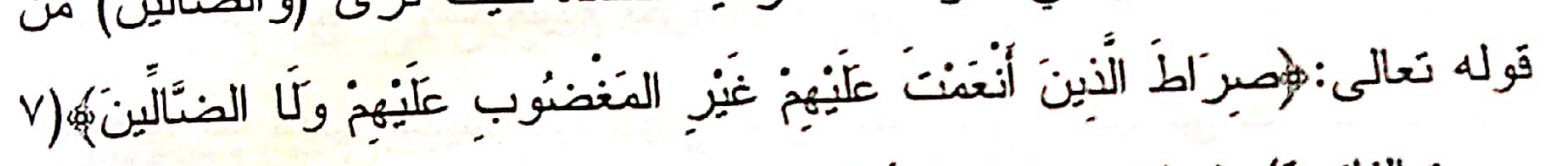

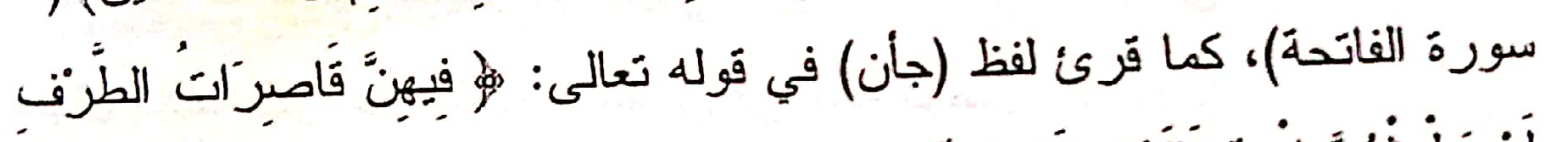

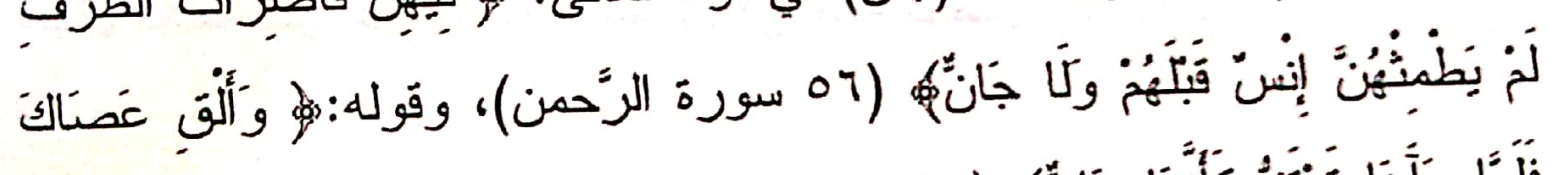

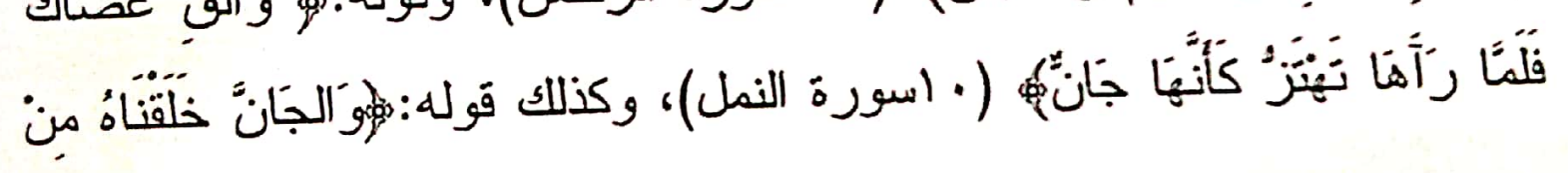

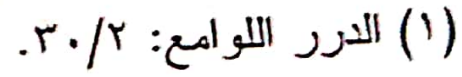

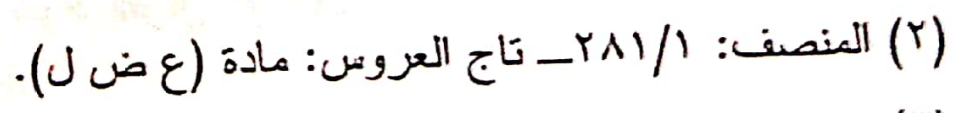

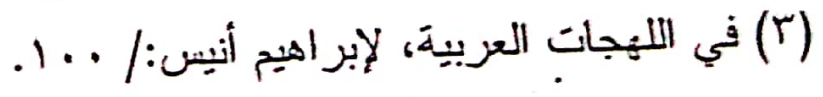

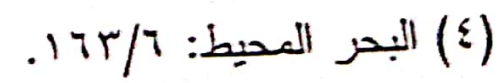

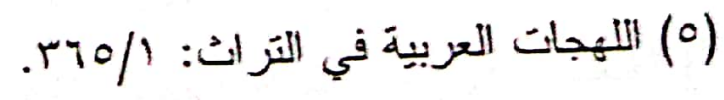




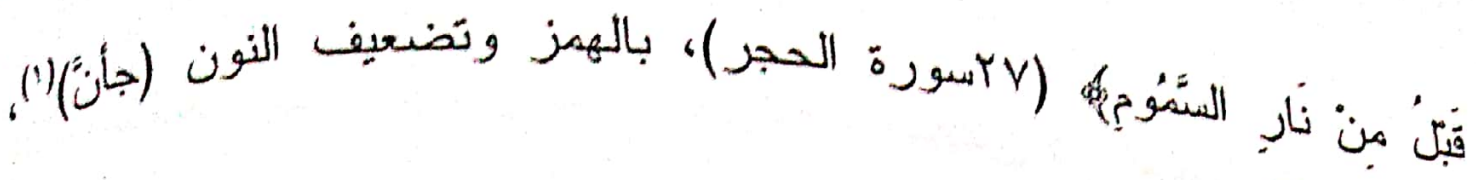

و (الجأن) (")

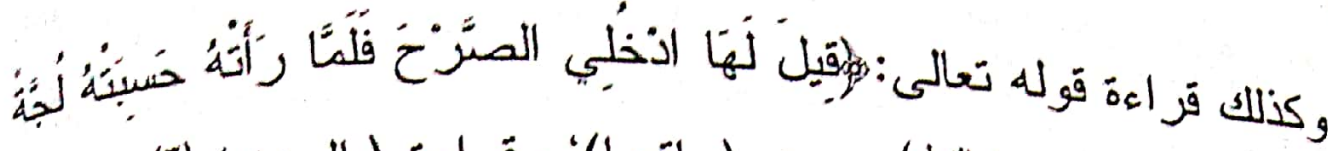

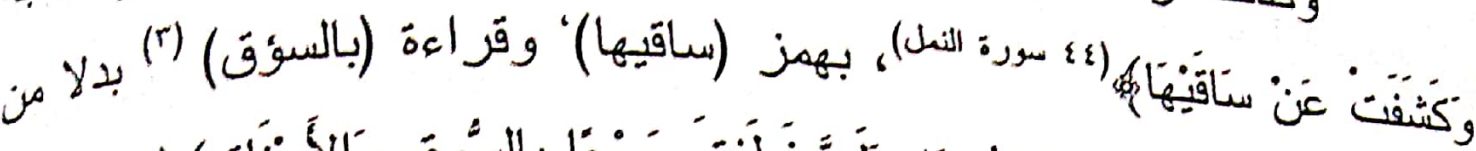

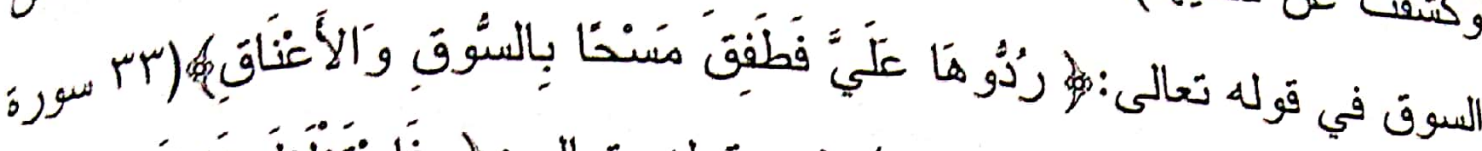

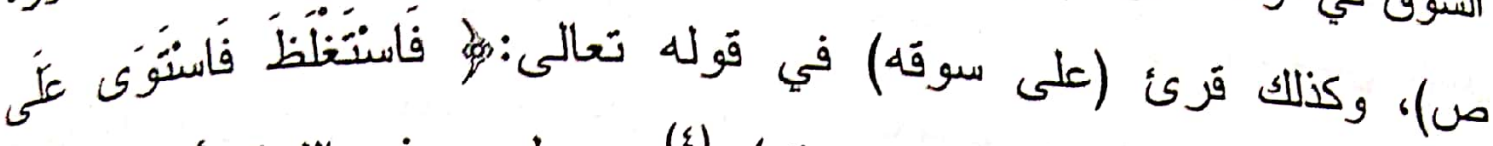

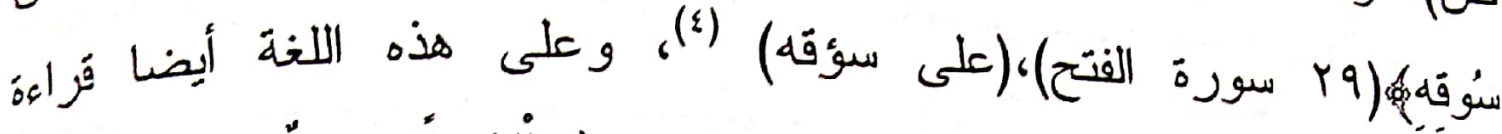

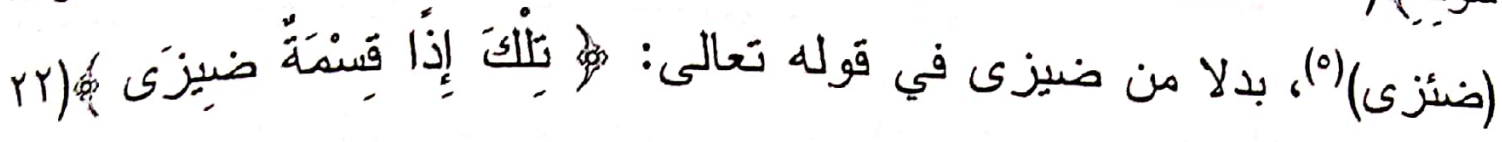
سورة النَّمج). من هذا يتضح أن النبر لم يكن مقصورًا على ألف المـــ وحسدها، ولا

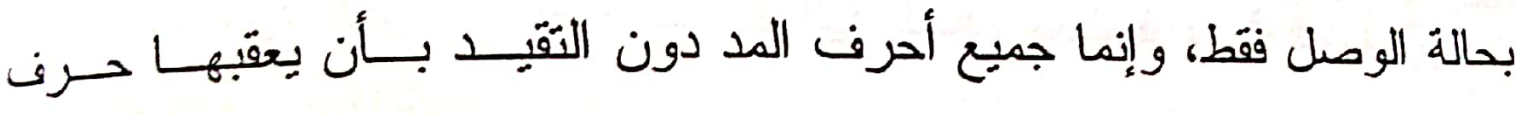
مضعف، أما سبب اقتصار الشنقيطي على الحالة التي عيّنها في كلادسه فـلأن

مجال كلامه كان على الثقاء الساكتين في حالة الوصل (").

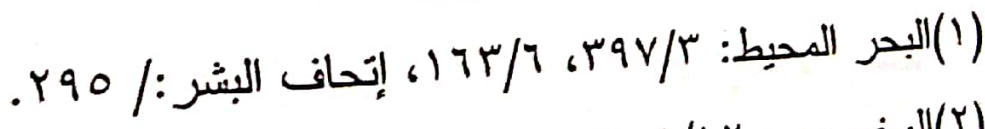

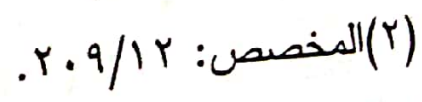

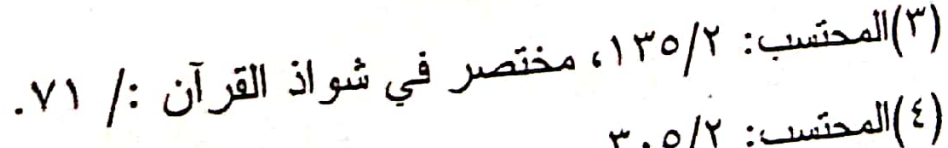
r.

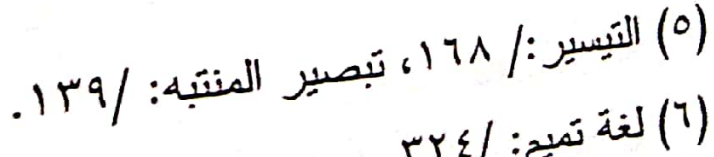
(T) 
ويقصد بها زيادة ألف بين الهززتين المتجاورتين سواء أحققت إحسـداهما

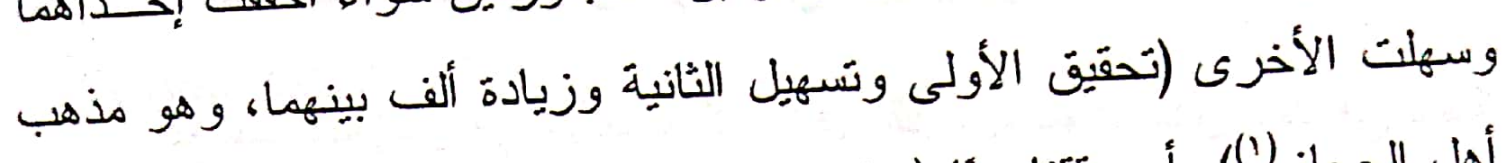

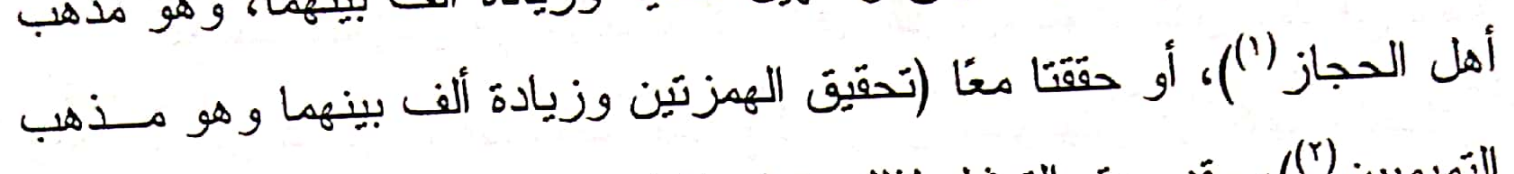

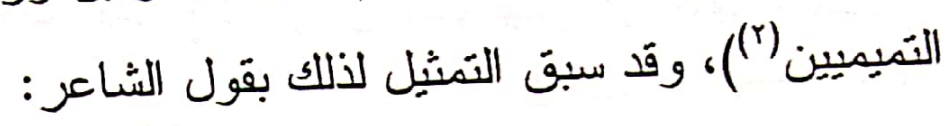

وبين النقا: آنَتِ أَمُ أُمُ سالم.

فِيا ظبية الو عساء بين جلاجل

من خلا هذا العرض لأحوال النطق بالهمزينين المتجاورتين في قراءات

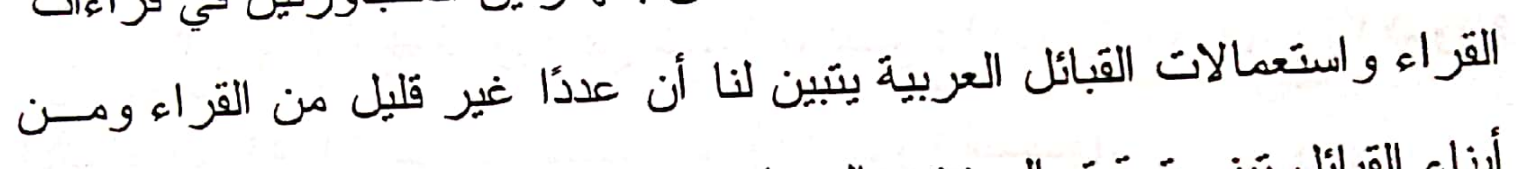

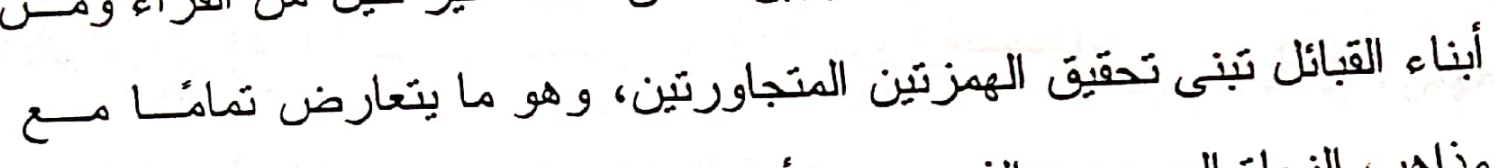

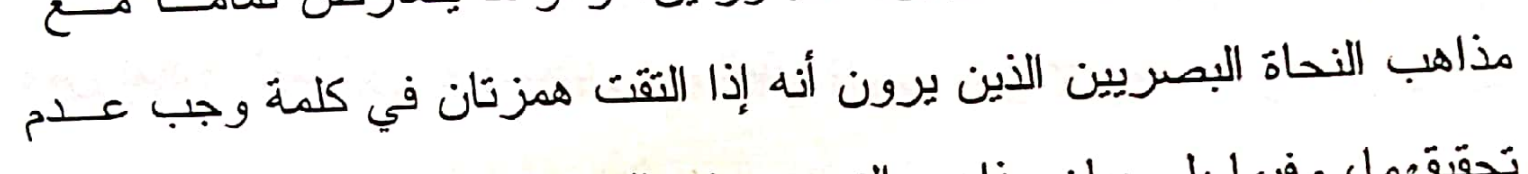

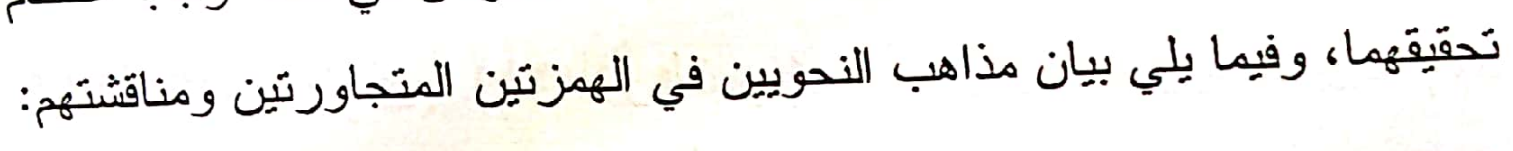

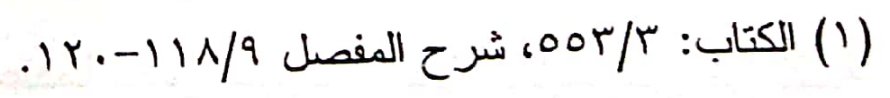

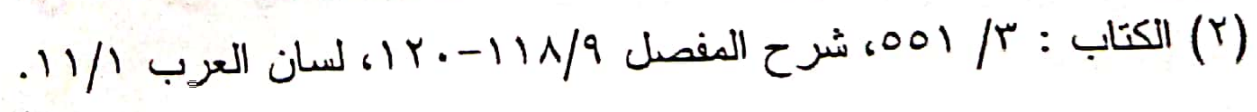

$$
0 . V
$$




\section{الوقفة الثانية}

\section{مذاهب النحويين والقزاء في الهمزتين المتجاورتين}

تو الت الهززتان في مواضع كثيرة في القرآن، سواء أكان ذلك في كلمة واحدة أو في كلمتين، و هذه بعض نماذج للهمزتين المتو اليتين في كلمة واحدة:

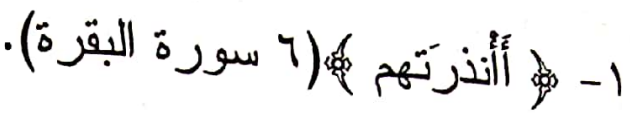

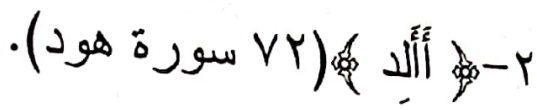

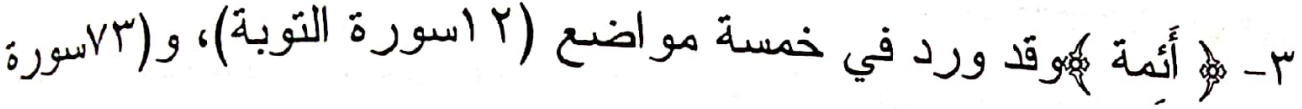
الأنبياء)، و (0، اع سورة القصص، و (ع سورة السجدة). ومن نماذج الهمزتين المجتمعتين في كلمتين:

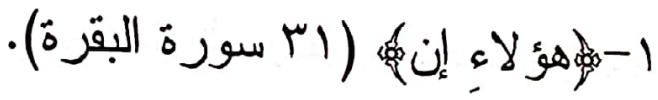

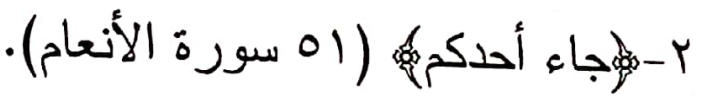

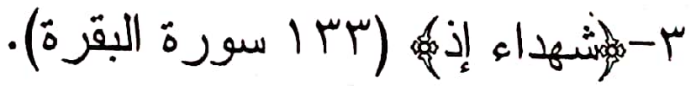

وقد نتج عن تجاور الهمزتين خلاف كبير بين النحويين والقزاء، حبـث حقق الهزينين في هذه المواضع كل من عاصم و ابن عامر وحمزة و الكسائي وخلف وروح. وقد رد كثير من النحاة هذه القز اءة، و عدوها من وهم القزاء. وترجع أصول هذه المشكلة إلى سيبويه الذي قرر في أكثر من موضع في الكتاب أنه ليس من كلام العرب أن تلتقي همزتان فتحققا سواء أكانتا في كلمة واحدة أو في كلمنين. وذلك عندما ناقش سيبويه النطق بالهمزتين في كلمة

$$
0.1
$$


واحذة، فإنه لم يذكر تحقيق الهمزنين كلنيهما على الإطلاق، حيث فال: "واعلم

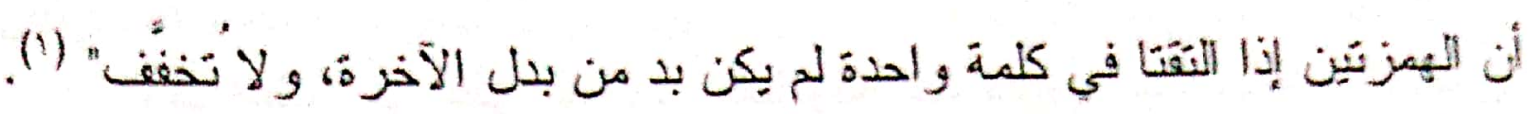
أما إذا التقت الهمزتان في كلمتين فإنه يرى أن أهل التحقيق بخفهـون

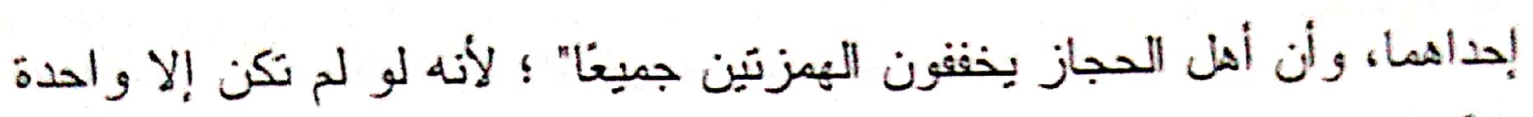

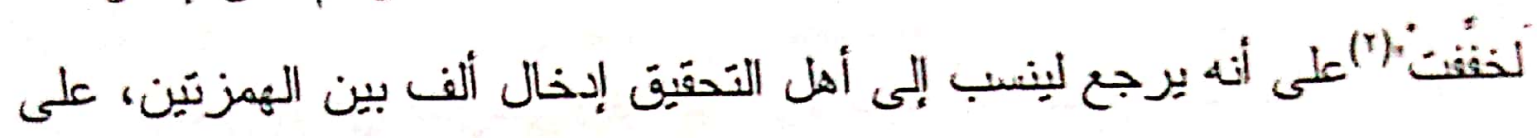
نحو ما جاء في بيت ذني الرمة:

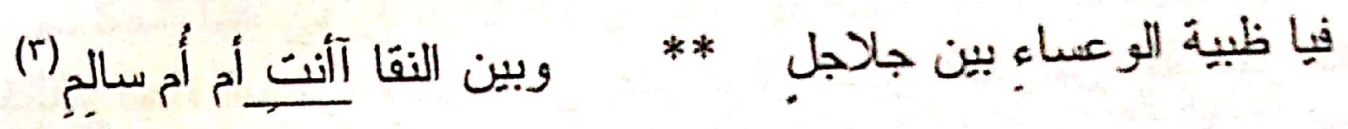
وعلى الرغم من أن سينيويه كان واضخًا في تبني هـــه الآراء حــول

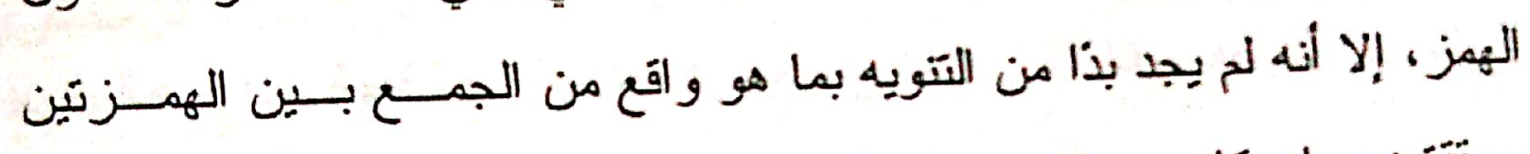

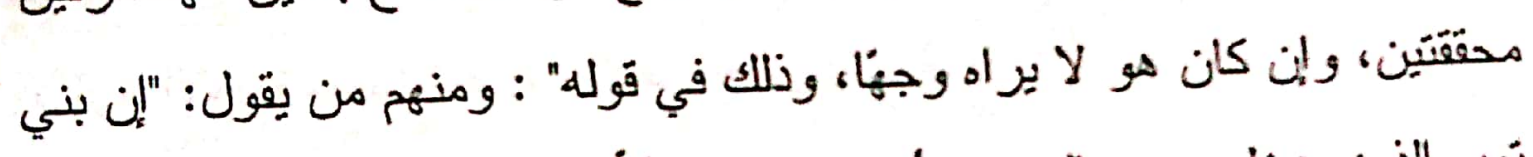

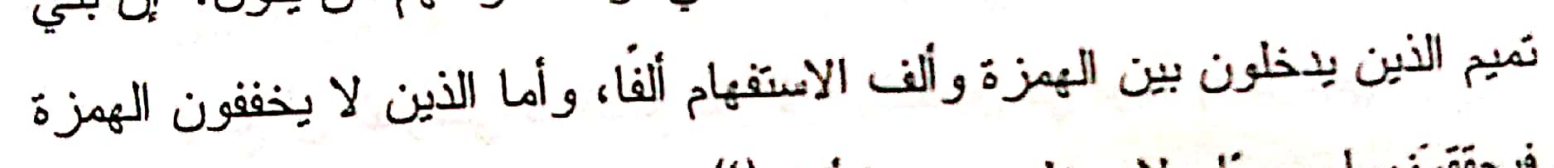

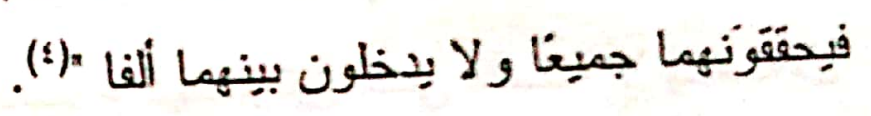

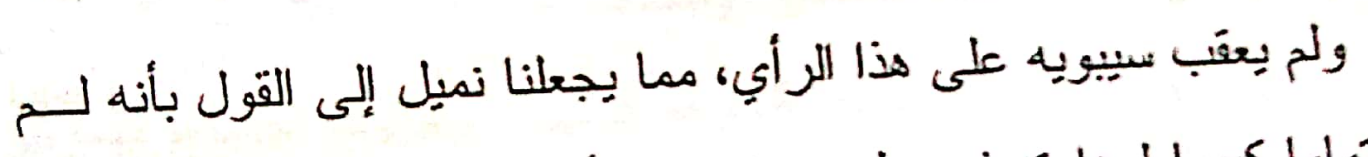

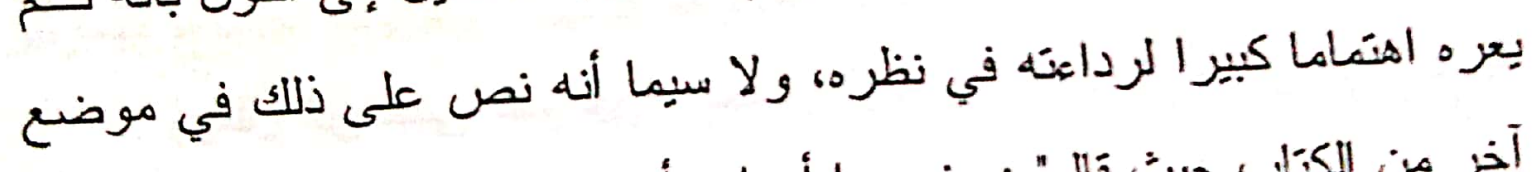

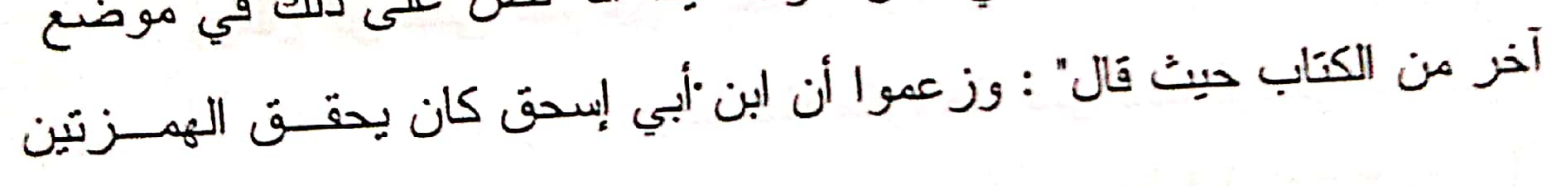

$$
\begin{aligned}
& \text { (1) } \\
& \text { (Y) } \\
& \text { (r) البي.ت سبق الاستكلال به. (r) } \\
& \text { (؛) الكتاب: }
\end{aligned}
$$


وأناس هعه، وقد تكلم ببعضيه العرب، و هو رديء" ('). وقد اعتذر أبو علي الفارسي عما وقع عند سيويه مما ظاهره الثناقضن

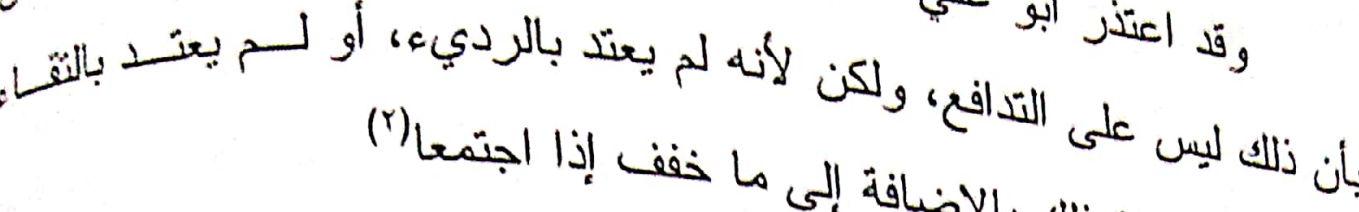

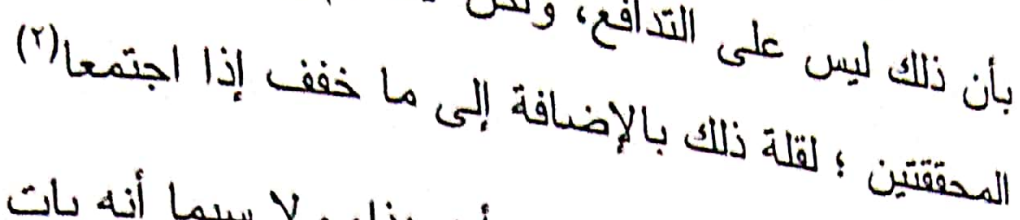

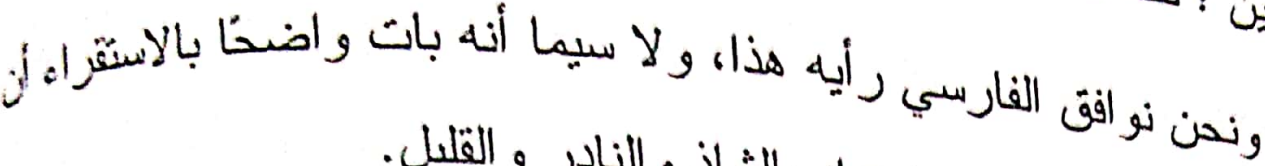
من منهج البمسيين عدم الاعتداد بالشاذ و النادر و القليل. ثم خالف نحاة البهرة سيبويه في عدم جواز تحقيق الهمزتين؛ فقد ذكر اللبرن. أن هذا قول جميع النحويين إلا عبد الله بن أبي إسحق الحضرمي ؛ فإنه كـلـال يرى الجمع بين الهمزتين (")، وقال في موضع آخر :" لا يلتثي همزتئن في كلة إنة

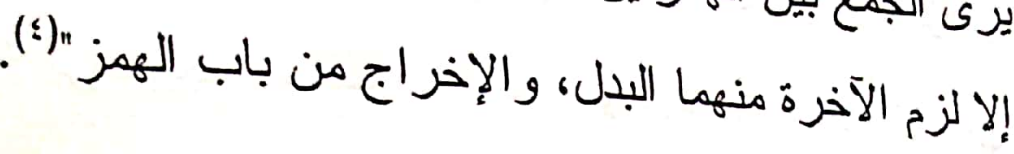
ومع أن الفارسي قد احتج لمن قر أ بالتحقيق في قوله (أنذرتَّه)، إلأند.

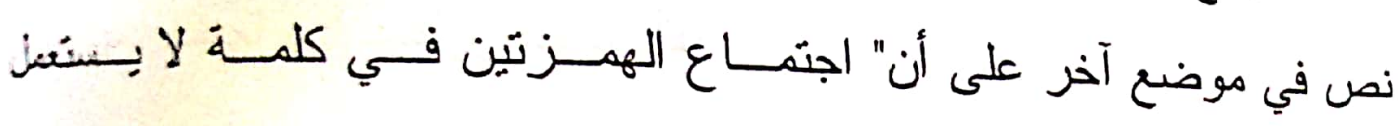
تحقيقهما"(ن)

ويعلل ابن جني عدم جواز تحقيق الهمزنين إذا كانتا أصلين في كلـة واحدة بانه إذا كانت الهمزة المفردة ثقيلة مكروهة، فمن باب أولــى البــكراه 
الثنتين ورفضهما، ولا سيما إذا كانتا مصطحبتين غير مفترقتين (')، ونحو"ا من

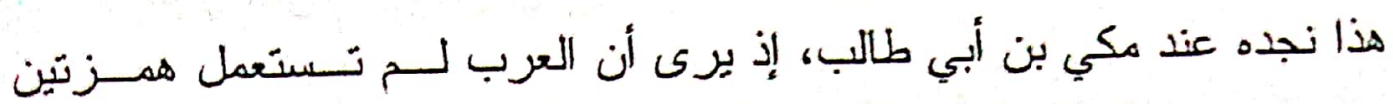
محقَقتين من أصل كلمةً (r).

أما الزمخشُري فلم بيكن منسجما في المسألة، فبينما نجده يرى جهـواز تحقبـتق

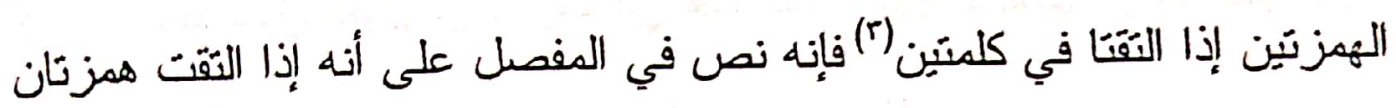

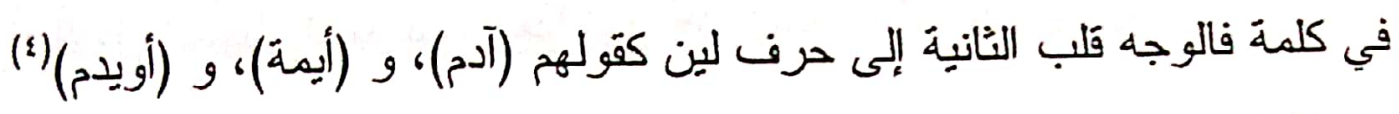
وو اضح من خلا أمتئة الزمخشري أنه لا يفرق في هذا الحكــم بــين الهمزة الثانية المتحركة والساكنة، ويفسره كلام الشارح إذ عد المتحرك في هذا لِيس بأقوى من الساكن(0)، على أن شارح المفصل علق على عبارة الزمخشري التي تفيد جواز تحقيق الهمزتين إذا التَتَا في كلمتين بقوله" : ليس فــي كـلام

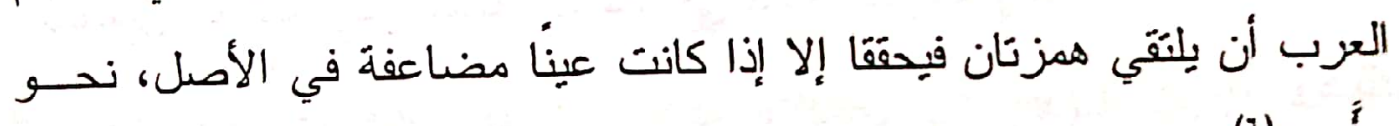

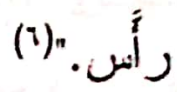

و أكثر من هذا ما نقله صاحب الإنصاف من كلمات البـصريين فـي

احتجاجهم لكون همةة بين بين منحركة، وهو قولهم : ولم يأت اجنماع الهمزتين في شيء من كلامهم إلا في بيت واحد، أنشده قطرب:

$$
\begin{aligned}
& \text { (1) سر صناعة الإعراب: (1// (1) }
\end{aligned}
$$

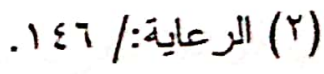

$$
\begin{aligned}
& \text { شر) } \\
& \text { (؛) المفصل: / }
\end{aligned}
$$

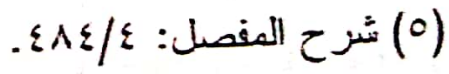

$$
\begin{aligned}
& \text { (آ) المصدر النسابق. }
\end{aligned}
$$




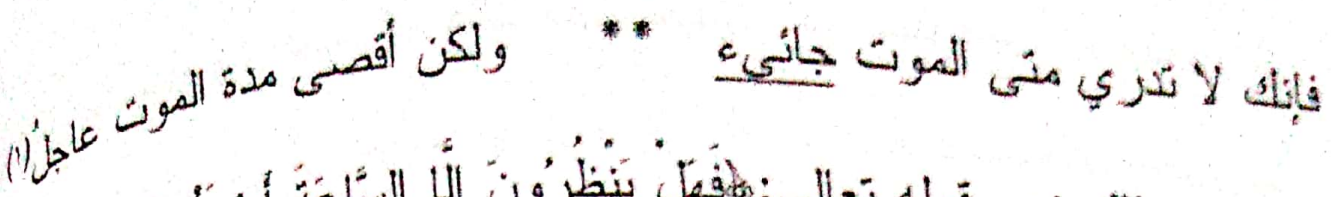

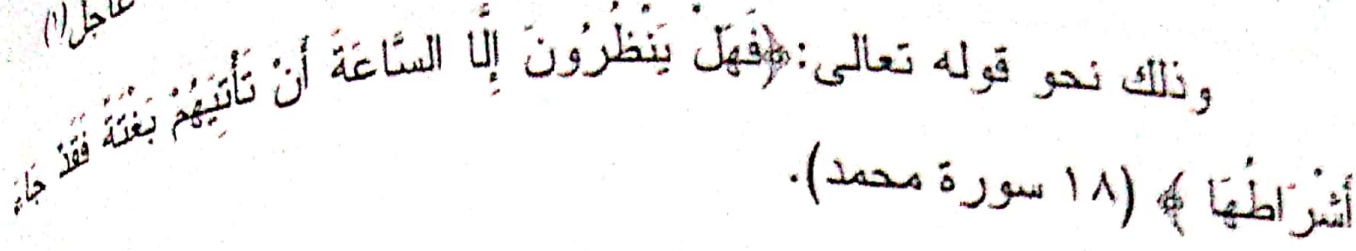
وقة سبق القول إن للعرب في هذه الحالة عدة مذاهب: - الأول: تسهيل الهمزتين: وهذا نهج أهل الحجاز (r). - الثناني: تحقيق الأولى وتسهيل الثَانية: ولم أقف على أصحابه. - النالث: عكس الثاني: أي تخفيف الأولى وتحقِيق الثانيةُ"(ا). - الر ابع: تحقيقهما: وقد نسبه الرماني إلى كثير من بني تمبحم(أ.

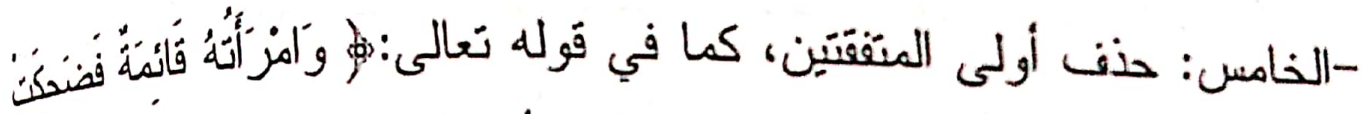

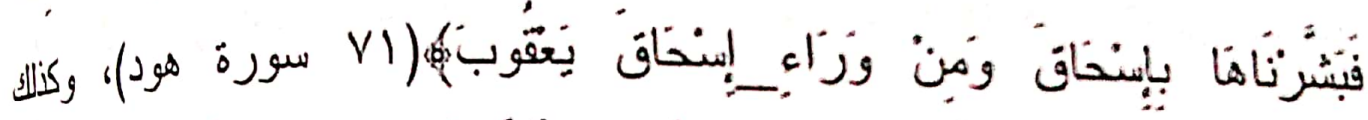

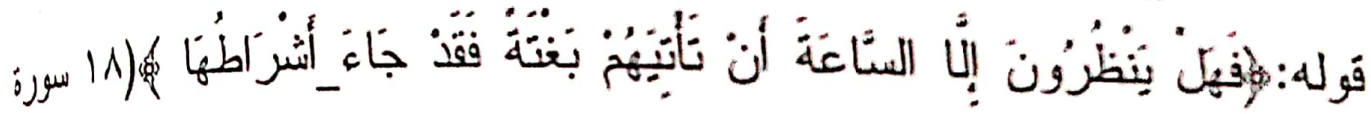
محمد). - السادس: إبدال أولى المنفقتين حرف مد صريح (*). ولم أقف على نسبة هـا الاتجاه فيما بين يدي من مصادر .

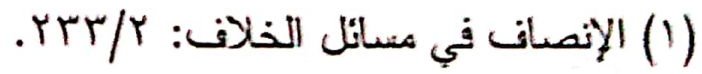

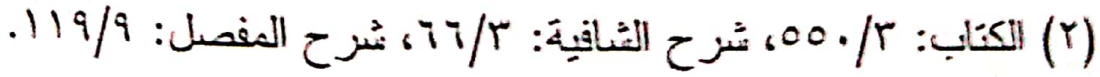

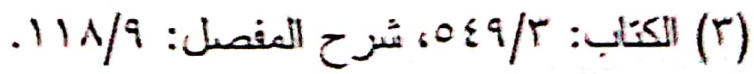

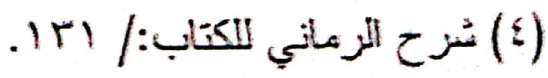

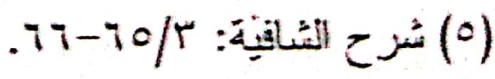


وقد قر أ القر اه بكل تلك المذاهب التي نسبث إلى المحققين("). ويمكن القول إن مذاهب النحويين والقراه في الهمزتين المتجاورتين قد جاءت في اتجاهين اثنين: - الاتجاه الأول: تخفيف الههز:

اتجه عدد من القر اه إلى تخفيف الههزة حبيث كانوا ليميلون إلى الفـــرار

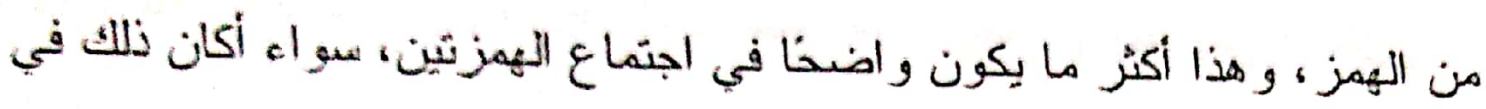

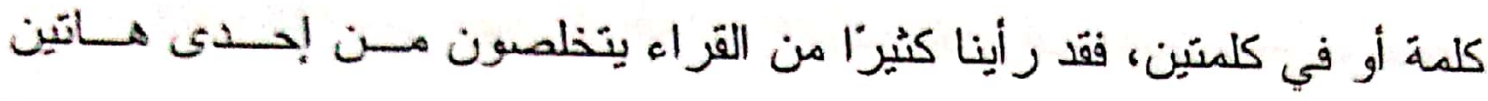

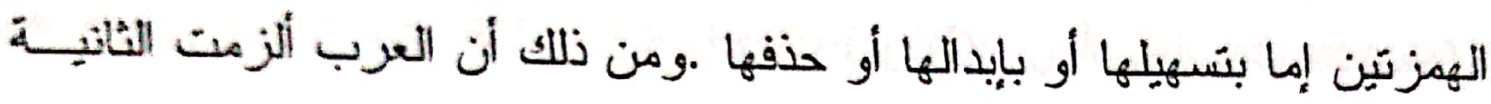
البدل في نحو: آدم وآخر، ولما كسروا وحقروا جعلوا هذه المبدلة بمنزلة ما لا لابلابل

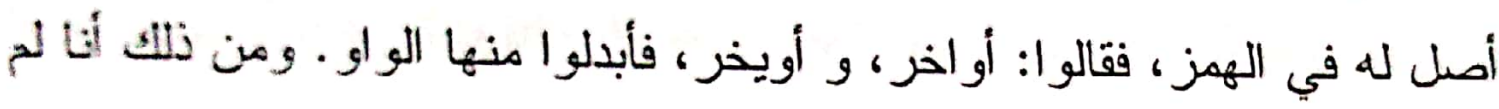
نجد كلمة عينها همزة و لامها كذلك، كما وجدنا ذلك في سائر أخوات الههزة من الحروف الحلقية، كقولهم : يدع اليتيم، و ألح في الطلب، ونحوه. ومنه أيضنا لُّهُم ألزموا باب رزيئة وخطيئة عما يودي إلى اجتماع همزتين فيه، فقالو إخليــا

ومنه أنهم إذا بنو السم فاعل من شاء.وجاء، قالوا : شاء وجاء، قُقضو! الجمع بينهما في هذا الطرن كما رفضوه أولا في آدم و آخر، إلى غيز نلى يـا يبين كر اهة العربب اجنماع الهمزتين، وميلهم إلى التخلص هذبه ("). 
كما أن من القر اء هن أخذ بتسهبل الهمز المفرد في الكلمة الواحدة نحو نافع (يؤمنون) و أمثاله، وقر اعة أبي السوار الغنوي (هياك نعبل وهيالك نسينسين بالهاء في موضع الهمزة فيهما.

ويمكن أن يعترض على ذلك بأن تارك الهمز فـــي (يؤمنسون) بهـهز (الكأس )، و (الر أس)، و (البأس) . ويجيب ابن خالويه عن ذلك بأن هذا أسماء، و الاسم خفيف، وتلك أفعال و الفحل ثقيل، فهمز لما استخف وحذف لما استئل ("). ومن القزاء من يههز إذا أدرج و لا يهمز إذا وقف، وبيطـرح حركة الهمزة على الساكن قبلها أبدا، فيقرأ إذا وقف (مويلا)، و (أصحاب المسشئمة )، ومنه (نجزا) لأن هذه الأحرف في السواد كذلك، فأما قوله( هزوا)، و (كفــا) فبالو او، لأنها ثابتَة في السواد.

ومنهم أيضّا من بحذف الهززات ساكنها أو منحركها وينقل الدركة إلى

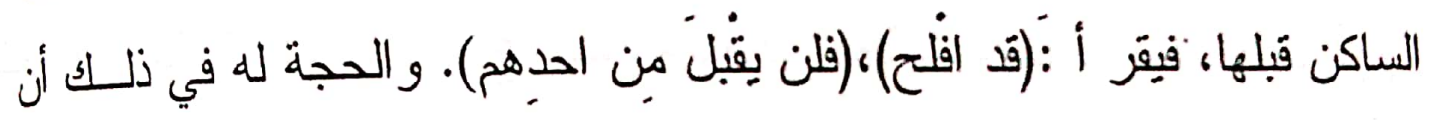
الهمزة المتحركة أنقل من الساكنة، فإذا طرحت الساكنة طلبًا للتخفيف، كانست

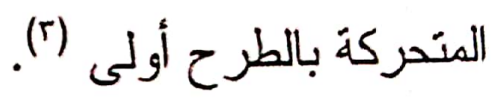
و القراءة بالتسهيل منتشرة بين القر اءو وأهل اللغة، وهي إنمــا نتكس ظاهرة لهجيةٌ واسعة الانتشار في بعض القبائل العربية كقريش وما جاورهـا، كهنيل وسعد بن بكر وكنانة، فإن هذه القبائل كانت تمبل إلى التخفيف.

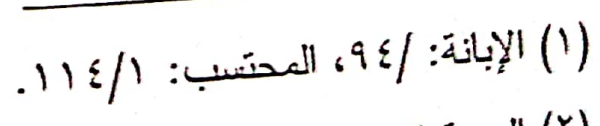

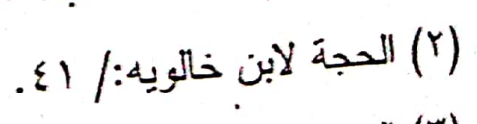

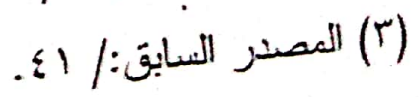


وقد نقل الرضي عن أمير المؤمنين علي رضي الهه عنه قوله: "تــزل

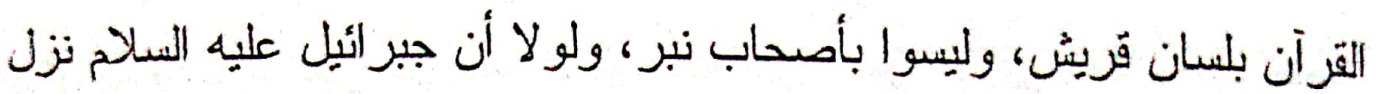

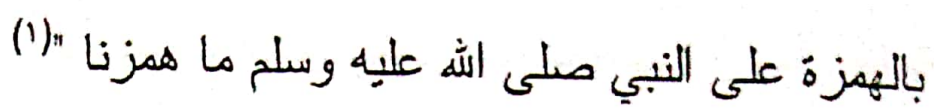

\section{- الاججاه الثاني: تحقيق الههز:}

\section{تحقيق الهمزتين ظاهرة لغوية موجودة لا سبيل لإنكارهـا، و النحقيـنق}

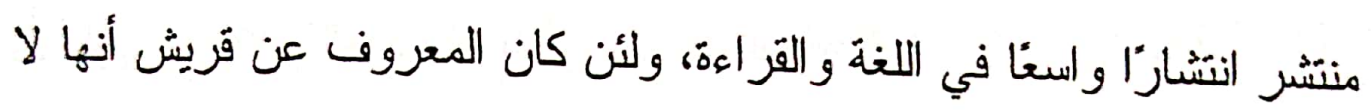
تههز، فإننا لو رجعنا إلى كتب اللهجات لتبينا أن جملة من القبائل العربية كان تهزز، فقد نقل القرطبي عن ابن عبد البر قوله" : قول من قال: إن القرآن نزل

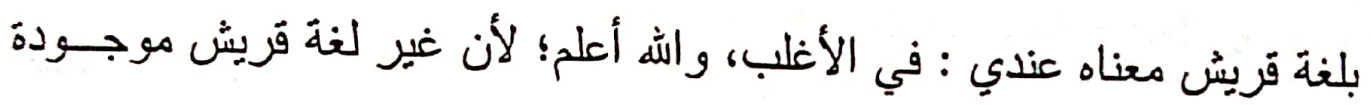
في صحيح القراءات من تحقيق الهمز ونحوها، وقريش لا تهمز" (r).

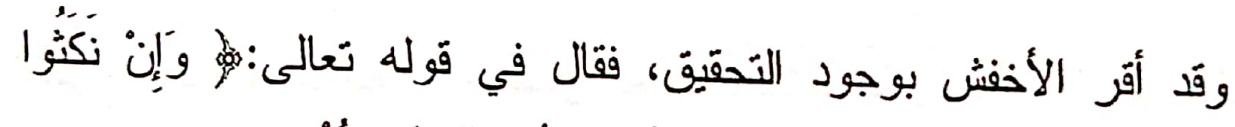

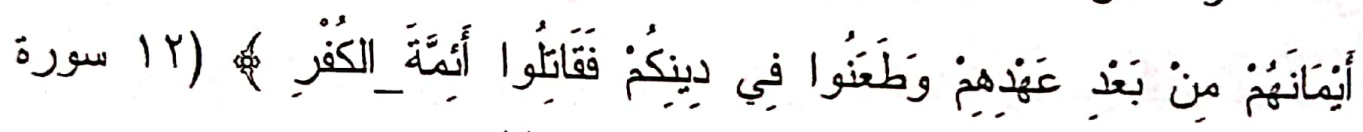

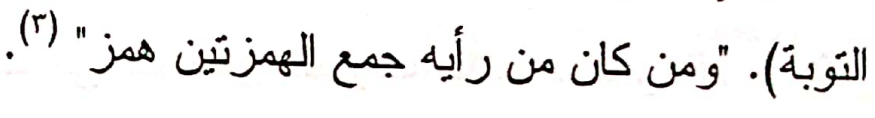
وقد جاء في الكثير من المصنفات، ومنها كتاب سييويه، تقسيم العرب

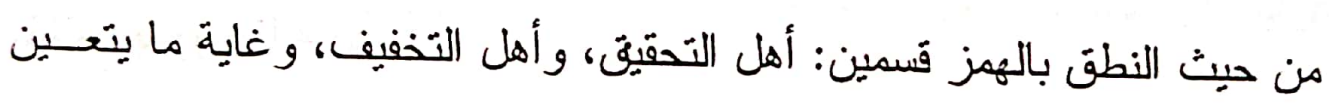

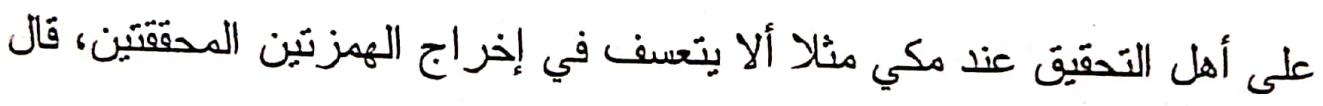

$$
\begin{aligned}
& \text { (1) شرح الثافية: r/r }
\end{aligned}
$$

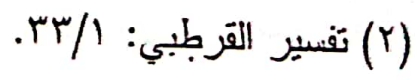

$$
\begin{aligned}
& \text { (r) معاني القرآن : }
\end{aligned}
$$

010 


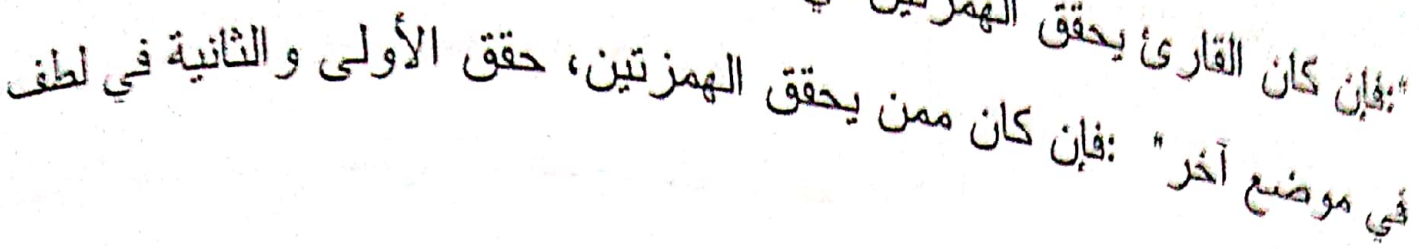

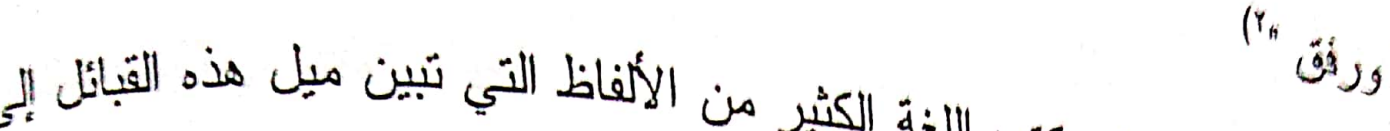

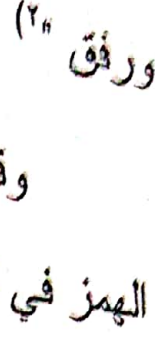

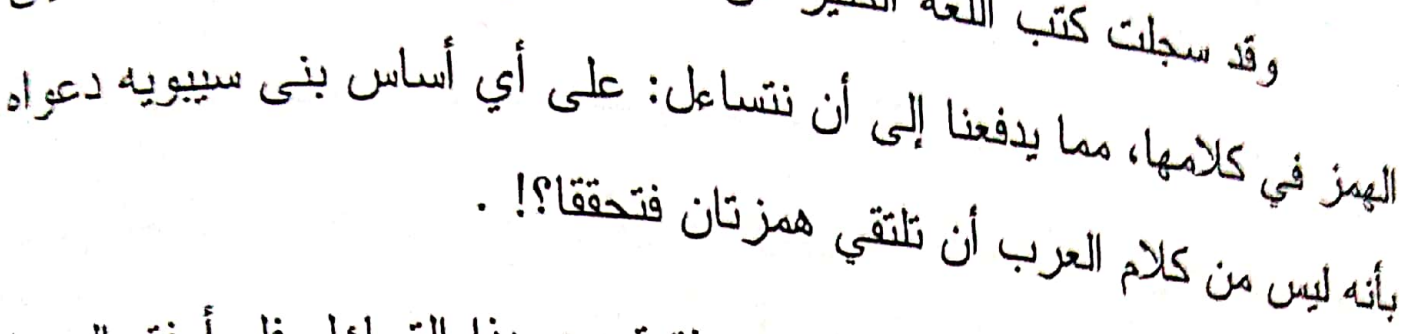

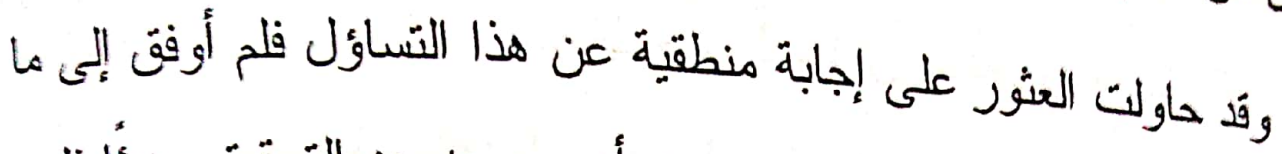

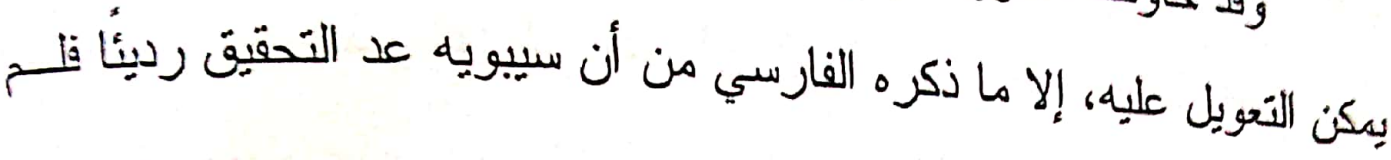

\section{يصنتبره.}

وحقبقة الأمر أن تحقيق الهمز هو الأصل في الكلام(r)، وأما التخفيــ

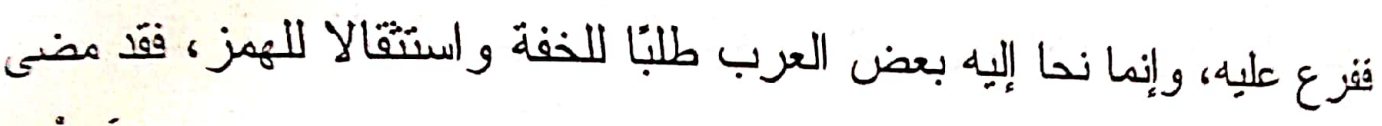

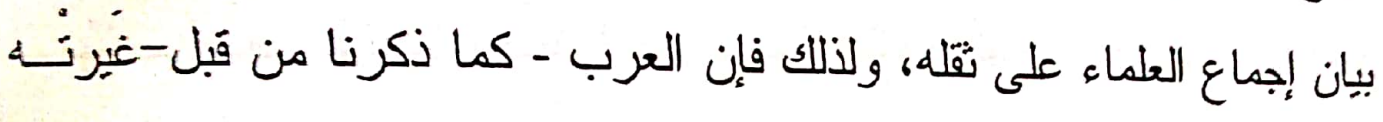

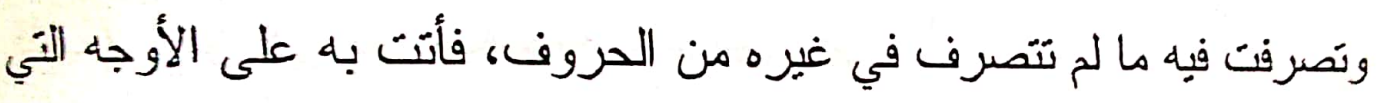
هر ذكرها، وعليه فلا عجب أن يقع في كلام العرب من غير أهل هذه القبائـلـ كلام مهوز ؛ فإنه الأصل.

$$
\begin{aligned}
& \text { (1) الرعاية: /9 ع 1. } \\
& \text { (ז) المصدر السابق. } \\
& \text { ("ا) الموضح: المدر السابن. 110/1. }
\end{aligned}
$$


ودليل ذلاك ما قاله الرضي حيث قال: "و التحقيق هو الأصسل كسنسائر

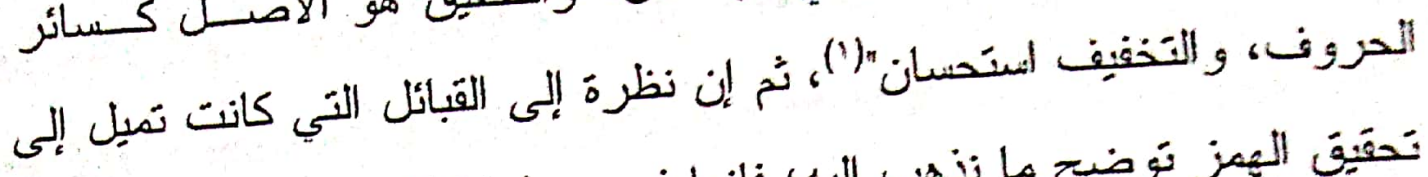

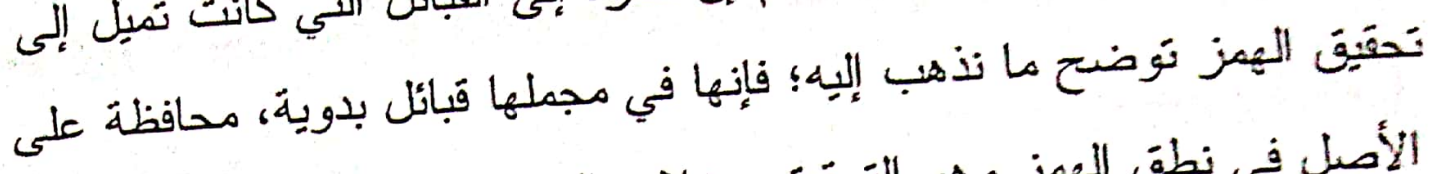

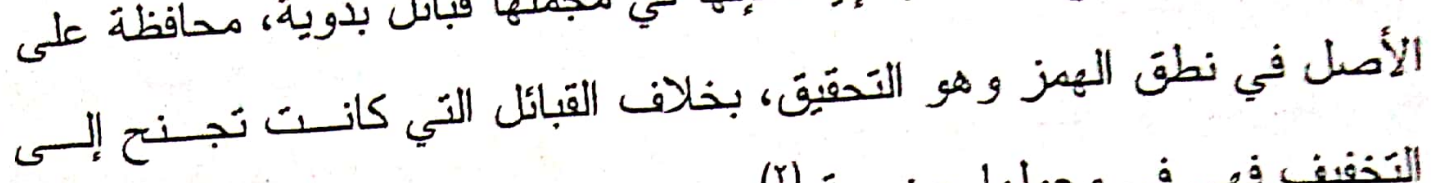
التخفيف في في مجملها حضرية (r).

على أن إيراهيخ السامرائي يرى أن تحقيق الهمزة قد يكون من عادات

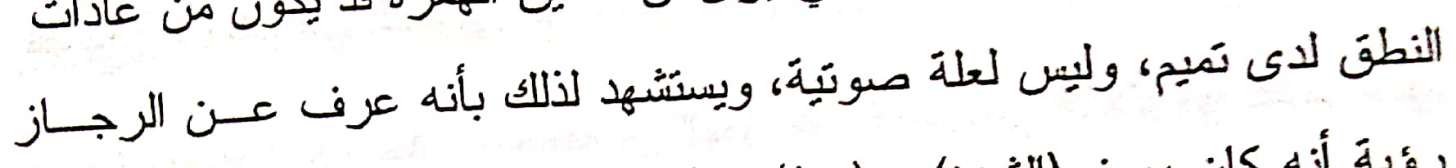

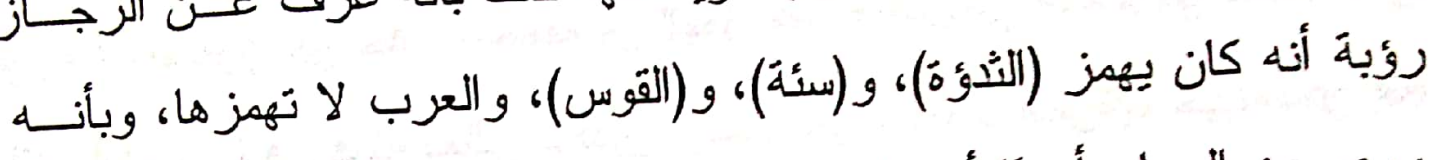

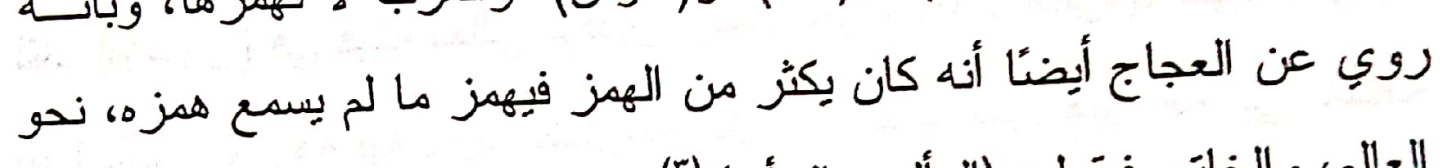
العالم، و الخاتم، فيقول: (العألم، و الخأنم) (r). بل لقد جاء في الصحاح ما يفيد أن الهمز مبالغة في الفصاحة: فقد نقل الجوهزي عن الفز اء قوله: "أنهم ربما خرجت بهم فصاحُهم إلى أن يهمزوا ما ليس بمهوز، وذلك في نحو قولهم: (لبأت بالدج) في مكان لبيت، و (رثأت الميت) في مكان رثيت، و (حلأت السويق تحلئة)، و إنما هو من الحلاوة (؛)، ورلا غزابة أن نجد من القراء السبعة من يهمز

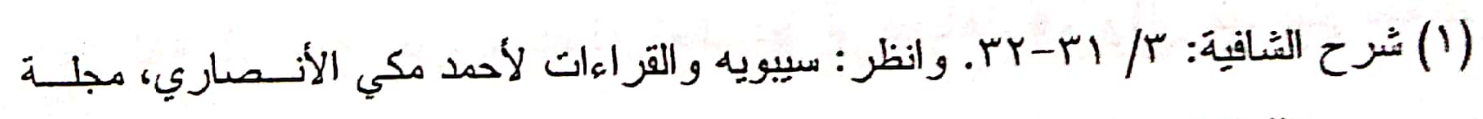
مجمع اللغةَ العربية بالقاهرة جع ب- نوفمبر ع 9 ام.

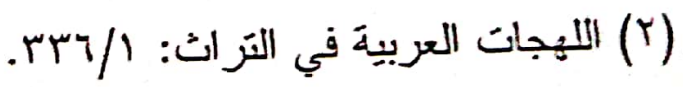

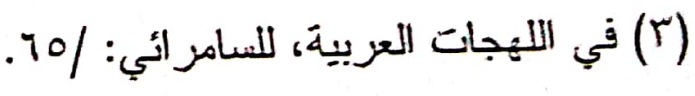

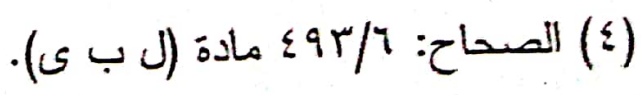




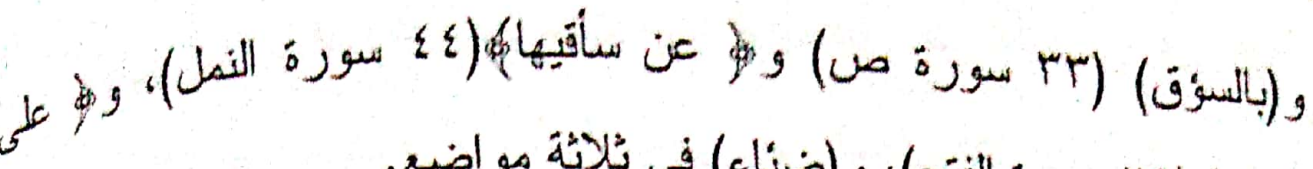

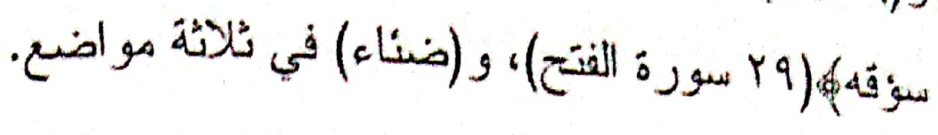

وقد همز كل من أبي عمرو و الكسائي وأبي بكر عن عاصم (التأئ)

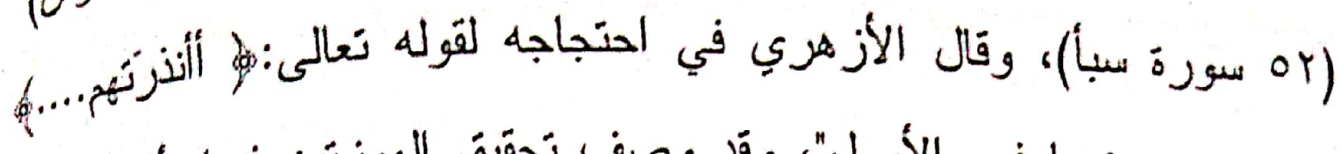

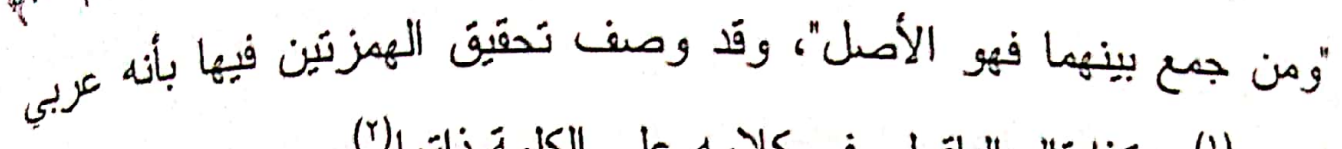
فصيح("). وكذا قال الباقولي في كلامه على الكلمة ذاتها('). ويقرر ابن خالويه حقيقِة أن الهمز هو الأصل في الكلام في كلامه على في

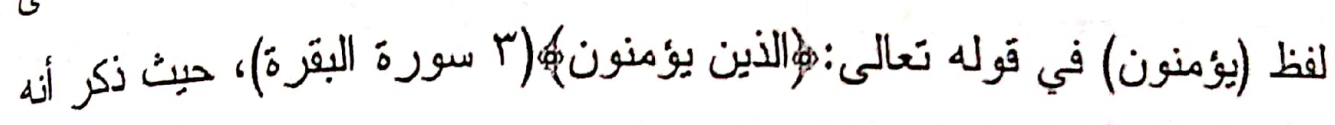

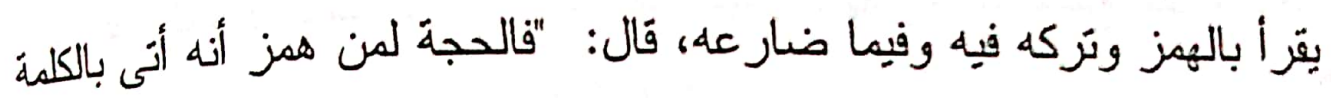

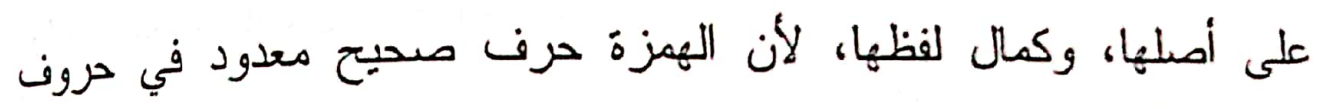
المعجم، والحجة لمن تركه أنه ندا التخفيف، فأدرج اللفظ، وسهل ذلك للك عليه

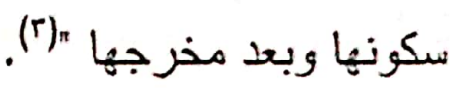

وعليه فإن تحقيق الهمز في تراءات القراء ممن هم من أهل التخفيف

إنما هو راجع لأسباب معلومة غير خافية، هي في الأعم الأغلب لطلب الذفة،

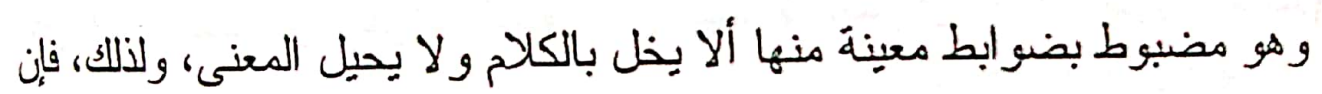

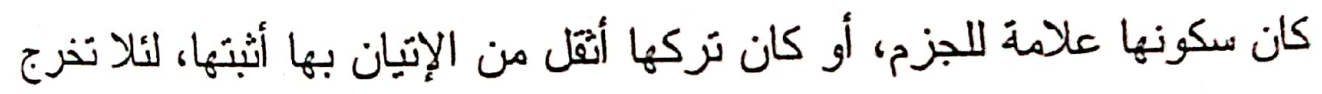

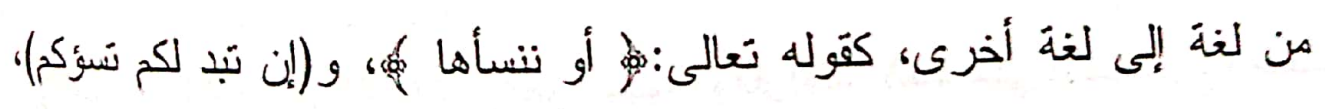

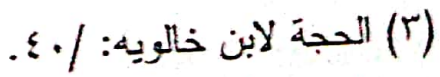




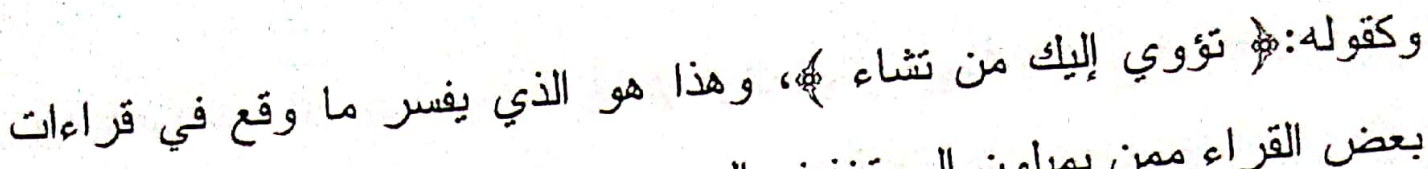
بعض القراء ممن بميلون إلى تخفيف الهمز من التحقيق في مو اضع بأعيانها.

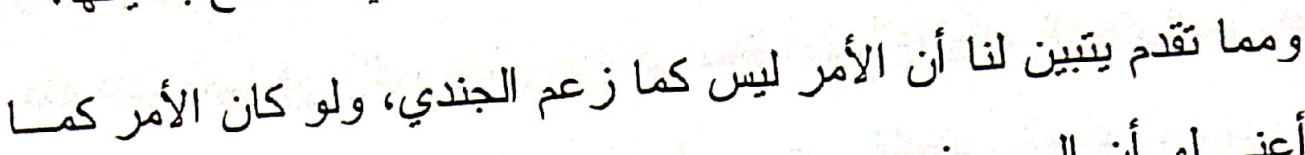

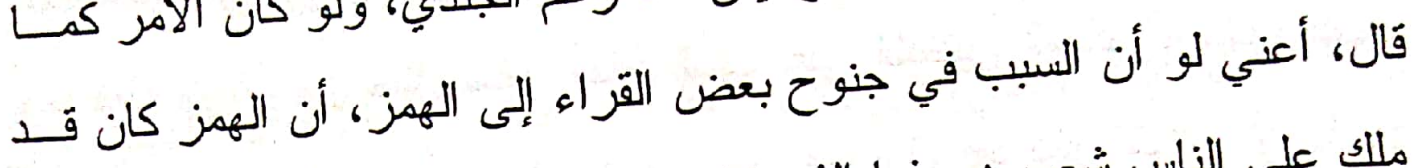

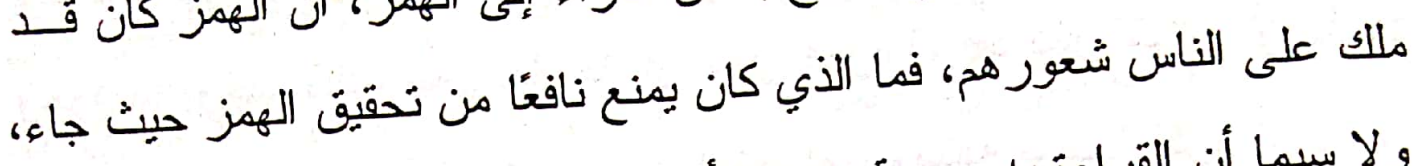

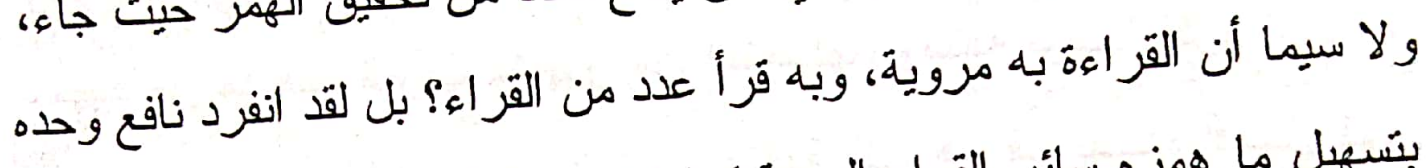

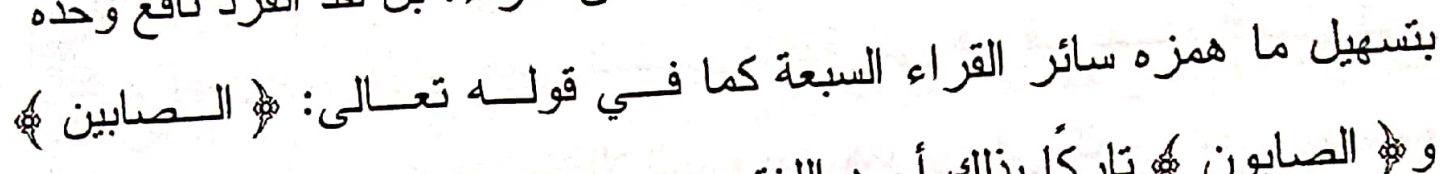

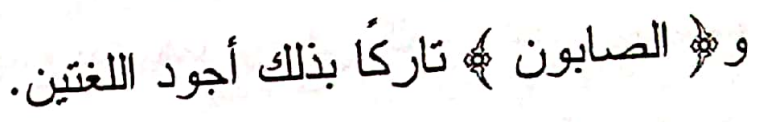

على أن المواضع التي روى فيها ورش عن نافع التحقيق معدودة، ولو

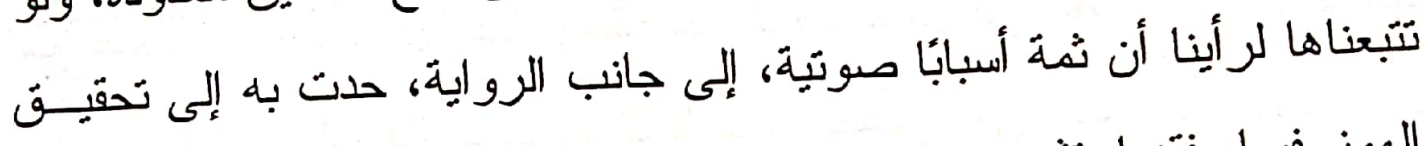

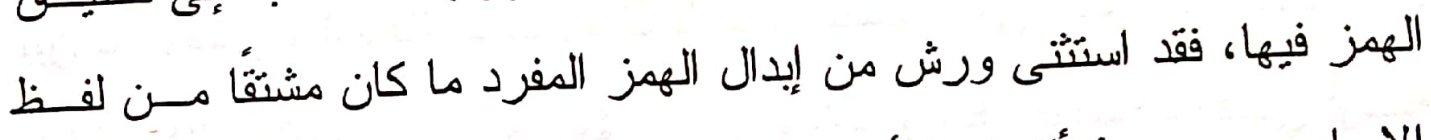

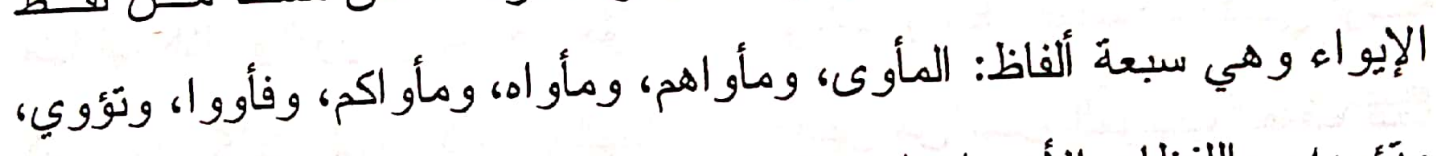

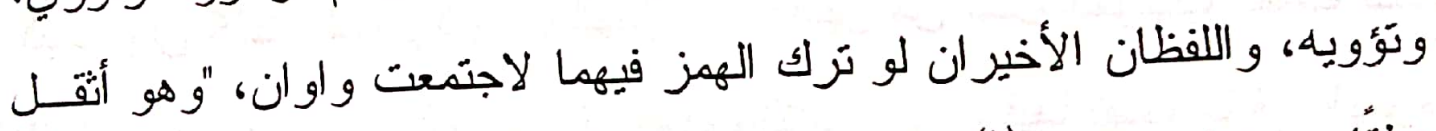

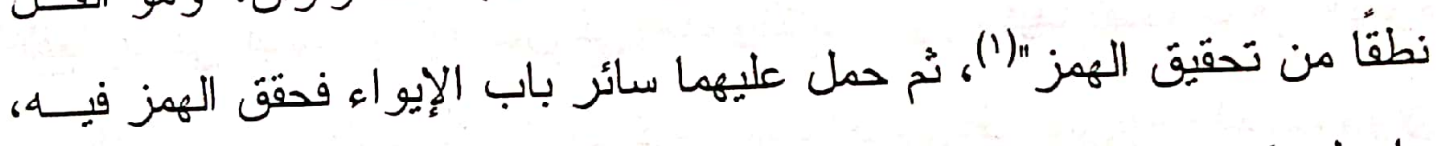
و إن لم يكن في ذللك من العلة الموجبة لإتيانف الهمز ما فيهما، ليكون الباب كله بلفظ و احد، و على طريقة و احدة.

وقد نقل صاحب شرح الارر اللوامع في أصل قر اءة الإمام نافع عـن الاني قو له في إيجاز البيان: "و أما الرواية بالهمز فوجهها من طريق النظر، أنه لما أجمع الرواة عن ورش على تحقيق الهمز في قوله نعالى: (تؤوي) و (تؤويه) 


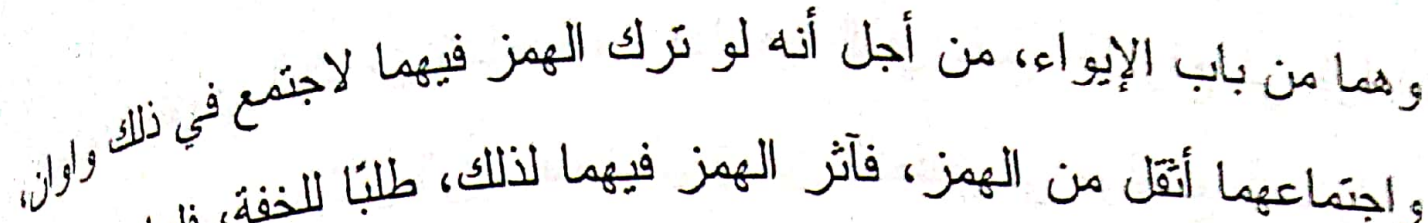

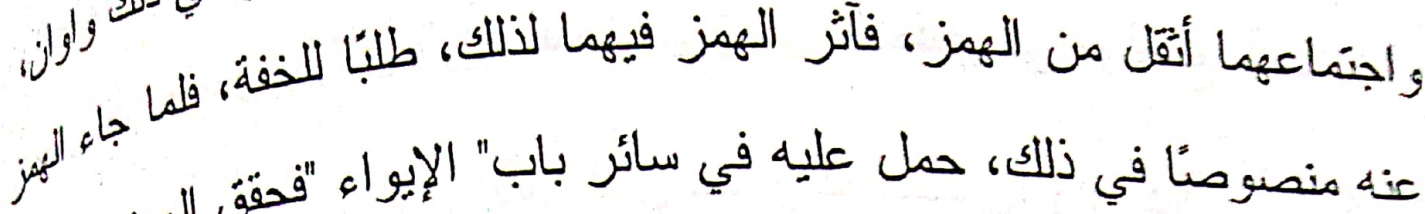
عنه منصوصنا في ذللك، حمل عليه في سائر باب" الإيواء "هحقق الهمز فبرا") وما فعله ورش من حمل سائر ألفاظ الباب على اللفظين المذكورين من غير وجود ما يوجب ذللك، ليس خارجًا عن سنن العربية، فقد ذكر الاني أن ذلـا

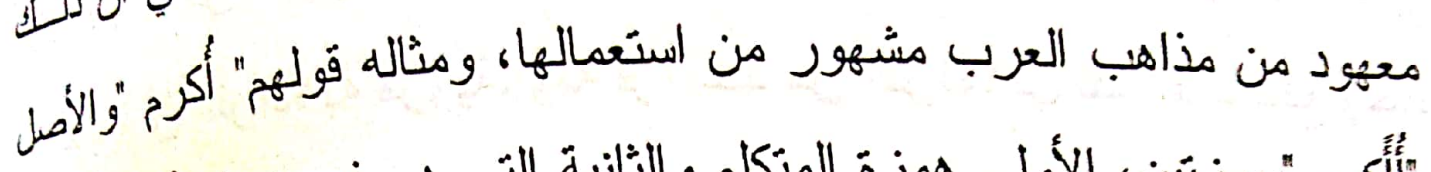

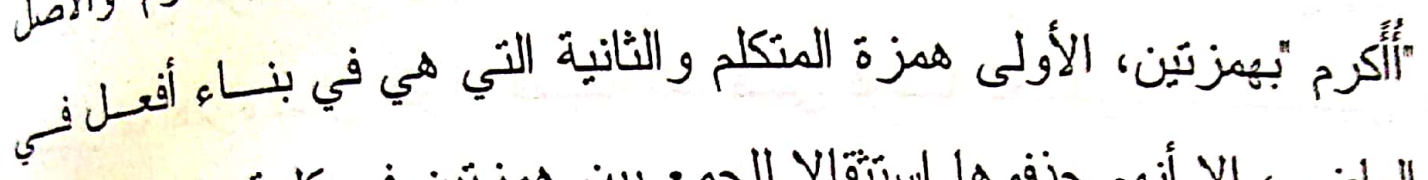
العاضي، إلا أنهم حذفو ها استثقالا للجمع بين همزتين في كلمة واحدة، نُ حلار

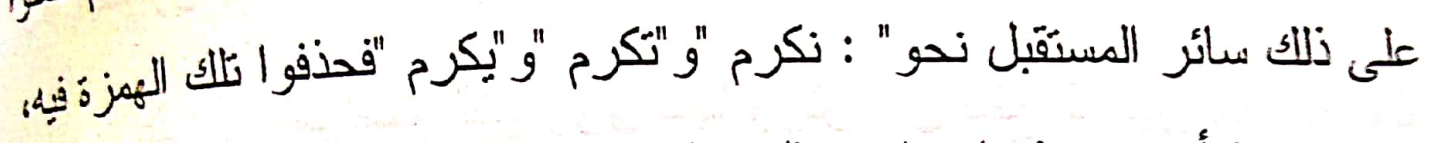

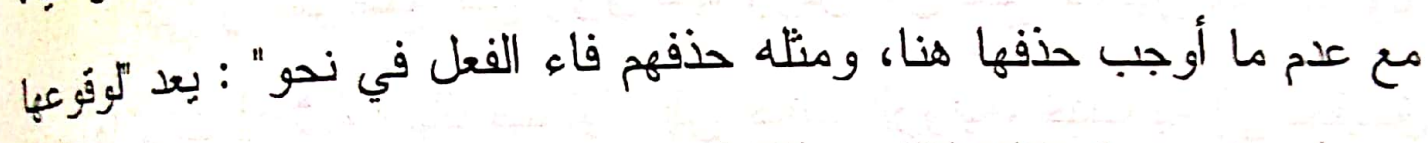

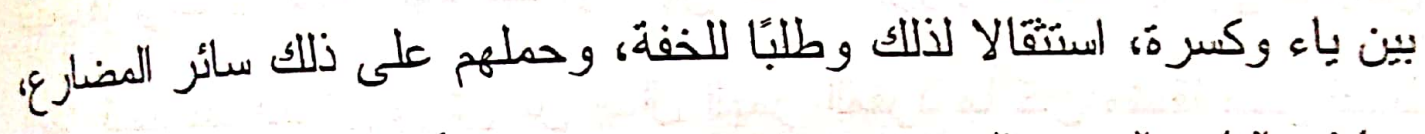

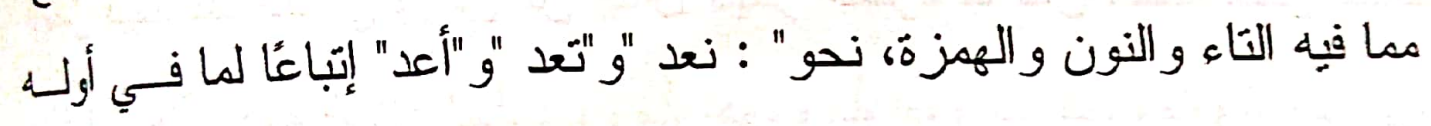

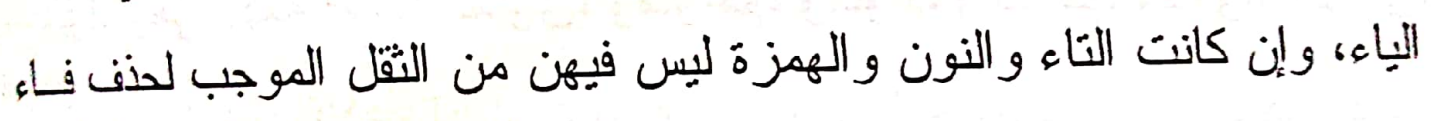
الفعل ما في الياء، كما أنه ليس في الياء و التاء و النون، فيما ثقام، ما في الهززة

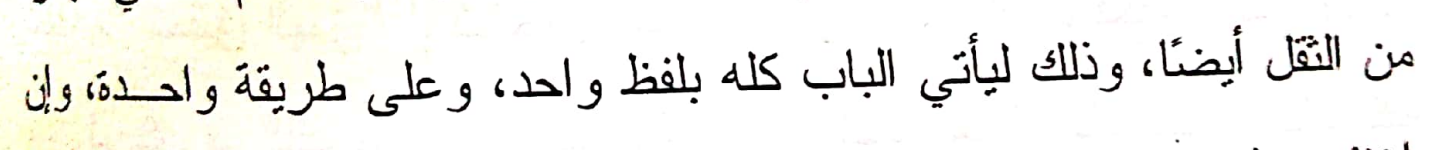

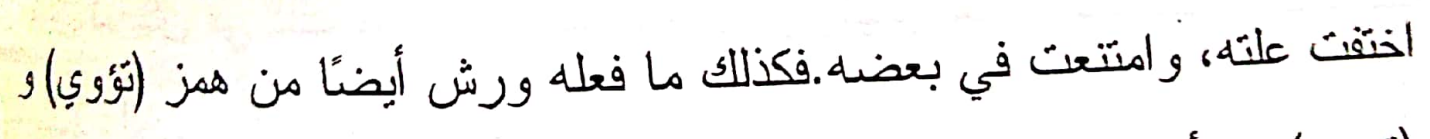
(تؤوبيه) من أجل الاستثقال لاجتماع الو اوين، وحمله على ذلك (المأوى) ونظائزه

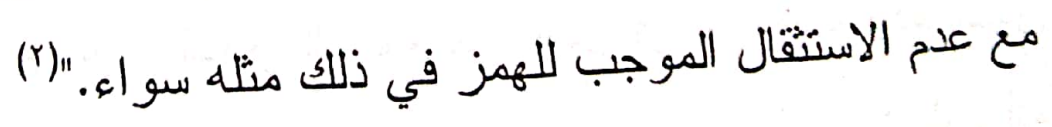

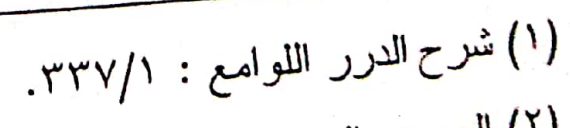

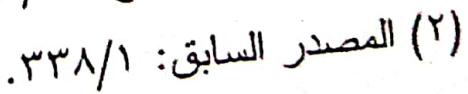


وبطلب الخفة علل ابن بري ما وقع في رواية ورش من تحقيق همسز

الإيواء، فقد جاء في أرجوزته الموسومة بالارر اللوامع في قراءة نافع فوله:

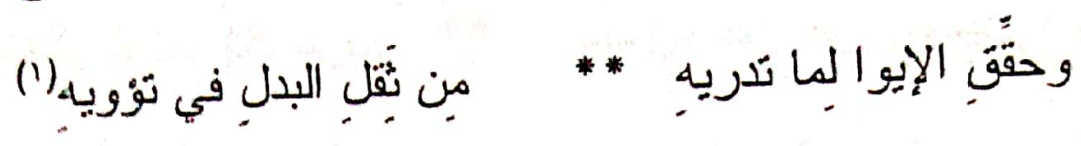

و أما همز (النبي) فقي كتب اللغة أن الأصلَ في هذه الكلمة الهمز ، وإن

كان أكثر العرب على ترك الهمز فيها، و إنما تركته العرب لكثرة الاستعمال، فقد

نقل ابن دريد عن أبي عبيدة قوله: "تركت العرب الهمز في أربعة أشياء: فـي الخابية، وهي من خبأت، و البرية وهي من برأ الله الخلق، و النبي وهو من النبا، و الأرية وهي من ذرأ الله الخلق(ب)."

وفي الصداح: "تركوا الهمز في هذه الأربعة، إلا أهـلـل مكـــة فــإنهم

يتهزونها، و لا بهمزون غير ها، ويخالفون العرب في ذلك"(r).

ونقل عن ابن السكيت: "قال يونس: أهل مكة يخالفون غيرهم من العرب

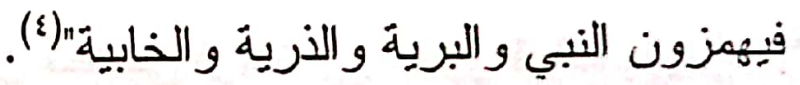

ففضلا عن كون الهمز في كلمة (النبي) هو الأصل، فإن هذه الأخبــار تقطع بأنه كان بيطق بها مهموزة أهل منطقة برمنها، وهي مكة التي هي جزء من الحجاز التي تخفف الهمز، فنافع إنما أخذ بالأصل في هذه الكلمة ويشفع له

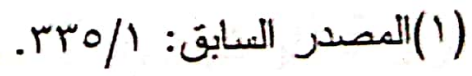

(Y)

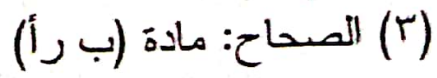

(5) المزهر: ror/r. 
أن أهل مكة، كما تقيد الأخبار، كانو اينطقون بها كذلك، وأن من العرب هن كلر بِمع النبي على النبئاء، كما جاء في قَول عباس بن مرداس:

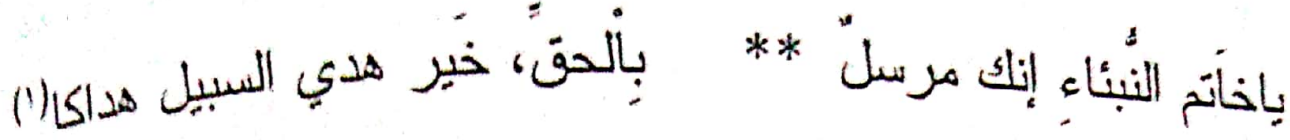

ولننتقل إلى قارئ آخر كان بجنح في قَ اعته إلى تخفيف الههز ، وهو أبو

عمرو بن العلاء، فإن له في الهمز مذهبين : التحقيق و التخفيف، ثال الــاني : أليا

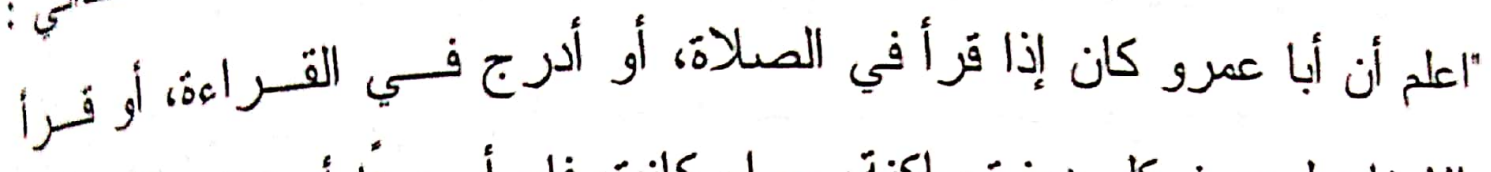

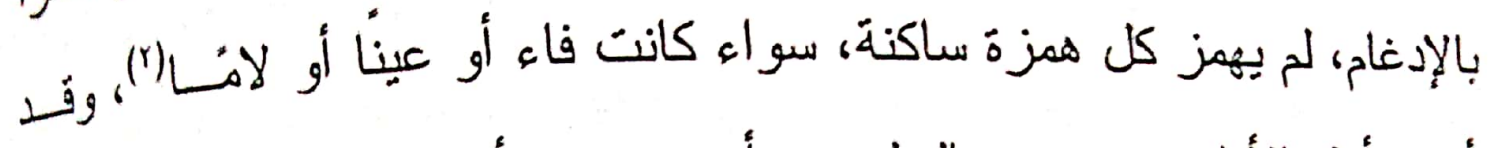
أجمع أهل الأداء ممن روى البدل عن أبي عمرو، أنهم استثثوا خمس عسشرة كلمة في خمسة وثلاثين موضعا، فهل كان تحقيق الهمز فـي هـــه المواضسى

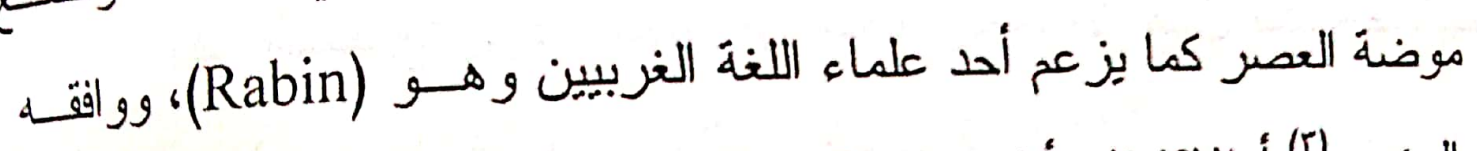

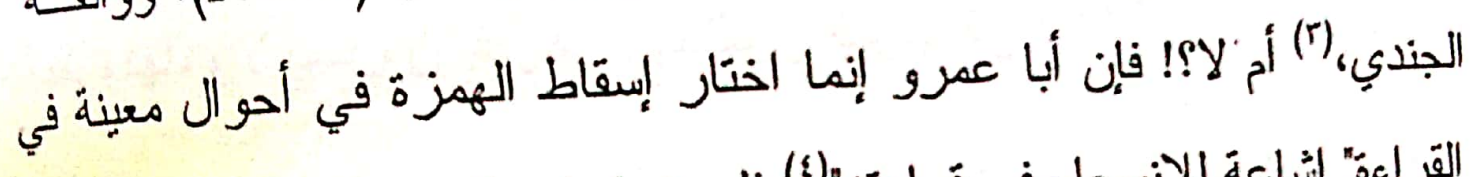

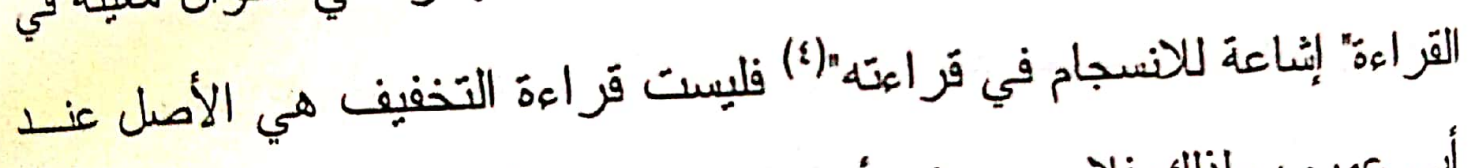

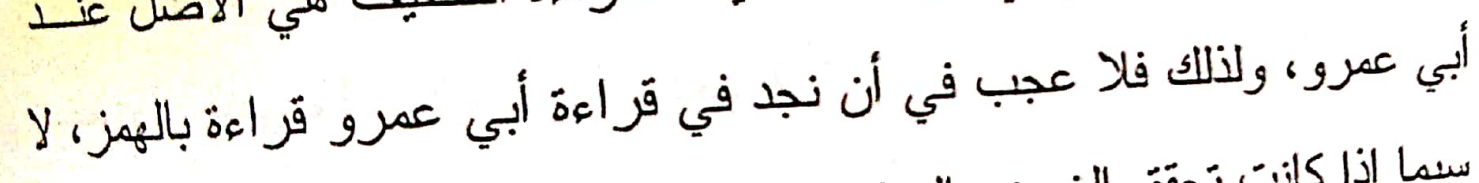

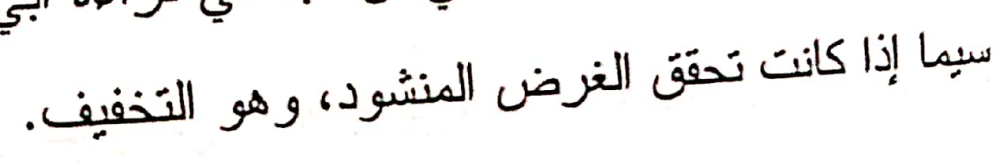

ولنتظر إلى ما جاء في كتب القزاءات من تعليل اختيار أبسي عمــرو

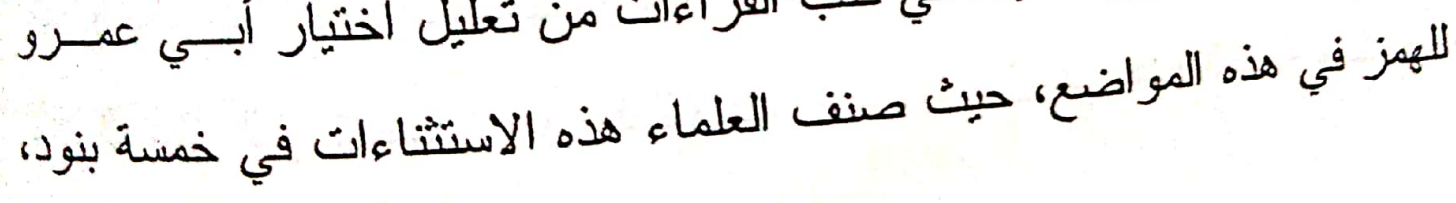

$$
\begin{aligned}
& \text { (1) البيتَ في ديوانه : / / 90، لسان العرب مادة (ن ب أ). }
\end{aligned}
$$

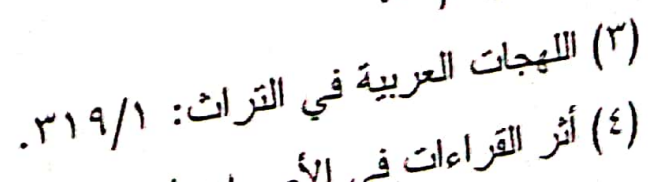

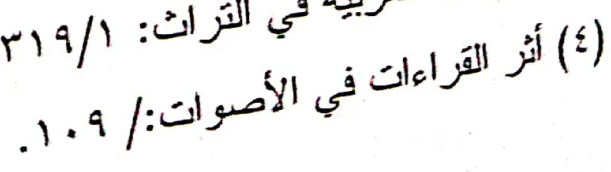


وبينوا أسبابًا لتحفيق الههز في هذه المو اضع، يؤيدها المنطق اللغوي وتـسندها. الرواية القر آنية، وهي كما يلي: ا- ما سكونه علامة جزم:

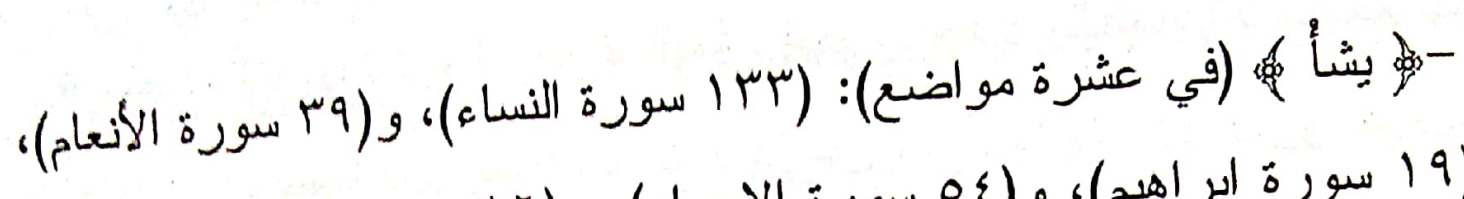

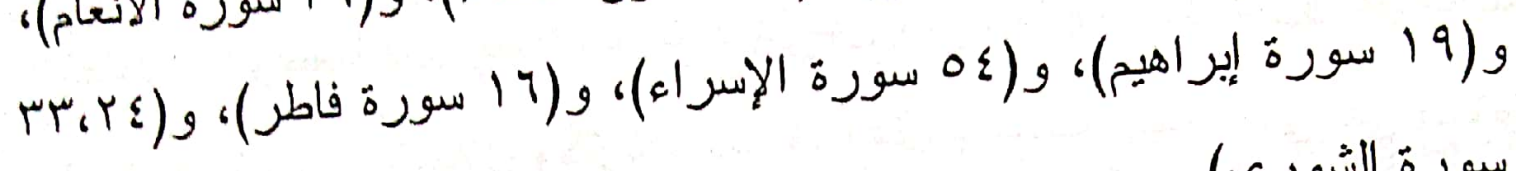

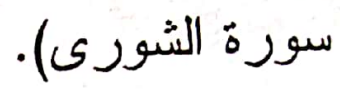
سورة يس) - (- سون.

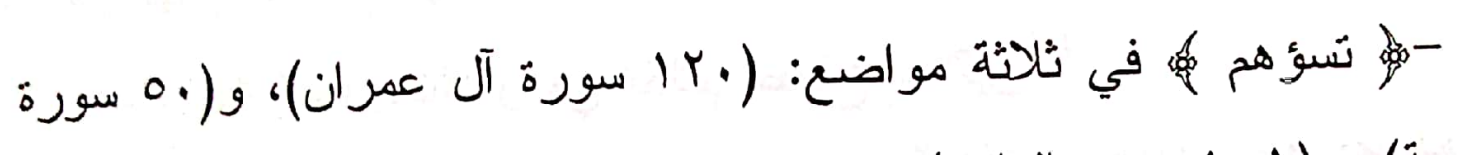
التوبة)، و(1 · ( سورة المائدة). -

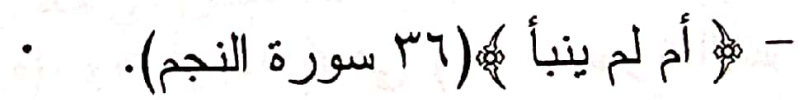
و استثنى أبو عمرو المو اضع التي سكونها علامة للجزم، لأنه كره ترك الهمز فيما سكوُنه علامة للجزم كر اهة التباس المعرب بالحركات بالمجزوم، ألا تزى أنه لو قال: (أو ننساها) لالنبس بما يكون من النسيان الذي هو ضد الذكر أو الذي هو بمعنى الترك، و إذا الثبس بذلك صار الفعل كأنه معرب، إذ لو كان مجزومًا لكانت علامة الجزم سقوط الألف، و الكلمة على قر اعته معناها التأخير ، 
لأن معنى (ننسأها) نؤخرها، وهو مجزوم بالعطف على الشرط، فلما كان بره

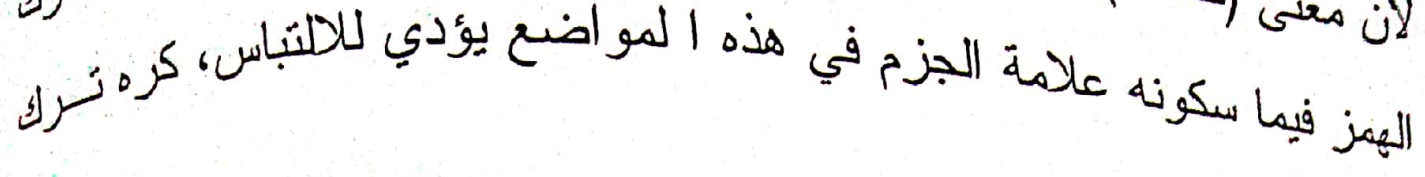
الهمز فيها. على أن ثمة سبيًا آخر للهمز في هذه الكلمة، وهو أن حركة الهمزة فيها

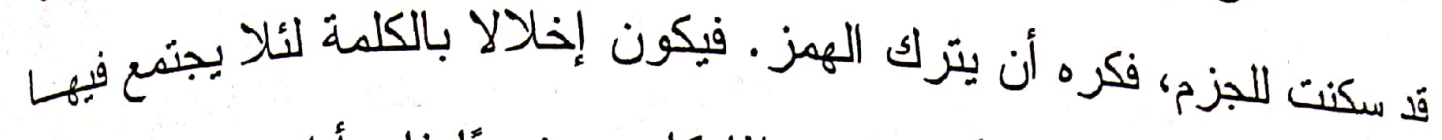

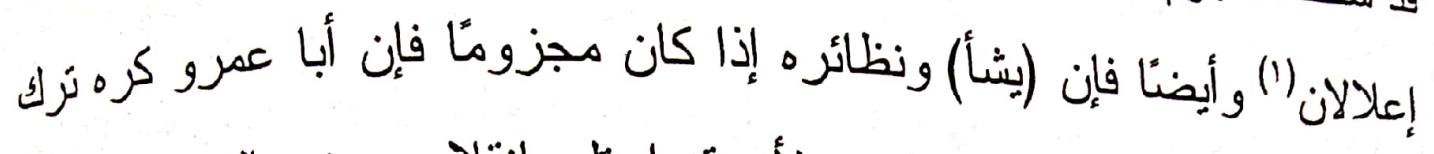

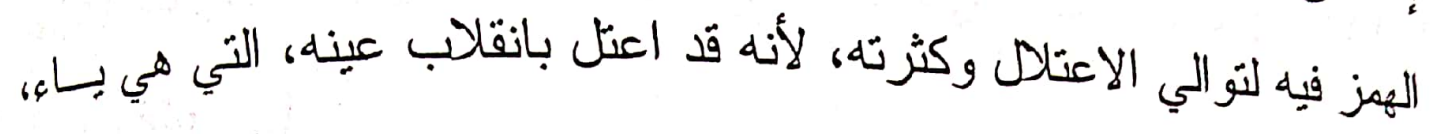
ألفاء فإن أصل الكلمة من المشيئة بالياء، ثم اعثل بسقوط هذه الألــف لالثماء الساكنين اللذين هما هذه الألف و الهمزة المجزومة، و اعتل أيضًا بحذف الحركة

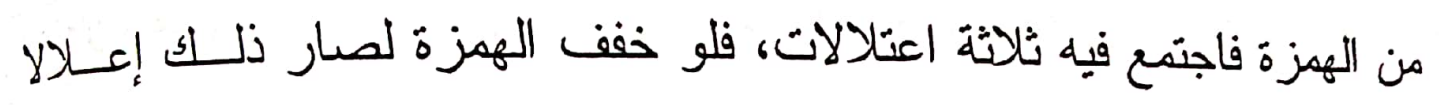

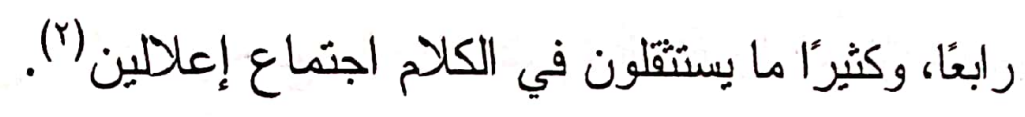
r- ما كان سكونه للبناء: وذلك في فعل الأمر من مثل الأفعال السابقة، وهو سبع كلمات في أحد عسشر موضعا:

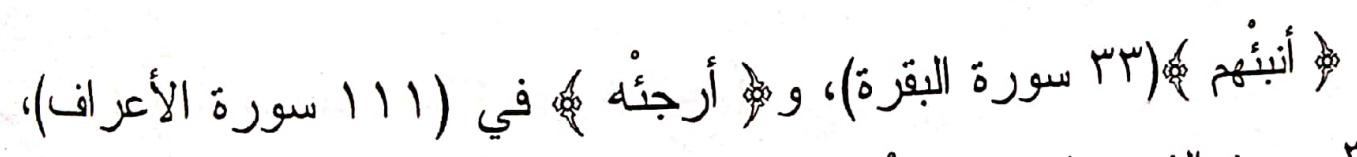

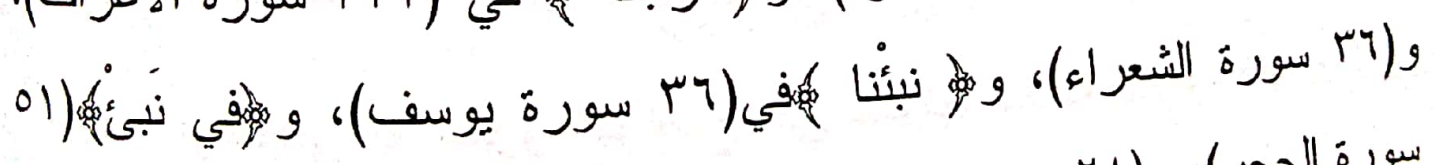

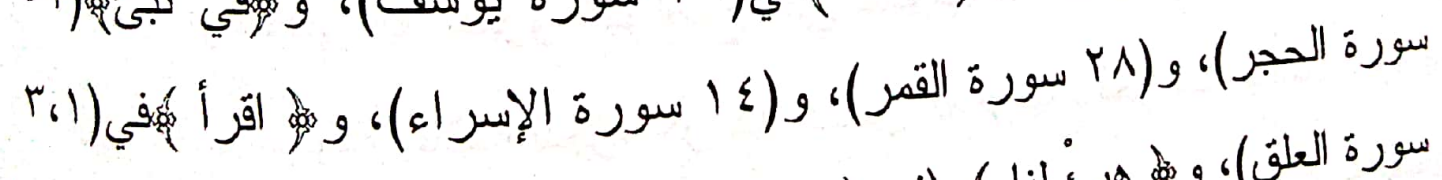

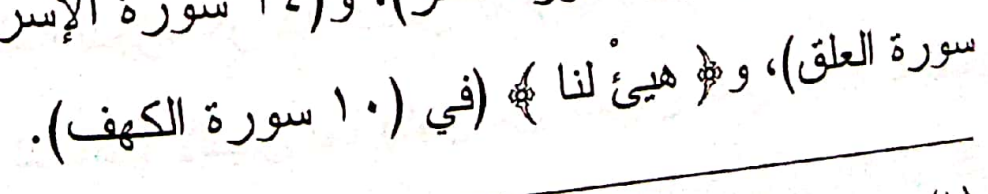
. (1)

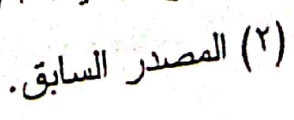




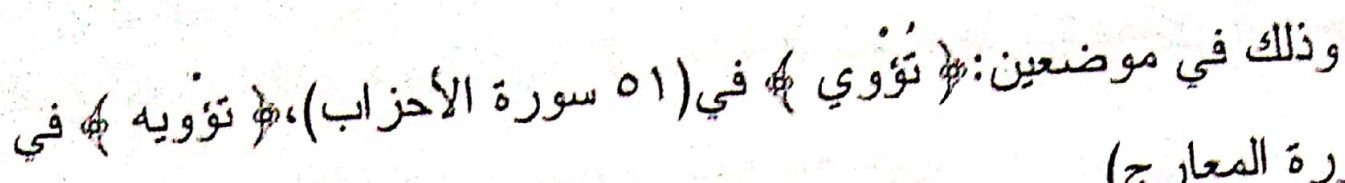

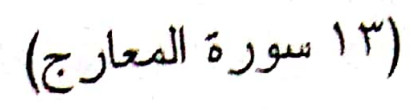

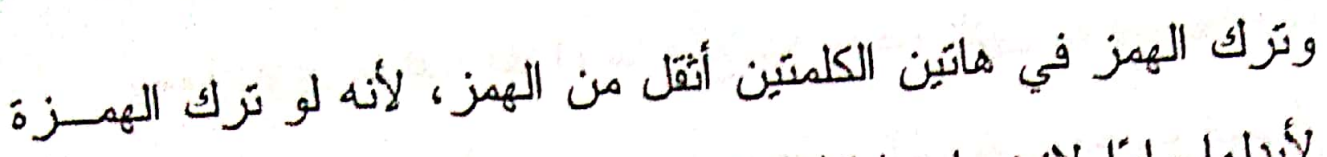

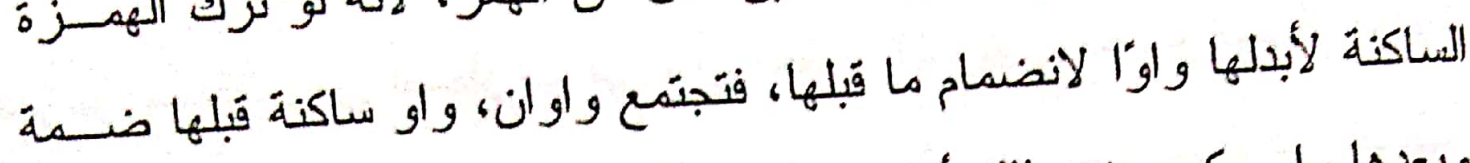
وبعدها و او مكسورة، وذذلك أقتل من الهمز (").

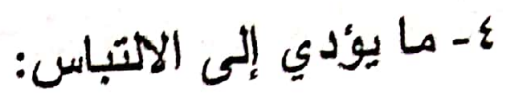

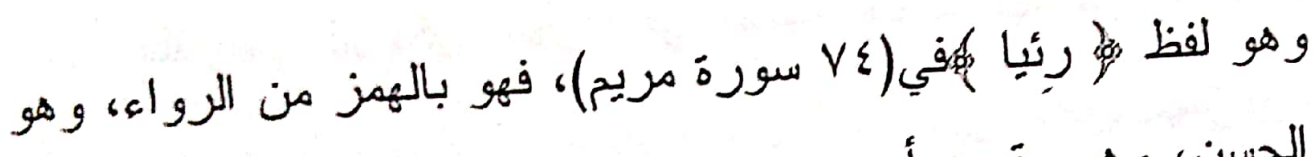

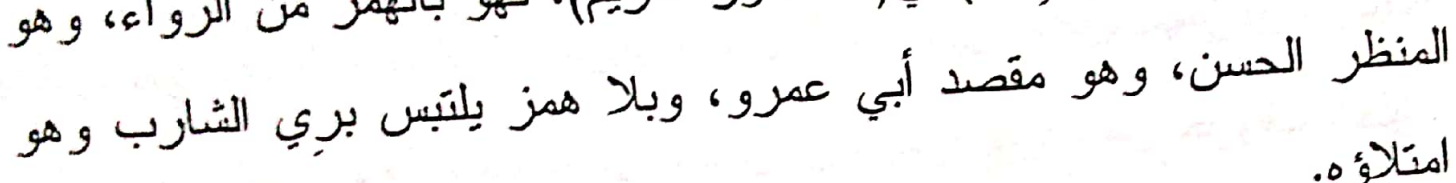
0- ما يخرج بتسهيله من لغة إلى أخرى:

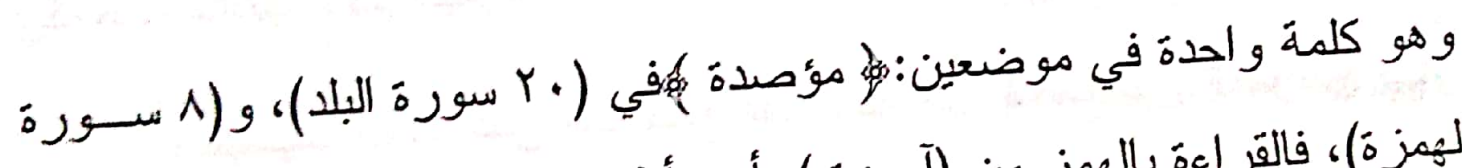

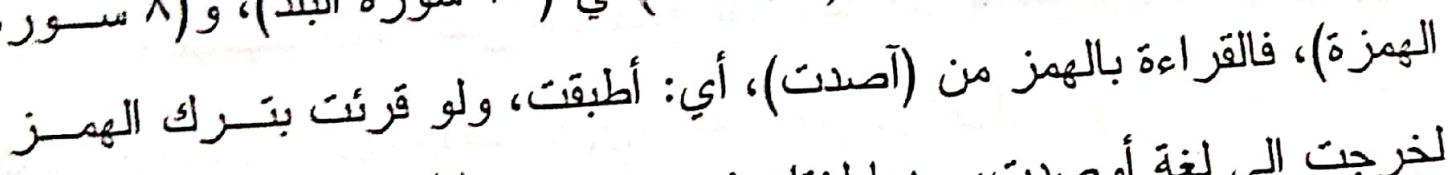
لخرجت إلى لغة أوصدت، وهما لغتان في معنى واحد (r).

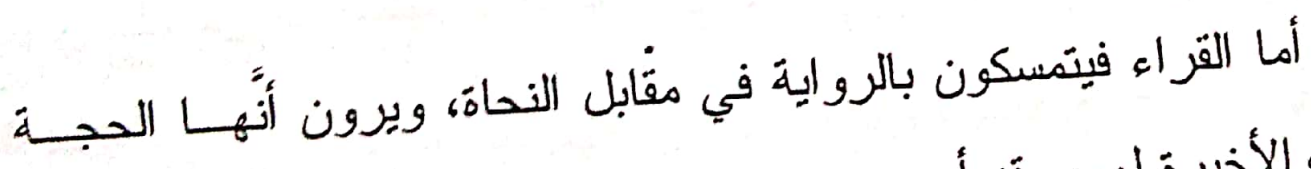

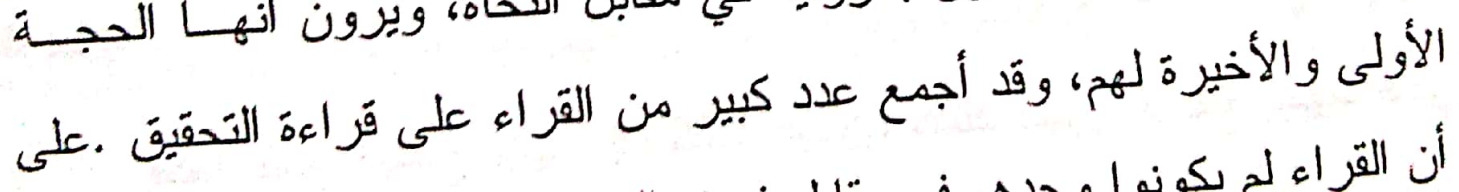

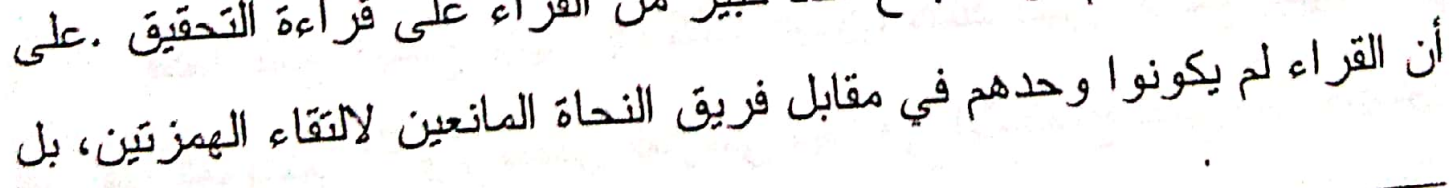




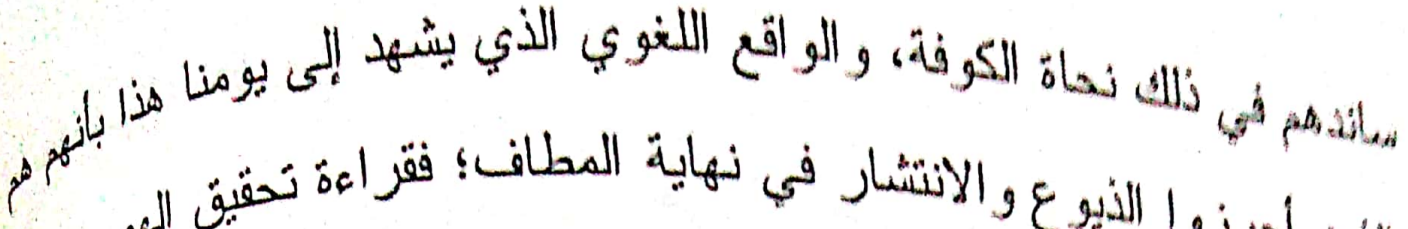

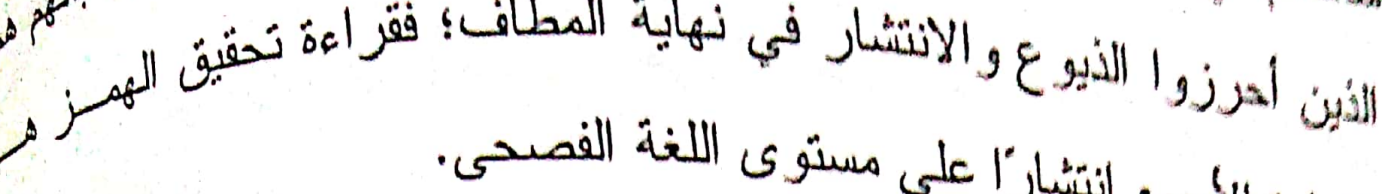

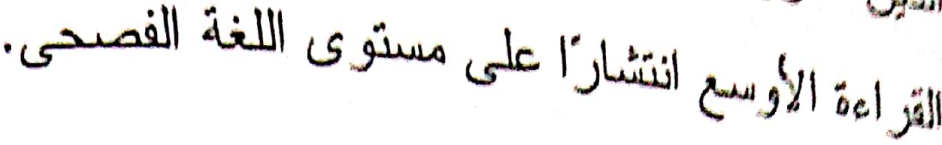

ومما يقوي موقف القراء ما وقع فيه النحاة الذين لم يجــوزوانهوالي هـزتين محققتين من اضطر اب في شان تحقيق الهمزتين، بحيث إنها لم بجرا. بذا من رد القراءات التي جاءت به. وقد بدا هذا الاضطر اب واضخافي كتبل الاحتجاج. ولا بأس أن نقف فيما يلي على طرف من ذللك:

فالفارسي لم يكن مطردًا في مسألة الثقاء الهمزتين وتحقبقها، فني

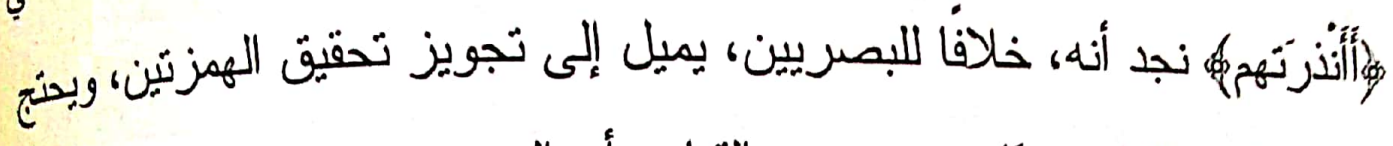
له بالسماع و القياس معنا، وحجته من القياس أن الهمزة حرف من حروف الحلق،

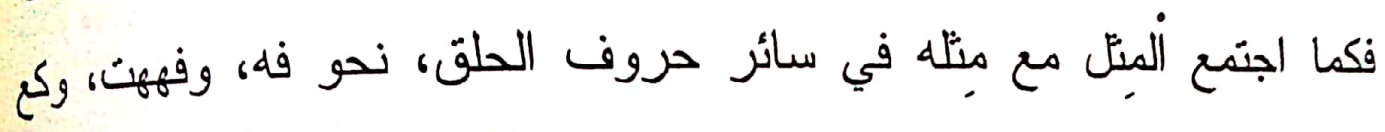
وكعتَ، فكذللك حكم الهمزة.

ويقِسهما أيضًا على المواضع التي وقع فيها الجمع بين الهمزتينّ في

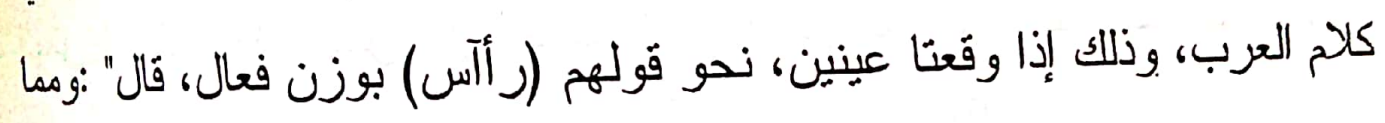

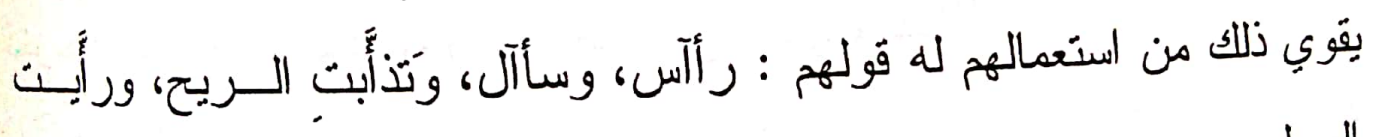

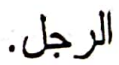

فكما جمع الجميع بينهما إذا كانتا عينين، كذللك يجوز الجمع بينهما في

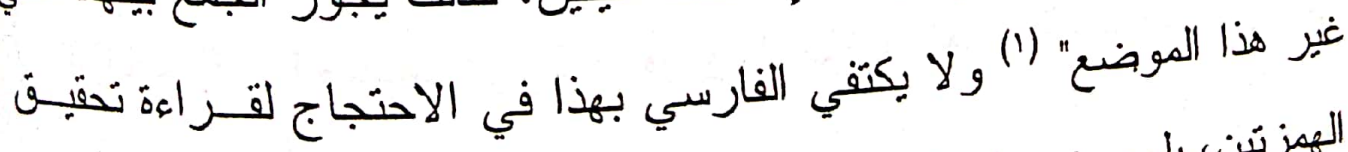

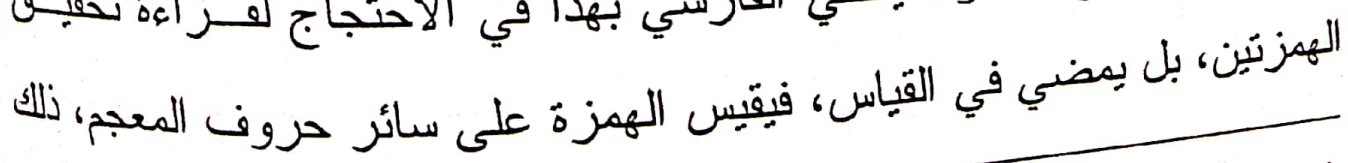

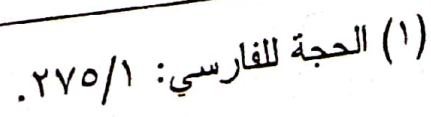




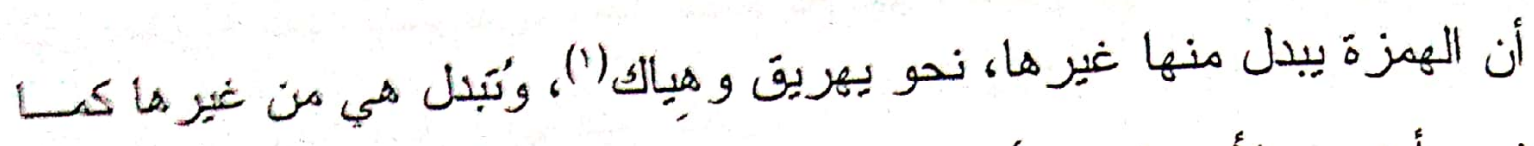

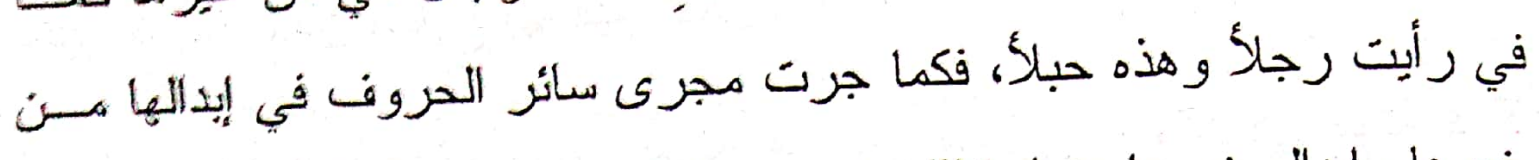
غير ها و إيدال غير ها منها، كذلك تكون سبيلها في اجتماعها مع منتها، كما اجتَّع سائر الحروف مع أمثنالها.

وأما في تحقيق الهمزتين من كلمة (أُمْمة) فإننا نجد الفارسي يِّلب الأمز

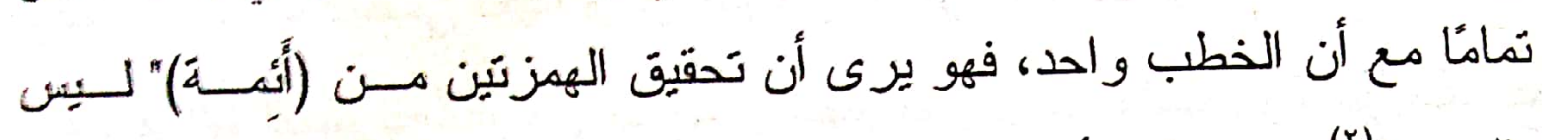

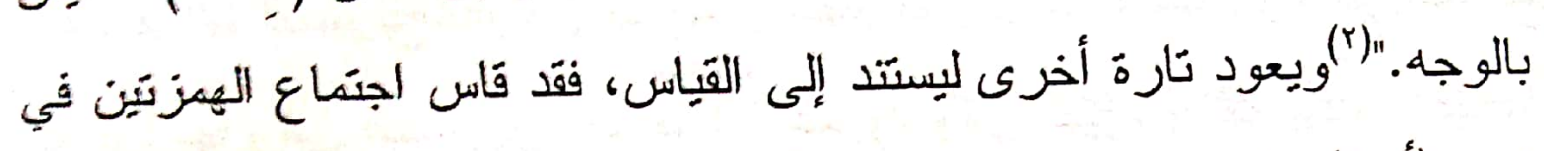

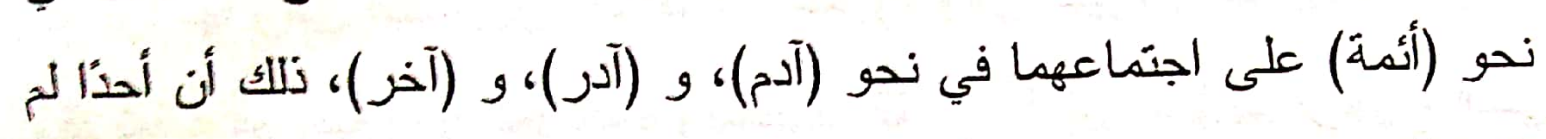
يقل بالتحقيق فيهما في هذه الأمتلة.

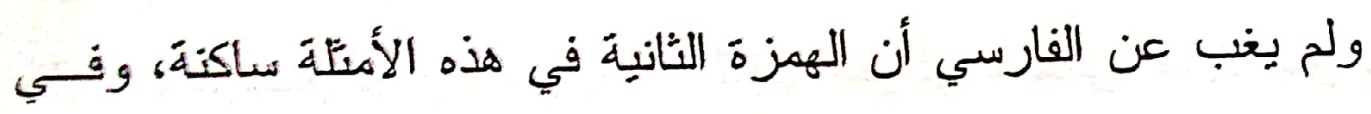

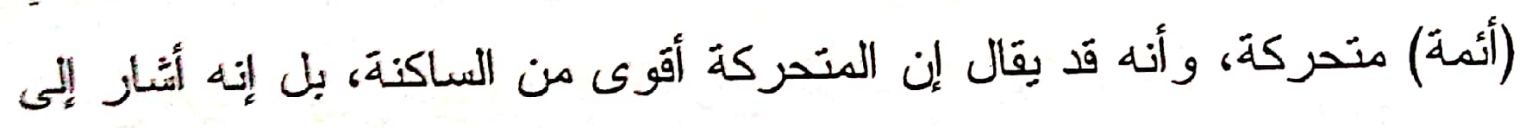

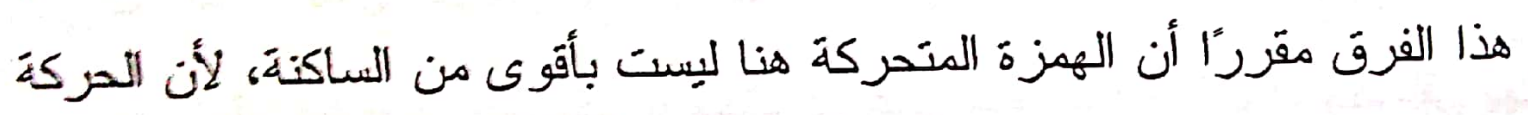
التي فيها لم نكن مانعةَ من الاعتله (5).

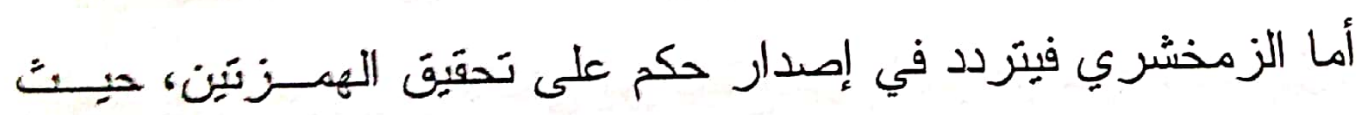

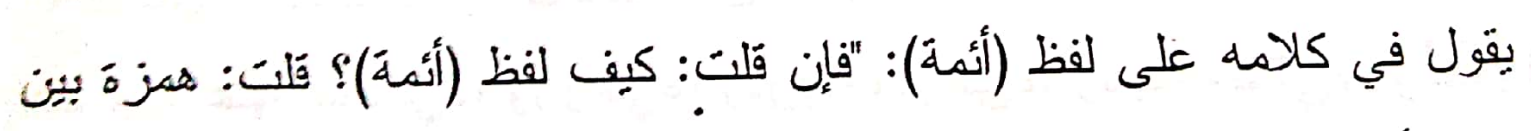

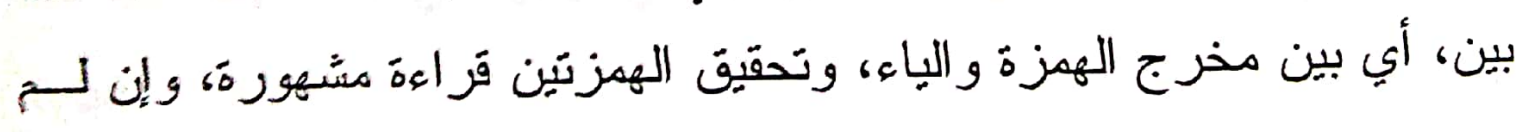

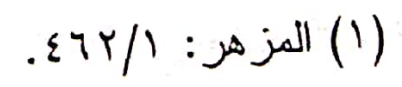

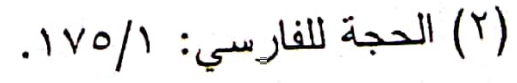

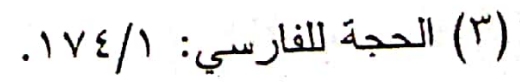




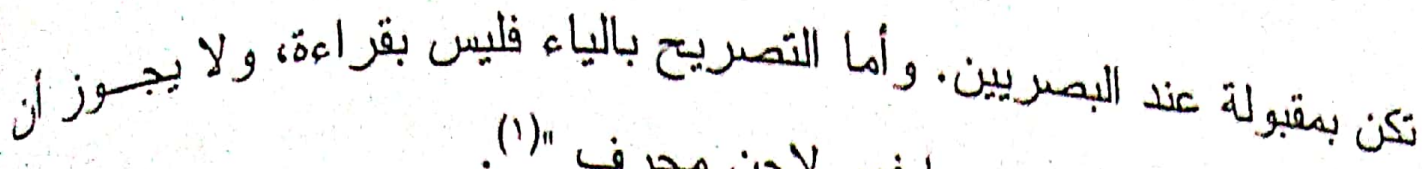

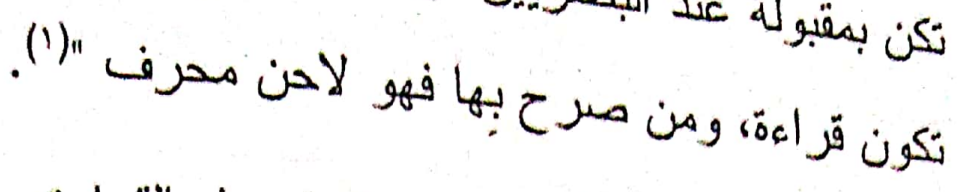
وعبارة الزمخشري تفيد قبوله هذه القراءة، و إن لم يكن في قُبوله هـان

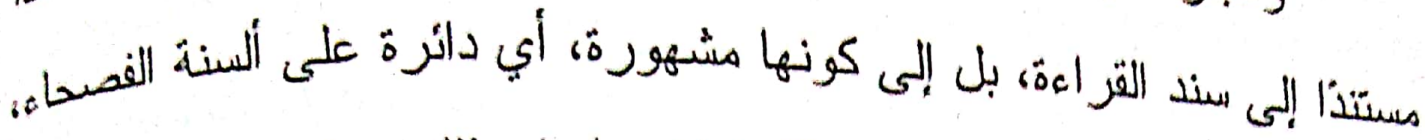

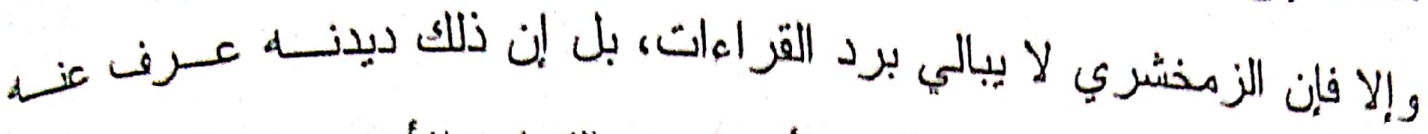
واستفاض، ولمُ نمضي بعيدًا وبين أيدينا رده القر اءة الأخرى في الكلمة نفسها،

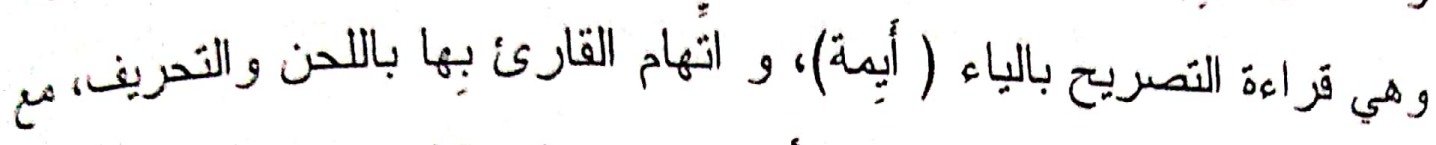
أنه قرأ بها رأس البصريين النحاة، أبو عمرو، و وابن كثير، ونافع بخلف عنسه.

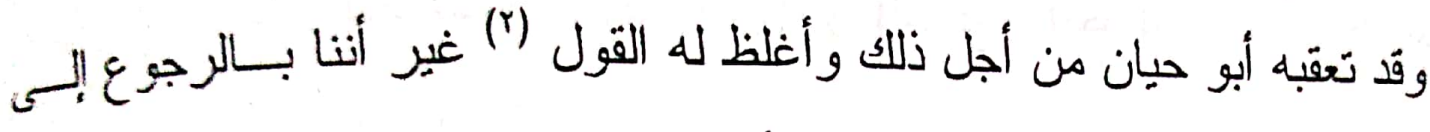
المفصل للزمخشري وجدناه يصرح بأن تحقيق الهمزتين على هذا النحو شُسـان،

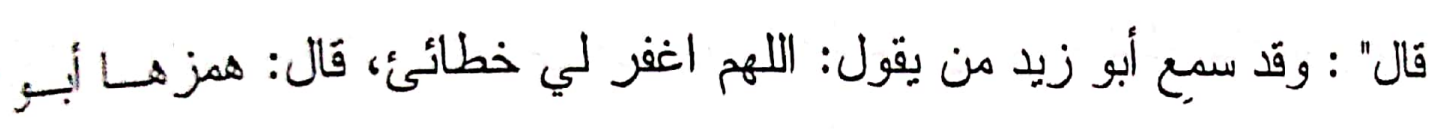
السمح ورداد ابن عمه، و هو شاذ، وفي القر اءة الكوفية أئمةًآ).

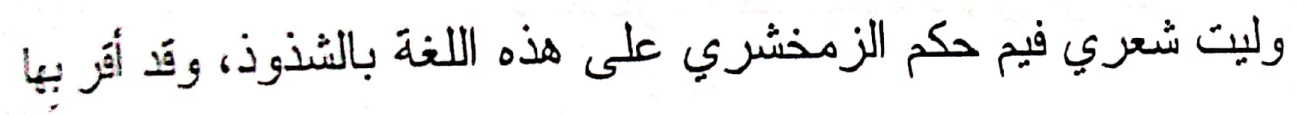

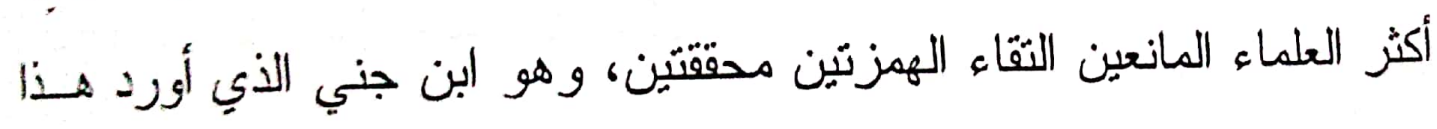
الخبر في معرض رده على من يجمع بين الهمزتين محقفتسني، فقال: "فإن فلت:

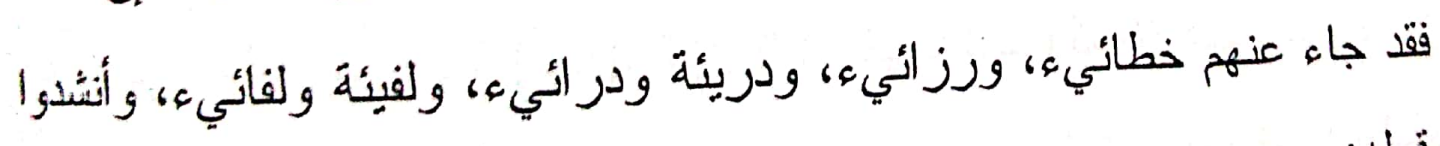

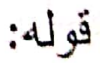

$$
\begin{aligned}
& \text { (1) (الكشاف : }
\end{aligned}
$$

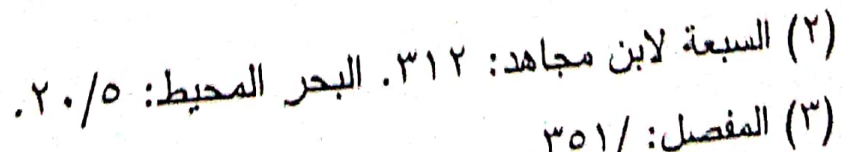

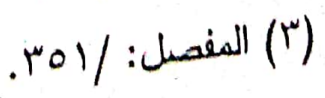




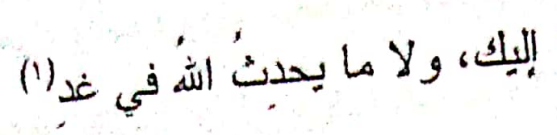

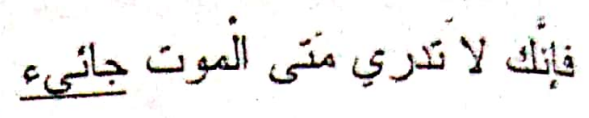

قَيل : أجل، هذا قَد جاء، لكن الهمز الذي فيه عرض عن صدة صنعة"(").

ويمضي ابن جني ليناقش كلمة (خطائيء) فيــرى أن هــزة فعائسل

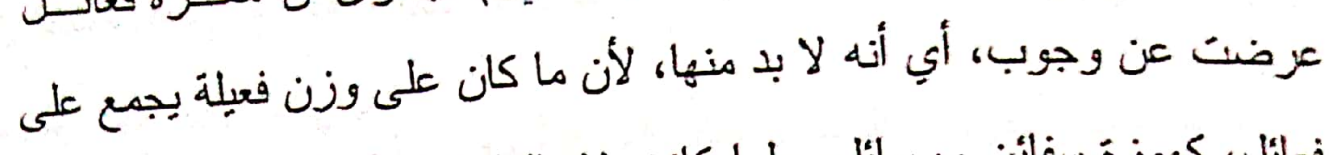

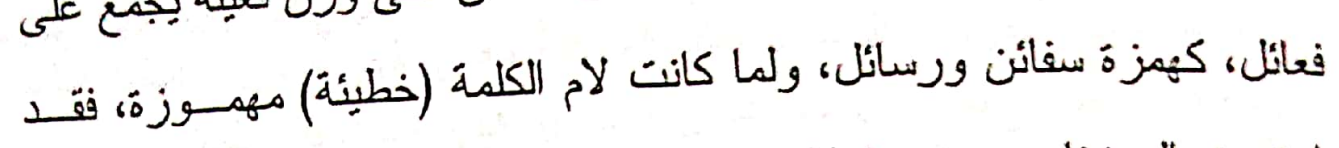

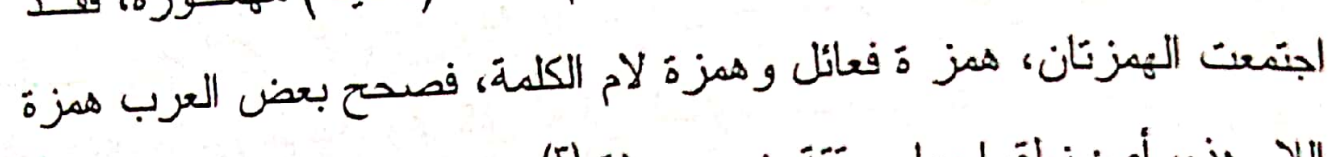

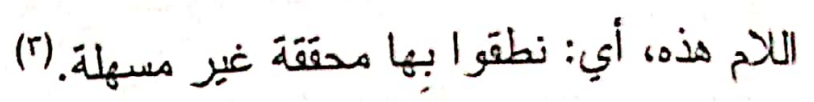

وفي احتجاج ابن أبي مريم لهذه القراءة يطالعنا قوله" : ويحسن هـــهـ

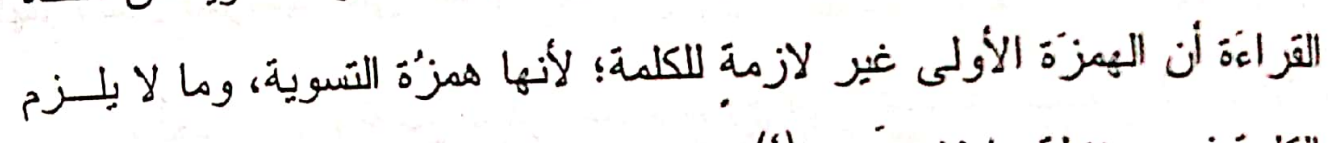

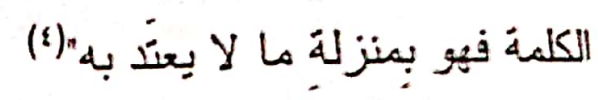

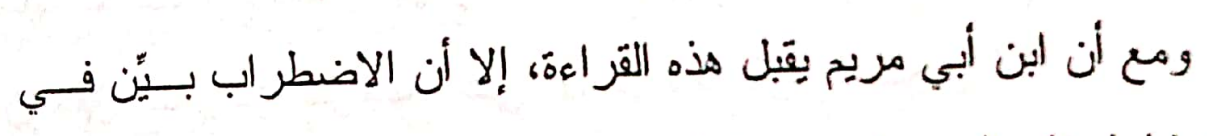

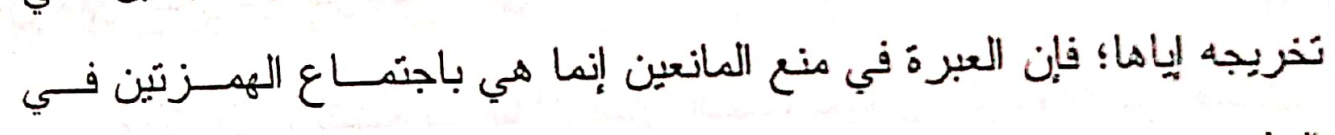

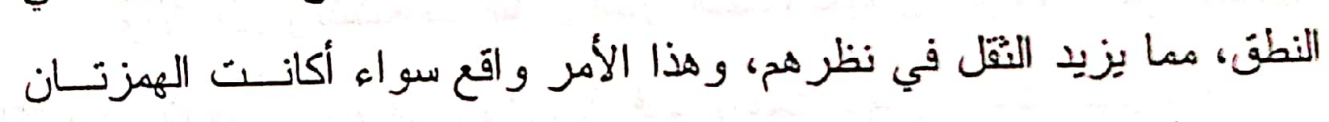

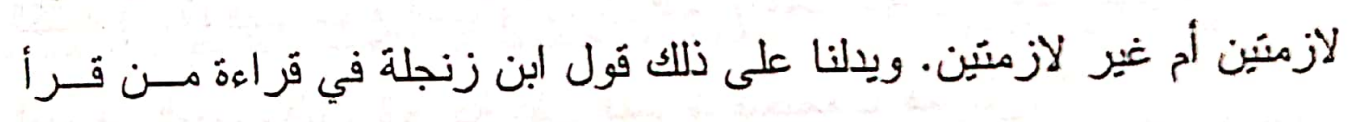

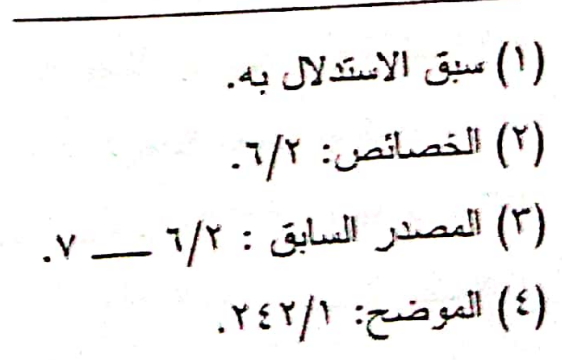

org 


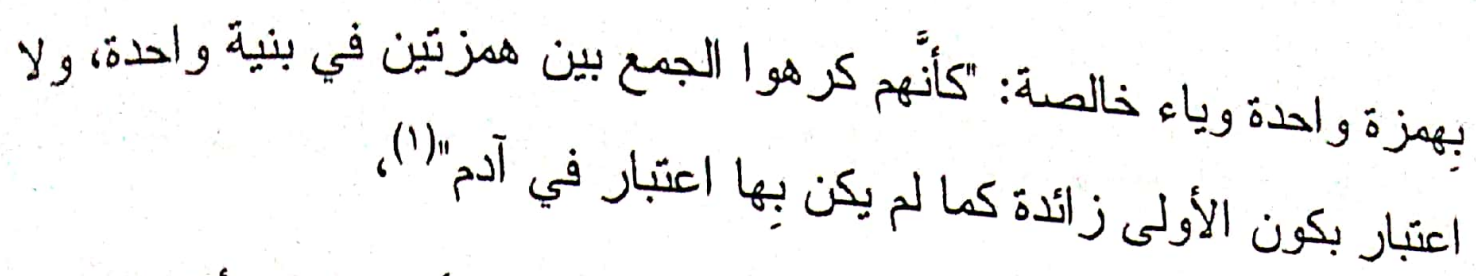

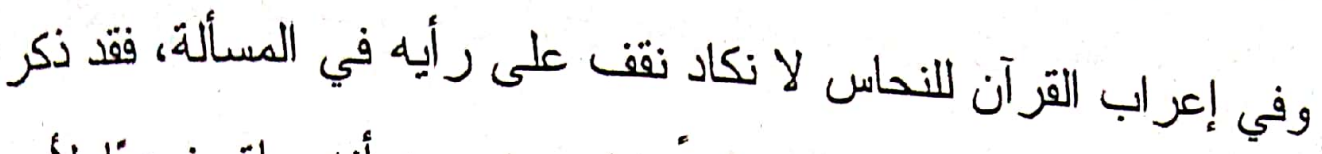

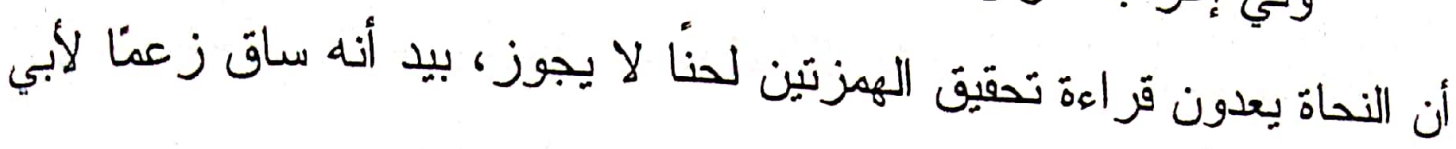
إسحاق بأنه جائز على بعد.

وإن نظرة فيما سوغ به أبو إسحاق هذا جواز اجتماع الهمزتين، لتلّل

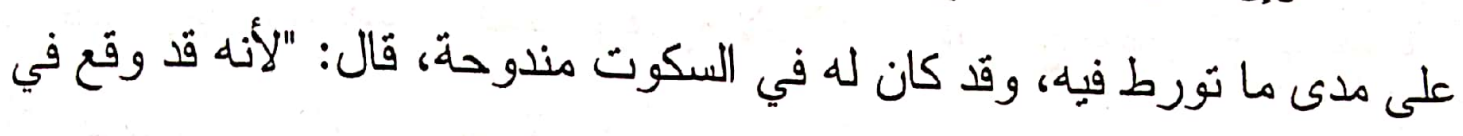

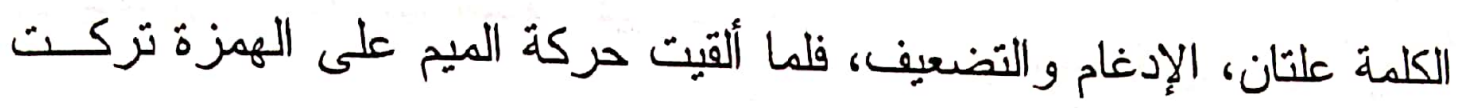

الهمزة لتنل بحركتها على ذلك."(r)

و أحسب أنه واضح ما في هذا التخريج من نكلف لا مـسوغ لــه، إلا

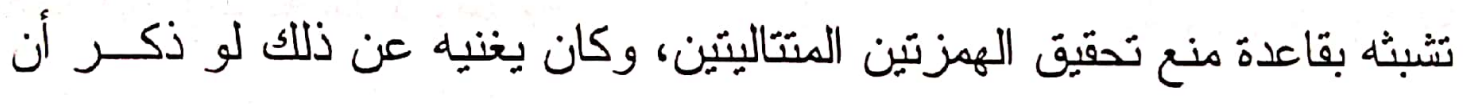

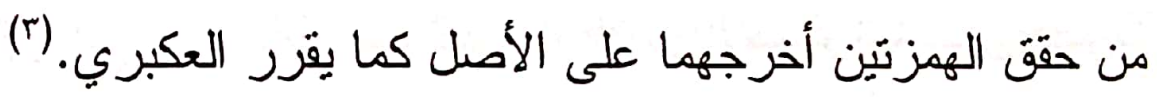

والإعلال و التضعيف اللذان أثشار إليهما، بفهمان بالرجوع إلى أصـل فيل فئل

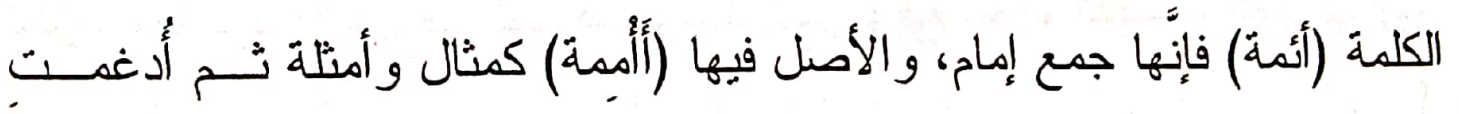

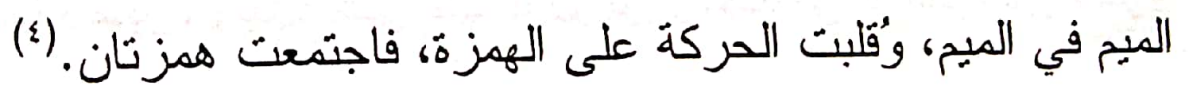

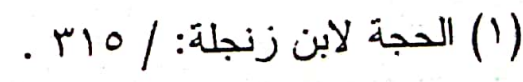

$$
\begin{aligned}
& \text { (r) إعراب القرآن للنحاس : r.o/r. } \\
& \text { (r) الثيان : r }
\end{aligned}
$$

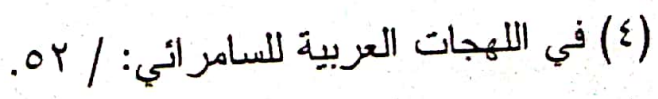




\section{المبحث الثاني}

\section{استعمالات الهمزة في الارس النحوي و الالالي}

الدلاكة الوظيفية:

الهمزة من الحروف البسيطة لفظا المركبة معنى، فهي مسـن ناحيــة البنيسة

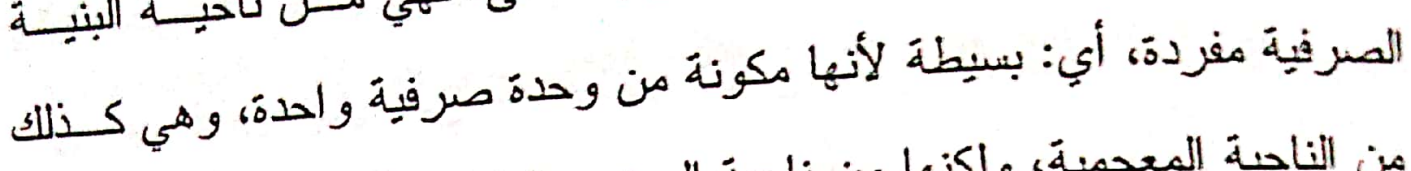

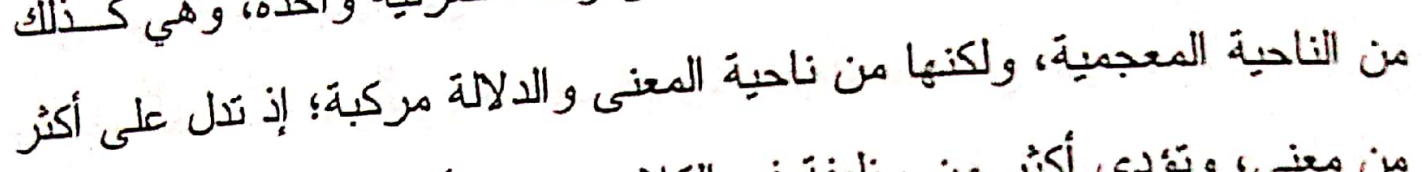

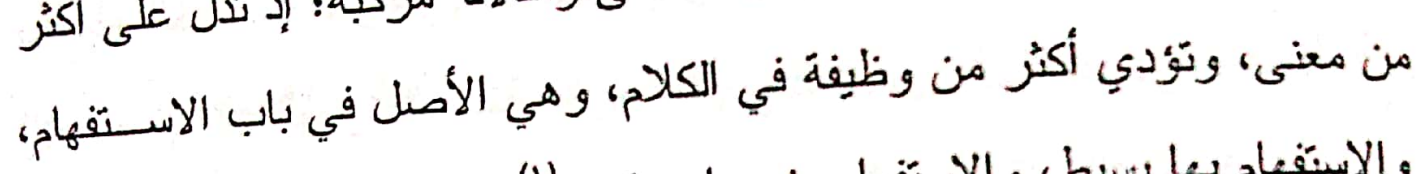

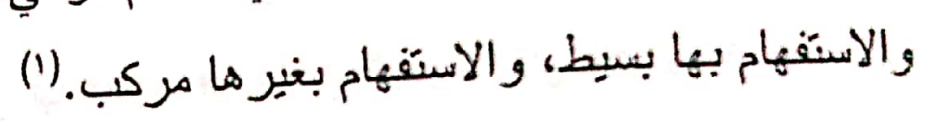

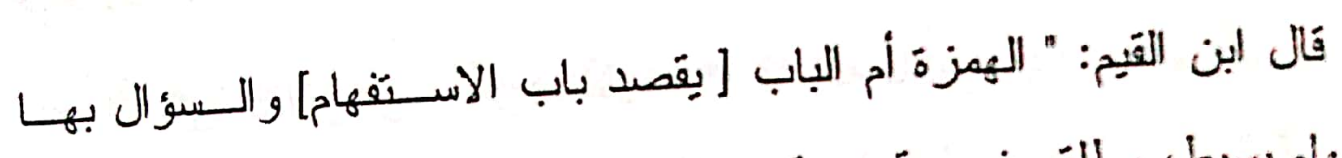

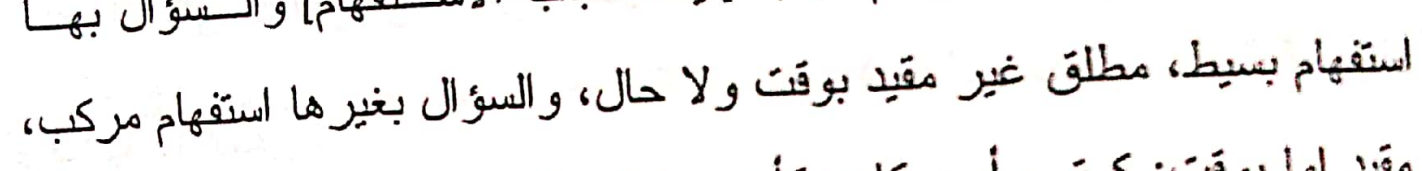

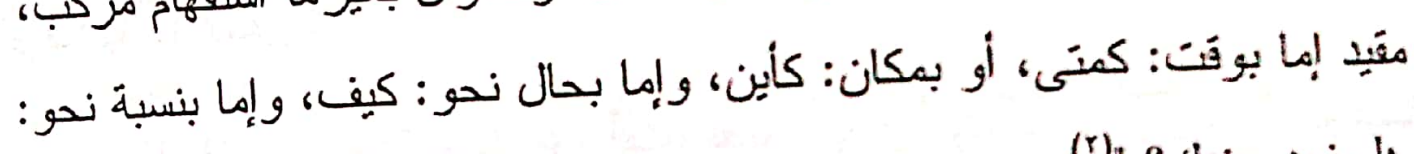

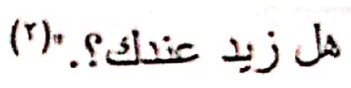

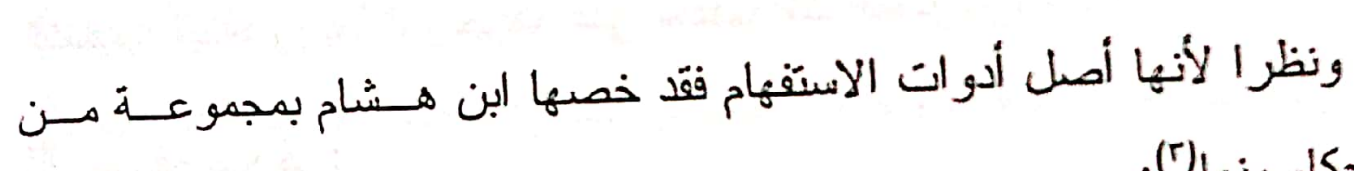

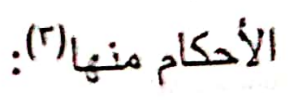

$$
\text { ا- جواز حذفها:كما في قول عمر بن أبي ربيعة: }
$$

(1) الإبساطة واللتزكيب في النحو العربي، للدكتّر ائر اهيم محمد خفاجة، رسالة دكتور اه، كلية

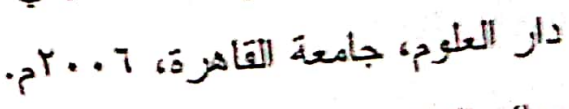

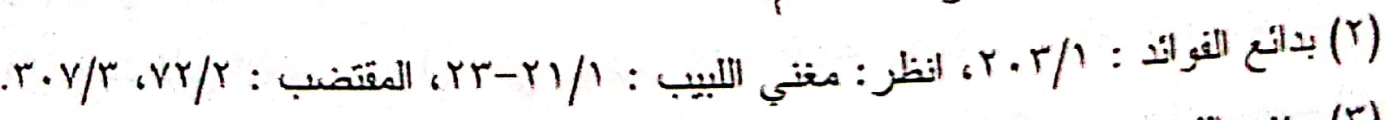
r r r r 


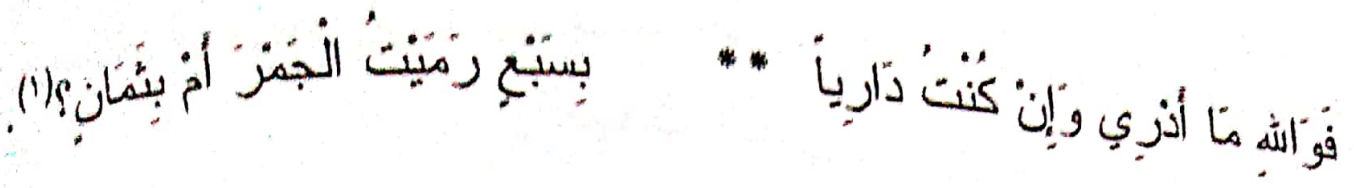

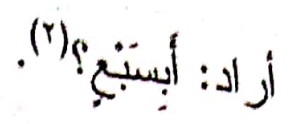

وذكر ابن جني مو اضع حذف الهمزة فقال: "من ذلك قولنا: الله، وأضلك.

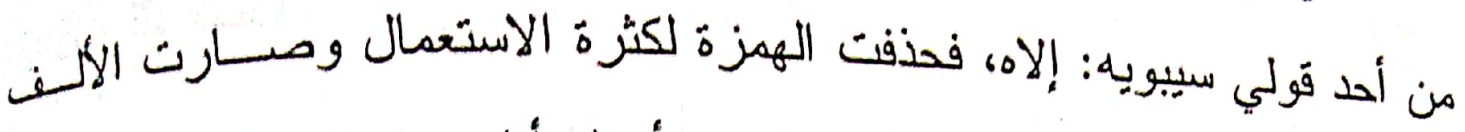

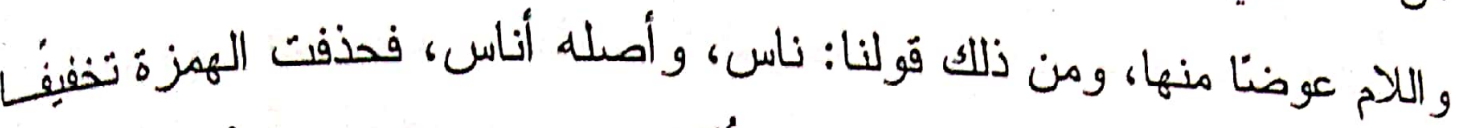
على غير قياس، يدل على ذلك قولهم: الُأناس؛ وعن ذلك قولنا خذ، وكلن، ومز،

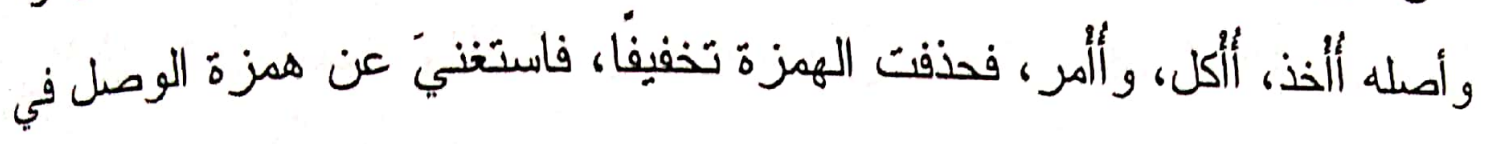

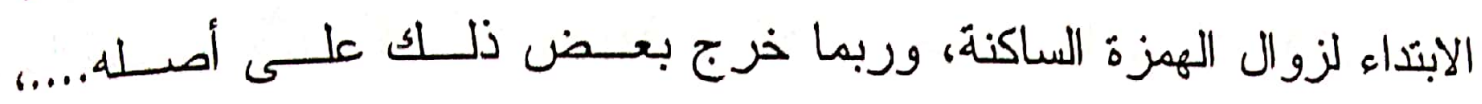
ويقولون: يا باً فلان، بريدون أبا فلان، فيحذفون الهمزة، قال الشاعر : يبا المغيرة رب أمبر معطل ** فرجته بالنكر منِّي و الدها(ت)

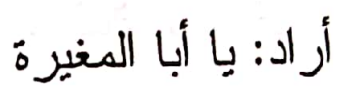

وحذفوها أيضًا من مضارع رأيت، فقالوا: يرى، وتزى، ونرى، فألزموهـا

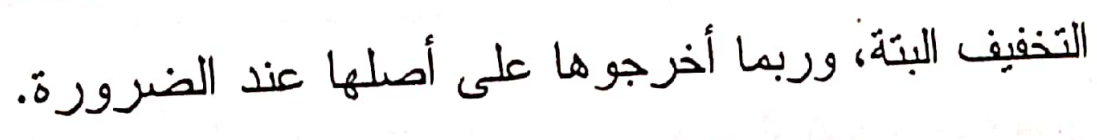

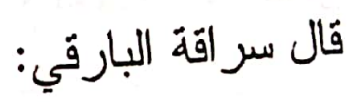

أرى عيني ما لم ترأياه :* * : كلانا عالم بالتز هات

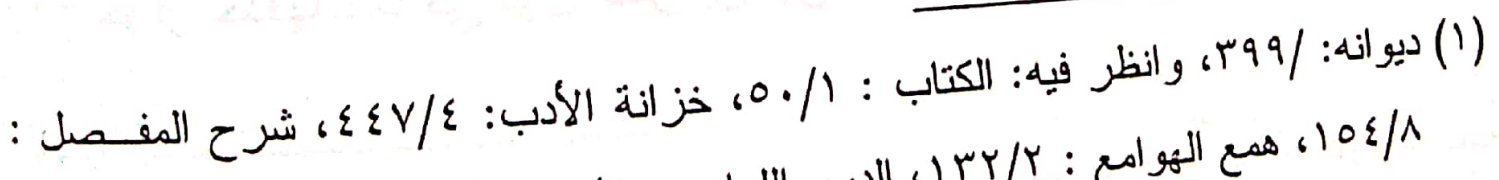

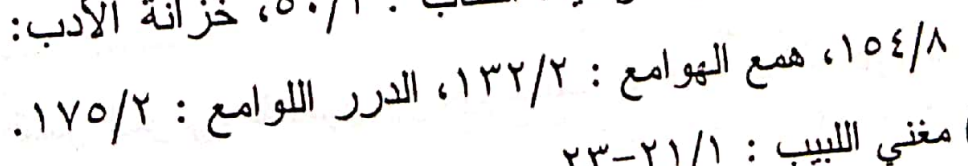

$$
\begin{aligned}
& \text { (") البيت لأبي الأسود، ولم أجده في ديوانه. }
\end{aligned}
$$




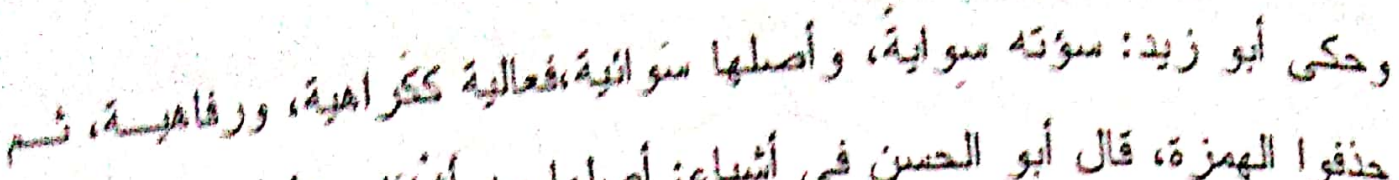

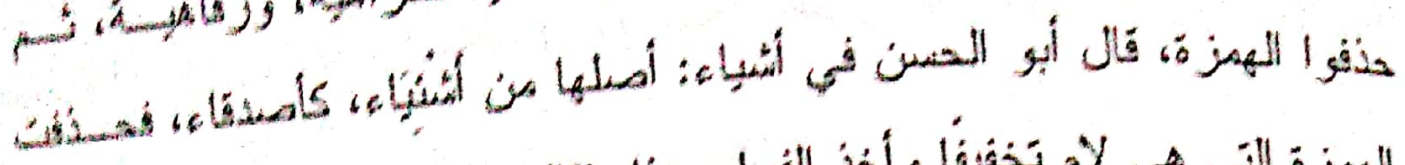

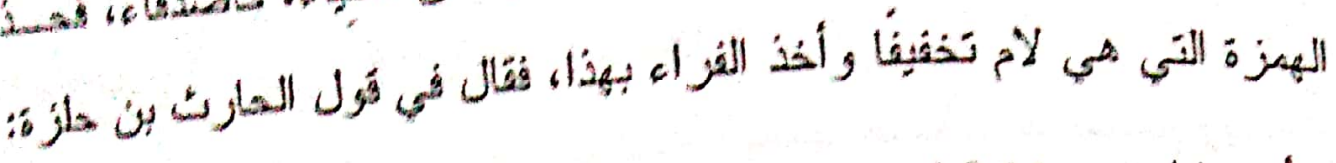
(9)

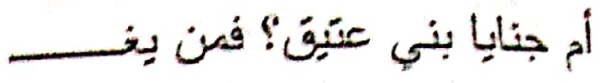

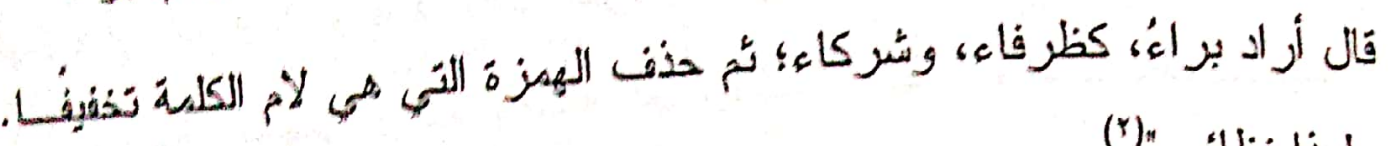
ولهذا نظائز." (") ץ-أنها تزد لطلب النصور : نحو: أزيد قائم أم عدرو ؟ ولطلب النصديق ندو: أزيد قائم؟.

ب-أنها تذخل على الإثبات: ندو: أزيد عندك؟، وتذخل على النفي ندو قولـهـ

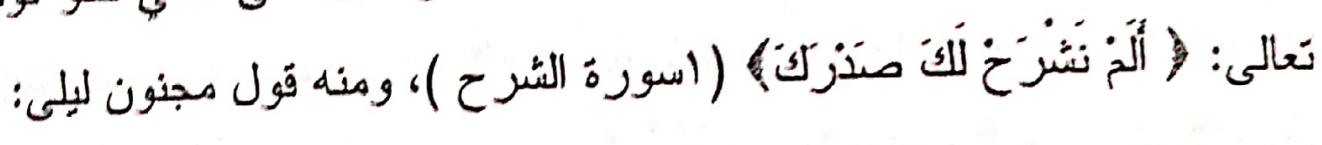

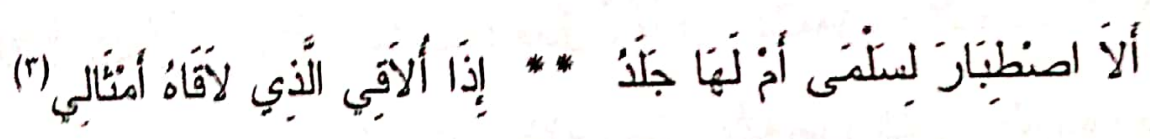
و النُاهد فيه دخول همزة الاستفهام على لا النافية، وزو ال معنى الاســفهام

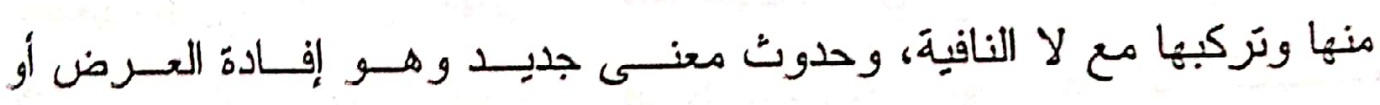
التحضيض.

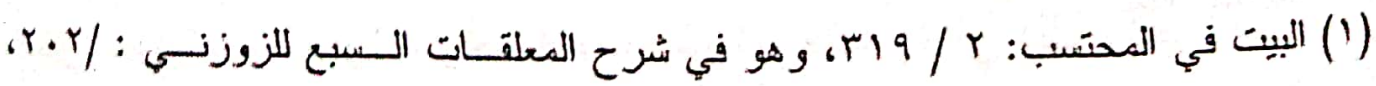
وروايته فيه :

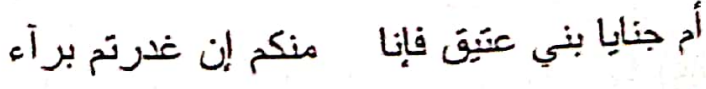

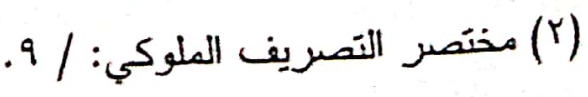

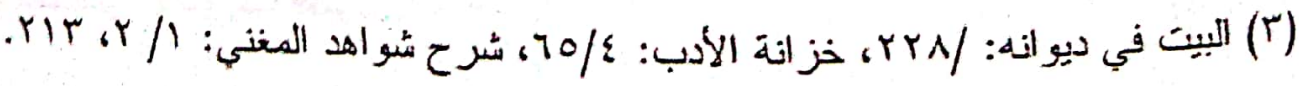




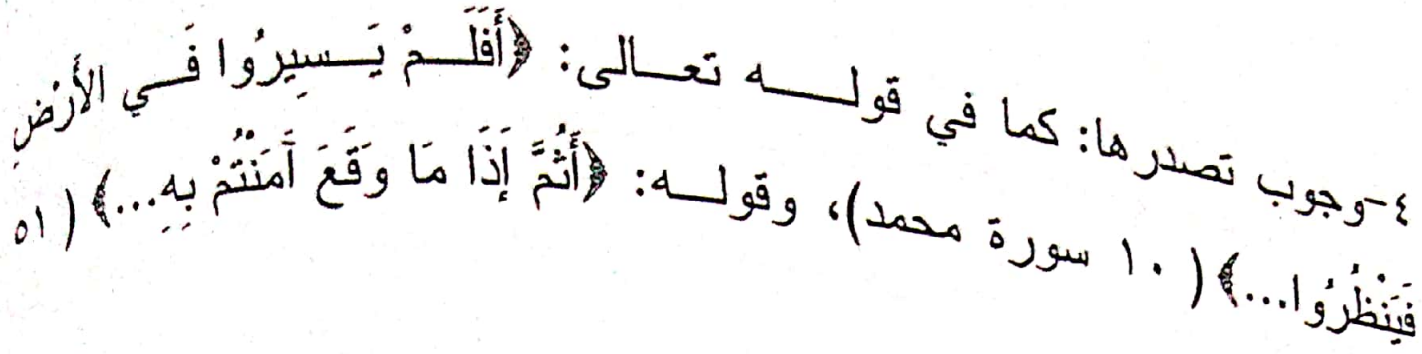
سورة يونس).

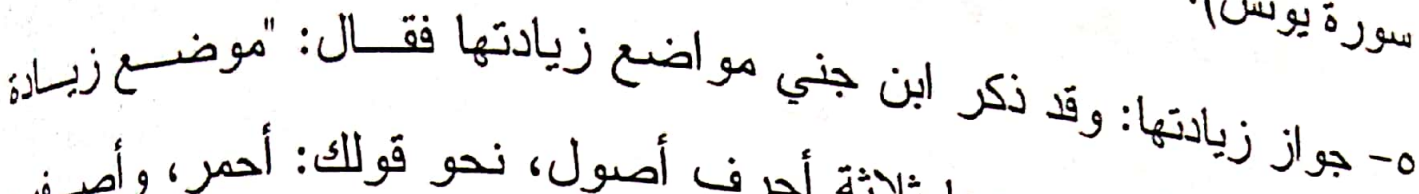

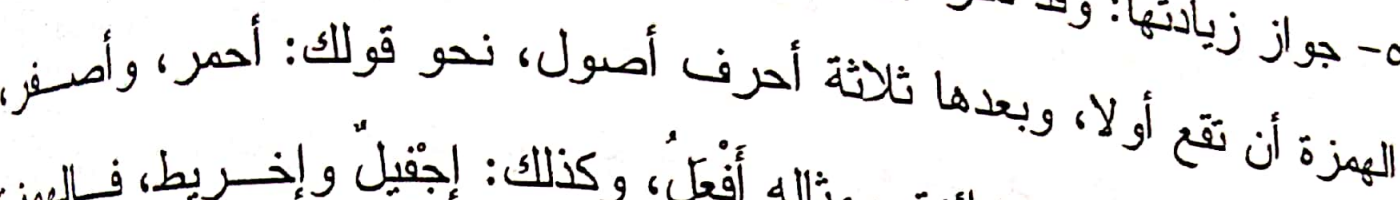

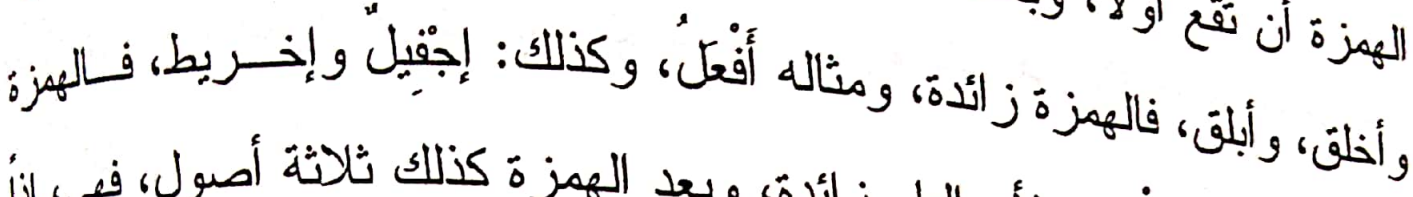

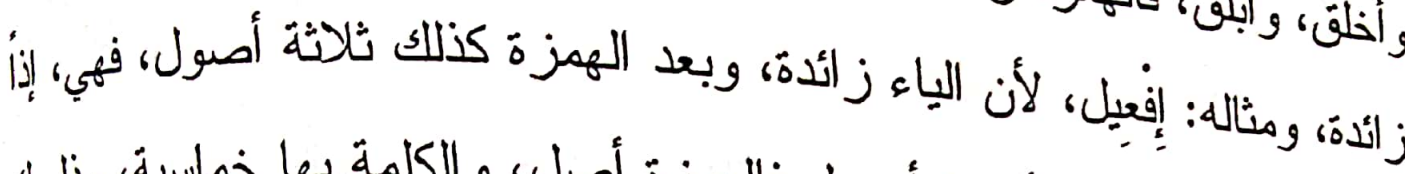

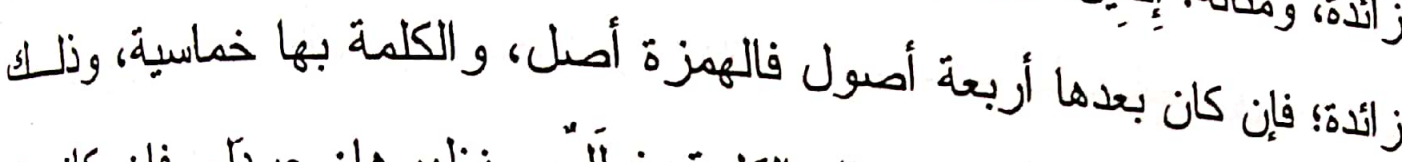

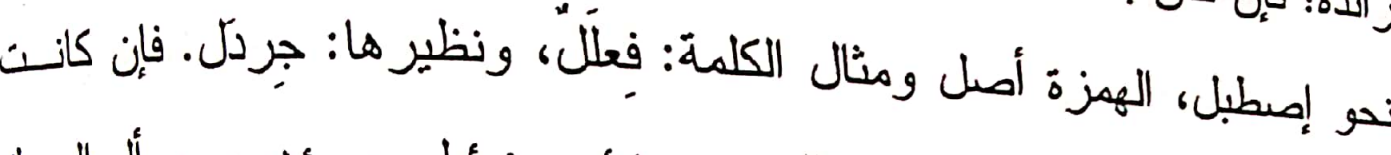

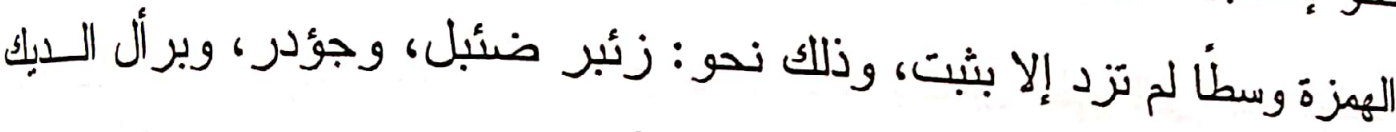

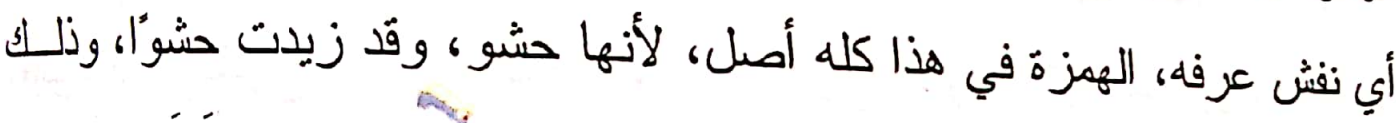

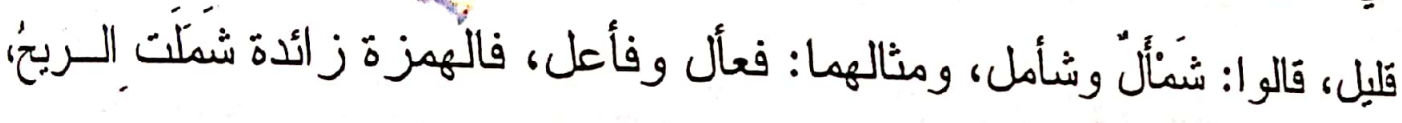
والهمزة أيضا في جرائض زائدة، ومثاله فُعِئل لأنه من الشيء المحطوط، وهله

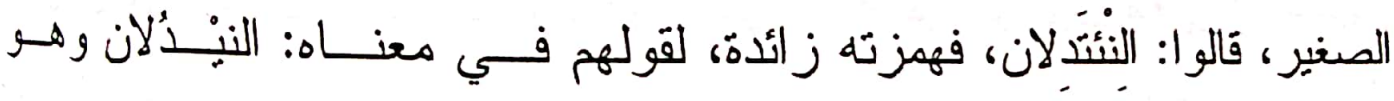

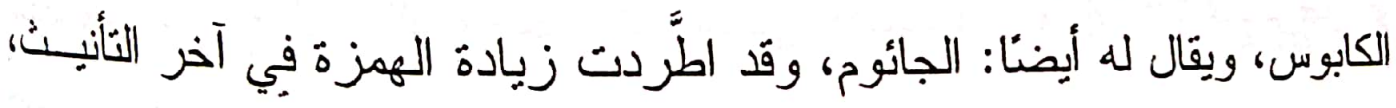

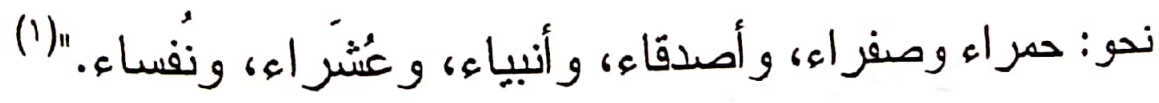
1- جواز إيدالها: فقد ذكر ابن جني أن الهمزة قد أبدلت من الألف للتأنبث، في

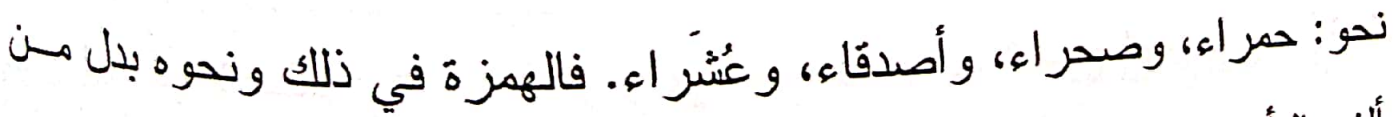

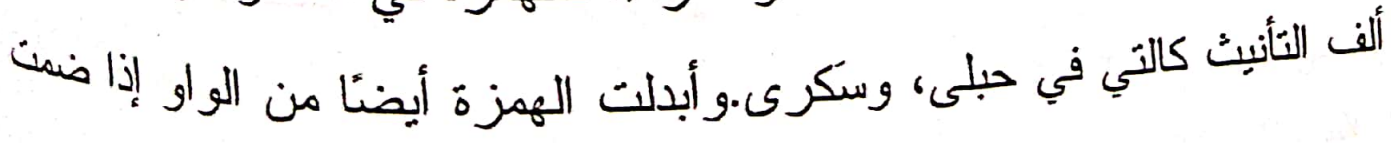

(1) مختصر النصريف العلوكي: / ع. 


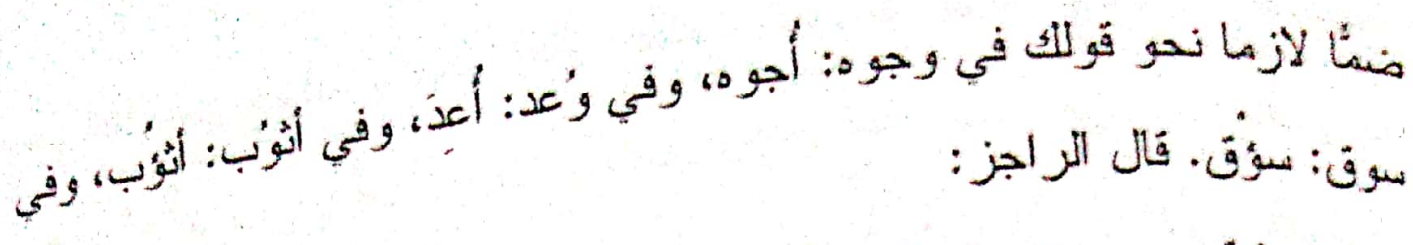

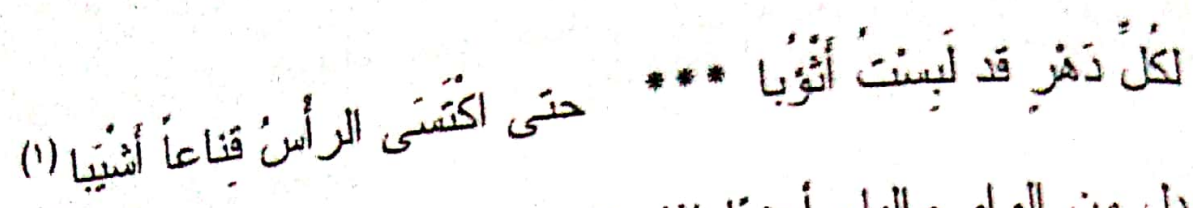

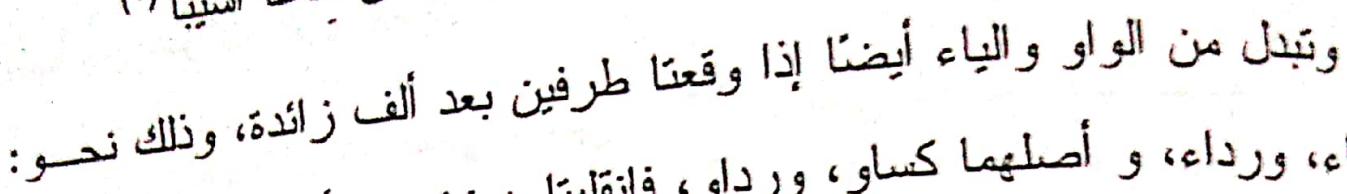

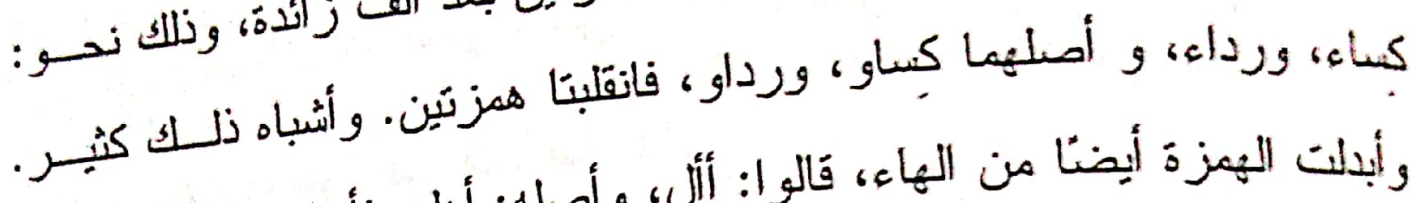

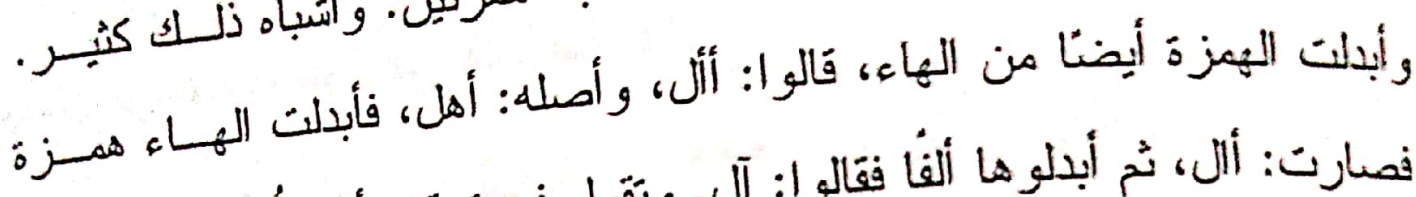

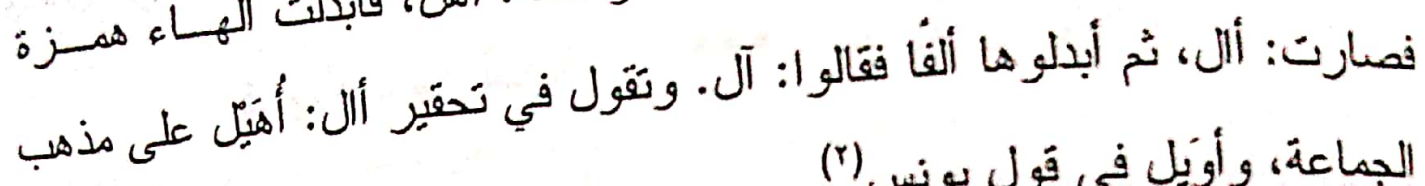
الجماعة، وأويَل في قُول يونس (r) كما أبدلت الهمزة هاء؛ تقول العرب: أرَتَتُ، وهرَتَ، وفي أنسرت الثــوب:

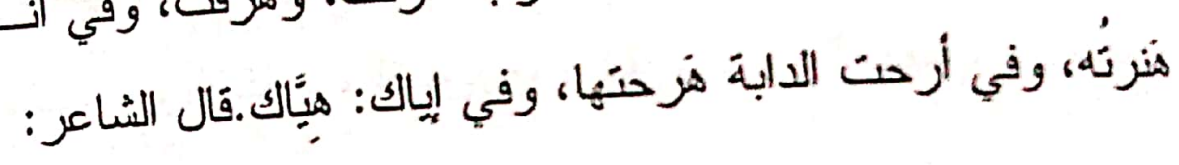

مو ارده ضاقتت عليك مصادره (r)

* ثيّاك والأمر الذي إن نوسعت ومن الو او في قَول امرى القيس:

ه، وبحك! ألحقت شرأ بشر (ई)

** وقَ رايني قولها: بيا هنا

(1) البيت لمعروف بن عبد الزحمن في لسان العرب، مادة (ث وب)، المخصص: ب/؟ وب. (r)

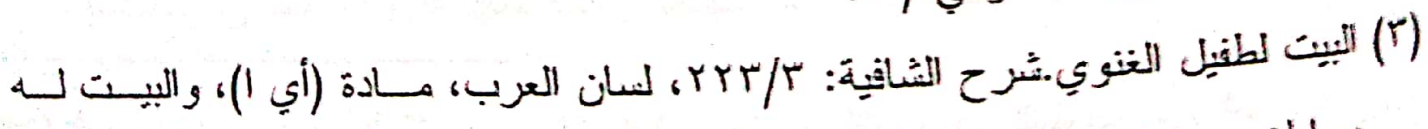
روايلت مختلقة.

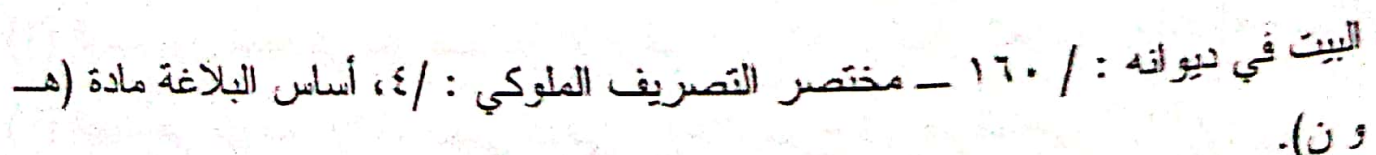




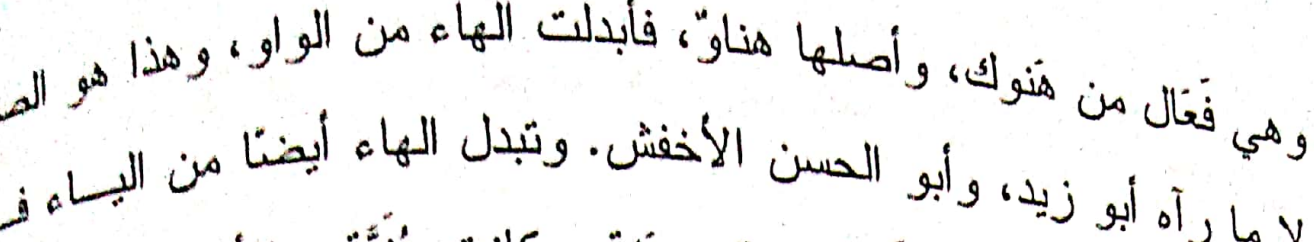

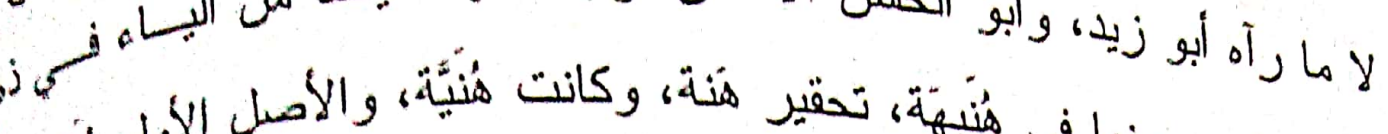

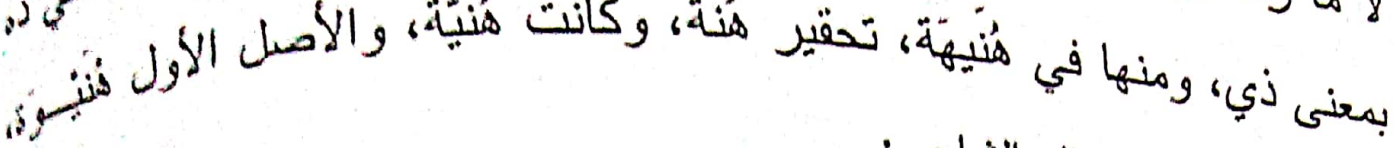

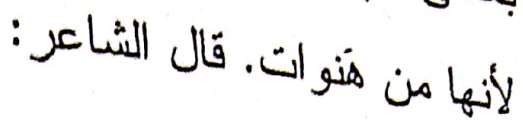

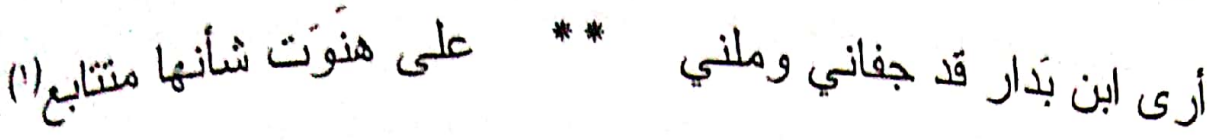
وتبدل من الألف، تقول في هُنا: هنَة. قال:

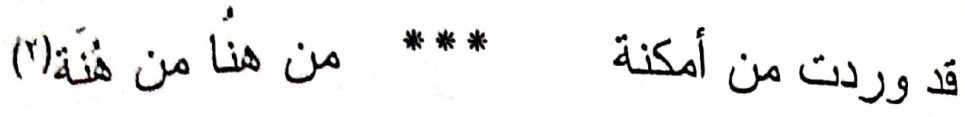
والهمزة إذا كانت مفردة، أي: بسيطة غير مركبة مع غبرها فإنهانسل على معان كثيرة منها الاستقهام، وهو الأصل فيها، وتخرج عن معنى الأشتهار

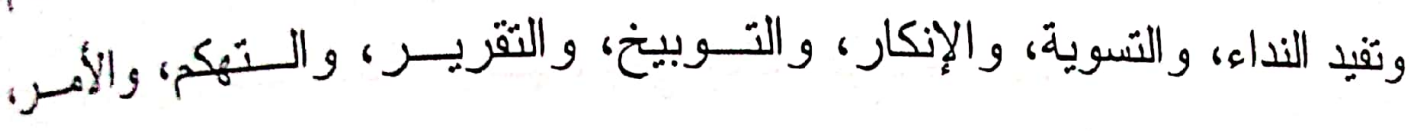
و التعجب، والاستبطاء.

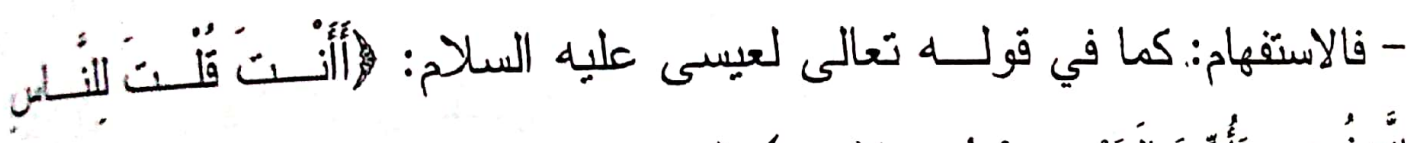

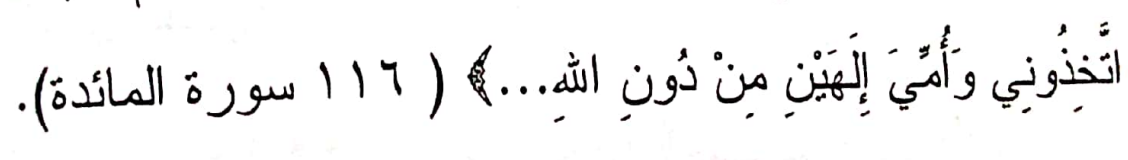
و والنداء: كما في قول امرئ القيس:

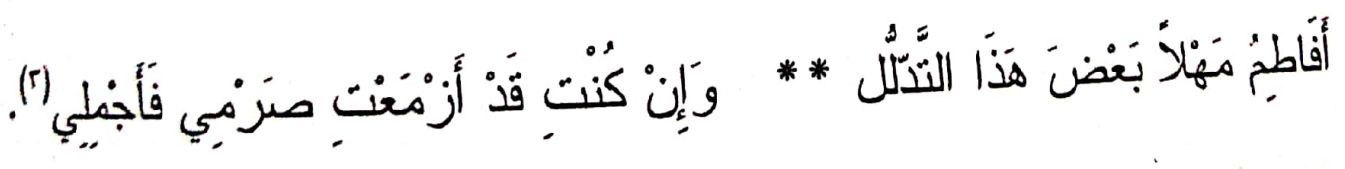

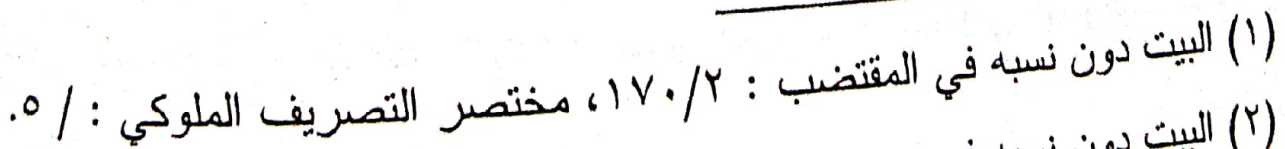

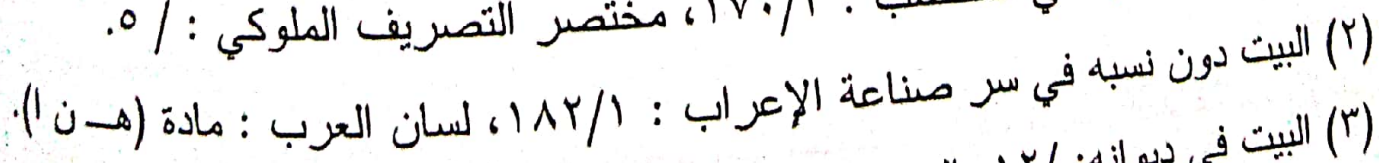

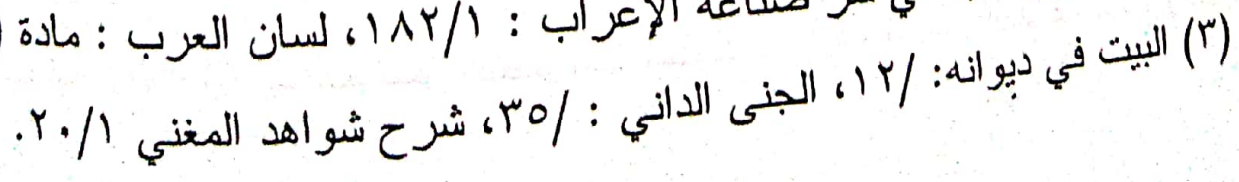




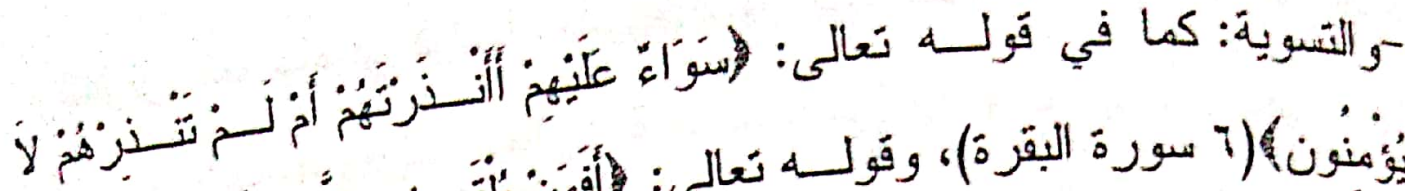

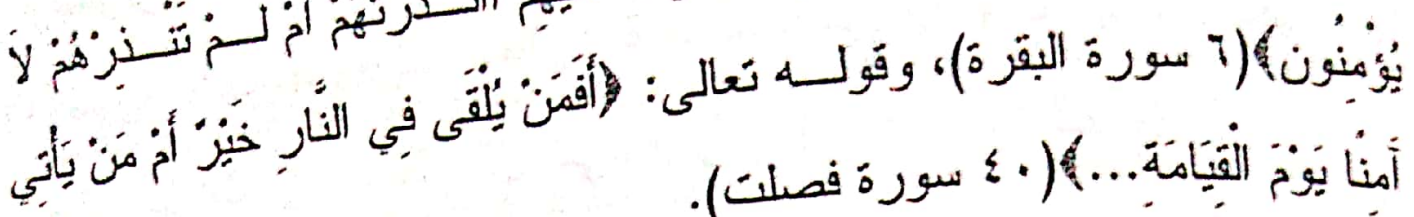

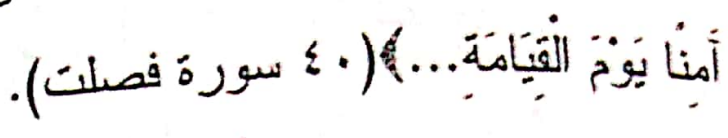

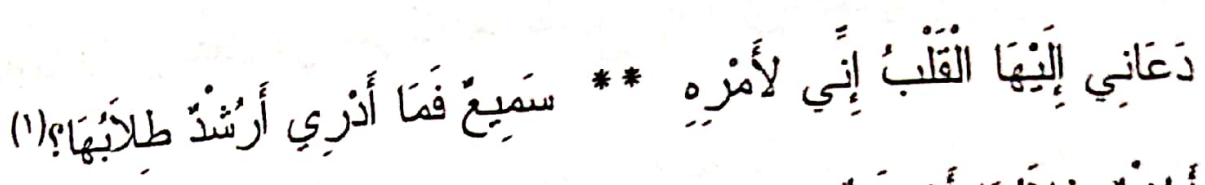

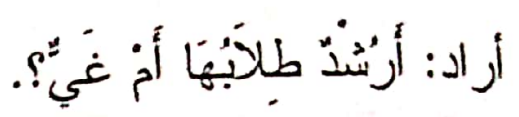

- والإنكار الإبطالي: وهو الذي يفِيد أن ما بعده غير واقع، نحو ما جـاء فــي

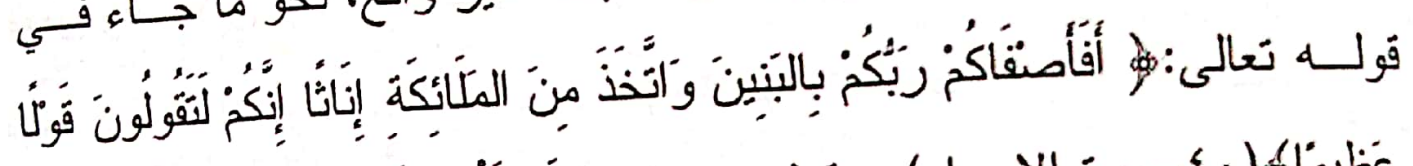

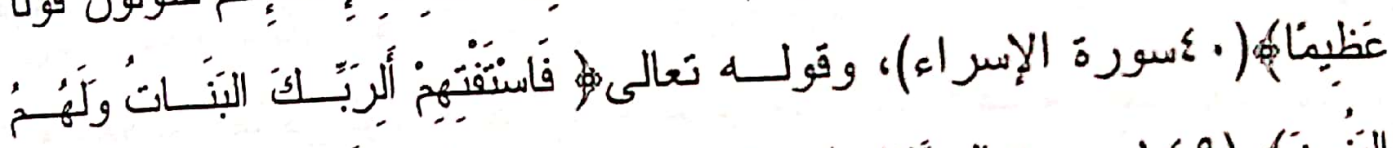

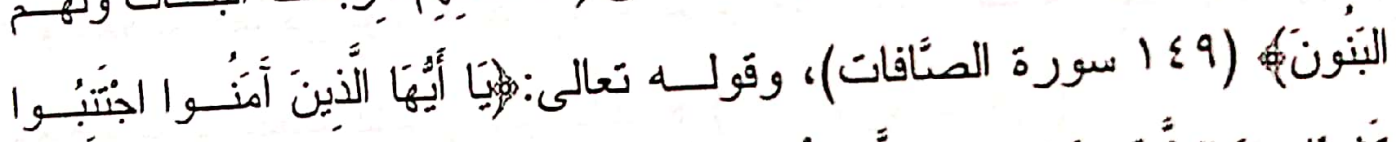

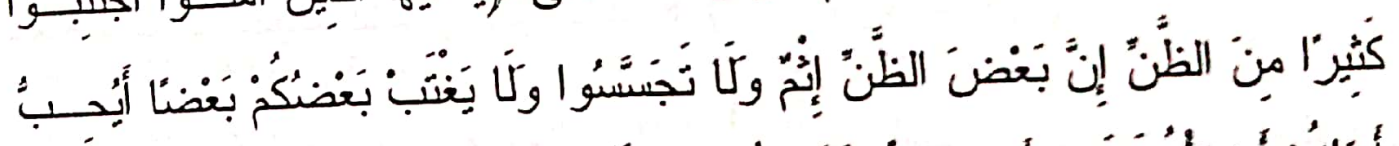

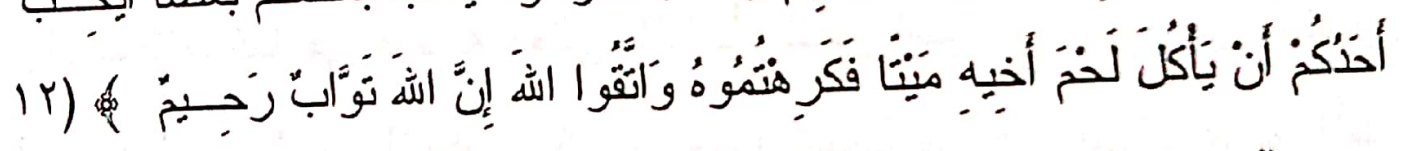

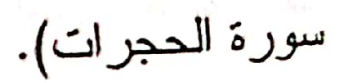

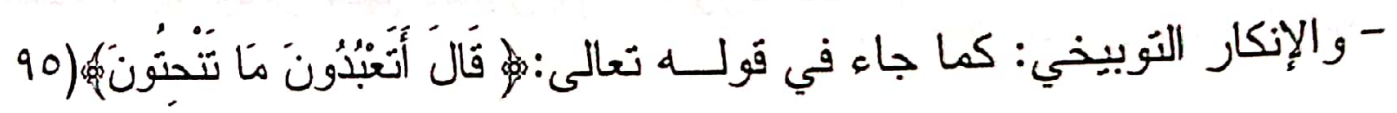

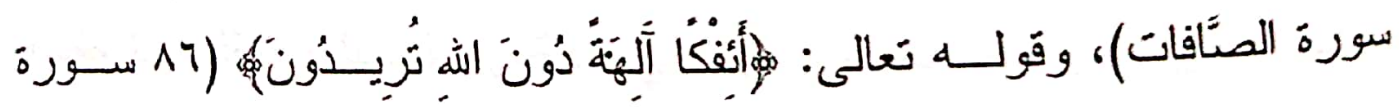

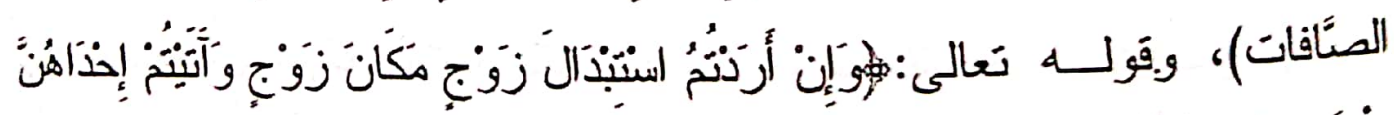

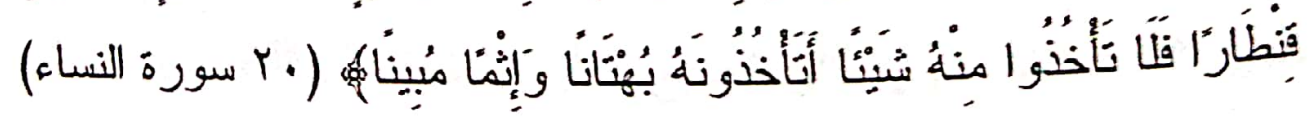

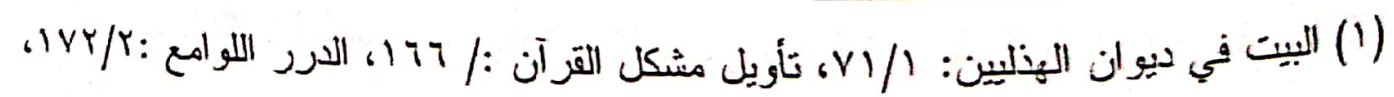

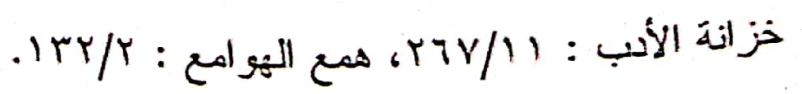




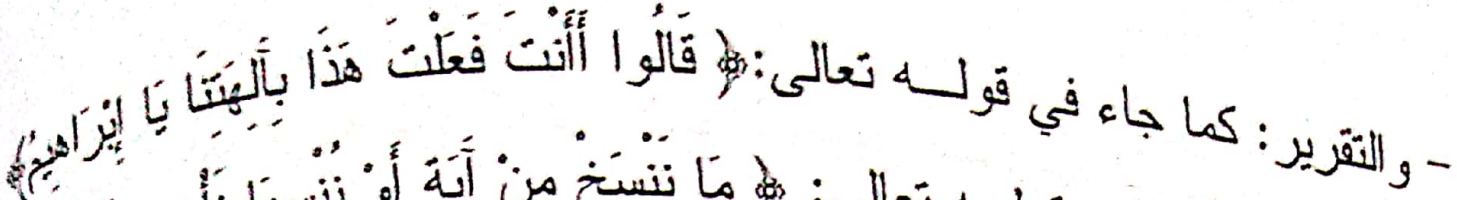

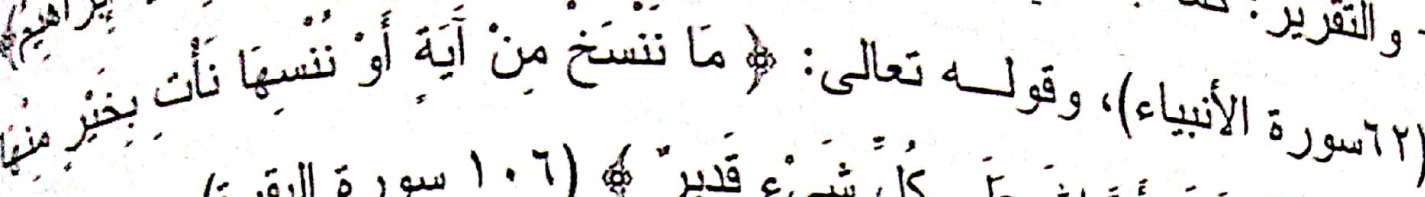

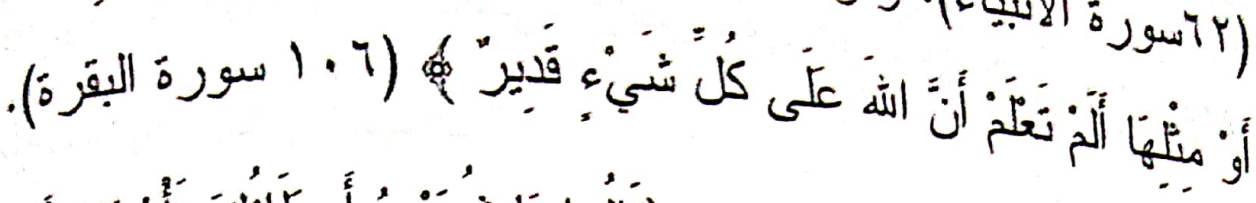

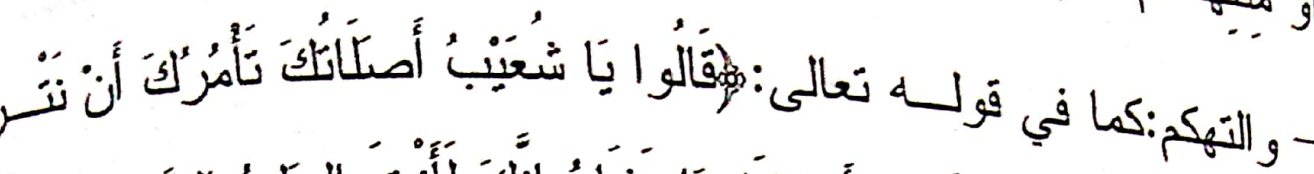

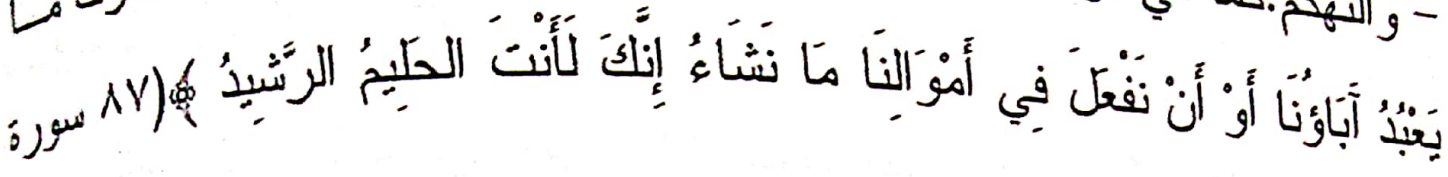
هو د).

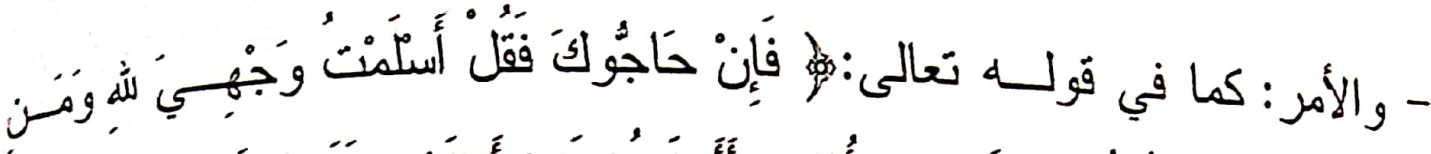

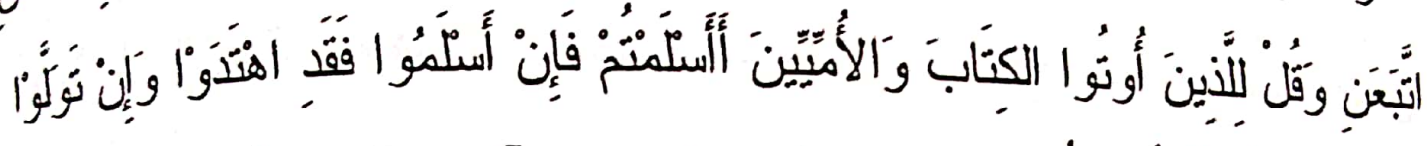

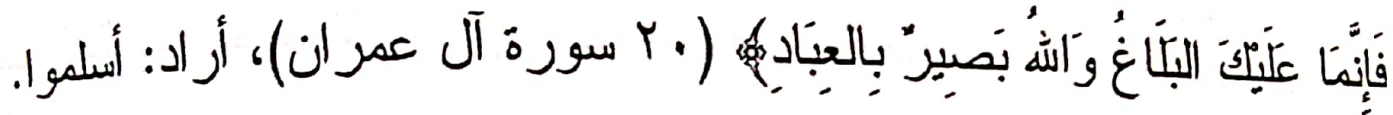

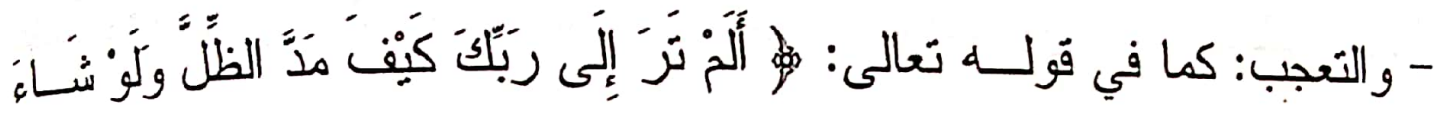

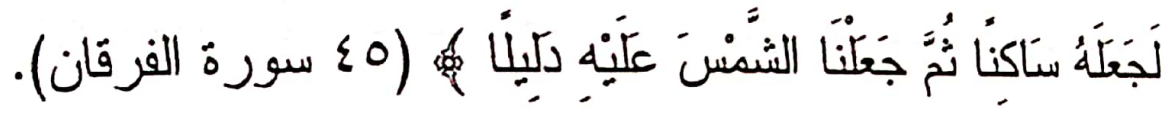

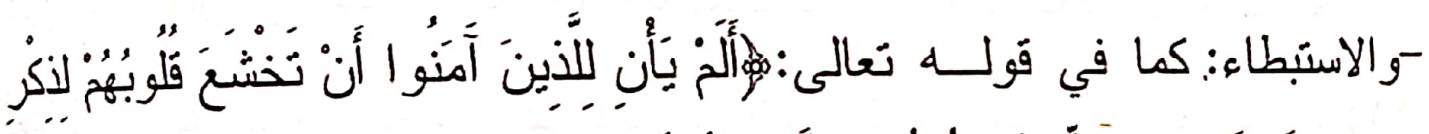

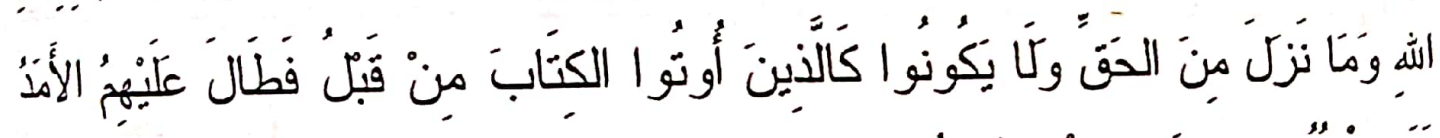

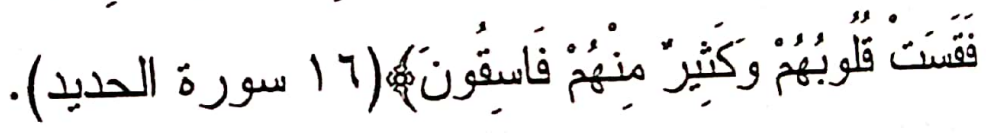




\section{نتائج البحش}

لقد حاولت خلال هذا البحث الغوص في بطون المزات اللغوي؛ للكئف

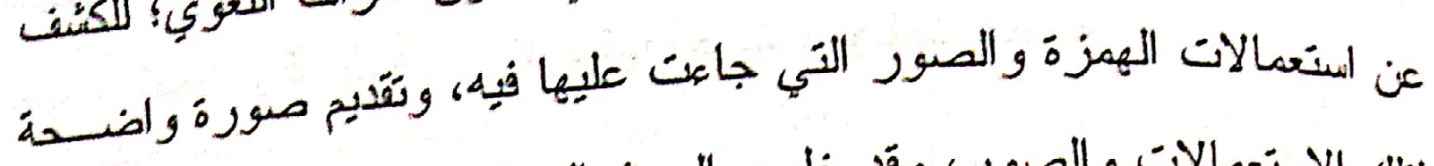

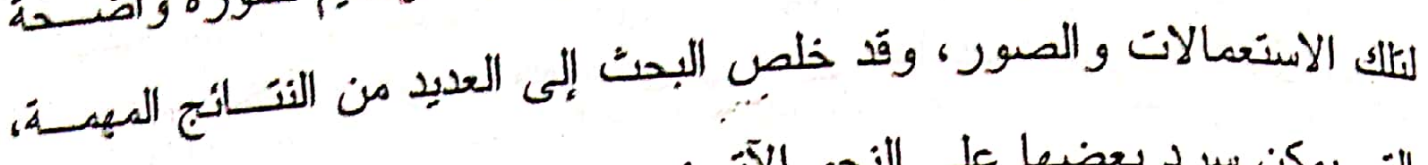

$$
\text { التي يمكن سرد بعضها على النحو الآتي: }
$$

أو لا: رصد البحث الار اسات الخاصة بالهززة، و التي تتاولت أحكامها وأحو الها، وناقَّ نتائجها وستفاد في استُّمار الكثِر منها في هذا.

ثانيا: تتبع البحث اختلاف مذاهب العرب في النطق بهذا الحرف، فتز اوحت بين النحقِقَ، و التسهيل، وكان لكل منهم طربقته في استعمال هذا الحرف، مفردا كان

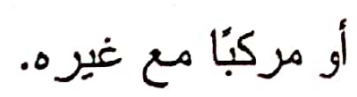

ثالثا: تسهيل الهمزة كان منسقاً مع طبيعة العرب ورغبتهم في التخفيـف، وبـهـ ورد الاستعمال القز آني.

رابعا: تسهيل الهمزة بالإبدال أو الحذف كان أحد مظاهر التخفيف الذي جنح إليه الاستعمال اللغوي عند عامة العرب.

خامسا: بعض العرب قَّ خالفت مذهبها في التحقيق و التسهيل، فحققت ما حقـهـ التسهيل، وسهُت ما حقه التحقِيق، وبناء على ذلك اختف القراء و النحويون في تقسبر تلك المذاهب، و إن كان الجميع قَ أورد الاستحمال اللنوي به. سادسا: بِكن، من خلص التبّع التاريخي للصيخ اللغوية التي وردت في احتجاج كلا الفريقين، دراسة النطور التاريخي و الدلالي لكثير من مفردات اللخة. 


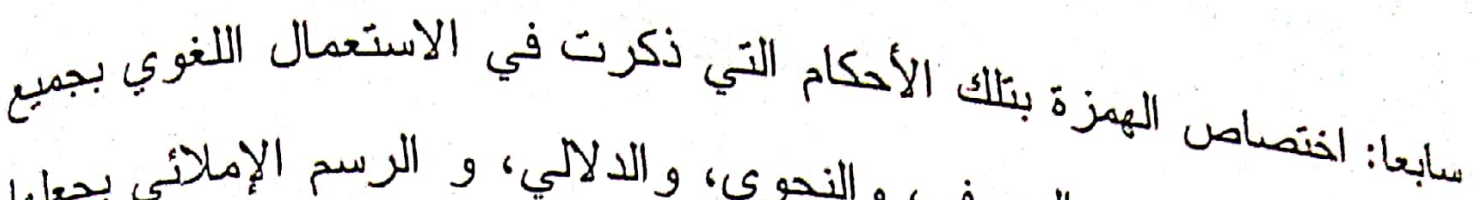
مستوياته، الصوتي، و الصرفي، و النحوي، و الدلالي، و الرسم الإملائي بجعلها

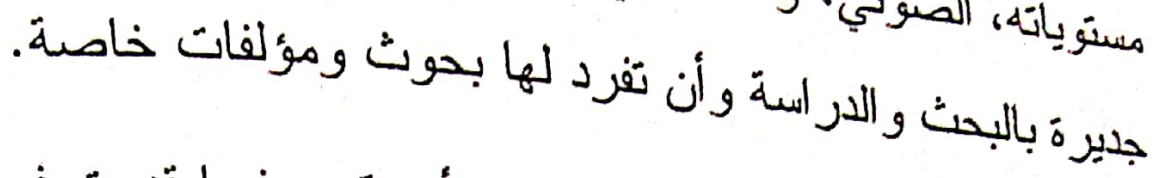
وفي الختام أرجو من الش تعالى أن يكون فيما قدمت في هذا العمل النفع

و الفائدة. 
مصادر البحث

أولا: الكتب المطبوعة:

- الإبانة عن معاني القز اءات، مكي بن أبي طالب الأنصاري، تحقيق محبي اللدين رمضان، دار المأمون للتزات، دمشق -بيروت، الطبعة الأولى، .p) 9va

-الإبدال، لابن السكيت، تحقَيق : د. حسين شرف، الهيئة العامة للُؤون المطابع

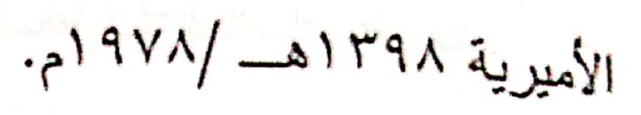
- إيدال الحروف في اللهجات العربية، سلمان بن سالم السحيمي، مكتبة الغرباء الإنسلامية، المدينة النبوية، الطبعة الأولى،990ام. - إبراز المعاني من حرز الأماني،لأبي شامة، مطبعة الحلبي، مصر، . $\rightarrow 15$ ?

- إتحاف فضلاء البشر في القراءات الأربع عشر، اللشيخ أحمد الامياطي، طبع عبد الحميد حنفي.

- أنز القز اءات في الأصوات والنحو العربي، عبد الصبور شاهين، مكتبة الخانجي، القاهرة، الطبعة الأولى، 9AV ام. -الأزمنة والأمكنة، للمرزوقي، حيلر أباد، هاباهــ -أسنس البلاغة، الزمخشري، دار الكتب، צو9 ام. 


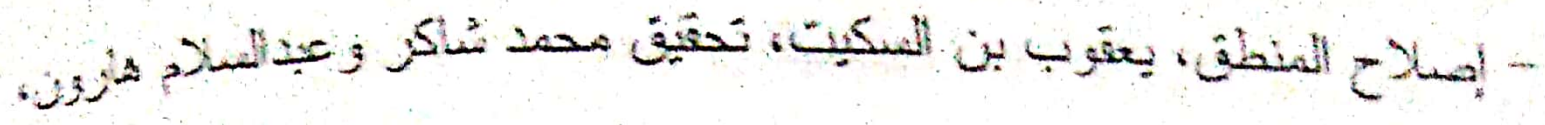

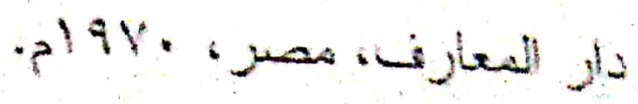

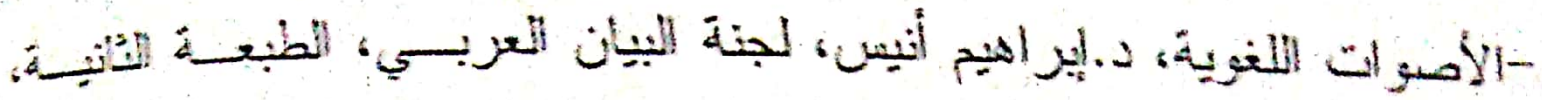
.0190.

- إعزاب القرآن، أبو جعفر النحاس، تحقيق: زهيز غـازي زاهـد، مطبهة

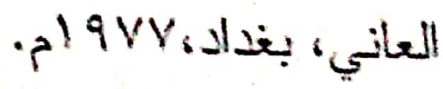

-الاقتر اح في علم النحو، اللسيوطي، دائرة المعارف العثُانيـة، حيـدر أبــاد،

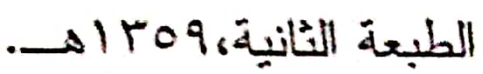

- الأمالي الشجرية، هبة الله بن علي بن مجد اللين بن حمزة الحسني العلوي، تحقيق: محمود محمد الطناحي، مكثبة الخانجي، القاهرة.

- الإنصاف في منائل الخلاف بين النحويين البصريين و الكوفيين، أبو البركات

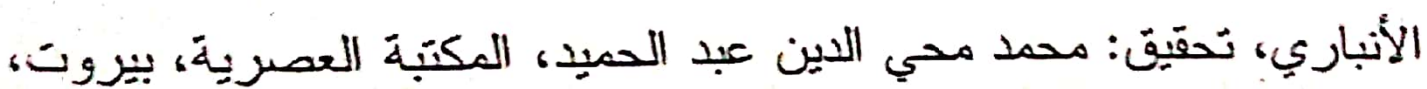

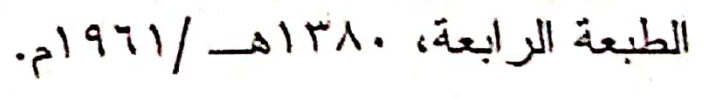

-البار ع في اللغة، لأبي علي القالي، تحقيقَ :هانشم الطعان بدار النفائس،

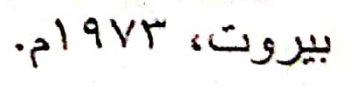

- بدائع الفو ائد، ابن قَيم الجوزية، دار الكتاب العربي، بيروت. - البحر المحيط، أبو حيان الأندلسي، تحقِقِ عبد الرزاق المهدي، دار إخياء

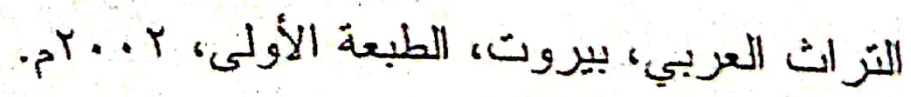




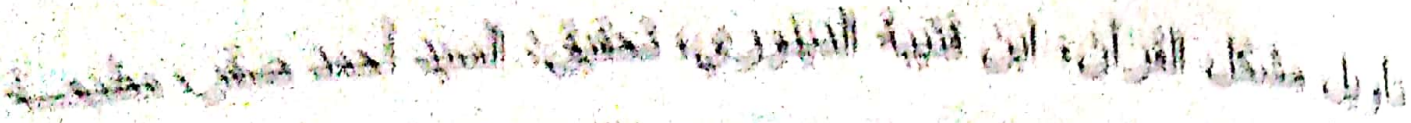

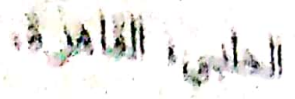

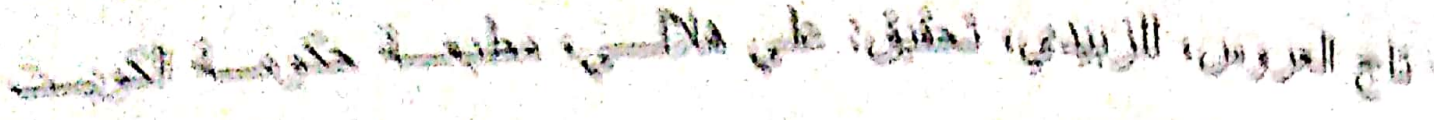

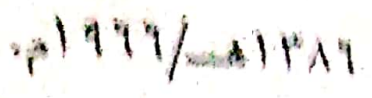

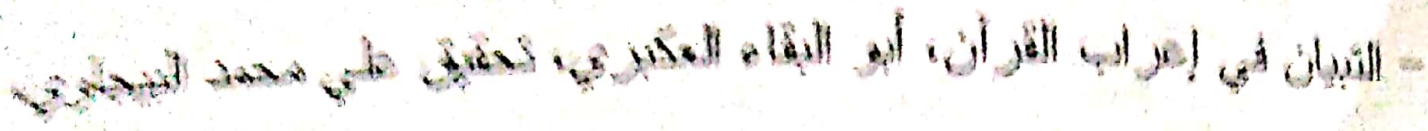

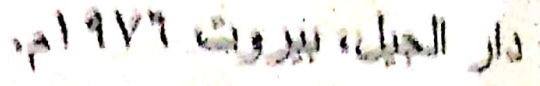

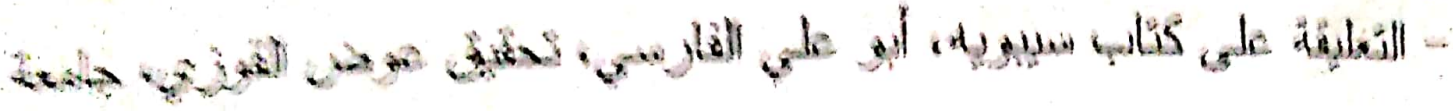

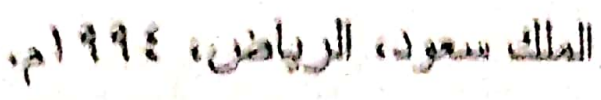

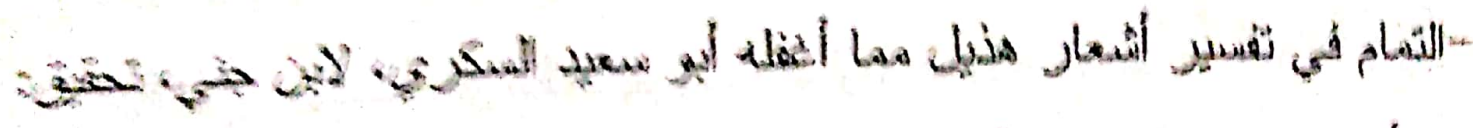

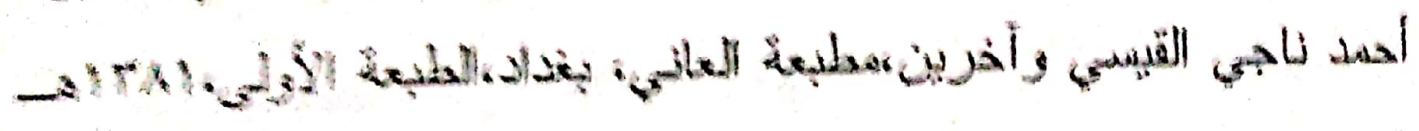
$.991 /$

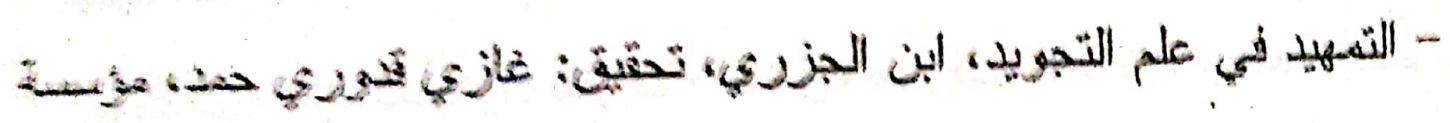

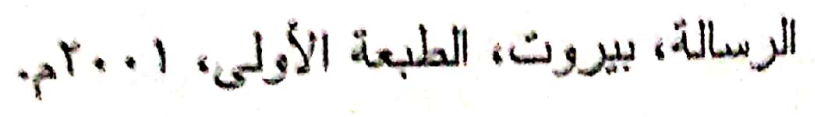

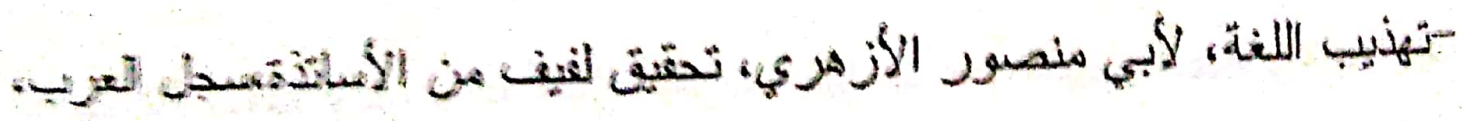
p) 977

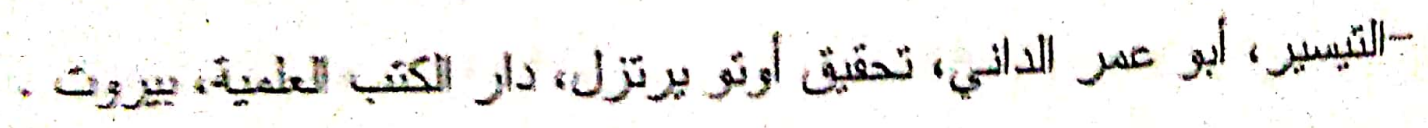
. 1997

- الجاهع لاحكام القرأن، القرطبي، دلر الكتب العلمية، بيروث. 19ra - جمهرة اللغة، لابن دربد، دار مسار، بيروت. 


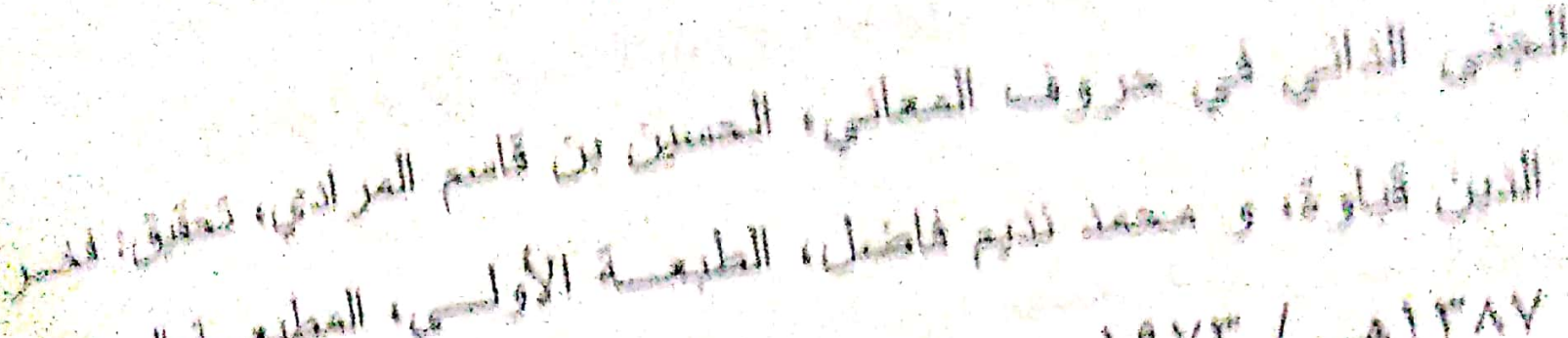

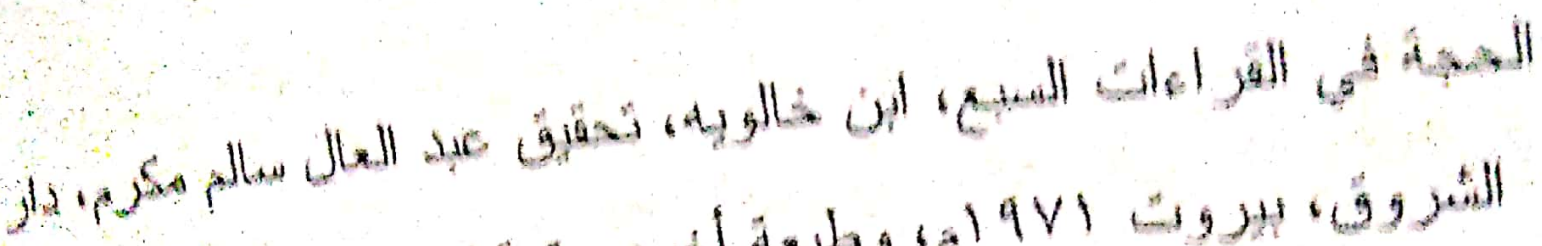

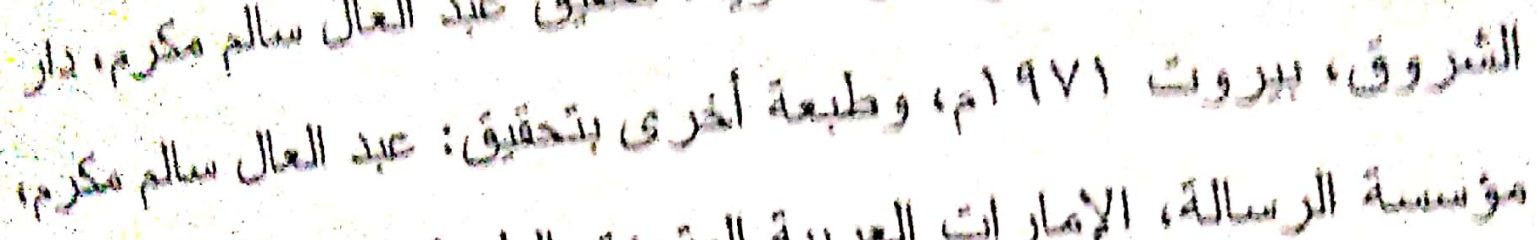

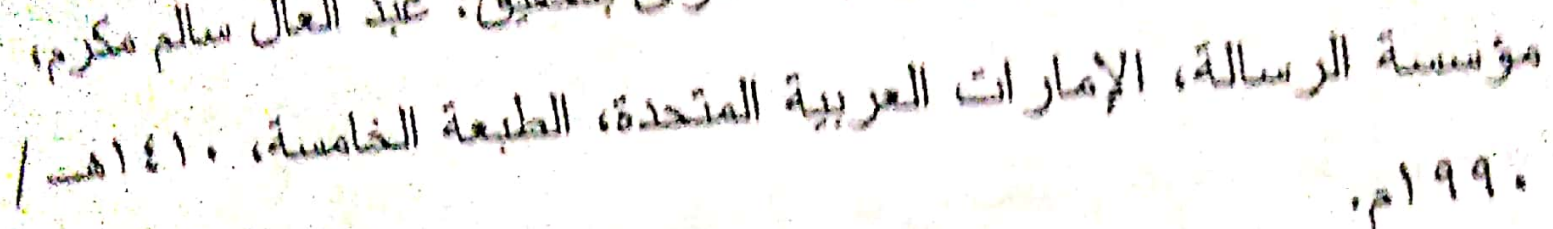
-

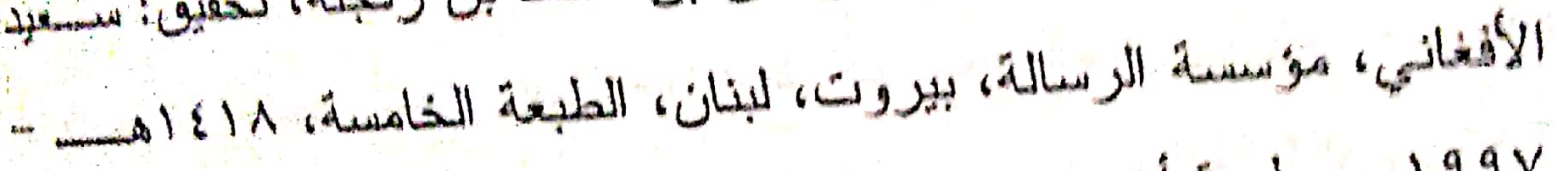
م 9V9 9 9V 99

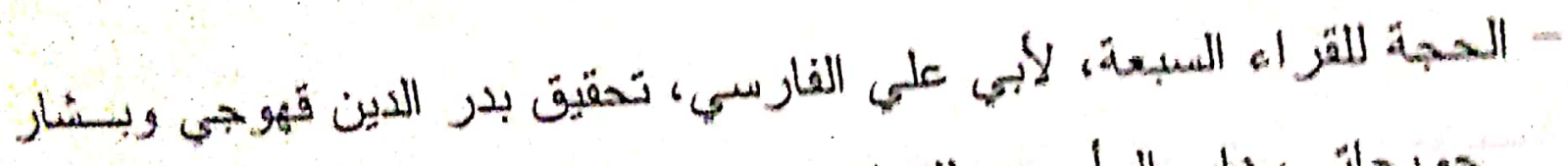

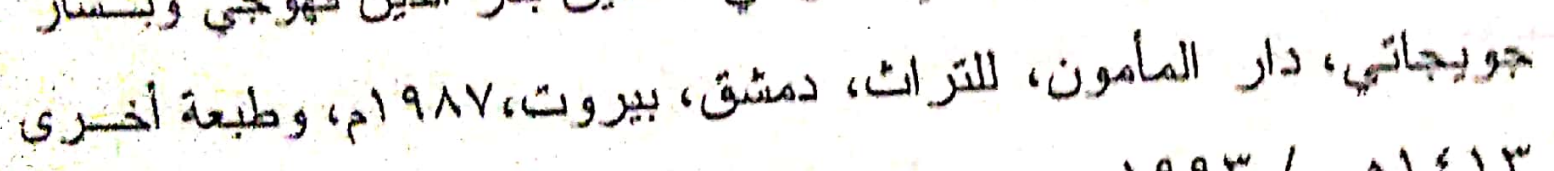

$$
\text { . } 1994 /-8151 r
$$

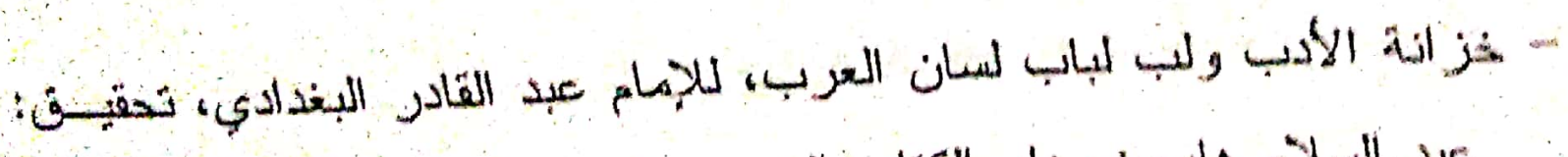

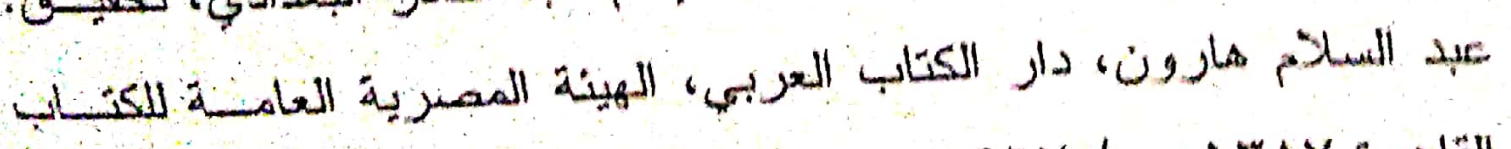

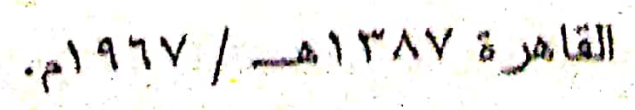

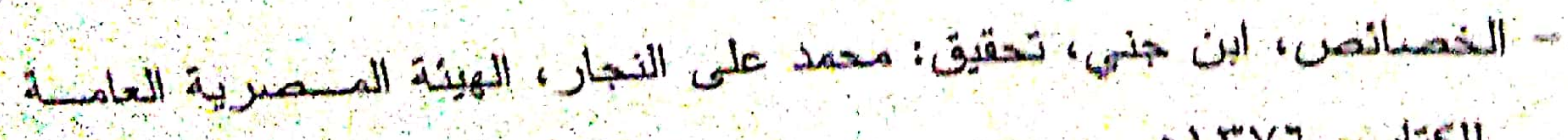

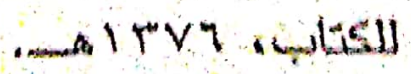

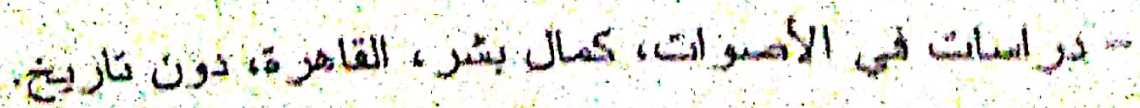




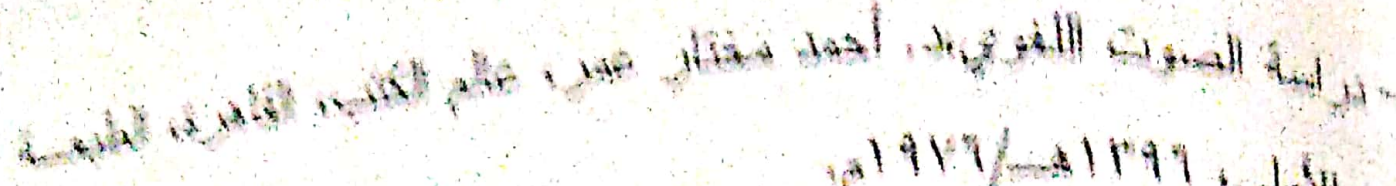
$491 / \infty 1+91,601$

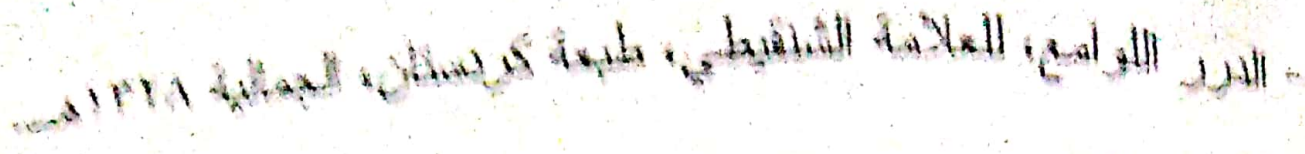

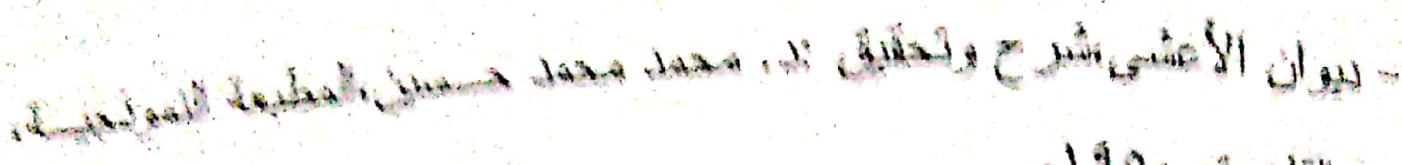
i 190,3 , still

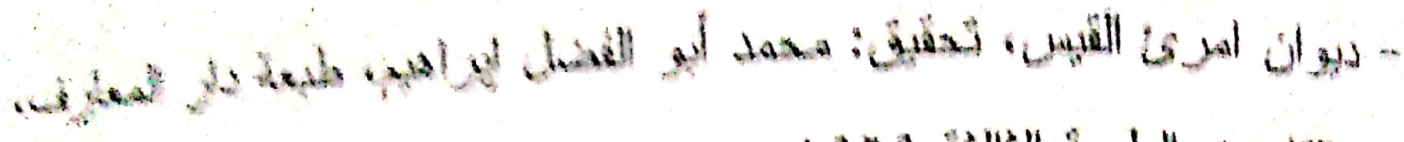

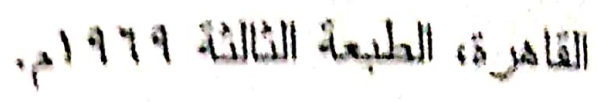

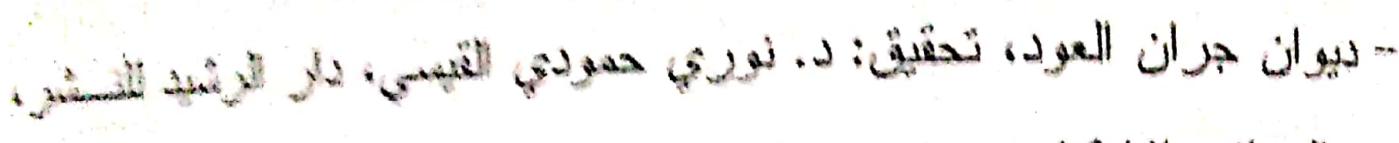

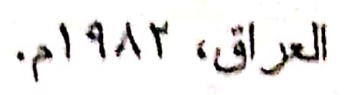

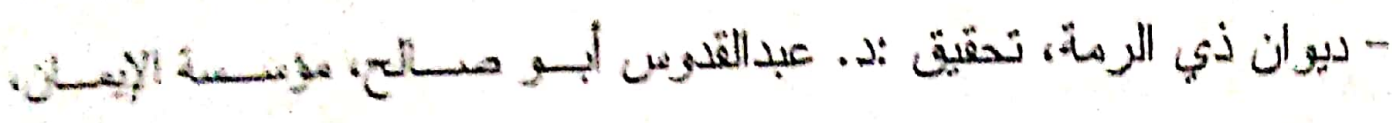

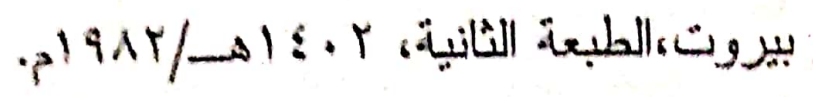

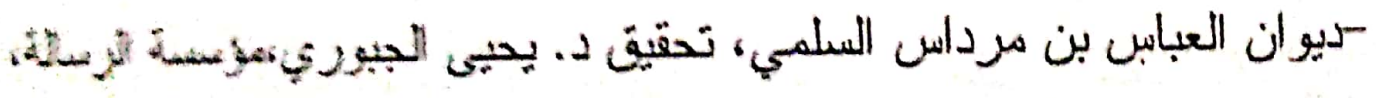

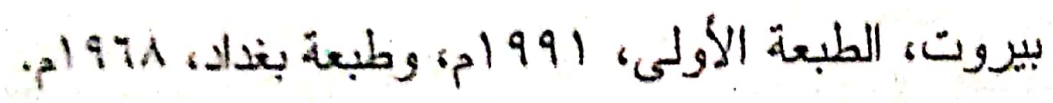

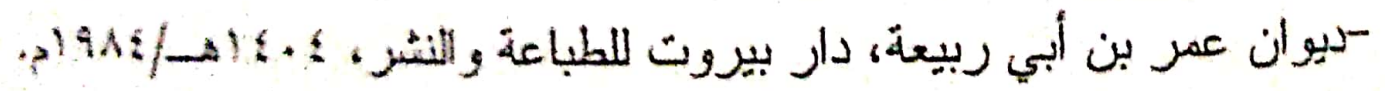

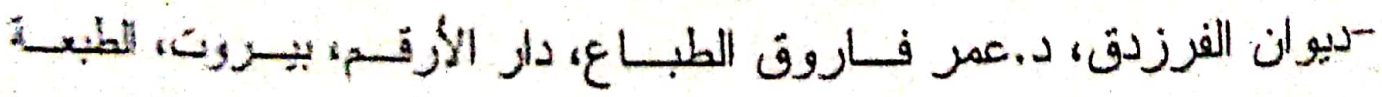

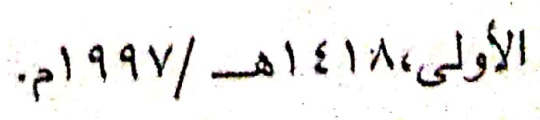

-ديوان مجنون اليلى، تحقيق: عبدالستار أحمد فراج، دار مجر المطباعـةندون تاريخ 


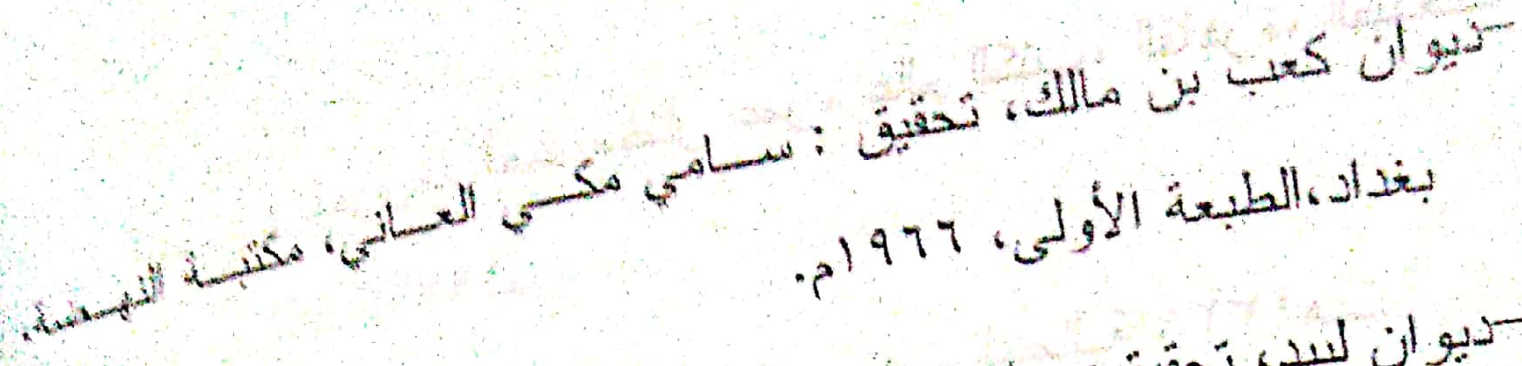

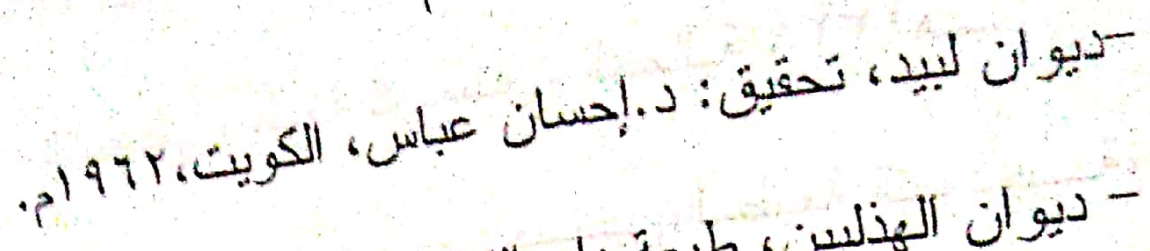

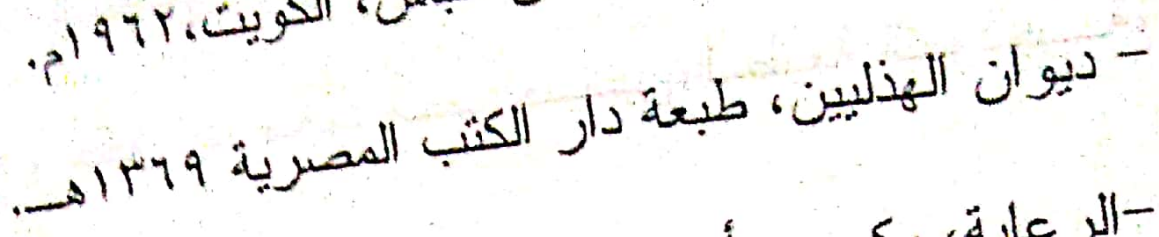
-الر عاية، مكي بن أبي طالب القيسي، نحقيق أحمد حسن فرحات، دلر عمسر. - السبعة، ابن مجاهد، تحقيق: شوفي ضيف، دار المعارف، القاهرة، الطبعـة

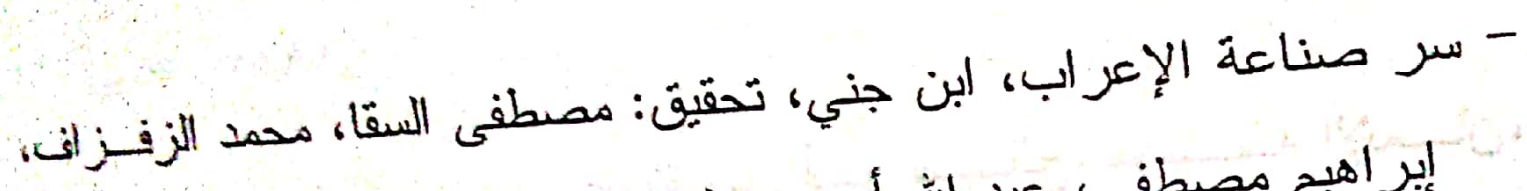

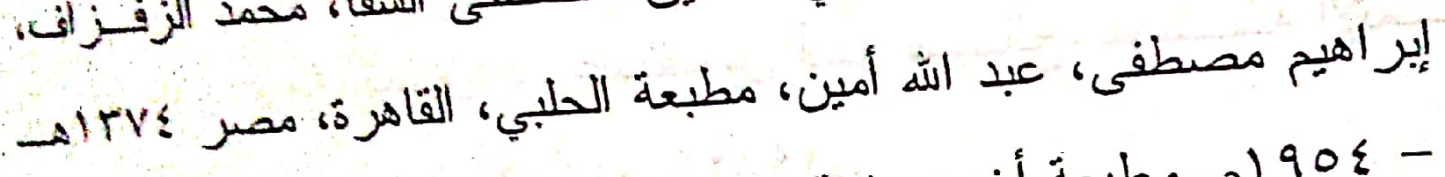

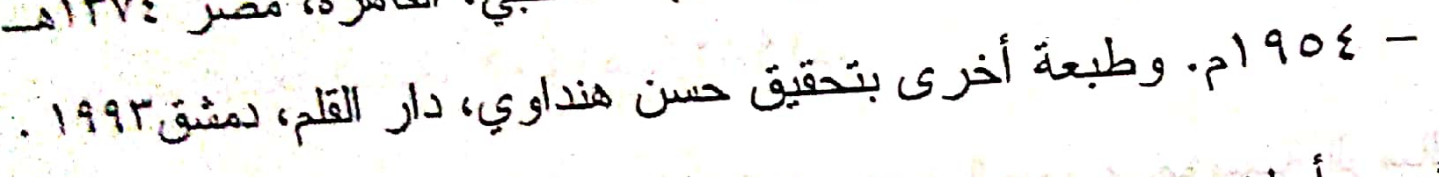
- شرح أبيات سيبويه، يوسف بن المرزبان النير افي تحقيق :محمـد الـريح

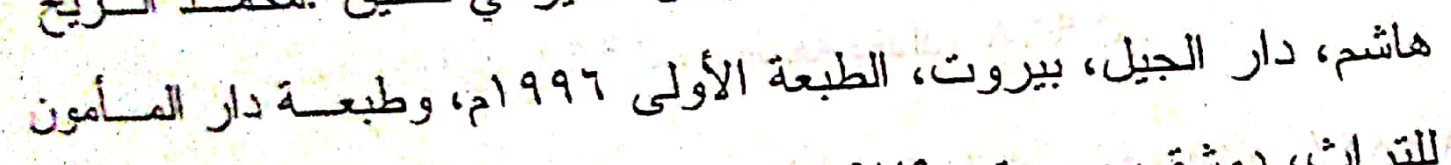

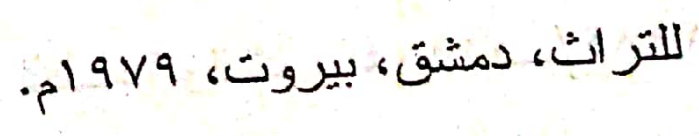

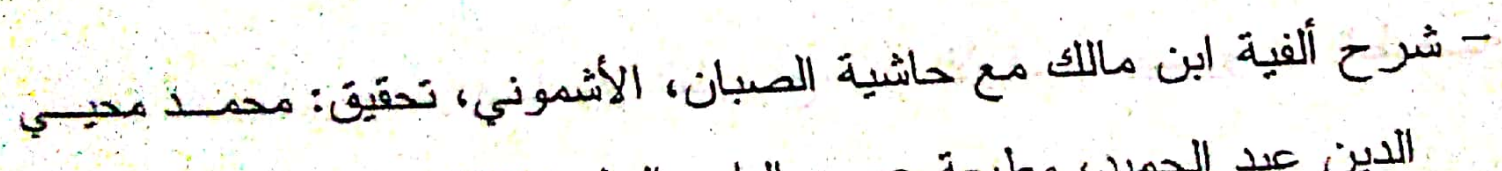

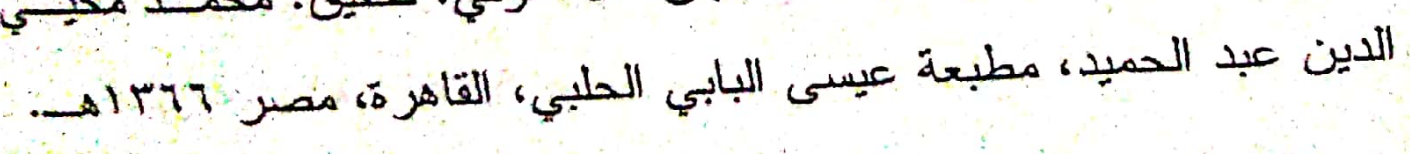
- شرح الدرر اللوامع في أهل مقر الإمام نافع أبو عبد الهه محمد بـن عبــ

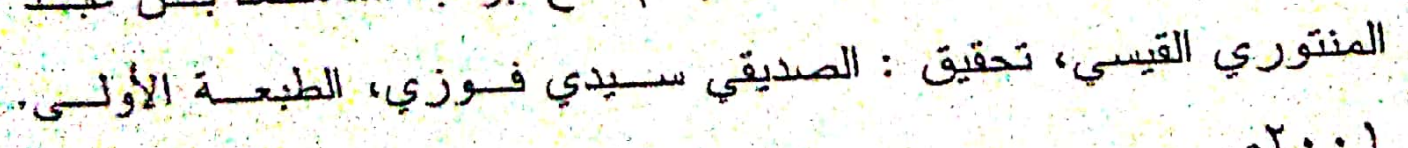

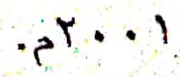




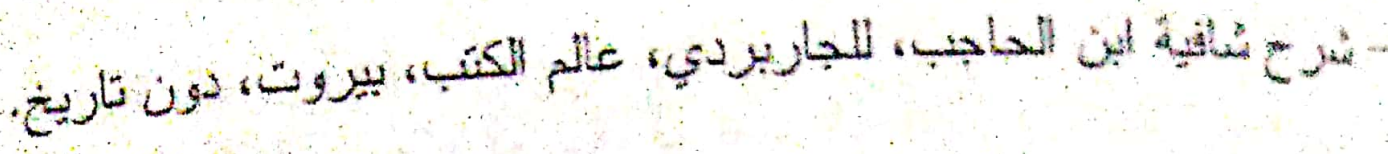

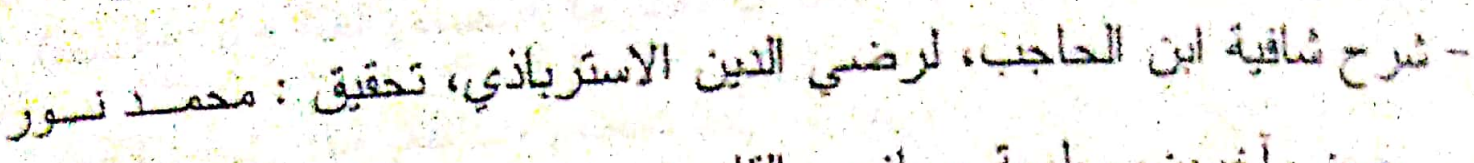
كسن و أخرين، مطبعة حجازي، القاهرة.

- شرح شواهد المغني، لجلال الدين السيوطي، تصديح: محمود السشنفيطي، تعليق: أحمد ظافر كوجان، طبعة لجنة الثراث العربي، دمشق، سوريا.

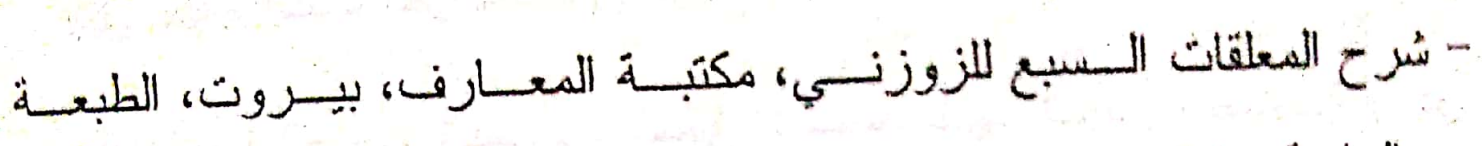

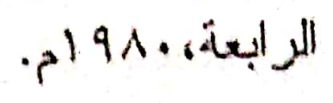

- شرح المفصل، لموفت الدين بن بعيش، تحقيق الأستاذ: محمد منير، المطبعة

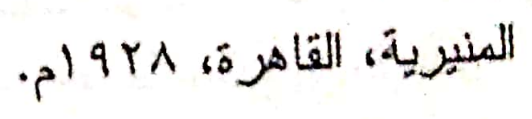

- شر ح المفصل في صنعة الإعر اب الموسوم بالتخمير ، القاسم بن حسين

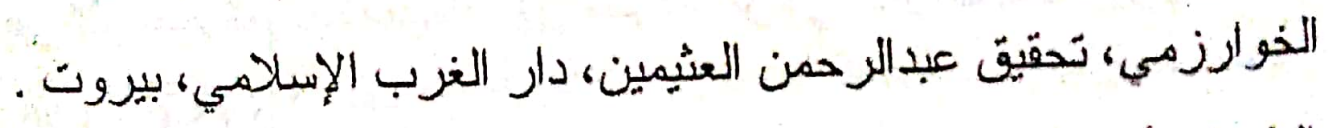
الطبعة الأولى، • 199 م.

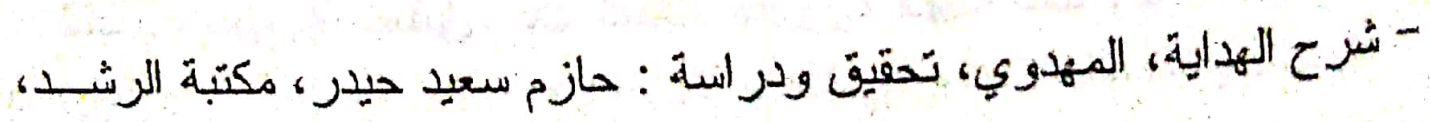
الرياض، الطبعة الأولى، 1990م. 190.

سُعر إيز اهيم بن هزمة، تحقيق محمد نفاغ وآخر، مطبو عات مجمـع اللغــة العبية بذمشق.

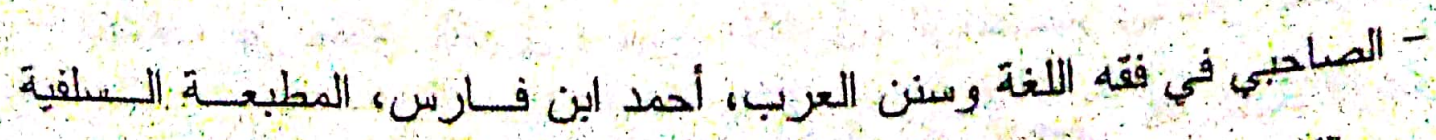
بالقاهرة: 


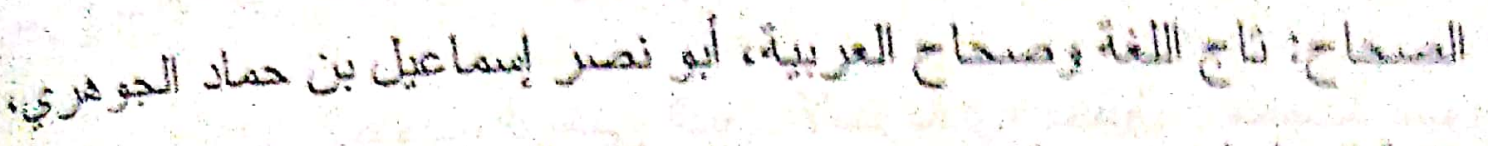

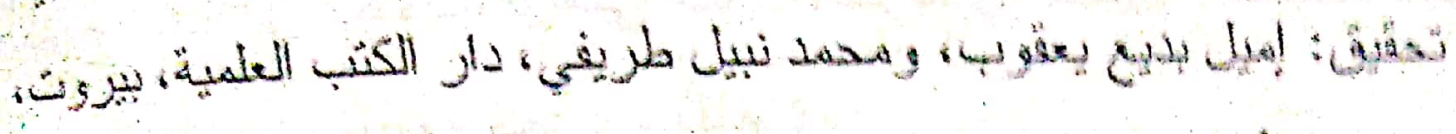

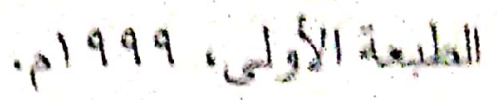

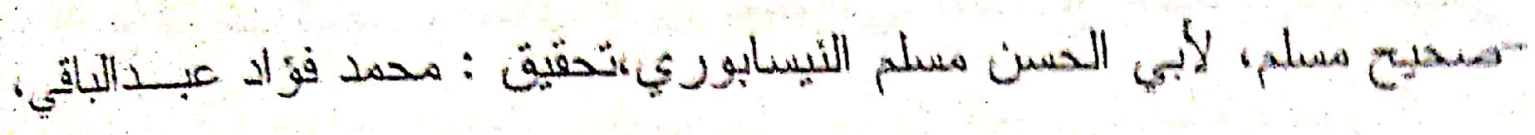
دار إحباء الكنب العربية، دون ثناريخ.

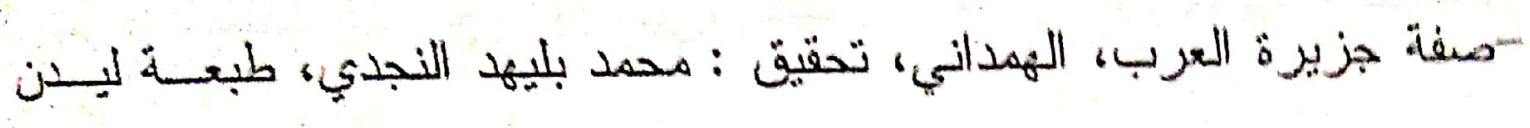
وملبعة القاهرة.

-- في صوتيات العربية، محيي الدين رمضان، مكتبة الرسالة الحديثة، عمسنان، - $) 19 \vee 9$

- في اللهجات العربية القديمة، إير اهيم الساهر ائي، دار الحداثة، بيروت، الطبعة الأولى، و 99 ام.

- الكتاب، سيبويه، تحقيق: عبد السلام هارون، الهيئة المصرية العامة للكتاب $.019 \wedge r$

- الكتاب الموضح في وجوه القر اعات و عللها، ابن أبي مريم، تحفيق عمر حمدان.

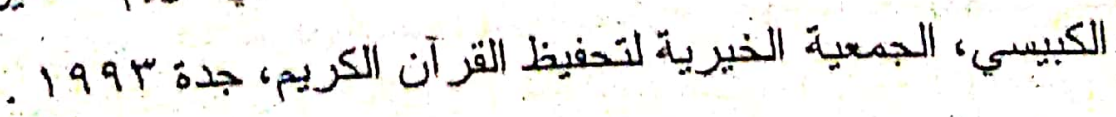

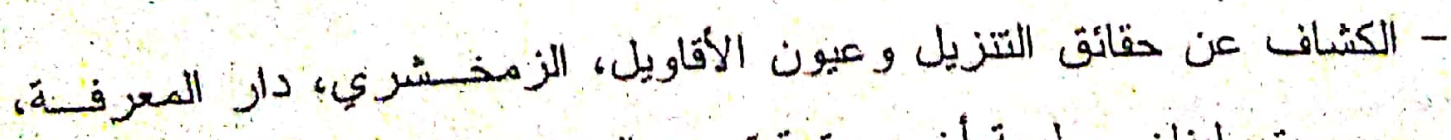

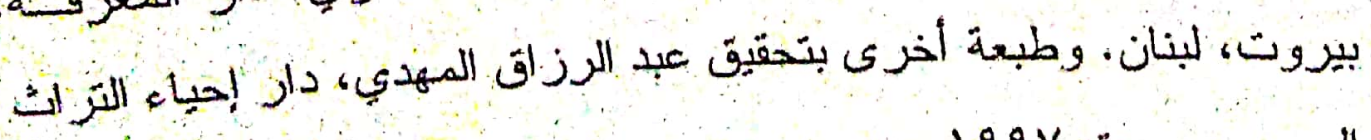

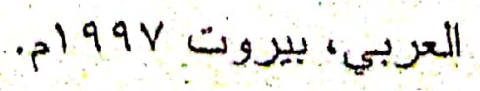




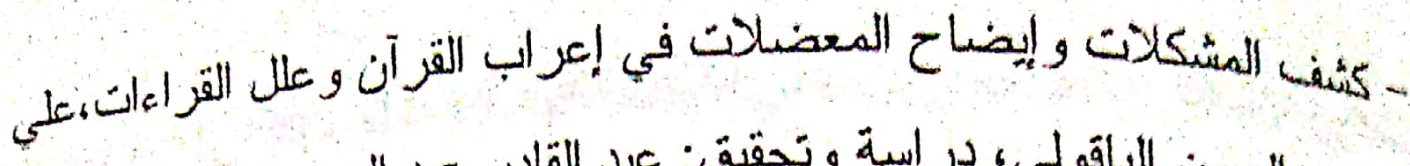
بن الحسن الباقولي، دراسة وتحقيق: عبد القادر عبد الرحمن السسعدي، دار

$$
\text { عهار ، الأردن، الطبعة الأولى، ( +. بام. }
$$

- سبان العرب، ابن منظور، تحقيق: يوسف خياط، وآخر، بيروت.

ـاكغة تصيم: دراسة تاريخية وصفية، ضاحي عبد الباقي، مجمع اللغة العربيسة،

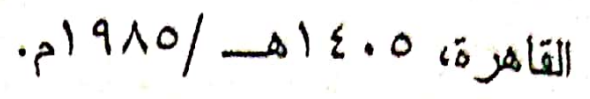

-اللهجات العربية في التزاث، أحمد علم الدين الجندي، القاهرة 1970. - اللهجات في الكتاب لسيبويه أصواتًا وبنيةً، صالحة آل غنيم، معهة البحسبوث العلمية، بيروت، الطبعة الأولى.

- المحتسب في القراءات الشاذة و عللها، ابن جني، تحقيـقق: علـي النجــي

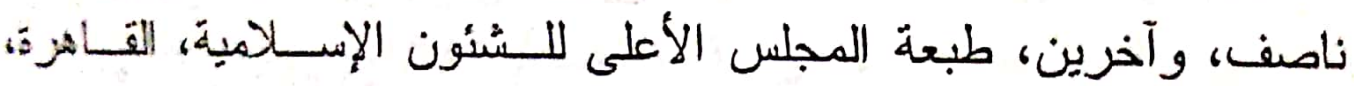
- $1 \varepsilon 10$

-المحكم و المحيط الأعظم في اللغة، لابن سيده، تحقيق د. عائشة عبدالزحن، مطبعة الحلبي، مصر، الطبعة الثالثة، 90 ام. - مختصر التصريف الملوكي، ابن جني، المطابع الأزهرية، القاهزة، بــون تاريخ.

- مختصر في شو اذ القزآن من كتاب البديع، ابن خالويه، عنـي بنسشره ج. برجشتر اسر، دار الهجرة، مصر ، بدون تاريخ. - المخصص، لابن سيدهاردار الفكر، بيروت، $9 v 1$ م. 
- المز هر في علوم اللغة و آدابها، السيوطي، تحفيق: محدد أبو الفضل إبراهبه،

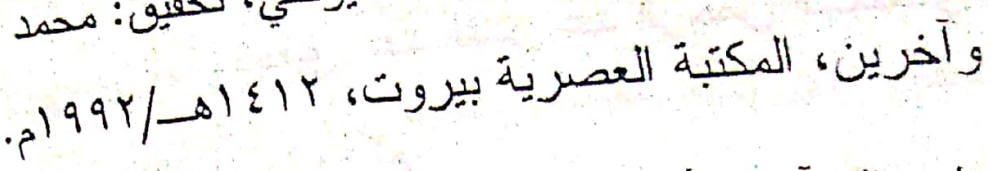

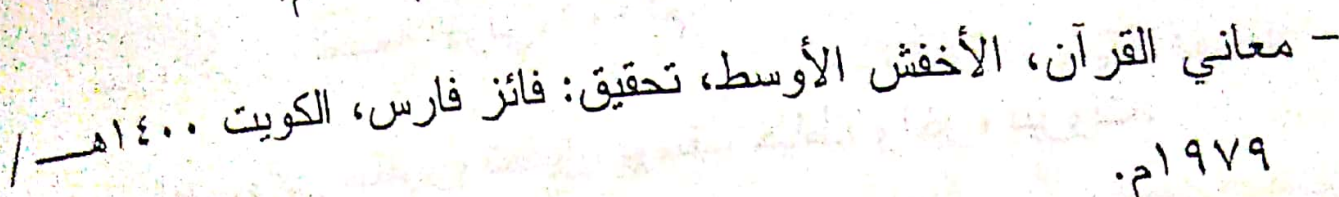
- العين، الخليل بن أحمد الفر اهيدي، تحفيق : عبداله درويش، مطبعة العساني، بغداد، $97 V$

- معجم قبائل العرب القديمة و الحديثة، محمد رضا كحالة، مؤسسة الرسالة، بيروث، الطبعة الخامسة، 910 ام. - المفصل، الزمخشري، دار الكتب العمية، بيروت. - مقاييس اللغة، ابن فارس، تحقيق: عبد السلام هــارون، دار إحبــاء الكنـبـ

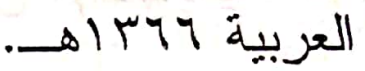

- مغني اللبيب، ابن هشام الأنصاري، تحقيق : محمد محي الدين عبد الحميذ، مطبعة المدني، القاهرة.

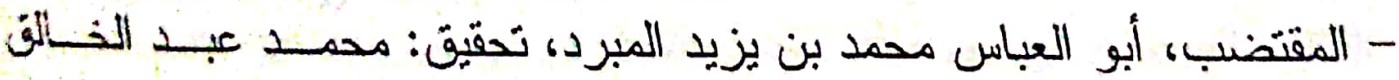

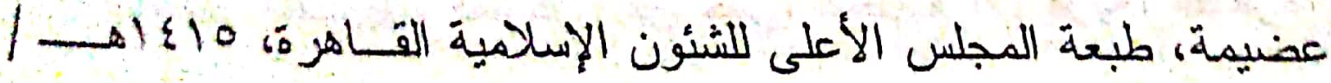
- $199 \leq$

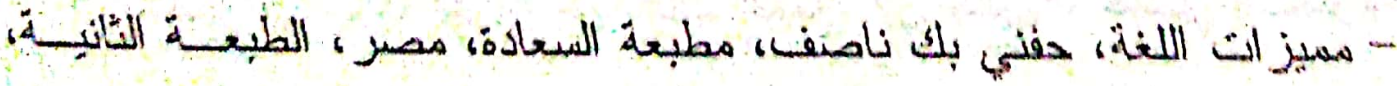
.

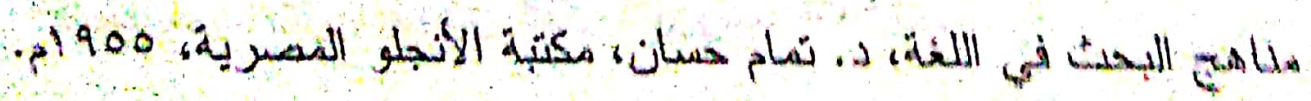
00. 


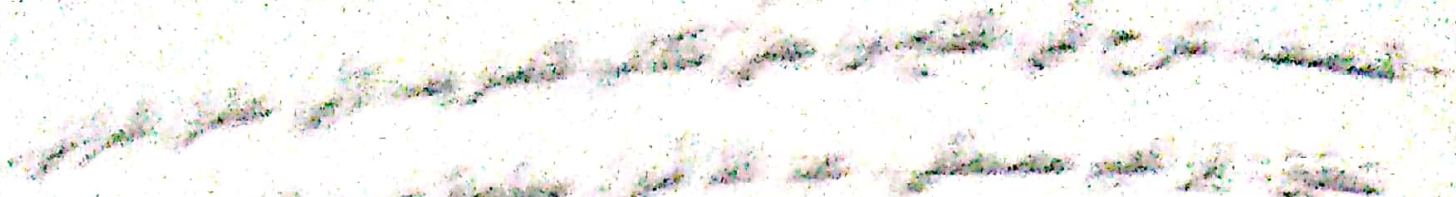

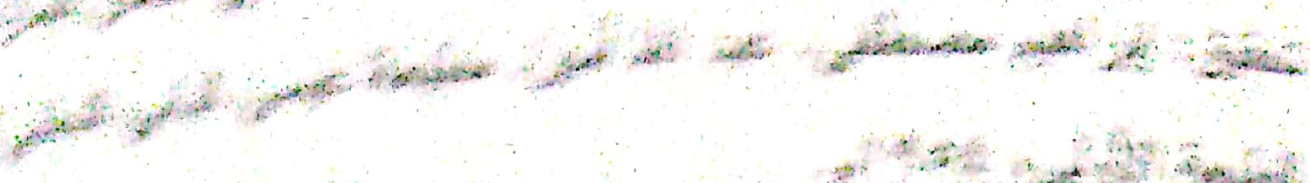

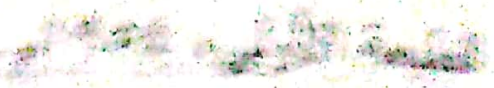

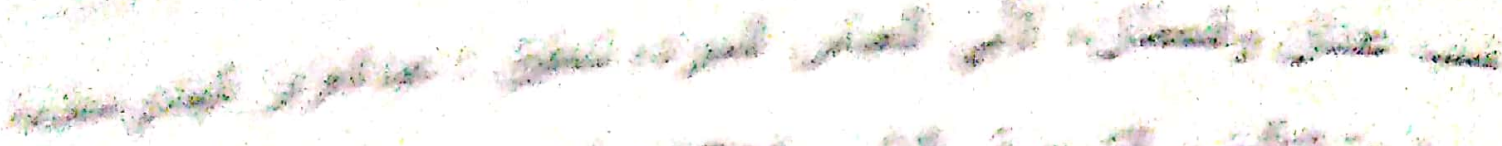

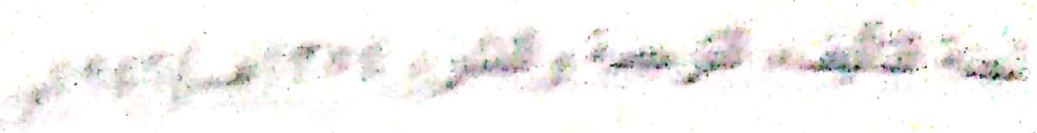

P.

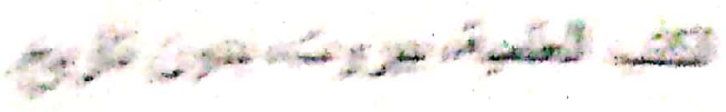

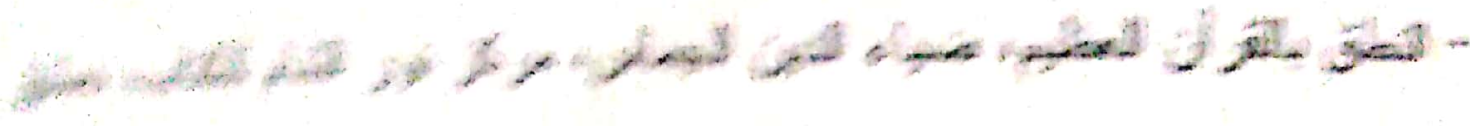

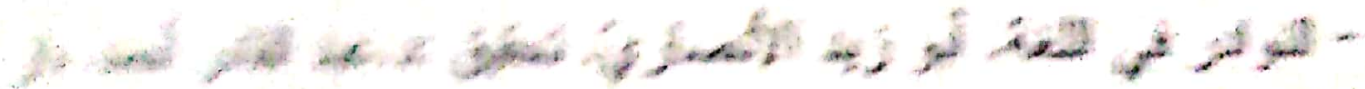

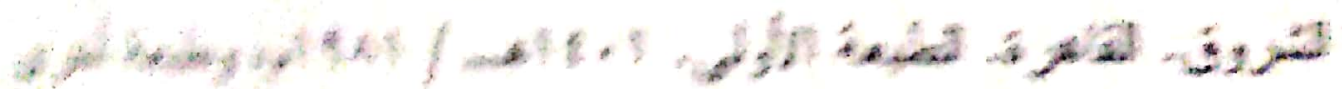

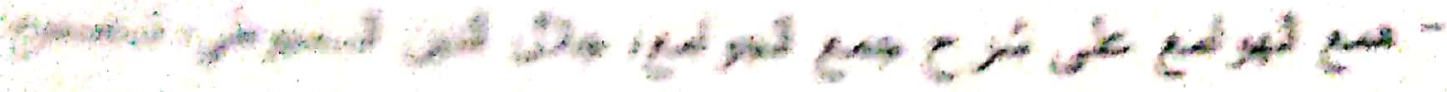

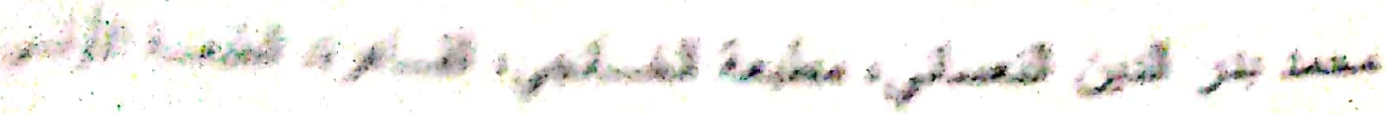

$$
p^{84+4} /+4+4 x^{4}
$$

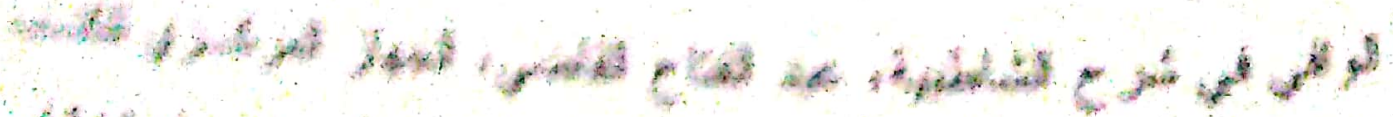

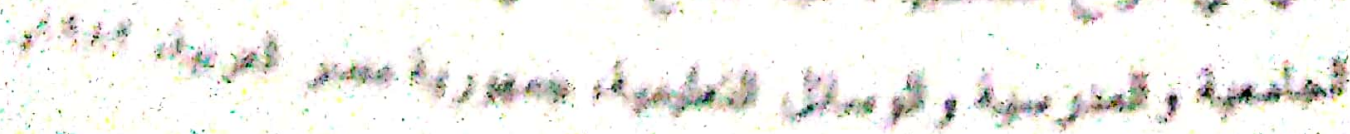

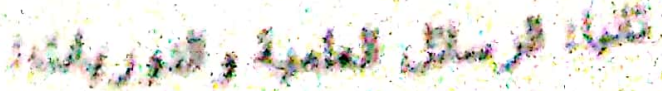

663 
--البساطة و التركيب في النحو العربي، لابر اهيم محمد خفاجة، رسالة دكتر اه، كلية دار العلوم، جامعة القاهرة، 7 × . بم.

- سيبويه و القراءات، أحمد مكي الأنصاري، مجلة مجمع اللغة العربية، الجزء،

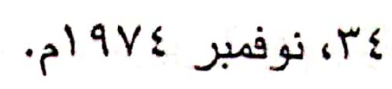

- الهزةة بين القراء و النحاة: أكرم حمدان، مجلة الجامعة الإسلامية بغزة المجلا

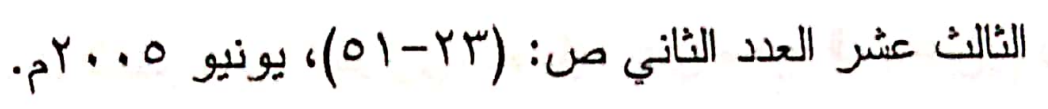

